\title{
Trace Metals in Groundwater and Vadose Zone Calcite: In Situ Containment and Stabilization of Stronthium-90 and Other Divalent Metals and Radionuclides at Arid Western DOE Sites
}

Final Report for Award Number DE-FG07-02ER63486 to the University of Idaho (RW Smith) Environmental Management Science Program Project Number 87016

November 2007

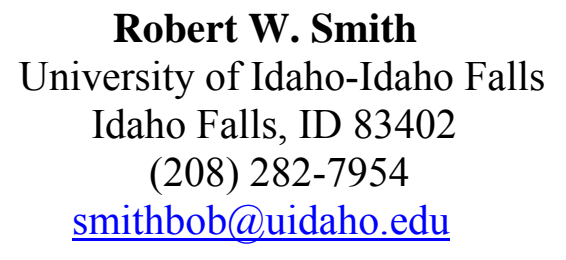

Robert W. Smith

daho Falls, ID 83402

(208) 282-7954

(a) uidaho.edu

\author{
Yoshiko Fujita \\ Idaho National Laboratory \\ Idaho Falls, ID 83415 \\ (208) 526-1242 \\ Yoshiko.Fujita@,inl.gov
}

Special thanks to Mikala Beig and Joanna Taylor for preparation of this report. 


\title{
EXECUTIVE SUMMARY
}

\section{Trace Metals in Groundwater and Vadose Zone Calcite: In Situ Containment and Stabilization of Stronthium-90 and Other Divalent Metals and Radionuclides at Arid Western DOE Sites}

\author{
Final Report for Award Number DE-FG07-02ER63486 to the University of Idaho (RW \\ Smith) Environmental Management Science Program Project Number 87016
}

\author{
Robert W. Smith and Yoshiko Fujita
}

November 2007

\begin{abstract}
Radionuclide and metal contaminants are present in the vadose zone and groundwater throughout the U.S. Department of Energy (DOE) energy research and weapons complex. In situ containment and stabilization of these contaminants represents a cost-effective treatment strategy that minimizes workers' exposure to hazardous substances, does not require removal or transport of contaminants, and generally does not generate a secondary waste stream. We have investigated an in situ bioremediation approach that immobilizes radionuclides or contaminant metals (e.g. ${ }^{90} \mathrm{Sr}$ ) by their microbially facilitated co-precipitation with calcium carbonate in groundwater and vadose zone systems. Calcite, a common mineral in many aquifers and vadose zones in the arid west, can incorporate divalent metals such as strontium, cadmium, lead, and cobalt into its crystal structure by the formation of a solid solution. Collaborative research undertaken by the Idaho National Laboratory (INL), University of Idaho, and University of Toronto as part of this Environmental Management Science Program project has focused on in situ microbially-catalyzed urea hydrolysis, which results in an increase in $\mathrm{pH}$, carbonate alkalinity, ammonium, calcite precipitation, and co-precipitation of divalent cations. The activities conducted by researchers at the University of Toronto are described in a separate DOE final report submitted by Grant Ferris in 2003 (http://www.osti.gov/bridge/product.biblio.jsp?query id=2\&page=0\&osti_id=809819). In calcite-saturated aquifers, microbially facilitated co-precipitation with calcium carbonate represents a potential long-term contaminant sequestration mechanism. The specific objectives of the research were:
\end{abstract}

- Elucidation of the mechanisms and rates for the release of sorbed trace metals and their subsequent sequestration by co-precipitation in calcite induced by urea hydrolysis.

- Evaluation at the field scale of the influence of microbial calcite precipitation on the partitioning and retention of strontium and other naturally occurring divalent metals in groundwater.

- Identification of specific microbial characteristics that signify subsurface geochemical conditions conducive to calcite precipitation. 
Key results of the project include:

- Demonstrating the linkage between urea hydrolysis and calcite precipitation in field and laboratory experiments (Fujita et al., in review; Colwell et al., 2005, Appendix A; Ferris et al., 2004, Appendix B; Fujita et al., 2004, Appendix C).

- Observing strontium incorporation into calcite precipitate by urea hydrolyzers with higher distribution coefficient than in abiotic system (Fujita et al., 2004, Appendix C; Mitchell and Ferris, 2005).

- Developing and applying molecular methods for characterizing microbial urease activity in groundwater including a quantitative PCR method for enumerating ureolytic bacteria (Gresham et al., 2007, Appendix D; Petzke, 2006).

- Applying the suite of developed molecular methods to assess the feasibility of the proposed bioremediation technique at a contaminated site located within the $100-\mathrm{N}$ area of the Hanford, Washington site (Fujita et al., in prep, Appendix E).

- Assessing the role of nitrification on the persistence of precipitated calcite by modifying primers for identification of the amoA gene region of various ammonia oxidizing bacteria (AOB) for characterizing AOB in the field (Freeman et al., 2006, Appendix F).

The UP-1 field experiment (Fujita et al., in review) described in the body of this summary represents the application of the knowledge gained and tools developed during the entire course of the project. Numerous appendices provide details of the individual laboratory and field experiments that led up to the field experiment described below. We also applied the molecular tools developed during the course of the project to assess the feasibility of the proposed bioremediation technique at a contaminated site. These activities are detailed in Appendix E.

The results we obtained from the studies outlined below and those described in the appendices indicate that bioremediation of radionuclide or divalent metals is a viable remediation approach. During the UP-1 field experiment, sequential addition of molasses and urea was tested as a means of stimulating microbial urea hydrolysis in the Eastern Snake River Plain Aquifer in Idaho. In this single-well experiment, dilute molasses was injected on three separate occasions over a period of two weeks to promote overall microbial growth, followed by a single urea injection. With molasses addition, total cell numbers in the groundwater increased one to two orders of magnitude. Estimated ureolysis rates in recovered groundwater samples increased from $<0.1 \mathrm{nmol} \mathrm{L}^{-1} \mathrm{hr}^{-1}$ to $>25 \mathrm{nmol} \mathrm{L}^{-1} \mathrm{hr}^{-1}$. A quantitative PCR assay for the bacterial ureC gene indicated that urease gene numbers increased up to 170 times above pre-injection levels. Following urea injection, calcite precipitates were recovered. Estimated values for an in situ first order ureolysis rate constant ranged from 0.016 to 0.057 day $^{-1}$. The results are promising with respect to the potential to manipulate in situ biogeochemical processes to promote contaminant sequestration. 


\section{TABLE OF CONTENTS}

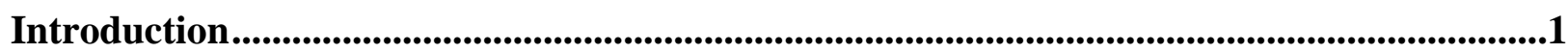

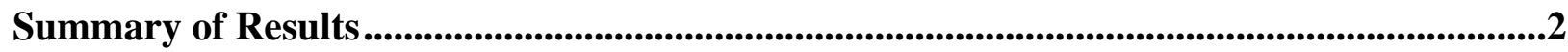

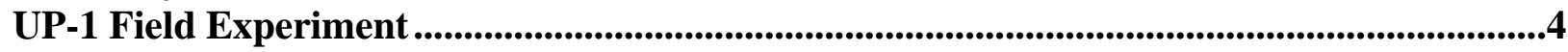

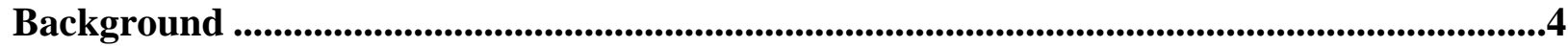

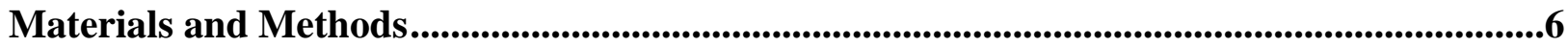

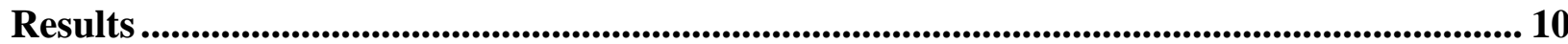

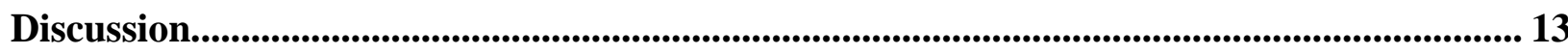

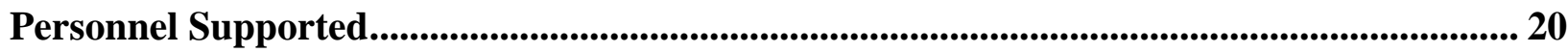

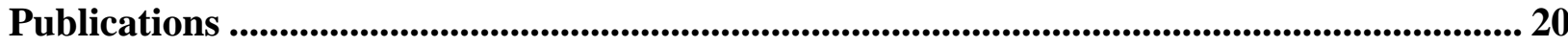

Presentations ...................................................................................................................................... 22

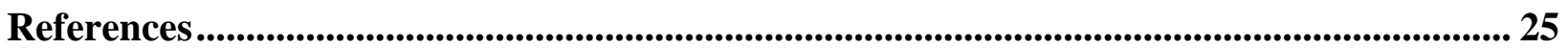

Appendices

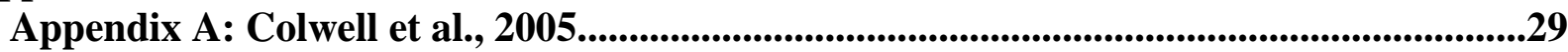

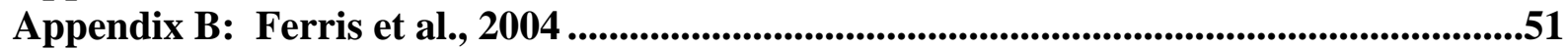

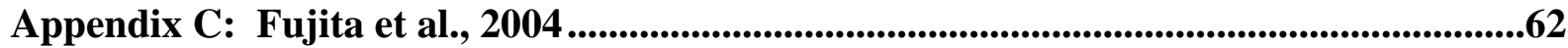

Appendix D: Gresham et al., 2007....................................................................................73

Appendix E: Fujita et al., in prep...........................................................................................86

Appendix F: Freeman et al., 2006............................................................................................93 


\section{Trace Metals in Groundwater and Vadose Zone Calcite: In Situ Containment and Stabilization of Stronthium-90 and Other Divalent Metals and Radionuclides at Arid Western DOE Sites}

\section{Introduction}

The U.S. Department of Energy (DOE) is committed to aggressively cleaning up the environmental legacy of nuclear weapon and civilian nuclear research and development programs at 132 sites throughout the United States (DOE 2000). In total, these sites represent large volumes of contaminated media with reoccurring contaminants (Riley and Zachara, 1992). To meet the DOE cleanup challenge, better remediation technologies, long term stewardship options, and alternate cleanup approaches are required. One approach that is growing in acceptance by DOE and regulators is in situ Containment and Stabilization (NRC 2000). In situ containment and stabilization have inherent advantages because they are less costly than the removal, transport, and disposal of contamination. This approach also minimizes worker exposure because contaminated materials are not brought to the surface. In addition, containment and stabilization will minimize the generation of secondary waste streams with their associated treatment and disposal costs. Finally, containment and stabilization are generally more protective of the public and the environment because the small on-site footprint minimizes collateral environmental damage and minimizes offsite risks such as transportation. In many cases, containment and stabilization will serve as a long-term solution (e.g., for short lived isotopes such as ${ }^{60} \mathrm{Co},{ }^{137} \mathrm{Cs}$, or ${ }^{90} \mathrm{Sr}$ ). In other cases, containment and stabilization will be an interim solution (such as capping or grouting leaks at mixed waste landfills) that provides immediate environmental protection and allows time for the development of technologies required for permanent solutions.

The focus of the research reported here was to investigate the in situ stabilization and containment of radionuclides or contaminant metals (e.g., ${ }^{90} \mathrm{Sr}$ ) by their facilitated coprecipitation with calcium carbonate in groundwater and vadose zone systems. Our facilitated approach, shown schematically in Figure 1, relies upon the hydrolysis of introduced urea to cause the acceleration of calcium carbonate precipitation (and trace metal co-precipitation) by increasing groundwater $\mathrm{pH}$ and alkalinity. Subsurface urea hydrolysis is catalyzed by the urease enzyme, which may be either introduced with the urea or produced in situ by ubiquitous subsurface urea hydrolyzing microorganisms. Because the precipitation processes are irreversible and many western aquifers are saturated with respect to calcite, the co-precipitated metals and radionuclides will be effectively removed from groundwater. Another advantage of the ureolysis approach is that the ammonium ions produced by the reaction can exchange with radionuclides sorbed to subsurface minerals, thereby enhancing the susceptibility of the radionuclides for re-capture in a more stable solid phase (co-precipitation rather than adsorption). Our specific research objectives include

- Elucidation of the mechanisms and rates for the release of sorbed trace metals and their subsequent sequestration by co-precipitation in calcite induced by urea hydrolysis.

- Evaluation at the field scale of the influence of microbial calcite precipitation on the partitioning and retention of strontium and other naturally occurring divalent metals in groundwater. 
- Identification of specific microbial characteristics that signify subsurface geochemical conditions conducive to calcite precipitation.

These objectives were address by conducting integrated field and laboratory research evaluating (a) the precipitation rate of calcite through in situ experiments and (b) the partitioning of strontium and other metals into carbonate minerals through laboratory experiments and field characterization. Sites selected for the field-based research include an uncontaminated basaltic aquifer with hydogeological features similar to the ${ }^{90} \mathrm{Sr}$ contaminated groundwater site at the Idaho Nuclear Technology and Engineering Center (INTEC) of the Idaho National Laboratory. In addition the characterization tools developed were applied to core and water samples collected from the ${ }^{90} \mathrm{Sr}$ contaminated $100-\mathrm{N}$ area of the Hanford Reservation located in Southeast Washington State.

\section{Summary of Results}

Demonstrating the linkage between urea hydrolysis and calcite precipitation in field and laboratory experiments (Fujita et al. in review, Colwell et al., 2005, Appendix A; Ferris et al., 2004, Appendix B; Fujita et al., 2004, Appendix C). - Laboratory experiments using pure cultures of Sporosarcina pasteurii, a known urea hydrolyzer, have yielded kinetic expressions that couple the hydrolysis of urea with the precipitation of calcite over a temperature range (10 to $20 \mathrm{C})$ relevant to groundwater conditions. These results showed a 10 fold increase in the firstorder rate constant for urea hydrolysis over the temperature range investigated. However, no temperature dependence was observed over the range of investigation for the rate constant of the second-order chemical affinity based expression describing calcite precipitation (Ferris et al., 2004). Calcite precipitation via urea hydrolysis has also been demonstrated in a field setting. In a single-well push pull test conducted in the Snake River Plain aquifer, the injection of low levels of molasses $\left(7.5 \mathrm{mg} \mathrm{L}^{-1}\right)$ increased the in situ urea hydrolysis rate by a factor of 270 . Subsequent injection of mmolar levels of urea resulted in the precipitation of calcite (Fujita et al., in review).

Observing strontium incorporation into calcite precipitate by urea hydrolyzers with higher distribution coefficient than in abiotic system (Fujita et al., 2004, Appendix C; Mitchell and Ferris, 2005). - Batch laboratory experiments using S. pasteurii yielded distributions coefficients for strontium in calcite that were significantly higher than those obtained for 
ammonium carbonate controls. Time-of-Flight Secondary Ion Mass Spectrometry and X-ray absorption spectroscopy analyses were both consistent with the presence of strontium in the calcite as a solid solution. Our results suggest that observed differences between the S. pasteurii precipitated calcites and calcites precipitated in the control experiments are the result of differences in the precipitation rate.

Developing and applying molecular methods for characterizing microbial urease activity in groundwater including a quantitative PCR method for enumerating ureolytic bacteria (Gresham et al., 2007, Appendix D; Petzke, 2006). - Urease-specific polymerase chain reaction (PCR) primers designed to amplify ureC, a gene that codes for a conserved subunit of the urease enzyme, were developed to detect aquifer microbes with the ability to hydrolyze urea. Several sets of PCR oligonucleotide primers were designed based on an alignment and phylogenetic analysis of known ureC genes. The developed primers were used to determine the presence of urease genes in complex microbial communities collected from the Snake River Plain Aquifer before, during, and after the groundwater had been stimulated using molasses and urea using a single-well push-pull test. The PCR data suggest that following urea and molasses addition the urease gene target was detected more consistently and in greater abundance. The molecular tools are important for demonstrating that microbially catalyzed urea hydrolysis (and associated calcite precipitation) is occurring in situ.

Applying the suite of developed molecular methods to assess the feasibility of the proposed bioremediation technique at a contaminated site located within the 100-N area of the Hanford, Washington site (Appendix E). - In addition to applying the suite of molecular methods to the uncontaminated test area at University Place in Idaho Falls, we applied the molecular tools in an assessment of a contaminated site at the Hanford 100-N Area. The intent of the assessment was to determine if an indigenous population of ureolytic bacteria existed at the Hanford site and could be called upon to encourage the co-precipitation of ${ }^{90} \mathrm{Sr}$ with calcite. Results from MPN estimates, qPCR assay, and in situ ureolytic rate estimates indicated that ureolytic bacteria are present in the ground water in 100-N Area at Hanford and in situ ureolytic rate estimates detected activity in all sediment samples, while the qPCR assay detected ure $\mathrm{C}$ genes in 6 of 11 sediment samples for core 199-N-121 in 100-N Area at Hanford. In the interval between 17.5 and 18 feet below land surface, there was a large surge in estimated ureolytic rates and ureC genes. In situ ureolytic rate estimates were 1000x higher for the sediment samples than the ground water samples, indicating the majority of ureolytic activity is attributed to the attached communities. Therefore, our results indicated that significant microbial ureolysis activity does occur at the $100-\mathrm{N}$ Area, and that engineered calcite precipitation is a potential option for remediation.

Assessing the role of nitrification on the persistence of precipitated calcite by modifying primers for identification of the amoA gene region of various ammonia oxidizing bacteria (AOB) for characterizing AOB in the field (Freeman et al., 2006, Appendix F). - The oxidation of ammonia results in the production of $\mathrm{H}^{+}$, which can lower groundwater $\mathrm{pH}$ of groundwater resulting in the dissolution of calcium carbonates containing sequestered strontium. Because urea hydrolysis may promote the growth of AOB and nitrification with its associated acid production we modified primers for identification of the amoA gene region of various ammonia oxidizing bacteria for characterizing AOB in the field. Initial sequencing results suggest that the 
primers were successful at specific detection of amoA sequences and the RFLP analyses indicated that the diversity of detected amoA sequences in the ESRPA decreased with the additions of molasses and urea.

\section{UP-1 Field Experiment}

The UP-1 field experiment (Fujita et al., in review) described in detail below represents the application of the knowledge gained and tools developed during the entire course of the project. Numerous appendices provide details of the individual laboratory and field investigation that culminated in our understanding of the biogeochemistry of urea hyrolysis under field conditions.

\section{Background}

Deep subsurface contamination by trace metals and radionuclides is a significant challenge for the U. S. Department of Energy (NRC, 2000). Because of the enormous volumes of contaminated material and their inaccessibility in the deep subsurface, the development of cost-effective methods for in situ containment and stabilization of these pollutants is critical. Strontium-90, a uranium fission byproduct, is a contaminant at several DOE sites (Riley, 1992). Because its chemical behavior is similar to calcium, ${ }^{90} \mathrm{Sr}$ can accumulate in bone tissue, and cause cancer. As it is relatively mobile, ${ }^{90} \mathrm{Sr}$ poses a particular risk to groundwater.

Currently accepted methods for ${ }^{90} \mathrm{Sr}$ remediation in groundwater are limited. At the Hanford DOE site in Washington, concern over the discharge of ${ }^{90} \mathrm{Sr}$-contaminated groundwater into the Columbia River led to the institution of a pump and treat system in 1995 , where the ${ }^{90} \mathrm{Sr}$ laden groundwater was treated aboveground by ion exchange. However by 2003 the system was deemed "ineffective," because it removed only about $0.2 \mathrm{Ci}$ per year of ${ }^{90} \mathrm{Sr}$, approximately ten times less than the removal by natural decay (Hill, 2004). Pump and treat systems are often futile if the goal is aquifer remediation (as opposed to the provision of clean extracted water for beneficial uses), because frequently the majority of the contaminant is associated with the aquifer matrix and thus inaccessible to pumping. This is true even for mobile contaminants such as ${ }^{90} \mathrm{Sr}$. At Hanford, the pump and treat system has been discontinued, and a field study is underway to evaluate another potential remediation option - in situ remediation by sequestration in apatite (Moore, 2004). This is a promising approach and may yield dividends at Hanford. Another novel approach however that may be suitable in some environments is enhanced co-precipitation in calcite, where calcite precipitation is driven by ureolytic bacteria (Fujita et al., 2000; Fujita et al, 2004, Appendix C; Mitchell and Ferris, 2005; Warren et al., 2001). Urea hydrolysis results in the production of ammonium, bicarbonate and elevated $\mathrm{pH}$, as shown in equation (1), where urea hydrolysis is catalyzed by the enzyme urease:

$$
\mathrm{H}_{2} \mathrm{NCONH}_{2}+3 \mathrm{H}_{2} \mathrm{O} \Leftrightarrow 2 \mathrm{NH}_{4}{ }^{+}+\mathrm{HCO}_{3}{ }^{-}+\mathrm{OH}^{-}
$$

The elevated $\mathrm{pH}$ and bicarbonate promote calcite precipitation. The ammonium can exchange with $\mathrm{Sr}^{2+}$ ions (as well as $\mathrm{Ca}^{2+}$ and other cations) that reside on mineral surfaces, releasing them into the aqueous phase for reaction and subsequent redeposition in a more durable form (mineral formation vs. sorption). In environments where calcite is stable, co-precipitation in calcite represents a potential long-term sequestration mechanism for ${ }^{90} \mathrm{Sr}$. After active remediation activities to promote calcite precipitation cease and the system returns to the pre-existing 
conditions, the newly precipitated calcite will endure, and ${ }^{90} \mathrm{Sr}$ will remain immobilized. Reliance on urea hydrolysis rather than direct injection of ammonium carbonate allows the gradual in situ production and wider dissemination of the reactive (i.e., precipitation-causing) agents.

The Eastern Snake River Plain Aquifer (ESRPA) in Idaho is a basaltic aquifer that serves as the sole drinking water source for southeastern and south-central Idaho (DEQ, 2006). The water table lies typically between 50 and $300 \mathrm{~m}$ below land surface (mbls). Contamination of the aquifer by ${ }^{90} \mathrm{Sr}$ derived from uranium processing activities at the Idaho National Laboratory (INL) is a significant concern (DOE, 2006). The ESRPA is saturated with respect to calcite (Wood, 1986), and represents an environment where a calcite-based approach for immobilizing ${ }^{90} \mathrm{Sr}$ may be suitable. Moreover, although the ESRPA is known to be oligotrophic (Colwell, 1997, O'Connell, 2003, Lehman, 2004), previous research has demonstrated that ureolytic microbes are present and ureolytic bacterial isolates from the ESRPA can induce calcite precipitation in the laboratory (Fujita, 2000). The objective of the study reported here was to determine whether nutrient additions could increase ureolysis activity in the aquifer. Manipulation of the in situ ureolysis rate would likely be used as part of an engineered remediation strategy based upon this approach. Faster ureolysis could also be beneficial with respect to remediation efficiency. We have demonstrated in laboratory experiments that higher ureolysis and precipitation rates are correlated with greater partitioning of Sr into calcite solid solutions (Fujita, 2004, Appendix C; Mitchell and Ferris, 2005).

A single-well experiment was conducted to test whether adding molasses and urea sequentially would stimulate microbial ureolysis in the ESRPA. Because ureolytic activity is associated with a wide variety of prokaryotic physiologies (Mobley, 1989), the intent was to provide a general carbon substrate to promote overall growth of biomass. Molasses was selected based on previous laboratory studies of the effects of different carbon substrates (molasses, glucose, peptone, Brain Heart Infusion bacterial media) on ureolytic activity in ESRPA groundwater (Taylor, 2003). A low molasses concentration was preferred because dissolved oxygen (DO) concentrations in the ESRPA are generally near saturation (typical DO values 5 to $>10 \mathrm{mg} \mathrm{L}^{-1}$; (Knobel, 1992, Wood, 1986) and the intention was to maintain aerobic conditions. Also, organic acid production due to molasses fermentation would depress the $\mathrm{pH}$, contrary to our objective. The optimal molasses concentration was determined from a previous field experiment in which a $1 \mathrm{~g} / \mathrm{L}$ molasses solution resulted in the depletion of oxygen (Colwell, 2005, Appendix A). Through lab experiments and geochemical modeling we determined the optimal molasses concentration for stimulating the ureolytic bacteria and maintaining aerobic conditions was $7.5 \mathrm{mg} \mathrm{L}^{-1}$. (Taylor, 2003; personal communication with Bob Smith regarding unpublished modeling work).. Therefore, during the current study, a dilute molasses solution of $7.5 \mathrm{mg} \mathrm{L}^{-1}$ in groundwater was injected into the aquifer through a vertically isolated interval in a research well in Idaho Falls, ID. The molasses was injected three times over the course of two weeks, followed by a one-time injection of urea solution. Over 5 weeks, water samples were collected to assay microbial numbers, activity, and water chemistry. The results indicated that the selected nutrient amendment regime could significantly enhance ureolysis activity in the ESRPA, and empirical evidence for enhanced calcite precipitation in the aquifer was obtained. 


\section{Materials and Methods}

\section{Site Description}

The study was conducted at University Place in Idaho Falls, Idaho. Well UP-1 was used for the experiment and nutrient solutions were prepared using water extracted from UP-2, a well located $15 \mathrm{~m}$ east of UP-1. UP-1 lies approximately $215 \mathrm{~m}$ east of the Snake River. The river is perched above the regional aquifer in this reach with an estimated $37 \mathrm{~m}$ distance between the bottom of the river sediments and the top of the aquifer. The field site location is only a few minutes from both the Biogeochemistry Laboratories at the University of Idaho-Idaho Falls (UIIF) and the INL Research Center (IRC). The local lithology and well characteristics for UP-1 are presented in Figure 2. Inflatable packers were used in the open borehole $(0.20 \mathrm{~m}$ i.d. $)$ to isolate a $2.1 \mathrm{~m}$ interval of consolidated basalt, at $82.3-84.4 \mathrm{mbls}$. Downhole video logs showed no visible fractures within the interval. The water table was at 50 mbls. The regional flow direction in the vicinity of UP-1 and UP-2 is from northeast to west. Average hydraulic conductivity and porosity for the consolidated basalt were estimated to be $11 \mathrm{~m} \mathrm{~d}^{-1}$ (Gego, 2002) and 0.127 (Smith, 2001), respectively. The gradient in the vicinity of UP-1 and UP-2 is approximately 0.002 resulting in an estimated flow velocity of approximately $0.2 \mathrm{~m} \mathrm{~d}^{-1}$ for the experimental interval. However, based on field studies at multiple sites within the aquifer, hydraulic conductivity for consolidated basalts in the ESRPA varies from 1 to $1,000 \mathrm{~m} \mathrm{~d}^{-1}$ (Gego, 2002).

Gravity was used to inject all test solutions, with the injection rate controlled using a valve connected to the siphon hose. Total volumes of pumped and injected fluids were monitored with a flowmeter.

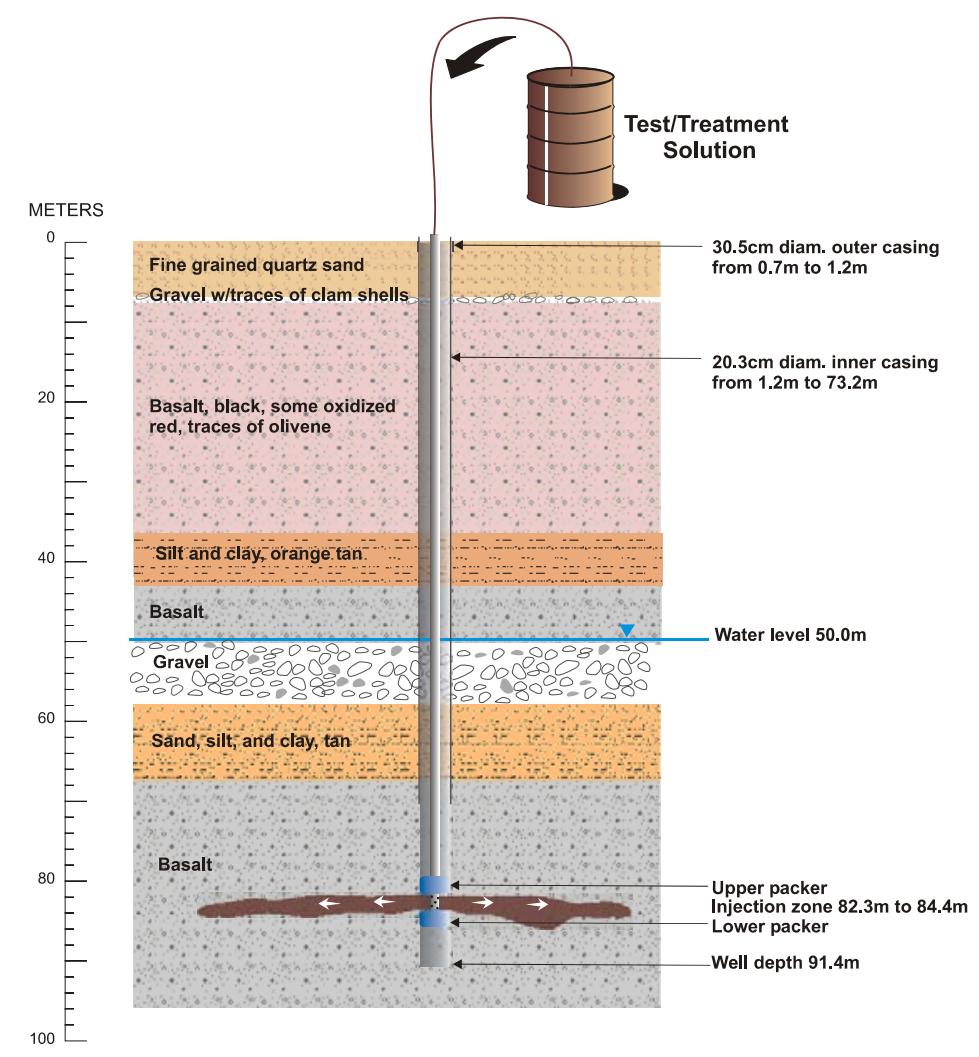

Figure 2. Schematic of lithology for UP-1 well, showing location of injection zone.

\section{Molasses and Urea Treatments}

Following a 13 day "pre-injection" period during which water samples were collected from UP-1 but no substrates were added, the first injection solution consisting of 650 L of UP-2 groundwater amended with $7.5 \mathrm{mg} \mathrm{L}^{-1}$ food-grade molasses (Grandma's Molasses, Riverton, NJ) was introduced into UP-1. Three days later another $1460 \mathrm{~L}$ of UP-2 groundwater with molasses (7.5 $\left.\mathrm{mg} \mathrm{L}^{-1}\right)$ was added; this was repeated 4 days later. The solutions were injected at the rate of $7.6 \mathrm{~L} \mathrm{~min}^{-1}$ and followed by $76 \mathrm{~L}$ (calculated volume of the borehole interval plus the volume of the injection line from the surface) of unamended UP-2 groundwater to flush the molasses 
solutions out of the borehole and injection line. Two days after the third molasses treatment, 580 L of UP-2 groundwater containing $50 \mathrm{mM}$ urea (Falls Fertilizer, Idaho Falls, ID) and $100 \mathrm{mg} \mathrm{L}^{-1}$ bromide (conservative tracer; added as $\mathrm{KBr}$ ) was added. The urea solution was followed by $76 \mathrm{~L}$ of UP-2 groundwater. The injection and sampling schedules are presented in Table 1. In total $26.8 \mathrm{~g}$ molasses, $1,742 \mathrm{~g}$ urea, and $86.3 \mathrm{~g} \mathrm{KBr}$ were injected over the course of the experiment.

Table 1. UP-1 sampling and molasses and urea injection schedule.

\begin{tabular}{|l|l|l|l|l|}
\hline Days & $\begin{array}{l}\text { Sample } \\
\text { Collection }\end{array}$ & $\begin{array}{l}\text { Sample } \\
\text { Designation }\end{array}$ & $\begin{array}{l}\text { Molasses } \\
\text { Injection }\end{array}$ & $\begin{array}{l}\text { Urea } \\
\text { Injection }\end{array}$ \\
\hline 0 & $\mathrm{x}$ & Pre-injection & & \\
6 & $\mathrm{x}$ & $\begin{array}{l}\text { Pre-injection } \\
\text { Pre-injection }\end{array}$ & & \\
8 & $\mathrm{x}$ & Pre-injection & & \\
10 & $\mathrm{x}$ & Pre-injection & $\mathrm{x}$ & \\
13 & $\mathrm{x}$ & Molasses 1 & $\mathrm{x}$ & \\
16 & $\mathrm{x}$ & Molasses 2 & $\mathrm{x}$ & \\
20 & $\mathrm{x}$ & Molasses 3 & & $\mathrm{x}$ \\
22 & $\mathrm{x}$ & Urea 1 & & \\
30 & $\mathrm{x}$ & Urea 2 & & \\
35 & $\mathrm{x}$ & & \\
\hline
\end{tabular}

Days refer to the elapsed time from the beginning of the experiment.

Note: Sample collection on the injection days occurred prior to injection of the test solutions.

\section{Sample Collection and Storage}

To ensure that groundwater samples were representative of the formation and not the borehole or injection line tubing, before every sampling event approximately 3 "borehole + tubing" volumes $(3 \times 76 \mathrm{~L}=228 \mathrm{~L})$ of groundwater were pumped and discarded. Triplicate groundwater samples for estimating in situ ureolysis rates, ureolytic cell most probable number (MPN) determinations, heterotrophic cell enumeration, and for urea and alkalinity measurement were collected in clean sterile containers and transported on ice to either the UI-IF or IRC laboratories within 2 hours of sample collection and processed immediately. For total cell number determinations, samples were amended with $2 \%$ formaldehyde for cell fixation directly after collection and stored at $4{ }^{\circ} \mathrm{C}$ until analysis. Samples collected for anions, cations, and dissolved organic carbon (DOC) were filtered in the field using a $0.45 \mu \mathrm{m}$ pore size in-line groundwater-sampling capsule (Gelman Laboratory, Ann Arbor, MI). The triplicate DOC samples were collected in organic-free glass containers and stored at $4{ }^{\circ} \mathrm{C}$ until analysis within a few days. Anion and cation samples were stored at $4{ }^{\circ} \mathrm{C}$ in clean polypropylene bottles until analysis. ICP-MS samples were acidified with concentrated nitric acid prior to storage. For the urease gene analyses, cells were concentrated by filtration on $0.2 \mu \mathrm{m}$ pore size Supor-200 membrane filters (142 mm; Pall Corporation, Ann Arbor, MI) in the field. Samples were collected in triplicate on each sampling date by simultaneously filtering $20 \mathrm{~L}$ of groundwater through three pre-sterilized filter units. Immediately following collection, filters were transferred to sterile centrifuge tubes and transported on dry ice to the laboratory for storage at $-80{ }^{\circ} \mathrm{C}$ until DNA extraction.

\section{Analytical Methods}

Dissolved oxygen (DO), $\mathrm{pH}$, oxidation reduction potential (ORP), temperature, and specific conductivity were determined at the wellhead using an in-line flow cell with a multiprobe (Hydrolab MiniSonde 4a, Loveland, CO). DOC was analyzed with a carbon analyzer 
(OI-700 TOC analyzer, O.I. Corporation, College Station, TX). Cations $\left(\mathrm{Ca}^{2+}, \mathrm{Mg}^{2+}, \mathrm{Na}^{+}, \mathrm{K}^{+}\right.$, $\mathrm{Sr}^{2+}$, and $\left.\mathrm{Ni}^{2+}\right)$ and aqueous silica $\left(\mathrm{SiO}_{2}\right)$ were analyzed using inductively coupled plasma-mass spectrometry (ICP-MS; Model 7500a Agilent, Palo Alto, CA). Anions $\left(\mathrm{Cl}^{-}, \mathrm{NO}_{3}{ }^{-}, \mathrm{NO}_{2}{ }^{-}, \mathrm{SO}_{4}{ }^{2-}\right.$, $\mathrm{PO}_{4}{ }^{3-}, \mathrm{F}^{-}$, and $\left.\mathrm{Br}^{-}\right)$and ammonium $\left(\mathrm{NH}_{4}{ }^{+}\right)$were analyzed using ion chromatography (IC; Dionex, Sunnyvale, CA). DOC, ICP-MS, and IC analyses were conducted using the standard methods recommended by the instrument manufacturers. Alkalinity was determined with an Orion Total Alkalinity Test Kit (Orion, Beverly, MA). Urea was measured using a spectrophotometric method based on the reaction of urea with p-dimethylaminobenzaldehyde (Knorst, 1997).

\section{Microbial Enumerations}

For the ureolytic cell MPN determinations, ten-fold dilution series $\left(10^{-1}\right.$ to $10^{-4}$ or $10^{-2}$ to $\left.10^{-6}\right)$ of the samples were prepared using filtered $(0.2 \mu \mathrm{m})$ groundwater as diluent. Five replicates were prepared at each dilution level for each of the triplicate samples. To each MPN tube $5 \mathrm{ml}$ of Urea R Broth (Difco, 1984) and $0.5 \mathrm{ml}$ of the appropriate groundwater dilution were added. The tubes were incubated at $21^{\circ} \mathrm{C}$ for 20 days; tubes which turned pink were counted as positive; salmon- and yellow-colored tubes were negative. The number of ureolytic cells per $\mathrm{ml}$ for each sampling date was estimated using a statistical program (Briones, 1999). For aerobic heterotroph cell counts, a ten-fold dilution series (100-10-4) in sterile phosphate buffered saline ( $\mathrm{pH}$ 7.4) was prepared for each of the triplicate samples. One hundred microliter aliquots of each dilution were spread onto R2A plates (Difco, Sparks, MD). The plates were incubated two weeks at $21^{\circ} \mathrm{C}$ before colonies were counted. Total cells in the groundwater were counted using DAPI (4', 6-diamidino-2-phenylindole, dihydrochloride) staining (Porter, 1980) and a Leica DMRB epifluorescence microscope (Leica, Inc., Wetzler, Germany) with appropriate filters (excitation $350 \mathrm{~nm}$, emission $470 \mathrm{~nm}$ ).

\section{Ureolysis Rate Estimation}

The in situ rates of ureolysis by cells in the recovered groundwater were estimated using a ${ }^{14} \mathrm{C}$ tracer technique (Wright, 1979). Nine milliliters of groundwater were added to a $25 \mathrm{ml}$ flask along with $59 \mathrm{nmol}$ [14C] urea $(7.7 \mathrm{mCi} / \mathrm{mmol}$; Sigma, St. Louis, MO) for a total volume of $10 \mathrm{ml}$. Triplicate flasks were incubated at $21^{\circ} \mathrm{C}$ for 0,24 or 48 hours. The reaction was stopped with the addition of $1 \mathrm{ml} 2 \mathrm{~N} \mathrm{H}_{2} \mathrm{SO}_{4}$, and evolved ${ }^{14} \mathrm{CO}_{2}$ was captured on filter paper saturated with $2 \mathrm{~N} \mathrm{NaOH}$, suspended above the solution. The ${ }^{14} \mathrm{CO}_{2}$ was measured by transferring the filter paper to scintillation cocktail (Scintisafe Plus 50\%, Fisher) and using an ultra low-level liquid scintillation counter (1220 Quantulus Wallac, Turku, Finland).

\section{Control Cultures for Real-Time Quantitative PCR of ureC gene}

Sporosarcina pasteurii (ATCC 11859) and Escherichia coli (ATCC 25922) were used as positive and negative controls for urease genes, respectively. S. pasteurii was grown in Brain Heart Infusion broth with $2 \%$ urea and E. coli was grown in Luria-Bertani broth. Both cultures were grown at $37^{\circ} \mathrm{C}$ overnight prior to DNA extraction.

\section{DNA Extraction}

DNA was extracted from the $S$. pasteurii and E. coli cultures using the UltraClean Microbial DNA Isolation Kit (MoBio, Solano Beach, CA). DNA was extracted from the filterconcentrated aquifer cells using a method based on that of Somerville et al. (Somerville, 1989), with minor modifications. The frozen filters were fragmented, thawed, and lysed with proteinase 
$\mathrm{K}\left(20 \mathrm{mg} \mathrm{ml}^{-1}\right.$ in $20 \mathrm{mM}$ EDTA, $50 \mathrm{mM}$ Tris- $\mathrm{HCl}, 400 \mathrm{mM} \mathrm{NaCl}, 0.75 \mathrm{M}$ sucrose, $\mathrm{pH}$ 9.0; $2 \mathrm{hr}$ ) and $1 \%$ sodium dodecyl sulfate $(1 \mathrm{hr})$ at $50^{\circ} \mathrm{C}$. Proteins were removed by sequential organic extractions (phenol:chloroform:isoamyl alcohol, 25:24:1, $\mathrm{pH} 8.0$; and chloroform:isoamyl alcohol, 24:1), incubating each for 30 minutes prior to centrifugation (12,000 x g; $5 \mathrm{~min})$. The DNA was precipitated with sodium acetate $(250 \mathrm{mM})$ and isopropanol $(0.5 \mathrm{X})$ overnight at -20 ${ }^{\circ} \mathrm{C}$. Following centrifugation $\left(4^{\circ} \mathrm{C}, 50,000 \mathrm{x} \mathrm{g}, 45 \mathrm{~min}\right)$ the DNA was washed with $70 \%$ ethanol, air dried, and stored in Tris buffer $\left(10 \mathrm{mM}\right.$, ph 8.0) at $-20^{\circ} \mathrm{C}$.

\section{Real-Time Quantitative PCR of ureC Gene}

The ure $\mathrm{C}$ gene codes for the catalytic subunit of urease in most bacteria; Helicobacter pylori is a well-known exception (DeReuse, 1997; Mobley, 1995). A real-time quantitative PCR (qPCR) assay was developed using the Lightcycler-FastStart DNA Master SYBR Green I kit (Roche Applied Science, Indianapolis, IN) with degenerate PCR primers targeting a 389-bp amplicon of ureC (Petzke, 2006). Primers L2F (5'-ATHGGYAARGCNGGNAAYCC-3') and L2R (5'-GTBSHNCCCCARTCYTCRTG-3') were designed in a previous study (Gresham, 2007). Each reaction contained 0.87X SYBR Master Mix, $3.5 \mathrm{mM} \mathrm{MgCl} 2$, and $170 \mathrm{nmol}$ of each primer. Prior to template ( $5 \mu \mathrm{L}$ genomic DNA) addition, the reaction mix was filtered through a Montage PCR Filter (Millipore, Billerica, MA) for $10 \mathrm{~min}$ at 1,000 x g to remove any possible DNA contamination. 0.3X SYBR Green I (Molecular Probes, Eugene, OR) was added to the filtered master mix to aid in real-time detection. The assay was performed on a Rotor-Gene 2000 (Corbett Research, Mortlake, Australia) with a 10 min hot-start polymerase activation at 95 ${ }^{\circ} \mathrm{C}, 40$ cycles of $95{ }^{\circ} \mathrm{C}$ for $15 \mathrm{~s}, 62{ }^{\circ} \mathrm{C}$ for $90 \mathrm{~s}, 72{ }^{\circ} \mathrm{C}$ for $15 \mathrm{~s}$, and $80{ }^{\circ} \mathrm{C}$ for $15 \mathrm{~s}$, a final denaturation at $95^{\circ} \mathrm{C}$ for $5 \mathrm{~s}$, and annealing at $50{ }^{\circ} \mathrm{C}$ for $2 \mathrm{~min}$. Melt curve analysis began at 50 ${ }^{\circ} \mathrm{C}$ for $5 \mathrm{~s}$, followed by $1{ }^{\circ} \mathrm{C}$ increases every min until $99^{\circ} \mathrm{C}$. Fluorescence was measured at 80 ${ }^{\circ} \mathrm{C}$. The threshold for fluorescence was set using the automated function on the Rotor-Gene software (version 5.0.61), and a standard curve relating the threshold cycle $\left(\mathrm{C}_{t}\right)$ to the ureC gene copy number was obtained by using $S$. pasteurii genomic DNA in a ten-fold dilution series from 268 copies to $2,680,000$ copies of $u r e C$ template per reaction. Template copy number was estimated by counting $S$. pasteurii cells using the Acridine Orange direct count method (Kepner, 1994), assuming one copy of the ureC gene per cell and complete recovery of DNA from the cells. All qPCR products were also run on a $2 \%$ agarose gel to verify that the amplified product was of the expected size.

\section{Analysis of solids collected after urea addition}

Because water samples collected after urea addition contained visible suspended solids, a $500 \mathrm{ml}$ sample collected on day 30 of the experiment was centrifuged $(5,500 \mathrm{x} \mathrm{g})$ and the solids were collected. The air-dried solids were analyzed by X-ray diffraction (XRD) using a Bruker D8 Advance X-ray Diffractometer (Bruker AXS, Congleton, Cheshire, UK) with a Cu K tube source (30 mA - $40 \mathrm{kV})$, single Gobels mirror, and a scintillation detector. Bruker "Eva" software was used to evaluate the samples. The solids were also examined by environmental scanning electron microscopy (SEM), using a Philips XL30 ESEM equipped with a LAB6 electron source (FEI Company, Hillsboro, OR, USA). The SEM system was equipped with an energy dispersive X-ray spectroscopy (EDS) system (Princeton Gamma-Tech, Princeton, NJ, USA) for determination of bulk elemental composition. 


\section{Results}

\section{UP-1 Groundwater Extraction}

Prior to urea introduction, at each sampling opportunity groundwater was extracted from UP-1 at $11.5 \mathrm{~L} \mathrm{~min}^{-1}$, and no changes in productivity were observed during pumping or between sampling dates. The urea solution was injected on day 22, and on day 23 attempts to extract groundwater failed because of pump malfunction, likely due to a local decrease in water inflow that caused overheating of the motor. The pump was replaced on day 28 , and the packed interval was lengthened by $0.7 \mathrm{~m}$ upward. Sampling occurred twice thereafter, on days 30 and 35 . However, the hydraulic productivity was much lower than before urea addition, and therefore the new pump was "pre-primed" by using groundwater from UP-2 to fill the pump outlet pipe in UP1 (approximately $38 \mathrm{~L}$ ) before turning on the pump. Then a volume equivalent to the added UP-2 groundwater was purged prior to sample collection. Only $151 \mathrm{~L}$ of groundwater per sampling event could be pumped from the well on days 30 and 35; previously no practical limits on pumping volumes from the well were observed.

The water retrieved from UP-1 after the urea addition was cloudy, with visible suspended solids (all previous samples had been free of visible solids). XRD analysis of collected solids indicated that they were predominantly calcite, with some quartz. SEM showed that at least some of the crystals were rhombohedral (typical of calcite) and generally on the order of $100 \mu \mathrm{m}$ in dimension (Figure 3). EDS analyses were consistent with calcium carbonate.

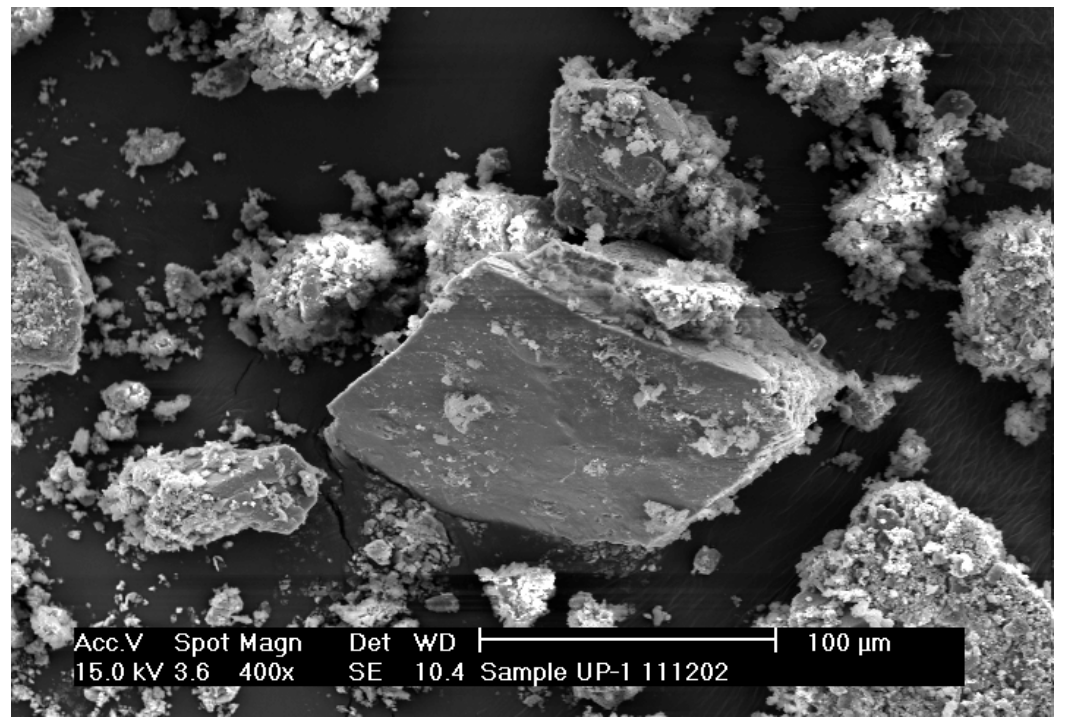

Figure 3. Scanning electron micrograph of calcite precipitate collected from UP-1 following urea addition.

\section{Water Chemistry}

Table 2 presents data for some of the measured water chemistry parameters throughout the experiment. Except for ammonium and bromide, the major cation and anion concentrations remained essentially constant and those data are not shown. The $\mathrm{pH}$ rose only very slightly during the course of the experiment, to an average of 7.12 after molasses and urea addition (average $\mathrm{pH}$ before molasses addition was $6.98 \pm 0.04$ ); no dramatic difference was observed following urea addition. After molasses addition, the DO remained at relatively high levels (typically 6-8 $\mathrm{mg} \mathrm{L}^{-1}$ ), suggesting that fermentation did not occur. The measured DOC in the molasses-amended water injected on days 13, 16 and 20 was $7.02 \pm 0.12 \mathrm{mg} \mathrm{L}^{-1}$ as C. DOC measurements on days 16, 20 and 22 indicated that this organic carbon was either mostly utilized or diluted/advected away within two to four days. 
Table 2. Water chemistry parameters measured in UP-1 during the field experiment.

\begin{tabular}{|c|c|c|c|c|c|c|c|c|c|c|}
\hline \multirow[b]{2}{*}{ Day $^{\mathrm{a}}$} & \multicolumn{5}{|c|}{ Pre-Injection (no treatment) } & \multicolumn{3}{|c|}{$\frac{\text { Post Molasses }}{\underline{\text { Treatment }}}$} & \multicolumn{2}{|c|}{$\frac{{ }^{*} \text { Post Urea }}{\text { Treatment* }}$} \\
\hline & 0 & 6 & 8 & 10 & 13 & 16 & 20 & 22 & 30 & 35 \\
\hline $\mathrm{pH}$ & 7.01 & 7.02 & 6.91 & 6.96 & 6.98 & 7.06 & 7.12 & 7.10 & 7.12 & 7.11 \\
\hline Alkalinity ${ }^{\mathrm{b}}$ & 219 & 209 & - & 219 & 217 & - & 220 & 222 & 223 & 217 \\
\hline D.O. ${ }^{\mathrm{c}}$ & 7.3 & 6.9 & 6.3 & 6.4 & 6.5 & 6.9 & 7.6 & 7.8 & 1.3 & 1.8 \\
\hline $\mathrm{DOC}^{\mathrm{d}}$ & 0.47 & 0.49 & 0.52 & 0.65 & - & 1.03 & 0.84 & 0.79 & 7.54 & 5.11 \\
\hline $\mathrm{Br}^{\mathrm{c}}$ & 0.26 & 0.21 & 0.19 & 0.16 & 0.19 & 0.11 & 0.11 & 0.09 & 1.15 & 0.85 \\
\hline $\mathrm{NH}_{4}{ }^{\mathrm{c}}$ & ND & ND & ND & ND & ND & ND & ND & ND & 1.03 & 0.73 \\
\hline Urea $^{e}$ & - & - & - & - & . & - & - & $<0.1$ & $0.8^{\mathrm{f}}$ & - \\
\hline
\end{tabular}

${ }^{\mathrm{a}}$ Days elapsed from start of field experiment; ${ }^{\mathrm{b}} \mathrm{mg} \mathrm{L}{ }^{-1} \mathrm{CaCO}_{3} ;{ }^{\mathrm{c}} \mathrm{mg} \mathrm{L}^{-1} ;{ }^{\mathrm{d}} \mathrm{mg} \mathrm{C} \mathrm{L}{ }^{-1} ;{ }^{\mathrm{e}} \mathrm{mM}$ Urea; ${ }^{\mathrm{f}}$ urea value is unreliable because of precipitation during analysis as described in text; DOC was used as an indicator of urea in solution. ND (Non Detect); - (Not Determined)

*The measured concentrations in the urea solution injected on day 22 (the water sample for that day was collected prior to urea introduction) were $54.7 \mathrm{mM}$ urea, $95.85 \mathrm{mg} \mathrm{L}^{-1} \mathrm{Br}$, and $3.11 \mathrm{mg} \mathrm{L}^{-1} \mathrm{NH}_{4}$ (due to impurity of urea).

The DOC content of the urea solution was much higher than that of the molasses solution, but because the urea carbon is fully oxidized, it was not expected to exert any direct oxygen demand. The measured urea concentration in the injectate was $54.7 \mathrm{mM}$, which corresponds to a DOC concentration of $656 \mathrm{mg} \mathrm{L}^{-1}$; the measured DOC was $630 \mathrm{mg} \mathrm{L}^{-1}$ as C (difference most likely to due to measurement error). Only a faint "signal" from this large DOC input was still observable 8 and 13 days after urea injection; a comparison of the respective ratios of bromide and DOC on day 35 to their day 0 values $\left(8.9 \mathrm{E}-3\right.$ for $\mathrm{Br}_{35} / \mathrm{Br}_{0}$ and $8.1 \mathrm{E}-3$ for $\mathrm{DOC}_{35} / \mathrm{DOC}_{0}$ ) suggests that most of the DOC loss was likely due to dilution/advection. Interestingly, DO also decreased following urea addition. A possible reason is increased metabolic activity of the microbial community due to the acquisition of nitrogen from urea hydrolysis.

Our attempts to spectrophotometrically analyze for urea in the post urea groundwater samples were hampered by the formation of precipitates during the analytical process. Therefore, although urea was likely present in the post urea-injection water samples we could not quantify the amount. Urea hydrolysis in the subsurface was however indicated by the higher ammonium ratio (concentration extracted/concentration injected; the initial concentration of ammonium in the urea solution was $3.11 \mathrm{mg} \mathrm{L}^{-1}$ due to impurity of the urea) compared to the analogous ratio for the conservative tracer bromide; 8 days after urea injection, the ammonium ratio was $28 \mathrm{X}$ higher than the corresponding bromide ratio. Nitrite, the first product of ammonia oxidation, was never detected, although PCR techniques reflected the presence and changes in the distribution of ammonium oxidizing bacteria over the course of the experiment (Freeman et al., 2006, Appendix F). In addition, the nitrate concentrations increased slightly, from a preinjection concentration of $1.5 \pm 0.1$ to $2.1 \pm 0.2 \mathrm{mg} \mathrm{L}^{-1}$ (as $\mathrm{N}$ ). The latter value is still well below the U. S. EPA maximum contaminant level for nitrate $\left(10 \mathrm{mg} \mathrm{L}^{-1}\right.$ as $\left.\mathrm{N}\right)$. 
Enumeration of Subsurface Microbes

After the first molasses

treatment, the number of planktonic cells in the extracted groundwater increased by approximately an order of magnitude, and continued increasing with each molasses addition. In the samples collected after urea addition, total cell numbers were lower but still well above the pre-injection levels (Figure 4). Heterotrophic cell counts increased almost 2 orders of magnitude, and also remained greater than the preinjection levels in the two post urea samples. A similar increasing trend (i.e., a 10X increase after the first molasses treatment, to over two orders of magnitude increase by the third molasses treatment) was observed with the numbers of ureC gene copies estimated using the qPCR method. However, the ureolytic cell MPN assays showed a very different response (Figure 5). Both methods for estimating ureolytic cell numbers gave similar estimates for the preinjection samples (few 10's of cells per ml; separate axes for the two parameters are shown in order to more easily discern the difference in trends), but after nutrient addition the results diverged. After the first molasses treatment, no significant change in MPN estimates was observed. After the second molasses treatment one of the triplicate sets of MPN tubes indicated a 3 order of magnitude increase in ureolytic cells, but the other two sets showed only a one order of magnitude increase. Samples collected subsequently, including after urea addition, showed MPN results more similar to the pre-injection values. The qPCR method showed a decrease in urease

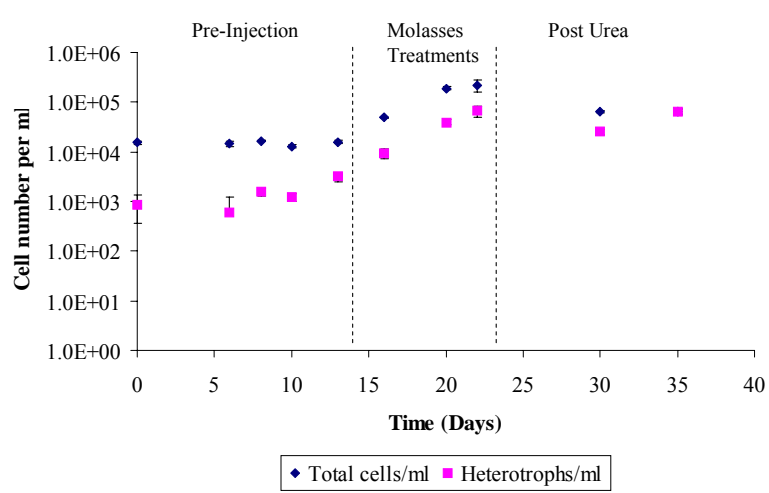

Figure 4. Changes in numbers of total cells (diamonds) and heterotrophic cells (squares) over the course of the field experiment. Error bars represent one standard deviation (triplicate samples); where not visible the bars are smaller than the data symbol or the standard deviation is greater than the mean (heterotroph count on day 6). Background samples were collected on days $0,6,8,10$ and 13 , and samples exposed to molasses were collected on days 16,20 , and 22. Samples on days 30 and 35 were collected 8 and 13 days after urea injection.

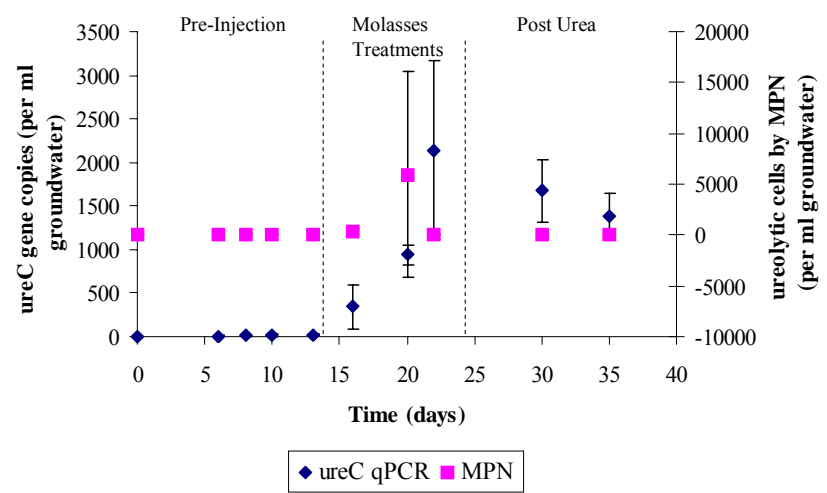

Figure 5. Changes in numbers of ure $\mathrm{C}$ gene copies (diamonds) and ureolytic cells by MPN (squares) over the course of the field experiment. Error bars represent one standard deviation (triplicate samples); where not visible the bars are smaller than the data symbol. Background samples were collected on days 0 to 13 , and samples exposed to molasses were collected on days 16, 20, and 22. Samples on days 30 and 35 were collected 8 and 13 days after urea injection. 
gene targets in the two samples collected after urea addition relative to before urea, but the values were still well above the pre-injection levels.

\section{Ureolytic Activity in Extracted Groundwater}

The average estimated ureolysis rate in the groundwater samples under pre-injection conditions was less than $0.1 \mathrm{nmol}$ urea hydrolyzed $\mathrm{L}^{-1} \mathrm{hr}^{-1}$. Following the first molasses treatment the estimated rates increased 50-fold, and after the second and third treatment the rates increased to 300 times pre-injection levels (Figure 6). After urea addition on day 22 of the experiment, a sample was not obtained until day 30 . By this time, the estimated rate had dropped to approximately $0.9 \mathrm{nmol} \mathrm{L}^{-1} \mathrm{hr}^{-1}$, and five days later the rate was lower, but still above the preinjection level, at $0.4 \mathrm{nmol} \mathrm{L}^{-1} \mathrm{hr}^{-1}$.

\section{Discussion}

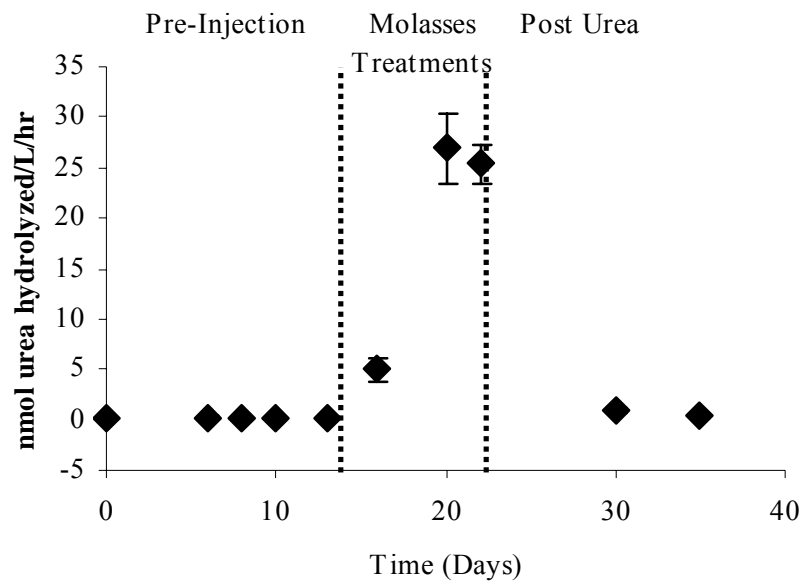

Figure 6. Estimated in situ ureolysis rates in UP-1 over the course of the experiment. Error bars represent one standard deviation (triplicate samples); where not visible the bars are smaller than the data symbol. Pre-injection samples were collected on days 0 to 13, and samples exposed to molasses were collected on days 16, 20, and 22. Samples on days 30 and 35 were collected 8 and 13 days after urea injection.

\section{Effects of nutrient addition}

Nutrient addition increased the proportion of urease-positive bacteria (measured by qPCR), relative to total microbial cells, in the UP-1 groundwater. Table 3 shows that the percentage of cells containing ureC genes increased with each molasses addition, and was highest after urea addition. Table 3 also shows the rate of urea hydrolysis on a per cell basis, both per total cell and per ureolytic cell (as estimated by qPCR). The ureolysis rate per cell increased with the molasses treatment, with the highest value observed after the second molasses addition. After urea addition the cell-normalized ureolysis rates were closer to the pre-injection rates. This suggests that the urease-positive cells that were apparently stimulated by the treatment did not necessarily exhibit high specific urease activity. This is more clearly indicated by the rate measurements on a per ureolytic cell basis. The lowest values for this ratio were seen after urea addition, when the proportion of ureolytic cells in the community was highest. Conversely, the highest ratios were measured in the first two background samples, when the relative abundances of ureolytic cells were lowest. These particular values may however simply reflect the very low numbers of ure $\mathrm{C}$ gene copies measured in those samples, $<10$ per $\mathrm{ml}$; considerable uncertainty can be associated with the quantitation of very low gene copy numbers (Chandler, 1998). 
Table 3. Different measures of specific (per cell) ureolytic activity for samples acquired from UP-1 over the course of the molasses and urea stimulation experiment.

\begin{tabular}{|c|c|c|c|}
\hline $\begin{array}{l}\text { Day and } \\
\text { Experimental Phase }\end{array}$ & $\begin{array}{l}\text { \% Urease positive } \\
\text { cells }^{\mathrm{a}}\end{array}$ & $\begin{array}{l}\text { Urea hydrolyzed per } \\
\left.\text { cell (fmol hr-1 } \text { cell }^{-1}\right)\end{array}$ & $\begin{array}{l}\text { Urea hydrolyzed per } \\
\text { ureolytic cell (fmol } \\
\left.\text { hr }^{-1} \text { cell }^{-1}\right)^{b}\end{array}$ \\
\hline $0-$ Pre-injection & $0.01 \%$ & 0.005 & 35.2 \\
\hline 6 - Pre-injection & $0.04 \%$ & 0.015 & 35.2 \\
\hline 8 - Pre-injection & $0.08 \%$ & 0.003 & 4.2 \\
\hline 10 - Pre-injection & $0.14 \%$ & 0.005 & 3.3 \\
\hline 13 - Pre-injection & $0.15 \%$ & 0.004 & 2.7 \\
\hline 16 - Post molasses & $0.43 \%$ & 0.061 & 14.2 \\
\hline 20 - Post molasses & $0.49 \%$ & 0.141 & 28.7 \\
\hline 22 - Post molasses & $0.98 \%$ & 0.116 & 11.9 \\
\hline 30 - Post urea & $2.59 \%$ & 0.014 & 0.5 \\
\hline 35 - Post urea & $2.09 \%$ & 0.006 & 0.3 \\
\hline
\end{tabular}

${ }^{\mathrm{a}}$ Calculated as ratio of qPCR result (ureolytic cells per ml) to total cell count (cells per $\mathrm{ml}$ ).

${ }^{\mathrm{b}}$ Ureolytic cells determined by qPCR (assuming one copy ureC gene per cell).

In addition to the qPCR method, we tested an MPN technique for estimating ureolytic cell numbers. However, the latter appeared to be ill-suited for our study. Although other measures indicated that microbial ureolysis activity was stimulated in our experiment, the MPN technique did not appear to be sensitive to the changes. It is possible that ureolytic cell numbers were not in fact affected by the nutrient additions, but it seems unlikely given the observed changes in ureolysis rates, and the increases in total cell numbers. The MPN method is a cultivation-based technique, and it is possible that the cultivation conditions used were unsuitable for many of the organisms that were actually ureolytic in the environment. In addition, a large number of replicates is required to ensure statistical significance (Koch, 1994); perhaps our triplicate sets of 4 (dilutions) x 5 replicates were simply not sufficient. Due to these difficulties, in future work we expect to rely solely on the ureC gene qPCR method for estimating numbers of ureolytic bacteria. The qPCR results were consistent with the ureolysis rate measurements, suggesting that ure $\mathrm{C}$ gene numbers may serve as a useful indicator for trends in ureolytic rates. Current research is underway in our laboratory to investigate this further, as well as evaluate the relationship between ureC gene transcript (mRNA) numbers and rates.

Urea injection resulted in a rapid $(<24 \mathrm{hr})$ and dramatic decrease in water productivity from the experimental zone. Prior to the start of the experiment, extensive pumping experience at the field site had indicated that the production of water from the system was limited by the pump, rather than the formation, and exceeded $20 \mathrm{~L} \mathrm{~min}^{-1}$. A new, smaller (3/4 hp) pump was installed on day 28 , which involved resetting the packer system. Following additional review of the downhole video logs the interval between the packers was increased by $0.7 \mathrm{~m}$ upward, allowing a previously "untreated" (and thus presumably higher hydraulic conductivity) zone to contribute water to the experiment. Testing immediately following reseating of the packers suggested that the new interval could produce water at a rate in excess of our requirements for sampling. Because the water column in the wellbore was mixed by the removal and replacement of the packer system, the well was allowed to "rest" for 2 days prior to sampling. On day 30 sampling was resumed. However, by this time sufficient reduction in hydraulic conductivity had occurred such that only $151 \mathrm{~L}$ of water could be extracted. The last sample was withdrawn on Day 35. The decrease in well productivity was likely the result of both an increase in attached 
biomass stimulated by the provision of nitrogen and mineral precipitation. As noted previously, calcite precipitates were observed in water collected after urea addition.

The goal of the UP-1 field experiment was to determine the effect of the nutrient amendment regime on the overall kinetics of urea hydrolysis in the ESRPA at this location. Although the pump replacement and the limited number of post-urea injection samples constrain our ability to accurately quantify in situ urea hydrolysis rates, simple calculations using the available field data can be used to provide reasonable estimates of urea hydrolysis rates, as described in the following sections.

\section{Urea Hydrolysis Kinetics in a Sorbing Medium}

Under conditions of first order kinetics, the rates of urea hydrolysis and ammonium production are given by:

$$
\begin{gathered}
R_{\text {urea }}=\frac{d[\text { urea }]}{d t}=-k[\text { urea }] \\
R_{N_{4}^{+}}=\frac{d\left[\mathrm{NH}_{4}^{+}\right]^{\text {total }}}{d t}=2 k[\text { urea }]
\end{gathered}
$$

where $R_{i}$ is the rate of change in concentration for the subscripted species, $t$ is time and $k$ is the rate constant. The concentrations, $[\mathrm{urea}]$ and $\left[\mathrm{NH}_{4}^{+}\right]^{\text {total }}$ are expressed on a per liter of water basis. The urea concentration at time $\mathrm{t}$ is given by integrating equation (2) from time 0 to time $t$ :

$$
[\text { urea }]=[\text { urea }]_{0} e^{-k t}
$$

where $[u r e a]_{0}$ is the urea concentration at time 0 . The ammonium concentration at time $t$ is given by substitution of equation (4) into equation (3) and integrating from time 0 to time $t$ :

$$
\left[N H_{4}^{+}\right]^{\text {total }}=2[\text { urea }]_{0}\left(1-e^{-k t}\right)+\left[N H_{4}^{+}\right]_{0}^{\text {total }}
$$

where $\left[\mathrm{NH}_{4}{ }^{+}\right]_{0}{ }^{\text {total }}$ is the total concentration of ammonium at time 0 . In the subsurface, ammonium can exchange with cations on the aquifer matrix and only a fraction of the total ammonium remains in solution:

$$
\begin{aligned}
& f_{a q}=\frac{\left\lfloor N H_{4}^{+}\right\rfloor}{\left[N H_{4}^{+}\right]^{\text {total }}}=\frac{\left\lfloor N H_{4}^{+}\right\rfloor}{\left[N H_{4}^{+}\right]+\left[N H_{4}^{+}\right]^{r o c k}} \\
& {\left[N H_{4}^{+}\right]^{\text {total }}=\frac{\left[N H_{4}^{+}\right]}{f_{a q}}}
\end{aligned}
$$

where $f_{a q}$ is the fraction of ammonium that remains in solution. In subsurface media subject to reversible linear sorption, the fraction of a sorbing constituent that remains in solution is related to the retardation factor $R_{f}$ by (Palmer, 1997): 


$$
R_{f}=\frac{1}{f_{a q}}
$$

Substituting equations (6) and (7) into equation (5) under the condition of no initial ammonium yields:

$$
\left[\mathrm{NH}_{4}^{+}\right]=\frac{2[u r e a]_{0}}{R_{f}}\left(1-e^{-k t}\right)
$$

Equations (4) and (8) allow tracking of the decrease of urea and the accumulation of aqueous ammonium in the aquifer. Equations (4) and (8) require that $[u r e a]_{0}, k$, and $R_{f}$ be defined. The value of $[u r e a]_{0}$ can be defined by the design of the experiment. The other two parameters can be estimated from time series groundwater concentrations. First, the value of $k$ is estimated by linear regression from time series urea concentrations and the natural log transformed equation (4), next the value of $R_{f}$ is estimated by linear regression from time series ammonium concentration and equation (8). Conversely, if the $R_{f}$ value for ammonium can be determined independently of the urea injection, the rate constant $k$ can be estimated from equation (8) and the measured ammonium concentrations.

\section{UP-1 Conceptual Model}

Conceptually our experimental results can be considered to represent conditions in two zones of the aquifer. The first is the biologically active zone (BAZ) subjected to molasses and urea injections. We can operationally define the BAZ as the zone where bromide (co-injected with urea) is present. Mineral precipitation and a possible biomass increase resulted in a permeability reduction, trapping the injected urea solution in the BAZ. The second zone consists of the portion of the aquifer that became part of the experiment due to the elevation of the upper packer by $0.7 \mathrm{~m}$ after the pump replacement. This zone originally had permeability and water chemistry characteristics similar to the pre-urea injection conditions (Note: This zone, henceforth called the "background" zone, could have been impacted by the molasses injections, which were not associated with any detectable changes in subsurface permeability prior to urea injection). Water samples collected on days 30 and 35 are mixtures of water from these two zones; due to the differences in hydraulic conductivity, we can assume that the bulk of the water is derived from the background zone and only a small portion of the water is derived from the BAZ. Equation (9) shows the representative binary mixing equation:

$$
\begin{gathered}
{\left[\boldsymbol{M}_{S}\right]=\lambda \cdot\left[\boldsymbol{M}_{\mathbf{B A Z}}\right]+(1-\lambda) \cdot\left[\boldsymbol{M}_{\mathbf{B k g d}}\right\rfloor} \\
\lambda=\frac{\left[\boldsymbol{M}_{\boldsymbol{S}}\right]-\left[\boldsymbol{M}_{\mathbf{B k g d}}\right]}{\left[\boldsymbol{M}_{\mathbf{B A Z}}\right]-\left[\boldsymbol{M}_{\mathbf{B k g d}}\right]}
\end{gathered}
$$

where $\lambda$ is fraction of water derived from the BAZ and $\left[M_{S}\right],\left[M_{B A Z}\right]$, and $\left[M_{B k g d}\right]$ are the molar concentrations of constituent $\mathrm{M}$ (e.g., $\mathrm{Br}^{-}, \mathrm{NH}_{4}{ }^{+}$, urea, and DOC) in the collected sample, the BAZ, and the background zone, respectively. $\lambda$ is independent of the chemical constituent considered. 
In the experiment, bromide was injected as a non-reactive tracer along with the reactive substrate urea. By simultaneously considering bromide and a reactive constituent, Equation (9) can be solved to eliminate $\lambda$

$$
\left.\frac{M_{S}^{*}}{B r_{S}^{*}}=\frac{\left[M_{S}\right]-\left\lfloor M_{B k g d}\right\rfloor}{\left[B r_{S}\right]-\left[B r_{B k g d}\right]}=\frac{\left[M_{B A Z}\right]-\left\lfloor M_{B k g d}\right\rfloor}{\left[B r_{B A Z}\right]-\left[B r_{B k g d}\right.}\right]
$$

where $\left[\mathrm{MS}_{S}^{*}\right] /\left[\mathrm{Br}_{S}^{*}\right]$ is the molar ratio of the reactive constituent to the conserved tracer, corrected for their respective background (pre-urea) concentrations. A similar formulation is presented by Haggerty et al. (1998) for analysis of reaction kinetics in single well push-pull tests. Table 4 shows the values of $\left[\mathrm{MS}_{S}{ }^{*}\right] /\left[\mathrm{Br}_{S}{ }^{*}\right]$ calculated using equation $(10)$ and the results presented in Table 2 . The values of $\left[M_{S}{ }^{*}\right] /\left[\mathrm{Br}_{S}{ }^{*}\right]$ in Table 4 explicitly account for dilution and mixing that occurred during sampling and allow both the assessment of changes that occurred in the BAZ and the application of equations (4) and (8) to estimate the in situ rate of urea hydrolysis and the associated $R_{f}$ for ammonium.

Table 4 - The composition of the background (prior to urea injection) groundwater, the urea injectate, and post-urea injection water samples collected on days 30 and 35 . The lower portion of the table contains calculated background corrected molar ratios for the urea injectate (day 22) and for water samples collected on days 30 and 35 as described in the text, along with the estimated values for $k, R_{f}$, and $\mathrm{DOC}_{B k g d}$. Assumptions supporting Scenarios 1 through 3 are described in the text and Supporting Information.

\begin{tabular}{|c|c|c|c|c|}
\hline & Bkgd & Injectate & Day 30 & Day 35 \\
\hline $\mathrm{Br}^{-}(\mu \mathrm{M})$ & 1.1 & 1120 & 14.4 & 10.7 \\
\hline $\mathrm{DOC}(\mu \mathrm{M})$ & & \multirow{4}{*}{54700} & \multirow{4}{*}{628} & \multirow{4}{*}{426} \\
\hline Scenario 1 & 74.1 & & & \\
\hline Scenario 2 & 222 & & & \\
\hline Scenario 2 & 145 & & & \\
\hline \multirow[t]{3}{*}{$\mathrm{NH}_{4}^{+}(\mu \mathrm{M})$} & 0.00 & 172 & 57.1 & 40.4 \\
\hline & \multicolumn{3}{|c|}{ Day } & \\
\hline & 22 & 30 & 35 & \\
\hline \multicolumn{5}{|l|}{$\left[\mathrm{DOC}_{\mathrm{S}}{ }^{*}\right] /\left[\mathrm{Br}_{\mathrm{S}}{ }^{*}\right]$} \\
\hline Scenario 1 & 45.6 & 41.7 & 36.7 & \\
\hline Scenario 2 & 45.6 & 30.6 & 21.3 & \\
\hline Scenario 3 & 45.6 & 36.4 & 29.3 & \\
\hline \multirow[t]{2}{*}[\mathrm{NH}_{4,\mathrm{S}}{}^{*}]{$/\left[\mathrm{Br}_{\mathrm{S}}{ }^{*}\right]$} & 0.1 & 4.3 & 4.2 & \\
\hline & $k\left(d^{-1}\right)$ & $\boldsymbol{R}_{f}$ & \multicolumn{2}{|c|}{$\mathrm{DOC}_{B k g d}\left(\mathrm{mg} \mathrm{L}^{-1}\right)$} \\
\hline Scenario 1 & 0.016 & 3.5 & \multicolumn{2}{|l|}{0.89} \\
\hline Scenario 2 & 0.057 & 10.8 & \multicolumn{2}{|l|}{2.7} \\
\hline Scenario 3 & 0.033 & 6.6 & \multicolumn{2}{|l|}{1.7} \\
\hline
\end{tabular}

\section{Field-Scale Urea Hydrolysis Kinetics}

Because we were unable to reliably determine the urea concentration in samples collected after urea injection, we cannot directly estimate the in situ hydrolysis rate. However, the rate can be bounded by considering alternative interpretation scenarios. In all of these scenarios it is 
assumed that DOC can be used as a surrogate for urea, with corrections for the DOC in the background samples. The background DOC derives from natural DOC in the ESRPA, and also molasses, and is assumed to be constant during each of the scenarios. This assumption is in fact questionable, as it is more likely that the abundance of background DOC changed during the course of the experiment as a result of a general stimulation of the subsurface microbial community. The latter condition was suggested by the observed decrease in dissolved oxygen following urea injection (see Table 2). Given the concentration of $\mathrm{Br}^{-}$in the samples collected after urea injection, less than $1 \%$ of the water sample was derived from the BAZ. If the background water contained $7.0 \mathrm{mg} \mathrm{L}^{-1} \mathrm{DO}$ (the pre-injection average), then the measured DO concentration in the sample should have been $>6.9 \mathrm{mg} \mathrm{L}^{-1}$, rather than the 1.3 to $1.8 \mathrm{mg} \mathrm{L}^{-1}$ observed on days 30 and 35. The change in DO of the background water was likely due to increased biological activity, which would typically be accompanied by changes in DOC. Nevertheless, the hydrolysis rates predicted using this assumption appears to be reasonable as compared to previous field experimental data, as explained below.

In the first scenario, we assumed that the "background" DOC concentration $\left(0.89 \mathrm{mg} \mathrm{L}^{-1}\right.$; $74.1 \mu \mathrm{M}$ ) is the average of the measured DOC in the samples collected following each of the molasses injections (i.e., samples collected on days 16, 20, 22), and that the additional DOC measured in the day 30 and 35 samples is attributable to urea. Using the calculated $\left[D O C_{S}{ }^{*}\right] /\left[\mathrm{Br}_{S}{ }^{*}\right]$ ratios as a surrogate for urea concentration and equation (4), the first order rate constant for urea hydrolysis, $k$, was estimated by non-linear least squares regression. The derived rate constant, the values of $\left[\mathrm{NH}_{4},{ }^{*}\right] /\left[\mathrm{Br}_{S}{ }^{*}\right]$ from Table 4 , and equation (8) were then used to estimate $R_{f}$ by nonlinear least squares regression. The results of this scenario are shown in Figure 6a. Only $1.6 \%$ of the injected urea is predicted (using equation 4 ) to have hydrolyzed during the first day of the experiment; however significant loss of permeability in the BAZ was observed after 1 day.

In the second scenario, values of $\left[\mathrm{NH}_{4, S^{*}}\right] /\left[\mathrm{Br}_{S} *\right]$ from Table 4 and equation (8) were used with a $R_{f}$ value for $\mathrm{K}^{+}$(a monovalent cation with similar size to $\mathrm{NH}_{4}^{+}$) to estimate the urea hydrolysis rate constant $k$ by nonlinear least squares regression. The $R_{f}$ value for $\mathrm{K}^{+}$was estimated from a previous column experiment in our laboratory where urea and potassium bromide were added to simulated ESRPA groundwater passed through a column filled with crushed basalt from the ESRPA, and breakthrough curves for urea, $\mathrm{Br}^{-}$and $\mathrm{K}^{+}$were determined (data not published). The breakthrough curves for urea and bromide were indistinguishable from each other, suggesting negligible sorption of urea by basalt. However, the $\mathrm{K}^{+}$breakthrough curve showed retardation, allowing us to estimate the retardation factor for $\mathrm{K}^{+}$in the column $\left(R_{f}=2.3\right)$; for the calculations in Scenario 2 the column $R_{f}$ was corrected for the difference in porosity between the column experiment $(\theta=0.53)$ and the porosity estimated for SRPA consolidated basalt $(\theta=0.127$; Smith, 2001). The estimated $\mathrm{k}$ was used with equation (4) to calculate the $\left[D O C_{S}^{*}\right] /\left[\mathrm{Br}_{S}{ }^{*}\right]$ at each of the two post-urea samplings. From those values, and the known measurements of bromide and DOC in the sample, an average background value of DOC was estimated. The results of this scenario are shown in Figure 6b. Scenario two suggests that the background DOC concentration was $2.7 \mathrm{mg} \mathrm{L}^{-1}(222 \mu \mathrm{M})$, rather than the $0.9 \mathrm{mg} \mathrm{L}^{-1}(74.1$ $\mu \mathrm{M})$ assumed in the first scenario. This would be consistent with an increase in bioactivity, as supported by the depletion of DO after urea addition. In addition, the observed decrease in well productivity between the resetting of the packer and the first sampling 2 days later is consistent with increased bioactivity in the newly exposed experimental region. However, it should be noted that the background concentration for DOC is a strong function 
(d[DOC $]_{\mathrm{bkgd}} / \mathrm{d} R_{f}=0.25 \mathrm{mg} \mathrm{L}^{-1}$ ) of the value of $R_{f}$ selected and hence depends heavily on the validity of our assumption that the $R_{f}$ for $\mathrm{K}^{+}$based on laboratory column experiments can be used to represent the field-scale behavior of $\mathrm{NH}_{4}^{+}$.

A third scenario was considered in which the background DOC concentration, $k$, and $R_{f}$ were simultaneously optimized by nonlinear least squares fit, using the data from the day 30 and 35 samples, and the injectate composition. The results of this scenario are presented in Figure 6c. In this optimization the resulting background DOC was $1.7 \mathrm{mg} \mathrm{L}^{-1}(145 \mu \mathrm{M})$, midway between the values for the first $\left(0.9 \mathrm{mg} \mathrm{L}^{-1}\right)$ and second scenario $\left(2.7 \mathrm{mg} \mathrm{L}^{-1}\right)$. The corresponding values of $R_{f}$ and $k$ (6.6 and 0.033 day $^{-1}$, respectively) are also mid way between their corresponding values for scenarios 1 (3.5 and 0.016 day $^{-1}$, respectively) and 2 (10.8 and 0.057 day $^{-1}$, respectively). Because scenario 3 does not require any a priori assumptions regarding either the background DOC concentration or the value of $R_{f}$, the values for the ammonium $R_{f}$ and for $k$ estimated from scenario 3 seem the most robust.

If the $k$ values derived from the three scenarios are used to calculate rates that can be compared to the rates measured using the ${ }^{14} \mathrm{C}$ method (assuming $59 \mathrm{nmol}$ urea in $10 \mathrm{ml}$ for 48 $\mathrm{hrs}$ ), the rates range from approximately 4 to $13 \mathrm{nmol}$ urea hydrolyzed $\mathrm{L}^{-1} \mathrm{hr}^{-1}$; the rates measured by the ${ }^{14} \mathrm{C}$ method for the samples collected after urea addition were 0.9 and $0.4 \mathrm{nmol} \mathrm{L}^{-1} \mathrm{hr}^{-1}$. Several factors likely account for the disparity in the values. One is that the lab rate does not account for the borehole dilution that occurs during sampling; as noted previously, after urea injection probably less than $1 \%$ of the water sample collected was derived from the BAZ. Moreover, only the activity of planktonic cells is measured in the extracted water samples; many previous researchers have suggested that attached and planktonic cells differ in activity, and attached communities may in fact be more important in aquifers, e.g. (Alfreider, 1997; Hazen, 1991; Lehman, 2001; Lehman, 2002; Thomas, 1987). Our own research conducted on paired core and water samples collected from the ${ }^{90} \mathrm{Sr}$ contaminated Hanford $100-\mathrm{N}$ area site suggest that over $99 \%$ of the ureolytic activity both in terms of ureC gene copies and measured ${ }^{14} \mathrm{C}$ urea hydrolysis is associated with the attached rather than planktonic organisms (Fujita et al., in prep). The aforementioned factors would tend to reduce the lab estimate relative to the field estimate. However, another factor, temperature, would have the opposite effect. The aquifer temperature measured in the borehole was consistently $12^{\circ} \mathrm{C}$, while the laboratory temperature was typically 10 degrees higher; such a change would be expected to increase the ureolysis rate by more than a factor of 10 (Ferris et al., 2004, Appendix B). Given these differences in what was actually measured, the fact that the field and lab values agree within a factor of 5 to 10 is encouraging and suggests that we are able to get a relatively robust estimate of actual field rates from the laboratory measurements. The laboratory measurements are useful because they can gauge temporal changes occurring in the system, and as such can be used to monitor a remediation activity over time. In contrast, the estimated field rate integrates all of the temporal changes in order to come up with a single value.

The estimated first order field urea hydrolysis rate constant of 0.033 day $^{-1}$ from the third scenario is a factor of 3 higher than that derived from an earlier experiment at another ESRPA location that involved the co-injection of urea and molasses, the latter at a much higher concentration $\left(10 \mathrm{~g} \mathrm{~L}^{-1}\right)$ than used here (Colwell et al., 2005, Appendix A; Smith et al., 2005). These results suggest that our strategy of multiple pre-treatments with low concentrations of molasses prior to urea introduction is more effective than the simultaneous injection of both the carbon source and the urea. The $R_{f}$ value of 6.6 estimated from scenario 3 predicts that 
approximately $85 \%$ of the produced ammonium is sorbed by the aquifer matrix, consistent with the displacement of metals by cation exchange.

Based on the $\mathrm{k}$ value of $0.033 \mathrm{day}^{-1}$, the estimated half-life for urea in the field experiment was about 20 days, indicating that by 3 months after injection approximately $95 \%$ of the urea would have hydrolyzed. This hydrolysis rate when coupled with ambient flow conditions at UP-1 would allow a treatment zone extending approximately 30 meters down gradient of the injection well.

The relative contributions of biomass and mineral precipitation to a reduction in the subsurface permeability could not be discerned in this experiment. Neither could we determine the spatial distribution of the zone of reduced permeability - was it primarily just in the vicinity of the borehole wall, or did it extend out into the formation, and if so, how far? Answering such questions, and understanding how to monitor, predict and control the distribution of precipitation and changes in permeability are critical challenges which must be addressed in order to develop this remedial approach into a field deployable technology. New monitoring techniques, advanced modeling approaches, and field testing of different manipulation strategies/amendment injection regimes will be needed.

We have shown that the introduction of a dilute molasses solution followed by urea successfully stimulated the ESRPA groundwater ureolytic community without causing the well to become anaerobic. Urea added to the aquifer was hydrolyzed, and enhanced calcite precipitation was observed. The results of the experiment indicate that we can manipulate subsurface ureolysis rates and accelerate calcite precipitation, and bode well for the potential of this approach to be adapted for use in groundwater systems contaminated with divalent cations that may be co-precipitated with calcite.

\section{Personnel Supported}

\section{Undergraduate students}

S. Freeman

M.R. Taylor

\section{Graduate students}

J.L. Taylor, M.S.

T. (Tyler) Gresham, Ph.D.

L. Petzke, M.S.

C. Zachary

M. Bernal

C.E. Corriveau

S. Byington
Postdoctoral fellow

Dr. M.S. Beig

\section{Publications}

Peer-reviewed journals

Colwell, F.S., R.W. Smith, F.G. Ferris, A-L. Reysenbach, Y.Fujita, T.L. Tyler, J.L. Taylor, A. Banta, M.E. Delwiche, T.L. McLing, and M.E. Watwood. 2005. Microbially mediated subsurface calcite precipitation for removal of hazardous divalent cations: Microbial activity, molecular biology, and modeling. A.C.S. symposium series. 904:117-137.

Ferris, FG, V. Phoenix, Y. Fujita, and R.W. Smith. 2004. Kinetics of calcite precipitation 
induced by ureolytic bacteria at 10 to 20 degrees $\mathrm{C}$ in artificial groundwater. Geochim. Cosmochim. Acta. 68:1701-1710.

Freeman, S., D.W. Reed, and Y. Fujita. 2006. Testing the specificity of primers to environmental ammonia monooxygenase (AMOA) genes in groundwater treated with urea to promote calcite precipitation. U.S. Department of Energy Journal of Undergraduate Research. 6:114-118.

Fujita, Y., G.D. Redden, J.A. Ingram, M.M. Cortez, and R.W. Smith. 2004. Strontium incorporation into calcite generated by bacterial ureolysis. Geochim. Cosmochim. Acta. 68:3261-3270.

Gresham, T.L.T., P.P. Sheridan, M.E. Watwood, Y. Fujita, and F.S. Colwell. 2007. Design and validation of ureC-based primers for groundwater detection of urea-hydrolyzing bacteria. Geomicrobiology Journal. 24:353-364.

Collaborators Peer-reviewed journals (Project Number: DE-FG07-99ER15025)

Mitchell, A. C. and F.G. Ferris, 2006. The Influence of Bacillus pasteurii on the Nucleation and Growth of Calcium Carbonate, Geomicrobiology Journal, 23:213 - 226

Mitchell, A. C. and F.G. Ferris. 2005. The co-precipitation of Sr into calcite precipitates induced by bacterial ureolysis in artificial groundwater: Temperature and kinetic dependence. Geochim. Cosmochim. Acta. 69:4199-4210.

\section{Submitted for publication}

Fujita, Y., J.L. Taylor, T.L.T. Gresham, M.E. Delwiche, F.S. Colwell, T.M. McLing, L. Petzke, R.W. Smith. Stimulation of microbial urea hydrolysis in groundwater to enhance calcite precipitation. Environmental Science and Technology.

\section{Graduate student theses}

Taylor, J. L. 2003. Stimulation of microbial urea hydrolysis in groundwater for remediation of metal contaminants. In M.S. Thesis. Environmental Science and Waste Management, Idaho State University, Pocatello, ID.

Petzke, L.M. 2006. Quantification of bacterial urease genes in the environment. In M.S. Thesis. Biology, Idaho State University; Pocatello, ID.

Tyler (Gresham), T.L. 2004. Detection and characterization of urease genes in groundwater bacterial communities. In Ph.D Dissertation. Biology, Idaho State University, Pocatello, ID.

Corriveau, C.E. (M.S. in progress, University of Idaho, Moscow, ID) 


\section{Presentations}

2002

Cortez, M., J.C. Ingram, Y. Fujita, and R. Avci. Secondary Ion Mass Spectrometry of biotic and abiotic co-precipitation of strontium and calcium carbonate. Poster. American Chemical Society National Meeting. Boston, MA, August 2002.

Fujita, Y., J.C. Ingram, M.M. Cortez, G.D. Redden, and R. W. Smith. Strontium incorporation into calcite generated by bacterial ureolysis. Eos Trans. AGU, 83(47), American Geophysical Union Fall Meet. Suppl., Abstract B11B-0728, 2002.

Phoenix V.R. and F.G. Ferris. Kinetics of calcite precipitation induced by ureolytic bacteria at 10 to $20{ }^{\circ} \mathrm{C}$ in artificial groundwater. Eos Trans. AGU, 83(47), American Geophysical Union Fall Meet. Suppl., Abstract B11B-0727, 2002

Taylor, J.L., Y. Fujita, M.E. Delwiche, F.S. Colwell, and M.E. Watwood. Evaluation of various nutrient additions for enhancement of urea hydrolysis by Snake River Plain Aquifer microorganisms. Poster. Intermountain Conference on the Environment. Pocatello, ID, 2002.

Taylor, J.L., M.E. Delwiche, Y. Fujita, F.S. Colwell, and M.E. Watwood. Evaluation of aquifer urease activities using a single well "Push-Pull" test. Poster. American Society for Microbiology (ASM) 102nd General Meeting. Salt Lake City, UT, May 2002.

Taylor, J. L., M.E. Delwiche, Y. Fujita, T.L. Tyler, F.S. Colwell, and M. E. Watwood. Field test of a method to co-precipitate strontium with calcite in a fractured basalt aquifer. Oral Presentation. Spectrum 2002 Conference. Reno, NV, August 2002.

Tyler, T.L., P.P. Sheridan, M.E. Watwood, and F.S. Colwell. Primers for amplifying genes encoding ureases in subsurface microbial communities. Poster. American Society for Microbiology (ASM) 102nd General Meeting. Salt Lake City, UT. May 2002.

2003

Fujita, Y., J.L. Taylor, T.L. Tyler, A.B. Banta, A-L. Reysenbach, M.E. Delwiche, T.L. McLing, F.S. Colwell, and R. W. Smith. Field experiment to stimulate microbial urease activity in groundwater for in situ calcite precipitation. Eos Trans. AGU, 84(46), Fall Meet. Suppl., Abstract B42E-07, 2003.

Fujita Y., J.L. Taylor, T.L. Tyler, M.E. Delwiche, T.L. McLing, F.S. Colwell, and R.W. Smith. Stimulation of groundwater urease activity for in situ calcite precipitation: A field trial. International Symposium on Environmental Biogeochemistry. Aomori, Japan, September 2003.

Smith R.W., Y. Fujita, and F.G. Ferris. Co-precipitation of trace metals in groundwater and 
vadose zone calcite: in situ contaminant and stabilization of strontium-90 and other divalent metals and radionuclides at arid western DOE sites. FY2003 EMSP Principal Investigator Workshop, Richland, WA May 6-7, 2003. http://www.pnl.gov/emsp/fy2003/presentations/smith_bob_87016.pdf

Smith, R. W. and Y. Fujita. Biogeochemistry of strontium-90 remediation by microbially mediated calcite precipitation: potential application at Hanford, Washington. Poster. Geological Society of America meeting. Seattle, 2003.

Smith R.W., D.M. Cosgrove, J.L. Taylor, Y. Fujita, F.S. Colwell, and T.L. McLing. Remediation of metal contaminants by microbially mediated calcite precipitation. Inland Northwest Research Alliance (INRA) Subsurface Science Symposium. Salt Lake City, UT, 2003.

Tyler T.L., P.P. Sheridan, M.E. Watwood, and F. S. Colwell. Diversity of culturable, ureolytic bacteria isolated from a deep aquifer in a semi-arid high desert region. Poster. American Society for Microbiology national meeting. Washington, DC, May 2003.

2004

Fujita, Y., M.R. Taylor, J.L. Taylor, T.L. Tyler, L.M. Petzke, M.E. Delwiche, D.W. Reed, and R. W. Smith. Ureolytic activity at the Hanford 100-N Area: Potential for microbially facilitated calcite precipitation? Oral presentation. Inland Northwest Research Alliance Subsurface Science Symposium. Spokane, WA, September 2004.

Petzke, L. M., T.L. Tyler, M.S. Shields, D.W. Reed, and Y. Fujita. Quantitation of bacterial urease genes in groundwater by Real-Time PCR. Poster. American Society for Microbiology general meeting. New Orleans, LA, May 2004.

Tyler, T. L., P.P. Sheridan, M.E. Watwood, Y. Fujita, and F. S. Colwell. PCR-DGGE Analysis of Natural Ureolytic Bacterial Communities During an in situ Remediation Field Test. Poster. American Society for Microbiology general meeting. New Orleans, LA, May 2004.

2005

Fujita, Y. Microbially accelerated calcite precipitation for in situ immobilization of ${ }^{90} \mathrm{Sr}$. State Regulators Consensus Workshop. NABIR BASIC Program. Phoenix, AZ, 2005.

Fujita, Y., L. M. Petzke, et al. Characterizing microbial ureolytic activity in groundwater for the potential to facilitate calcite precipitation for remediation of strontium-90. Goldschmidt Conference. Moscow, ID. 2005.

Fujita, Y., J. L. Taylor, et al. Characterizing microbial communities in a deep oligotrophic aquifer: an in situ incubation experiment. Joint International Symposia for Subsurface Microbiology and Environmental Biogeochemistry. Jackson, WY, 2005. 
Fujita, Y., J. L. Taylor, et al. Characterizing ureolytic activity by attached microorganisms in a deep aquifer. Inland Northwest Research Alliance Environmental and Subsurface Science Symposium. Big Sky, MT, 2005.

Petzke, L. M., D. W. Reed, et al. Detection and enumeration of bacterial urease mRNA by quantitative reverse-transcription PCR. Joint International Symposia for Subsurface Microbiology and Environmental Biogeochemistry. Jackson, WY, 2005.

Reed, D. W., L. M. Petzke, et al. Quantification of ammonia oxidizing bacteria in groundwater treated with urea to promote calcite precipitation. Joint International Symposia for Subsurface Microbiology and Environmental Biogeochemistry. Jackson, WY, 2005.

Smith, R.W., J L. Taylor, and Y. Fujita. Simultaneous field estimates of urea hydrolysis rates and ammonium retardation factors in a fractured rock aquifer. AGU. San Francisco, CA, 2005.

Taylor, J.T., R.W. Smith, M. E. Delwiche, Y. Fujita, F. S. Colwell, T. McLing, and T. Tyler. A method comparison for ureolysis rates in the Snake River Plain Aquifer. First International Conference on Environmental Science and Technology. New Orleans, LA, 2005.

2006

Corriveau, C.E. M.S. Beig, and R.W. Smith. Kinetics of calcite precipitation/strontium co-precipitation. Inland Northwest Research Alliance Environmental Sub-surface Symposium. Moscow, ID, September 2006.

Fujita, Y. Microbially facilitated calcite precipitation for immobilization of strontium-90 in the subsurface. Invited presentation at Subsurface Biosphere Initiative Workshop/IGERT Retreat. Newport, OR, June 2006.

2007

Byington, S., D. Reed, and Y. Fujita. Detection and quantification of ammonia oxidizing archaea (AOA) in groundwater treated for novel remediation of strontium. Poster. Intermountain Conference on the Environment. Idaho State University, September 2007.

Corriveau, C.E., M.S. Beig, and R.W. Smith. Sequestering strontium-90 by calcite precipitation: predicting Sr-90 uptake in the Eastern Snake River Plain Aquifer. Geological Society of America Rocky Mountain Section Meeting. St. George, UT, May 2007

Reed, D., L. Petzke, S. Freeman, and Y. Fujita. Quantification of ammonia oxidizing bacteria (AOB) from groundwater and basalt following urea treatment to promote calcite precipitation for strontium immobilization. Poster at Idaho Academy of Sciences Meeting. Idaho Falls, ID, April 2007. 
Reed, D., L. Petzke, S. Freeman, S. Byington, and Y. Fujita. Quantification of ammonia oxidizing bacteria and archaea from groundwater and basalt following urea treatment to promote calcite precipitation for strontium immobilization. Oral presentation at Inland Northwest Research Alliance Subsurface and Environmental Science Symposium. Logan, UT, July 2007.

\section{References}

Alfreider, A., M. Krossbacher, and R. Psenner. 1997. Groundwater samples do not reflect bacterial densities and activity in subsurface system. Water Research. 31: 832-840.

Chandler, D. P. J. 1998. Redefining relativity: quantitative PCR at low template concentrations for industrial and environmental microbiology. Ind. Microbiol. Biotechnol. 21:128-140.

Colwell, F. S. and R.M. Lehman. 1997. Microbial communities from hydrologically distinct zones of a basalt aquifer. Microb. Ecol. 33:240-251.

Colwell, F.S., R.W. Smith, F.G. Ferris, A-L. Reysenbach, Y.Fujita, T.L. Tyler, J.L. Taylor, A. Banta, M.E. Delwiche, T.L. McLing, and M.E. Watwood. 2005. Microbially mediated subsurface calcite precipitation for removal of hazardous divalent cations: Microbial activity, molecular biology, and modeling. A.C.S. symposium series. 904:117-137.

Briones, A. M. and W.J. Reichardt. 1999. Estimating microbial population counts by most probable number using Microsoft Excel. Journal of Microbiological Methods. 35:157161.

De Reuse, H., A. Labigne, and D. Mengin-Lecreulx. 1997. The Helicobacter pylori gene ureC codes for a phosphoglucosamine mutase. J. Bacteriol. 179:3488-3493.

DEQ. 2006. Idaho Department of Environmental Quality.

Difco Manual. Dehydrated Culture Media and Reagents for Microbiology, Tenth ed. Difco Laboratories. Detroit, MI, 1984.

DOE. 2006. Operable Unit 3-14 Tank Farm Soil and Groundwater Remedial Investigation/Baseline Risk Assessment. U. S. Department of Energy.

Ferris, FG, V. Phoenix, Y. Fujita, and R.W. Smith. 2004. Kinetics of calcite precipitation induced by ureolytic bacteria at 10 to 20 degrees $\mathrm{C}$ in artificial groundwater. Geochim. Cosmochim. Acta. 68:1701-1710.

Freeman, S., D.W. Reed, and Y. Fujita. 2006. Testing the specificity of primers to environmental ammonia monooxygenase (AMOA) genes in groundwater treated with urea to promote calcite precipitation. U.S. Department of Energy Journal of Undergraduate Research. 


\section{6:114-118.}

Fujita, Y., F.G. Ferris, D.L. Lawson, F.S. Colwell, and R.W. Smith. 2000. Calcium carbonate precipitation by ureolytic subsurface bacteria. Geomicrobiol. J. 2000, 17, 305-318.

Fujita, Y., G.D. Redden, J.A. Ingram, M.M. Cortez, and R.W. Smith. 2004. Strontium incorporation into calcite generated by bacterial ureolysis. Geochim. Cosmochim. Acta. 68:3261-3270.

Gego, E.L., G.S. Johnson, M.R. Hankin, A.H. Wylie, and J.A. Welhan. 2002. Modeling ground water flow and transport in the Snake River Plain Aquifer: A stochastic approach. In Geology, Hydrogeology and environmental remediation, Idaho National Engineering and Environmental Laboratory, Eastern Snake River Plain, Idaho. P.K. Link and L.L. Mink eds. Geological Society of America Special Paper. 353:249-262.

Gresham, T.L.T., P.P. Sheridan, M.E. Watwood, Y. Fujita, and F.S. Colwell. 2007. Design and validation of ureC-based primers for groundwater detection of urea-hydrolyzing bacteria. Geomicrobiology Journal. 24:353-364.

Haggerty, R., M.H. Schroth, and J.D. Istok. 1998. Simplified method of "Push-Pull" test data analysis for determining In Situ reaction rate coefficients. Ground Water. 36: 314-324.

Hazen, T. C., L. Jimenez, G.L. Devictoria, and C.B. Fliermans. 1991. Comparison of bacteria density and activity in groundwater and adjacent sediments. Microb. Ecol. 22:293-304.

Hill, C. M. 2004. Evaluation of strontium-90 treatment technologies for the 100-NR-2 groundwater operable unit. U. S. DOE.

Kepner, R.L. Jr., and J.R. Pratt. 1994. Use of fluorochromes for direct enumeration of total bacteria in environmental samples: past and present. Microbiol. Rev. 58:603-615.

Knobel, L. L., R.C. Bartholomay, L.D. Cecil, B.J. Tucker, and S.J. Wegner. 1992. Chemical constituents in the dissolved and suspended fractions of ground water from selected sites, Idaho National Engineering Laboratory and vicinity, Idaho. U. S. Geological Survey.1992.

Knorst, M.T., R. Neubert, and W. Wohlrab. 1997. Analytical methods of measuring urea in pharmaceutical formulations. Journal of Pharmaceutical Methods and Biomedical Analysis. 15:1627-1632.

Koch, A. L. 1994. Growth measurement. In Methods for general and molecular bacteriology. Gerhardt, P., R.G.E. Murray, W.A. Wood, and N.R. Krieg. Eds., American Society for Microbiology Press: Washington, DC. 249-277.

Lehman RM, F.F. Roberto, D. Earley, D.F. Bruhn, S.F. Brink, S.P. O'Connell, M.E. Delwiche, and F.S. Colwell. 2001. Attached and unattached microbial communities in closely- 
paired groundwater and core samples from an acidic, crystalline rock aquifer. Appl. Environ. Microbiol. 67(5): 2095-2106.

Lehman RM and S.P. O'Connell. 2002. Comparison of extracellular enzyme activities and community composition of attached and free-living bacteria in porous media columns. Appl. Environ. Microbiol. 68(4): 1569-1575.

Lehman, R. M., S.P. O'Connell, A. Banta, J.K. Fredrickson, A-L Reysenbach, T.K. Kieft, T. L. and F.S. Colwell. 2004. Microbiological comparison of core and groundwater samples collected from a fractured basalt aquifer with dialysis chambers incubated In Situ. Geomicrobiol. J. 21:169 - 182.

Mitchell, A. C. and F.G. Ferris. 2005. The coprecipitation of Sr into calcite precipitates induced by bacterial ureolysis in artificial groundwater: Temperature and kinetic dependence. Geochim. Cosmochim. Acta. 69:4199-4210.

Mobley, H. L. and R.P. Hausinger. 1989. Microbial ureases: significance, regulation, and molecular characterization. Microbiol Rev. 53:85-108.

Mobley, H.T.L., M.D. Island, and R.P. Hausinger. 1995. Molecular biology of microbial ureases. Microbiol. Rev. 59:451-480.

Moore,R.C., C. Sanchez, K. Holt, P.C. Zhang, H. Xu, and G.R. Choppin. 2004. Formation of hydroxyapatite in soils using calcium citrate and sodium phosphate for control of strontium migration. Radiochimica Acta. 92 (9-11): 719-723.

NRC Research Needs in Subsurface Science - U.S. Department of Energy's Environmental Management Science Program; National Research Council, National Academy Press: Washington, D.C., 2000.

O'Connell, S. P., R.M. Lehman, O. Snoeyenbos-West, V.D. Winston, D.E. Cummings, M.E. Watwood, and F.S.Colwell. 2003. Detection of archaeal 16S rDNA sequences from an oxic basalt aquifer. FEMS Microbiol. Ecol. 44:165-173.

Palmer, C. D.; Fish, W. Chemically enhanced removal of metals from the subsurface. In Subsurface Restoration; Ward, C. H., Cherry, J. A., Scalf, M. R., Eds.; Ann Arbor Press, Inc.: Chelsea, Michigan, 1997; pp 217-230.

Petzke, L.M. 2006. Quantification of bacterial urease genes in the environment. In M.S. Thesis. Biology, Idaho State University; Pocatello, ID.

Porter, K.G. and Y.S. Feig. 1980. The use of DAPI for identifying and counting aquatic microflora. Limnol. Oceanogr. 25:943-948.

Riley, R. G. and J,M. Zachara. 1992. Chemical Contaminants on DOE Lands and Selection of Contaminant Mixtures for Subsurface Science Research. U. S. Department of Energy, 
Office of Energy Research.

Smith, R.W. 2001. In American Geophysical Union Fall Meeting; EOS Trans. AGU: San Francisco. Vol. Fall Meet. Suppl. 82(47).

Smith, R. W, J.T. Taylor, Y. Fujita. 2005. Simultaneous field estimates of urea hydrolysis rates and ammonium retardation factors in fractured rock aquifer. EOS Transactions, 86, Fall Meet. Supplement, Abstract B33C-1049.

Somerville, C.C., I.T. Knight, W.L. Straube, and R.R. Colwell. 1989. Simple, rapid method for direct isolation of nucleic acids from aquatic environments. Appl. Environ. Microbiol. 55:548-554.

Taylor, J. L. 2003. Stimulation of microbial urea hydrolysis in groundwater for remediation of metal contaminants. In M.S. Thesis. Environmental Science and Waste Management; Idaho State University: Pocatello, ID.

Thomas, J. M., M. D. Lee, and C. H. Ward. 1987. Use of ground water in assessment of biodegradation potential in the subsurface. Environ. Toxicol. Chem. 6:607-614.

Warren, L. A. P.A. Maurice, N. Parmar, and F.G. Ferris. 2001. Microbially Mediated Calcium Carbonate Precipitation: Implications for Interpreting Calcite Precipitation and for SolidPhase Capture of Inorganic Contaminants. Geomicrobiol. J. 18:93-115.

Wood, W. W. and W.H. Low. 1986. Aqueous geochemistry and diagenesis in the Eastern Snake River Plain Aquifer system. Geol. Soc. Amer. Bull. 97:1456-1466.

Wright, R. T., and B.K. Burnison. 1979. Heterotrophic activity measured with radiolabelled organic substrates, p. 140-155. In W.J. Costerson, and R.R. Colwell (eds), Native aquatic bacteria: enumeration, activity, and ecology. American Society for Testing and Materials. 


\section{Appendix A:}

Microbially mediated subsurface calcite precipitation for removal of hazardous divalent cations: Microbial activity, molecular biology, and modeling.

By F.S. Colwell, R.W. Smith, F.G. Ferris, A-L. Reysenbach, Y.Fujita, T.L. Tyler, J.L. Taylor, A. Banta, M.E. Delwiche, T.L. McLing, and M.E. Watwood.

In A.C.S. symposium series. 904:117-137 (2005). 


\title{
Chapter 6
}

\section{Microbially Mediated Subsurface Calcite Precipitation for Removal of Hazardous Divalent Cations: Microbial Activity, Molecular Biology, and Modeling}

\author{
Frederick S. Colwell ${ }^{1}$, Robert W. Smith ${ }^{2}$, F. Grant Ferris ${ }^{3}$, \\ Anna-Louise Reysenbach ${ }^{4}$, Yoshiko Fujita ${ }^{1}$, Tina L. Tyler ${ }^{1,5}$, \\ Joanna L. Taylor ${ }^{1,5}$, A. Banta ${ }^{4}$, Mark E. Delwiche ${ }^{1}$, \\ Travis L. McLing ${ }^{1}$, and Mary E. Watwood ${ }^{5}$ \\ ${ }^{1}$ Idaho National Engineering and Environmental Laboratory, \\ Idaho Falls, ID 83415-2203 \\ ${ }^{2}$ University of Idaho, Idaho Falls, ID 83402 \\ ${ }^{3}$ University of Toronto, Toronto, Ontario M5S 3B1, Canada \\ ${ }^{4}$ Portland State University, Portland, OR 97207-0751 \\ ${ }^{5}$ Idaho State University, Pocatello, ID 83209
}

\begin{abstract}
Current approaches for remediating hazardous divalent cations in aquifers are costly, can generate large volumes of waste, and focus on the small amounts of contaminants in the water rather than the larger reservoir of contamination sorbed to the aquifer matrix. An alternative to waste removal and repackaging is to encourage in situ biogeochemical processes to permanently bind the contaminants in the mineral matrix of an aquifer. Our research involves one such approach in which we accelerate calcite precipitation (an on-going geochemical process in arid western aquifers) and the assisted co-precipitation of cationic contaminants like strontium-90 using biologically driven urea hydrolysis to increase aquifer $\mathrm{pH}$ and alkalinity. This paper
\end{abstract}


describes progress related to stimulating and measuring indigenous urease activities in aquifer microbes and how these activities can be modeled for application in an aquifer of concern to the U.S. Department of Energy. Experiments using ${ }^{14} \mathrm{C}$-labeled urea indicated that microbial communities from the Snake River Plain aquifer (SRPA) of eastern Idaho hydrolyzed urea at rates higher than those measured for a model urea hydrolyzing bacterium (Bacillus pasteurii) under similar conditions, if they were provided a source of organic carbon along with the urea. By using a phylogenetic approach for analyzing urease gene sequences we developed polymerase chain reaction primer pairs that detected the ureC gene in urease positive microbial isolates. In a field test where molasses and urea were added to the SRPA, the ca. 400 base pair ureC fragment was amplified from DNA extracted from aquifer cells. Amplification and sequencing of bacterial $16 \mathrm{~S}$ rDNA gene fragments from the aquifer before and after the molasses and urea additions indicated measurable changes in the communities as a result of the treatment. Rate constants derived from urease activity experiments were used to simulate the calcite precipitation process in the SRPA. The model predicts that field application would result in three distinct geochemical reaction phases: a condition where urea hydrolysis rates exceed calcite precipitation rates, a condition where calcite precipitation rates exceed urea hydrolysis rates, and finally a condition where the two rates are equal. The model also indicates that most of the metals that are precipitated as carbonates will come from the aquifer matrix, not the groundwater. These two modeling observations suggest that when the rates of calcite precipitation and urea hydrolysis are equal, the entire process can be described by a pseudo-first order kinetic model. In this model the calcite precipitation rate is controlled by the urea hydrolysis rate and is independent of the concentration of calcium in the groundwater. The use of these techniques for determining the response of microbial communities to urea additions, as well as the predictive capabilities of the model, will allow better control and evaluation of pending field experiments to test calcite precipitation as an approach for contaminant removal from aquifers. 


\section{Introduction}

Radionuclide and metal contaminants are present in the vadose zone and groundwater at many of the U.S. Department of Energy (DOE) sites (1). Although the protection of groundwater is of primary concern, any remedial treatment must account for the large amount of contaminant that is sorbed to the aquifer matrix and serves as a continuing source of groundwater contamination. In situ containment and stabilization of these contaminants in vadose zones or groundwater is a cost-effective treatment strategy (2). However, implementing in situ containment and stabilization requires definition of the mechanism that controls contaminant sequestration. One mechanism for sequestration of metals and radionuclides is co-precipitation in authigenic calcite and calcite overgrowths (3). Calcite, a common mineral in many aquifers and vadose zones in the arid western United States, can incorporate divalent metals such as strontium, cadmium, lead, and cobalt into its crystal structures by the formation of solid solutions. For strontium-90, a radioisotope of concern to DOE, the calcite precipitation approach can be particularly effective. Because strontium-90 has a radioactive half-life of about 30 years, a period of only 300 years is required to eliminate $>99.9 \%$ of its radiologic hazard. Thus, removal of this radioisotope from the groundwater by securing it in a calcite mineral phase followed by control of the groundwater geochemistry to prevent calcite dissolution can be an effective way to treat this contaminant.

Our approach, shown schematically in Figure 1, for encouraging calcite precipitation and co-precipitation of divalent cations relies upon addition of a carbon source (e.g., molasses) to an aquifer followed by the addition of urea. While calcite precipitation occurs naturally in these aquifers urea hydrolysis by the in situ microbial community causes an acceleration of calcite precipitation (and trace metal co-precipitation) by increasing groundwater $\mathrm{pH}$ and alkalinity. This process has been demonstrated under laboratory conditions with Bacillus pasteurii, a microorganism that constitutively hydrolyzes urea (4). Urea hydrolysis and calcite precipitation have also been demonstrated, albeit more slowly, using microbial isolates acquired from the Snake River Plain Aquifer (SRPA), a groundwater system of significance to the DOE in the context of contamination (3). Because many western aquifers are saturated with respect to calcite and the precipitation processes are irreversible for these aquifers, the co-precipitated metals and radionuclides will be effectively removed from groundwater. The newly formed calcite should be stable as the aquifer returns to pre-treatment conditions and as long as the $\mathrm{pH}$ in the aquifer remains at normal values $(>7)$. The urea hydrolysis approach has the added advantage that the ammonium ions produced by the reaction can potentially exchange with radionuclides sorbed to subsurface minerals, thereby enhancing the susceptibility 


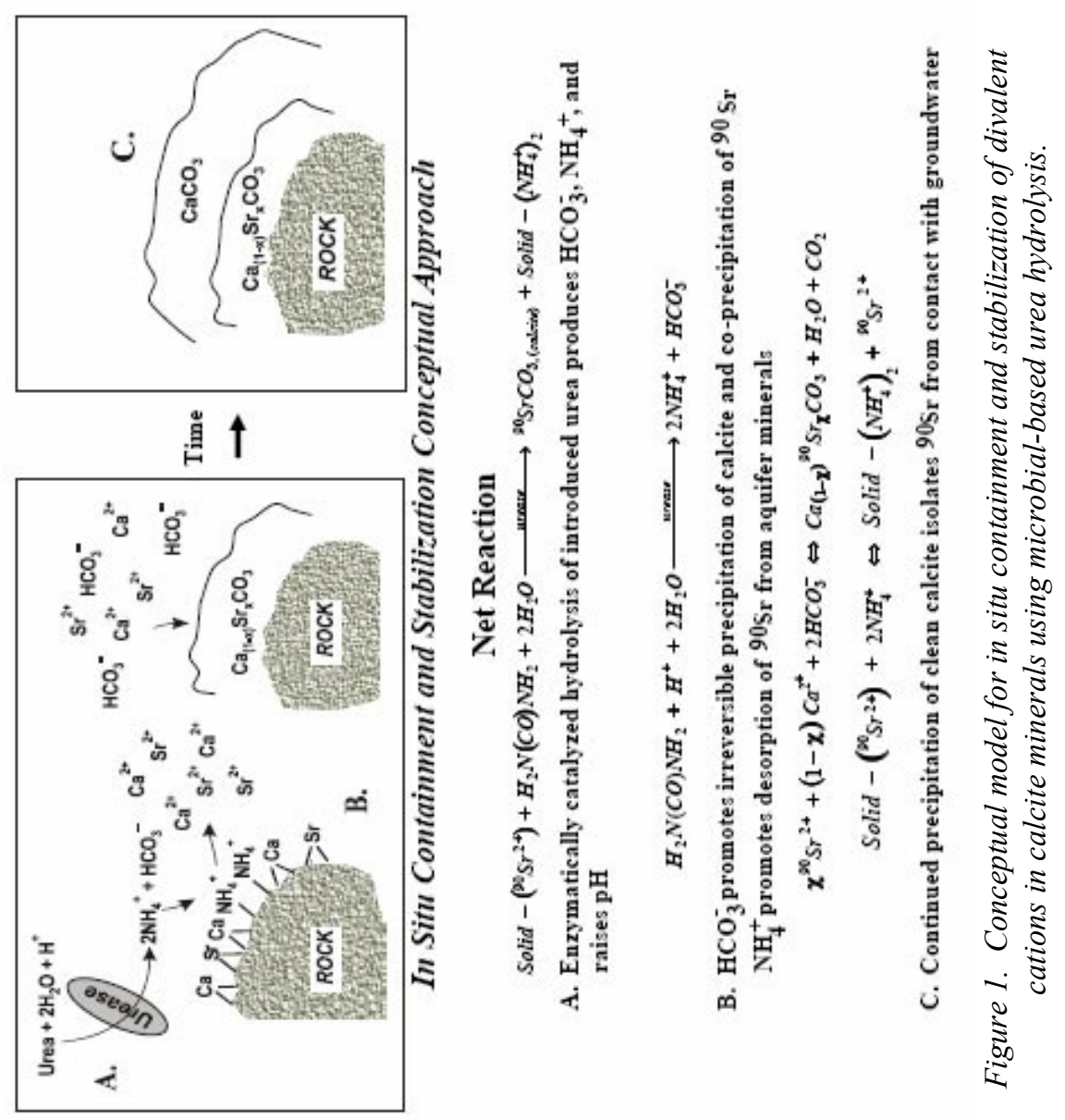


of the radionuclides for re-capture in a more stable solid phase (co-precipitation rather than adsorption).

Although the coupling of calcite precipitation and trace metal partitioning is theoretically a useful means to control divalent contaminants, a fundamental understanding of how urea hydrolysis-based calcite precipitation occurs in aquifers and vadose zone environments is lacking. In this study we had two specific research objectives. First we attempted to determine the urease activities of groundwater consortia from the aquifer and model these activities to estimate how the process may work in situ, prior to the actual field test. To achieve the first objective we relied upon groundwater samples collected from research well (UP-1) with characteristics representative of the uncontaminated SRPA. Second, we wanted to determine the usefulness of urease-specific polymerase chain reaction (PCR) primers and $16 \mathrm{~S}$ rDNA-specific primers for detecting molecular level changes in the aquifer communities. To achieve the second objective we characterized groundwater communities before and after a field experiment that was designed to maximize community shift and conducted in a well (Second Owsley) with characteristics representative of a contaminant plume (e.g., low dissolved $\mathrm{O}_{2}$ ) in the SRPA.

\section{Materials and Methods}

\section{Field Sites and Aquifer Experiment}

The SRPA is a large, freshwater, semi-confined aquifer that exists beneath the semi-arid high desert in southeastern Idaho. The Quaternary volcanicsedimentary stratigraphic sequence in the subsurface consists of multiple monogenetic tholeiitic basalt flows interbedded with thin sedimentary zones (5). Typically, the basalts are porphyritic containing phenocrysts or olivine and plagioclase in a fine-grained matrix that consists of interlocking plagioclase, augite, Fe-Ti bearing oxide minerals and glass (see 6 ).

Preliminary field experiments were conducted at Second Owsley $\left(43^{\circ} 48^{\prime}\right.$ 19.495" N latitude, $112^{\circ} 38^{\prime} 09.014^{\prime \prime}$ W longitude), a $94.4 \mathrm{~m}$ deep well that accesses the SRPA where the depth to groundwater is $68 \mathrm{~m}$ below land surface (mbls). Prior to the investigation the water in Second Owsley had a pH of 7.8 to 8.0 , a temperature of $13.9^{\circ} \mathrm{C}$, a dissolved oxygen concentration of $0.5 \mathrm{mg} / \mathrm{L}$, and a conductivity of $328 \mu \mathrm{S} / \mathrm{cm}^{3}$ as determined by a DataSonde $4 /$ minisonde (Hydrolab Inc., Austin, TX). Control samples were obtained from Second Owsley on two occasions prior to the start of the field experiment so that 
background microbial community and urease characterizations could be compared to those obtained after the field experiment.

For the actual experiment, a straddle packer pump was placed in the open borehole to isolate the interval between 82.6 and $94.4 \mathrm{mbls}$ where the experiment would be confined. In order to stimulate the indigenous microbial communities, molasses (Grandma's Molasses, Riverton, NJ) and urea were added to the aquifer in $1000 \mathrm{~L}$ of groundwater that had previously been pumped from the Second Owsley well. Final concentrations of the molasses and urea were $0.1 \%$ and $30 \mathrm{mM}$, respectively. Potassium bromide was also added as a conservative tracer to determine the amount of the injected water that was retrieved. The added $\mathrm{Br}^{-}$ion equaled $5.3 \mathrm{mM}$ compared to background concentrations of $\mathrm{Br}^{-}$in the SRPA of approximately $0.0084 \mathrm{mM}$. Bromide concentrations were measured continuously using a combination sure flow bromide electrode (Model 9635BN, Thermo Orion, Beverly, MA) and an ionspecific meter (Model 290A, Orion, Beverly, MA).

Following the injection, the well was allowed to rest for 13 days. Subsequently, the well was pumped and sampled intermittently during the next 22 days until the concentration of bromide reached background levels. On any given sampling day the amount of water removed from the well was limited to $200 \mathrm{~L}$ to minimize the amount of urea and molasses solution that was recovered. Removing too much water on a single day would limit the downhole incubation period of the reactants. A total of about $3000 \mathrm{~L}$ of water was pumped from the aquifer during 15 sampling dates.

\section{Urease Activity of Bacillus pasteurii and SRPA Consortia}

The rates of urea hydrolysis by $B$. pasteurii (a constitutive urease producer and model microbe for calcite precipitation), by Escherichia coli (a microbe that is typically unable to hydrolyze urea), and by unenriched SRPA consortia were

determined using the tracer method with ${ }^{14} \mathrm{C}$-labeled urea (7). Briefly, B. pasteurii was grown at $26{ }^{\circ} \mathrm{C}$ in Brain Heart Infusion medium (Difco, Inc.) with $2 \%$ urea added for $48 \mathrm{~h}$. The grown cells were collected by centrifugation and washed three times using sterile synthetic groundwater. Using synthetic groundwater, the washed cell suspension was adjusted to an absorbance reading of 0.01 at $600 \mathrm{~nm}$, a turbidity equivalent to approximately $5 \times 10^{6}$ cells $/ \mathrm{mL}$ (L. Petzke, personal communication). E. coli was treated in the same manner except that it was originally grown in Trypticase Soy Broth (Difco, Inc.). SRPA consortia were obtained from UP-1, a research well located on the University Place, Idaho Falls campus of the University of Idaho and distant from Second Owsley. Total cell numbers in this consortium were approximately $1.3-1.7 \times 10^{4}$ cells $/ \mathrm{mL}$ of untreated groundwater ( $\mathrm{T}$. Tyler, unpublished data). 
A $256 \mu \mathrm{Ci} / \mathrm{mL}$ stock solution of ${ }^{14} \mathrm{C}$-urea $(7.7 \mathrm{mCi} / \mathrm{mmol}$, Sigma $)$ was prepared in sterile nanopure water. Nine milliliters of groundwater or washed $B$. pasteurii cell suspension were added to each $25-\mathrm{mL}$ flask and then amended with $5.9 \mathrm{nmol}{ }^{14} \mathrm{C}$-urea (equivalent to $100,000 \mathrm{dpm}$ ). Prior experiments suggested the need to add a carbon source along with the urea in order to stimulate urea hydrolysis in indigenous microbial communities. For the activity experiments described herein, we added $0.01 \%, 0.001 \%$, and $0.00075 \%$ molasses to the flasks containing groundwater consortia and $0.001 \%$ molasses to the flasks containing $B$. pasteurii. The $0.00075 \%$ molasses addition results in a final dissolved organic carbon (DOC) concentration that is just higher than the $1 \mathrm{mg} / \mathrm{L}$ DOC typically found in the SRPA. Negative controls, all with ${ }^{14} \mathrm{C}$-urea added, included groundwater with no added molasses, filtered $(0.2 \mu \mathrm{m}$ pore size $)$ groundwater with $0.001 \%$ molasses, and E. coli with $0.001 \%$ molasses. All experimental treatments were performed in triplicate series. Flasks were incubated at room temperature. For each series, ${ }^{14} \mathrm{C}-\mathrm{CO}_{2}$ was collected at 0,24 , or $48 \mathrm{~h}$ in order to collect rate data. Selection of unique populations within the groundwater samples during the incubation periods may have occurred but this was not measured.

Activity in the flasks was terminated by addition of $1 \mathrm{~mL} 2 \mathrm{~N} \mathrm{H}_{2} \mathrm{SO}_{4}$. The ${ }^{14} \mathrm{C}$-labeled $\mathrm{CO}_{2}$ produced from urea hydrolysis was collected on filter paper suspended in the flasks as previously described (8) except that $2 \mathrm{~N} \mathrm{NaOH}$ was used to collect the $\mathrm{CO}_{2}$. The amount of ${ }^{14} \mathrm{C}$-labeled urea that was converted to ${ }^{14} \mathrm{C}$-labeled $\mathrm{CO}_{2}$ was quantified using scintillation fluid (ScintiSafe Plus $50 \%$, Fisher Scientific) in a liquid scintillation counter (1220 Quantulus Wallac; Turku, Finland).

\section{Urease and Community Molecular Biology Studies of Snake River Plain Aquifer Microbes}

For molecular studies, microbial cells were filtered from Second Owsley groundwater through the course of the field experiment. At each sampling time, three separate $0.2 \mu \mathrm{m}$ capsule filters (Pall Gelman Laboratory, Ann Arbor, MI) were obtained, each containing cells filtered from $100 \mathrm{~L}$ of groundwater. The Second Owsley groundwater contains approximately $10^{5}$ cells $/ \mathrm{mL}$ (D. Cummings, personal communication); thus, approximately $10^{10}$ cells were adhered to each filter and available for the subsequent DNA extractions. Filters were stored frozen at $-80{ }^{\circ} \mathrm{C}$ prior to DNA extraction.

DNA from the capsule filters was extracted for whole community 16S rDNA and urease gene characterization using a modified sucrose lysis filter extraction method $(9,10)$. Briefly, $40 \mathrm{~mL}$ of lysis buffer $(20 \mathrm{mM}$ EDTA, $400 \mathrm{M} \mathrm{NaCl}, 50 \mathrm{mM}$ Tris, and $0.75 \mathrm{M}$ sucrose, $\mathrm{pH} 9), 4 \mathrm{~mL} \mathrm{10 \%} \mathrm{SDS,} \mathrm{and}$ 
$4 \mathrm{mg}$ Proteinase $\mathrm{K}$ were added to the capsule filter (previously thawed at $4{ }^{\circ} \mathrm{C}$ for $2 \mathrm{~h}$ ), incubated at $37^{\circ} \mathrm{C}$ for $2 \mathrm{~h}$ and then $55^{\circ} \mathrm{C}$ for $1 \mathrm{~h}$, rotating every $20 \mathrm{~min}$. The supernatant was extracted with chloroform, phenol:chloroform, and chloroform again. DNA was precipitated with sodium acetate and ethanol, and then resuspended in $10 \mathrm{mM}$ Tris-HCL $\mathrm{pH}$ 8.0.

In order to detect microbes in the aquifer that possess the ability to hydrolyze urea, we developed primers designed to amplify ure $\mathrm{C}$, a gene that codes for a conserved subunit of the urease enzyme. Several sets of PCR oligonucleotide primers were designed based on an alignment and phylogenetic analysis of known ure $\mathrm{C}$ genes from 44 bacterial species (11). A phylogenetic analysis was used to divide the sequences into three subgroups. All possible combinations of oligonucleotide primer pairs from each group were evaluated for their accuracy and specificity in PCR using DNA derived from several bacterial species belonging to each of the three subgroups identified. PCR products derived using the L2F/L2R primer pair having the predicted ca. 400 base pair length (Figure 2) were sequenced and found to have high similarity to known ureC sequences. Subsequent to these primer design studies, the L2F/L2R primer pair was used to determine the presence of urease genes in complex microbial communities collected from the SRPA before, during, and after the groundwater had been stimulated using molasses and urea in Second Owsley.

To determine changes in the aquifer microbial communities as a result of the molasses and urea amendments we used denaturing gradient gel electrophoresis (DGGE) of 16S rDNA gene fragments. Approximately $350 \mathrm{nt}$ fragments of the 16S rRNA gene were amplified by PCR genes using the bacterial-specific primers 338FGC (CGCCCGCCGCGCCCCGCGCCCGTCCCG CCGCCCCCGCCCTCCTACGGGAGGCAGCAG) and 690R (TCTACGCATTTCACC). PCR conditions were as follows: Promega PCR buffer-1X final, $2 \mathrm{mM} \mathrm{MgCl} 2,0.4 \%$ BSA, $0.2 \mathrm{mM}$ dntps, 20 pmol each primer, and $1 \mathrm{U}$ Promega Taq DNA polymerase. Thermal cycling conditions were as follows: $94^{\circ} \mathrm{C}, 5 \mathrm{~min}, 35$ cycles of $94^{\circ} \mathrm{C}, 30 \mathrm{~s}, 50^{\circ} \mathrm{C}, 30 \mathrm{~s}$, and $72^{\circ} \mathrm{C}, 60 \mathrm{~s}$, and a final incubation of $72{ }^{\circ} \mathrm{C}, 7 \mathrm{~min}$. Duplicate DNA extractions from each of the SRPA sampling time points (normalized to filtrate amount) were used as template. PCR products were separated on a $30-70 \%$ urea/formamide- $6 \%$ acrylamide gel and visualized with SYBR green (12). Bands with intensity changes between time points were selected for further analysis. DNA was eluted from the bands into $10 \mathrm{mM}$ Tris $\mathrm{pH} 8$ buffer. 16S rRNA gene fragments were amplified from this buffer using the primers $358 \mathrm{~F}$ (CTACGGGRGGCAGCAGTG) and 690R. PCR products were purified using the Ultraclean PCR cleanup kit (MoBio) and sequenced with the same primers using the Big Dye Terminator V.2 cycle sequencing kit (Applied Biosystems) according to the manufacturer's protocol. Sequences of complementary strands 

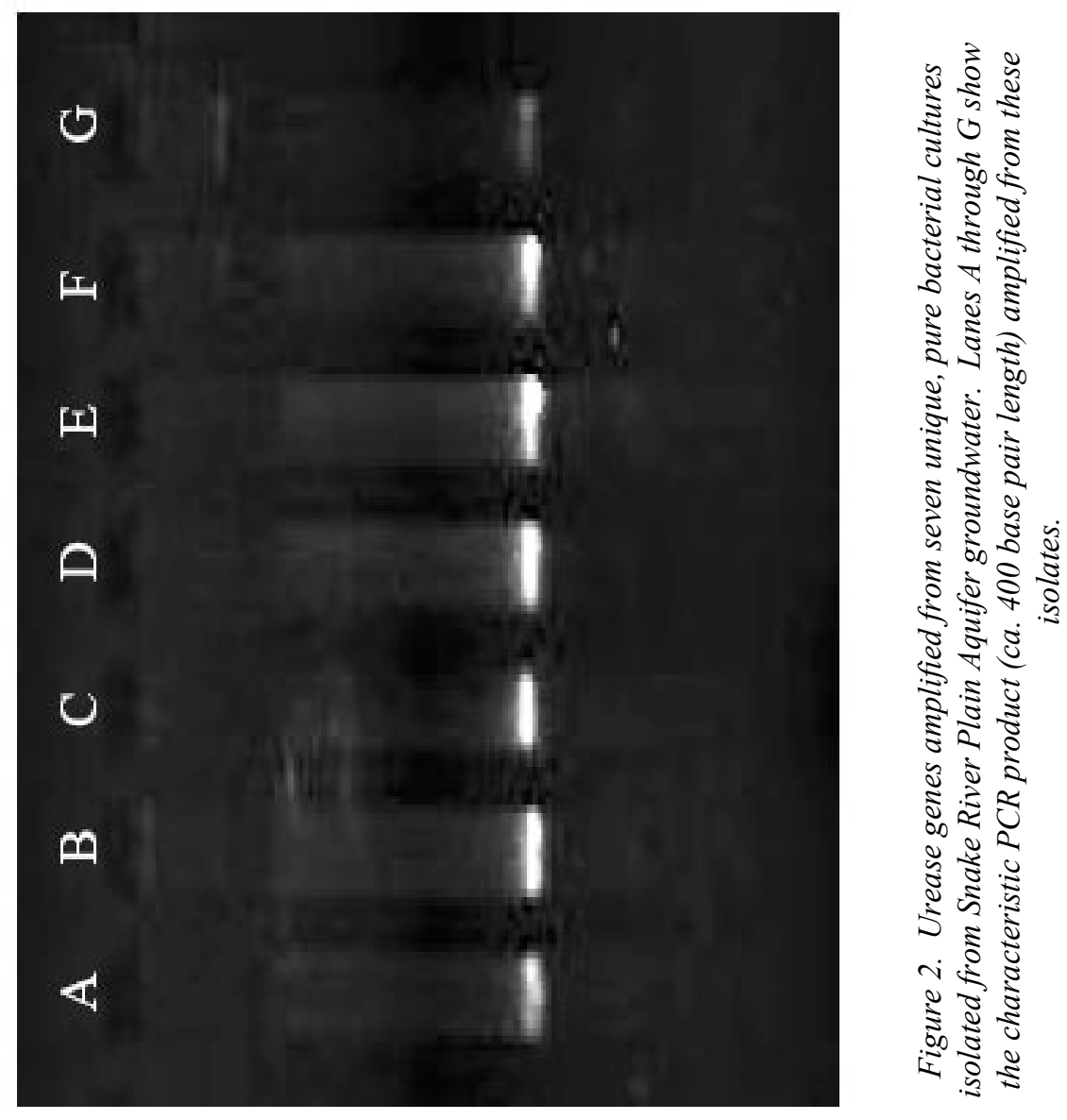
were assembled and edited using Autoassembler (Applied Biosystems). Sequences were compared to GenBank using BLAST.

\section{Modeling}

Scoping calculations that illustrate the coupling between urea hydrolysis and calcite precipitation for a groundwater system similar to the SRPA were conducted using the Geochemist Workbench (13), a commercially available geochemical reaction path computer code.

The aquifer conceptual model is a mixed equilibrium-kinetic system. Dissolution reactions involving aquifer host rock were assumed to be negligible relative to the time frames of the simulation and were ignored. Cation exchange reactions involving major groundwater cations and $\mathrm{NH}_{4}{ }^{+}$were assumed to be at equilibrium. Reactions other than the hydrolysis of urea that occurred within the groundwater phase were also assumed to be in equilibrium. Urea hydrolysis and calcite precipitation were both treated as kinetic reactions using rate laws as described below. First-order kinetics were used to describe urea hydrolysis. The rate constant was estimated from a measured rate of $0.6 \mathrm{mmol} / \mathrm{L} /$ day for groundwater amended with $50 \mathrm{mM}$ urea (unpublished data). Calcite precipitation was described using a second-order chemical affinity based rate law (14). The rate constant was estimated from the result of an aquifer-scale hydrochemistry evaluation of the SRPA (15). Using inverse modeling and a steady state assumption, McLing (15) estimated that $0.3 \mathrm{mmol} / \mathrm{L}$ of calcite precipitates over the approximately 50 years that groundwater traverses the SRPA beneath the Idaho National Engineering and Environmental Laboratory. To estimate the rate constant, a constant (saturation index of 0.06 ) but slight degree of supersaturation was assumed.

\section{Results and Discussion}

Experiments using ${ }^{14} \mathrm{C}$-labeled urea indicated that the microbes that make up the pristine SRPA communities possess considerable potential for urease activity under the correct conditions (Figure 3). Less than $6 \%$ of the ${ }^{14} \mathrm{C}$-labeled urea was metabolized in each of the treatments shown in Figure 3 indicating that the urea available to the cells for hydrolysis was probably not depleted in such a way that the rates would be altered. The highest rate of urea hydrolysis ( $>800 \mathrm{fmol}$ urea hydrolyzed $/ \mathrm{mL} / \mathrm{h}$ ) was noted for SRPA consortia that were supplemented with $0.01 \%$ molasses. The same consortia provided with less molasses $(0.001 \%$ and $0.00075 \%$ ) still showed marked urea hydrolysis (ca. 400 fmol urea hydrolyzed $/ \mathrm{mL} / \mathrm{h}$ ). These values are higher than those measured for $B$. pasteurii 


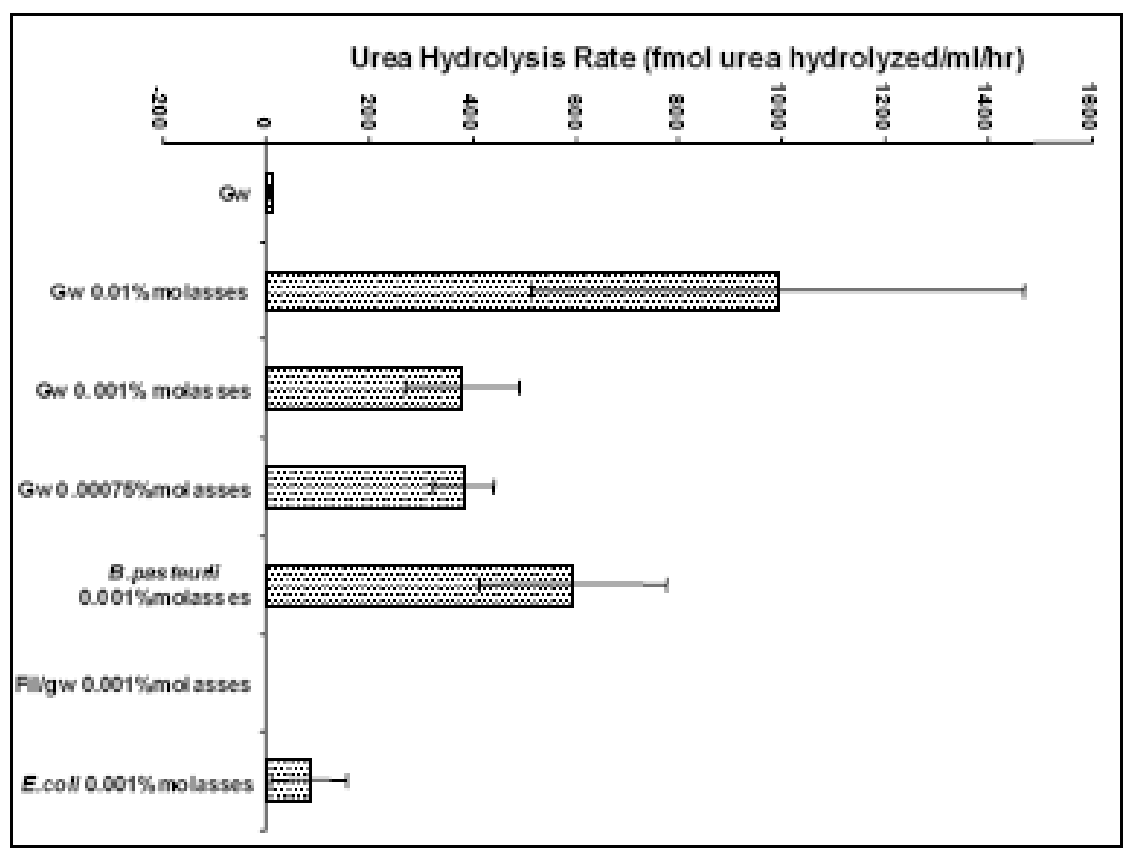

Figure 3. Mean urea hydrolysis rates for Snake River Plain Aquifer groundwater consortia provided with $0(\mathrm{GW}), 0.01 \%, 0.001 \%$, and $0.00075 \%$ molasses as a carbon source supplement along with $5.9 \mathrm{nmol}^{14} \mathrm{C}$-urea. For comparison, mean urea hydrolysis rates are also shown for B. pasteurii, E. coli, and filtered groundwater, all with $0.001 \%$ molasses. Each treatment was performed in triplicate, and error bars depict the standard deviation. 
provided the same amount of molasses. The concentration of cells in the B. pasteurii suspension is more than 300 times the concentration of cells in the SRPA consortia. This suggests that the specific activity of the aquifer microbes is higher than that of $B$. pasteurii under similar conditions. The control flasks with SRPA communities and no added molasses showed only trace levels of urea hydrolysis. This suggests the need to amend the indigenous SRPA microbial communities with a source of carbon in addition to the urea if urea hydrolysis is to be detected at any reasonable level. Cultures of $E$. coli showed some evidence of urea hydrolysis even though these cells are not supposed to be able to enzymatically cleave urea.

The ureC-specific PCR primer set $\mathrm{L} 2 \mathrm{~F} / \mathrm{L} 2 \mathrm{R}$ was tested with bacterial community DNA collected and extracted from Second Owsley groundwater samples. Samples for DNA analysis were taken throughout the course of a four week study during which molasses and urea were added to the subsurface in order to stimulate urease positive communities. The predicted ca. 400 base pair fragment of ureC was amplified from all of the samples regardless of whether they were obtained from the well before, during, and after the molasses/urea addition (Figure 4). Although the microbial communities obtained from the well prior to the experiment showed evidence of $u r e \mathrm{C}$, the bands associated with this gene appeared to be more intense following the molasses and urea treatment. No attempt was made to quantify ure C copy number in the samples and so we cannot say whether the treatment caused an increase in the number of these genes in the groundwater. Our results indicate that the primers designed to specifically amplify the ureC gene work on known urease positive isolates, including $B$. pasteurii, and also on microbial communities that are extracted from groundwater before and after aquifer treatments that are designed to stimulate urea hydrolysis by indigenous communities.

The results of the DGGE molecular analysis of the microbial community in Second Owsley indicate that there was a shift in community members as a result of the molasses and urea treatment (Figure 5). One microorganism (represented by Band A in Figure 5) was present throughout the sampling periods although the DNA bands corresponding to this microbe were most intense in samples acquired prior to the addition of molasses and urea. When the 16S rDNA sequence from this microbe was compared by BLAST to $16 \mathrm{~S}$ rDNA sequences in GenBank, it was $94 \%$ similar to sequences from known microbes in the Nitrospira group, specifically an uncultured clone "GOUTA19" (16). The Nitrospira group contains microbes that are chemolithotrophic nitrite-oxidizing bacteria (17) and some appear to be well adapted to low nitrite and oxygen concentrations (18). If ammonia resulting from urea hydrolysis was oxidized to nitrite then these bacteria could play a role in the conversion of nitrite to nitrate in the groundwater. One of the other prominent bands in the DGGE analysis (represented by Band B in Figure 5) had a 16S rDNA sequence that was most 


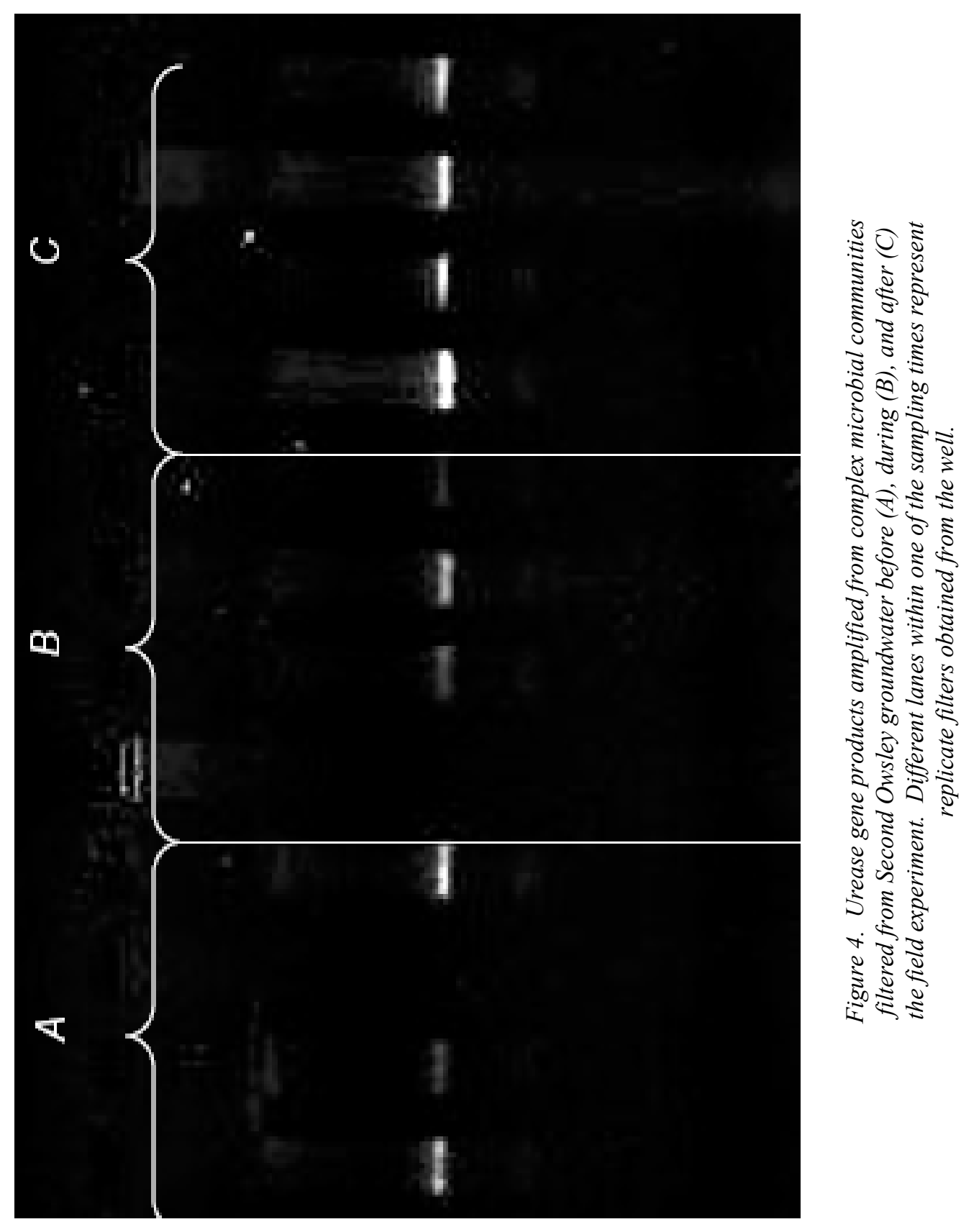




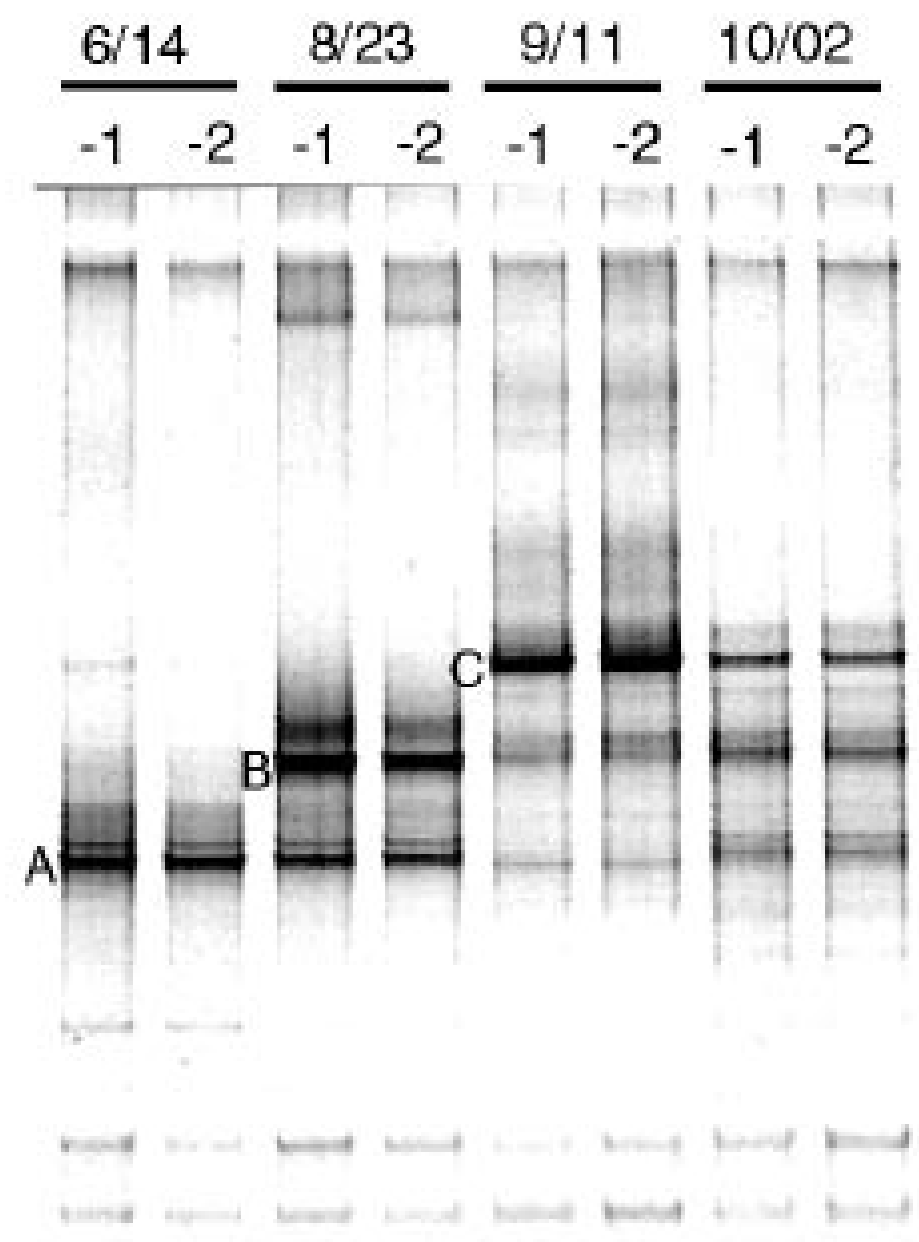

Figure 5. DGGE gel depicting $16 \mathrm{~S}$ rDNA sequences amplified from water samples taken before (6/14 and 6/23), during (9/11), and after (10/02) the Second Owsley experiment. Based on sequence similarity to GenBank entries, the microbes from which the three prominent bands $A, B$, and $C$ originated are most closely related to an uncultured bacterium, Pseudomonas putida, and Clostridium botulinum, respectively. "-1" and "-2" designations above the lanes indicate, respectively, undiluted and $2 x$ diluted DNA extract used in the experiment. 
closely related to that from Pseudomonas putida (99\% similarity). This microbe was not an evident member of the community during the first sampling time (6/14) but appeared subsequently in the Second Owsley groundwater (on 8/23) still prior to the amendments. This suggests that there is some variability in the pretreatment groundwater communities that may be controlled by factors of which we are unaware. Band $\mathrm{C}$ in Figure 5 contains a sequence that appears to be related to that of several microbes in the genus Clostridium, particularly Clostridium botulinum (99\% similarity). The sequence from this microbe was evident in samples taken on $6 / 14$ but not in samples taken on $8 / 23$. Following the addition of molasses and urea this microbe appeared to become a prominent member of the community before becoming less prominent on the 10/02 sampling point. Clostridia are all strict anaerobes, and the presence of Clostridia in the post treatment phase of the field experiment strongly suggests that our treatment caused the well to become even more anoxic than at the beginning of the study.

The evaluation of microbial responses to the molasses and urea additions to the aquifer at Second Owsley are an important aspect of our effort to track changes in the aquifer. These molecular tools are consistent with those recommended as being essential for determining whether bioremediation is occurring $(19,20)$. Ultimately, we hope to determine that ureC genes are actually being expressed (presence of mRNA that is specific to urease) as a way to confirm the activity of urease positive cells (21).

The results of a one-year kinetic simulation conducted using the Geochemist Workbench are presented in Figure 6. In this simulation, 10-mM urea was added to a representative groundwater. The groundwater $\mathrm{pH}$ was adjusted to an initial value of 7.3 so that the water was undersaturated with respect to calcite. The simulated aquifer had a porosity of $12 \%$ and a cation exchange capacity of $0.5 \mathrm{meq} / 100 \mathrm{~g}$, both of which are consistent with observations for the SRPA. All simulation results are for a closed system and based on $1 \mathrm{~kg}$ of water $(\sim 1 \mathrm{~L}$ of solutions) and $20 \mathrm{~kg}$ of aquifer matrix.

The simulation shows that the $\mathrm{pH}$ increased rapidly to a value of approximately 8.7 due to urea hydrolysis (Figure 6a). The $\mathrm{pH}$ then decreased when calcite precipitation began. Figure $6 \mathrm{~b}$ shows the behavior of some of the solution components. Urea decreased throughout the simulation in accordance with first-order kinetics. Initially, total $\mathrm{NH}_{4}^{+}, \mathrm{Ca}^{2+}$, and dissolved inorganic carbon (DIC expressed as $\mathrm{HCO}_{3}^{-}$) increased. Ammonium and DIC were released by urea hydrolysis. Exchange of $\mathrm{NH}_{4}{ }^{+}$ions for $\mathrm{Ca}^{2+}$ on cation exchange sites (Figure 6c) accounted for the increase in $\mathrm{Ca}^{2+}$ concentration. At longer times, calcium and DIC concentrations decreased and approached near constant values as calcite precipitated via the overall reaction:

$$
\mathrm{CO}\left(\mathrm{NH}_{2}\right)_{2}+2 \mathrm{H}_{2} \mathrm{O}+>\mathrm{X}_{2}: \mathrm{Ca}^{2+} \rightarrow \mathrm{CaCO}_{3}+2>\mathrm{X}^{2} \mathrm{NH}_{4}^{+}
$$



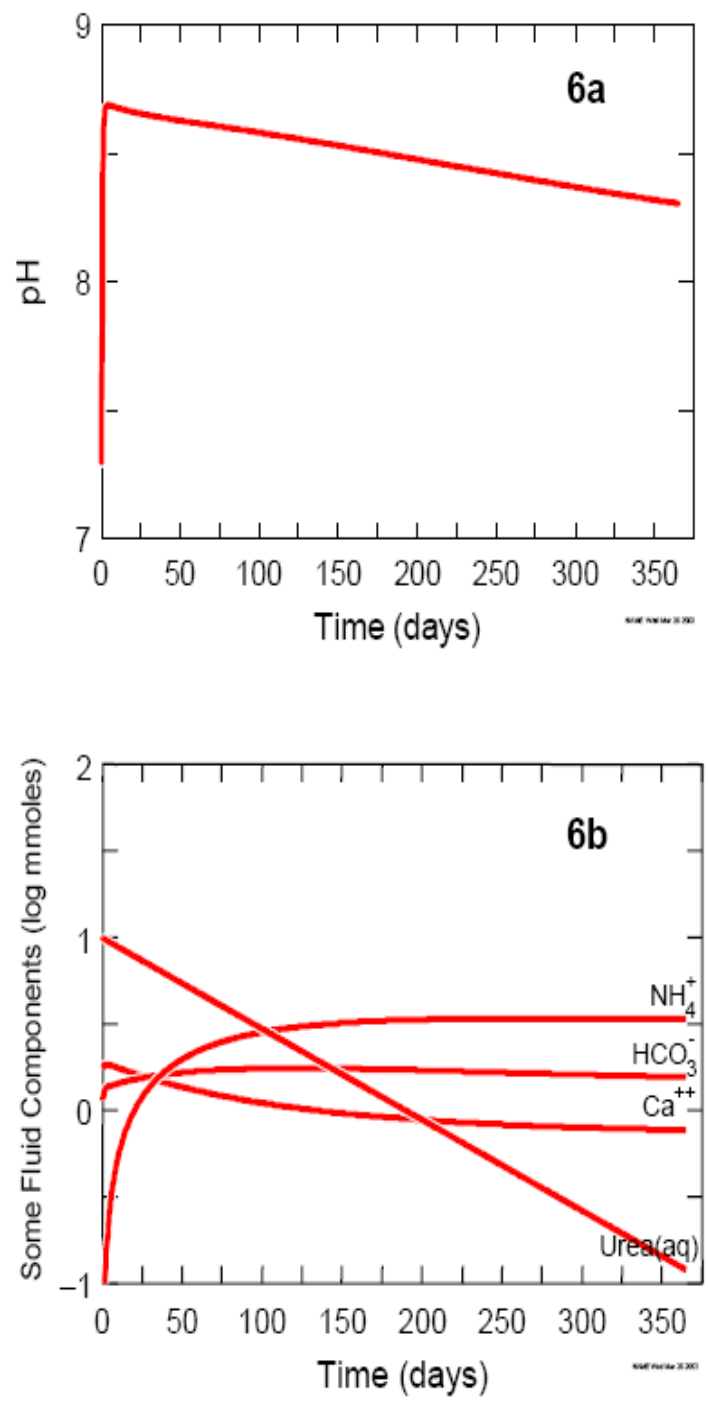

Figure 6. Results of a one-year kinetic simulation of urea hydrolysis for the Snake River Plain Aquifer. (a) pH. (b) Dissolved urea, dissolved inorganic carbon (as $\mathrm{HCO}_{3}^{-}$), calcium, and ammonium. (c) Amount of calcium and ammonium on aquifer matrix exchange sites. (d) Amount of calcite precipitated. 

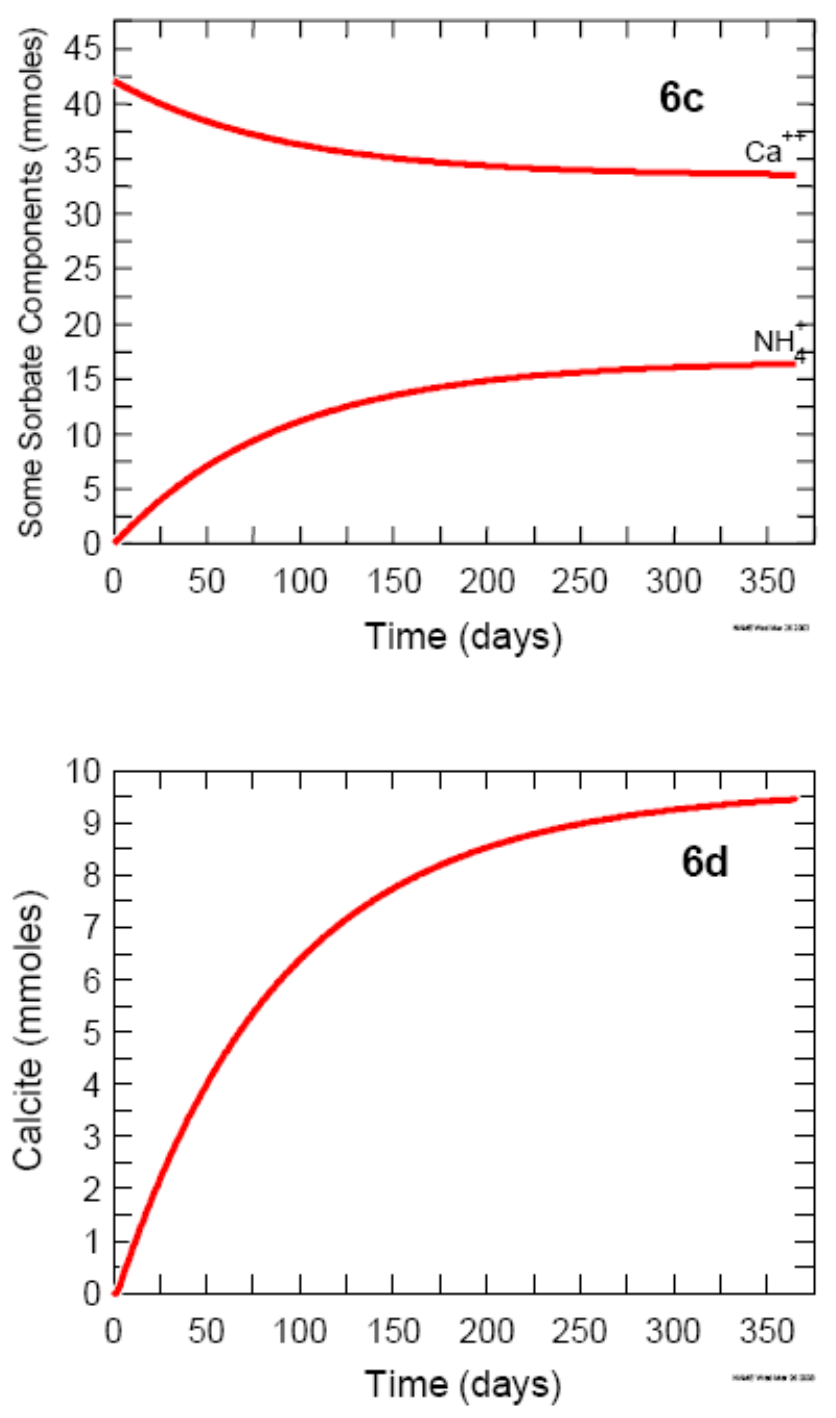

Figure 6. Continued. 
where $>\mathrm{X}_{2}: \mathrm{Ca}^{2+}$ and $>\mathrm{X}: \mathrm{NH}_{4}{ }^{+}$are cations on ion exchange sites. The stoichiometry of the above reactions suggests that as long as there is sufficient urea and $>\mathrm{X}_{2}: \mathrm{Ca}^{2+}$ is available in excess, the urea hydrolysis rate and the calcite precipitation rate should be the same. In fact for most of this simulation (days 2 through 285), the absolute value of the two rates was within $10 \%$ of each other. At longer time the urea was depleted causing decoupling of the precipitation of calcite and the hydrolysis of urea. In addition, the rates of both reactions decreased significantly (less than $5 \%$ of the maximum rate) as background aquifer conditions and processes were approached.

During the course of the simulation, almost $10 \mathrm{mmol}$ of calcite precipitated (Figure 6d) corresponding to the amount of urea initially present. It is important to note that only $1.75 \mathrm{mmol}$ of $\mathrm{Ca}^{2+}$ was present in the initial groundwater and at the end of the simulation there was $0.77 \mathrm{mmol}$ present in solution. This indicates that approximately $90 \%$ of the calcium in the precipitated calcite originated from calcium that was sorbed onto the aquifer matrix.

Although the simulation results presented here are not based on the results of field experiments, important generalizations regarding urea hydrolysis and calcite precipitation can be made using the simulation. First, because the rate constants used in this study are based on (as much as possible) pristine aquifer conditions, any engineered system that includes electron donor amendments at a contaminated location will likely be faster. Second, any application in the field would probably exhibit the three phases observed in this simulation, namely (1) urea hydrolysis rate greater than calcite precipitation rate, (2) calcite precipitation rate greater than urea hydrolysis rate, and (3) the two rates being equal. Third, the majority of the metals precipitated as carbonates will come from the aquifer matrix, not the groundwater. Fourth, during the period in which significant urea was available for hydrolysis, the entire hydrolysis-precipitation process can be described by a simple pseudo-first order kinetic model with the precipitation rate controlled by the urea hydrolysis rate and independent of the concentration of calcium in the groundwater.

In this paper we have presented results of investigations prerequisite to the use of calcite precipitation as a means to remove hazardous divalent cations (e.g. ${ }^{90} \mathrm{Sr}$ ) from groundwater. Our proposed method relies on the acceleration of calcite precipitation by encouraging aquifer microbes to hydrolyze urea and thereby increase the $\mathrm{pH}$ and alkalinity of the system. We have demonstrated that aquifer microbial communities possess the ability to hydrolyze urea at rates that are consistent with a known urea hydrolyzing microbe (B. pasteurii) and possibly even at higher rates under similar conditions. Community urea hydrolysis was most rapid when the cells were simultaneously provided with a source of organic carbon (molasses) as opposed to when no exogenous organic carbon was supplied. This suggests that field experiments may require an organic carbon amendment if reasonable rates of urea hydrolysis are to be 
expected. In order to trace the effect of accelerated calcite precipitation in the field, we designed ureC gene primer pairs in order to use PCR to detect the gene in environmental samples. We confirmed the efficacy of these primers with isolates from the Snake River Plain aquifer, one of the candidate aquifers for calcite precipitation-mediated remediation. Our molecular ecology experiments at an aquifer field site indicated that the complex microbial communities in this aquifer possess the ureC gene and that we can detect the gene in DNA extracts from free-living cells collected from the aquifer. Furthermore, using 16S rDNA studies we measured changes in the aquifer microbial community as a result of introducing molasses and urea in a preliminary test of our method. Because two distinct wells were used in these experiments the microbial communities in the two settings may have been different. Nevertheless, both of the wells access the same aquifer defined by fractured basalt geology and based on prior studies in the same aquifer (3), we believe that cells capable of urea hydrolysis are generally abundant in the SRPA.

A kinetic simulation of the microbial-facilitated calcite precipitation was conducted using geochemical conditions consistent with the SRPA, realistic concentrations of urea, and rates of microbial urea hydrolysis that are consistent with those measured on complex microbial communities. In the simulation, urea hydrolysis and then calcite precipitation proceeded at maximal rates. We expect that in a real field test of our process in which an electron donor (e.g., molasses) is added to the system to stimulate urea hydrolysis, the process would proceed even more rapidly. The modeling suggested that over the long periods that the process would occur in an aquifer, the precipitation rate would be controlled by the urea hydrolysis rates and would be independent of the concentration of calcium in the aquifer.

In future field experiments in which we will attempt to accelerate calcite precipitation, we will closely track the water chemistry of the aquifer during the experiment to determine whether calcite is precipitated. Our newly designed urease oligonucleotide primer sets will be used to quantify ureC gene copy number in groundwater samples using MPN-PCR or real-time PCR. Quantification of ureC gene copy number before, during, and after in situ urea amendment to groundwater will provide supporting evidence for the efficacy of this overall remediation approach by showing that we can increase the number of urea hydrolyzing bacteria. Use of $16 \mathrm{~S}$ rDNA community profiling over the course of a field experiment and beyond will provide data that can indicate how aquifer microbes change during the experiment and indicate the longevity of the changes in the community. These techniques will help to evaluate subsurface remediation of divalent cations (e.g., ${ }^{90} \mathrm{Sr}$ ) using this biogeochemical manipulation as a promising approach for arid western DOE sites such as Hanford and the Idaho National Engineering and Environmental Laboratory, where calcite precipitation is already an ongoing geochemical process. 


\section{Acknowledgments}

The DOE Environmental Management Science Program provided funding for this work. Research at the Idaho National Engineering and Environmental Laboratory is performed under the DOE Idaho Operations Office Contract DEAC07-99ID13727.

\section{References}

1. Riley, R. G.; Zachara, J. M.; Wobber, F. J. Chemical Contaminants on DOE Lands and Selection of Contaminant Mixtures for Subsurface Science Research; DOE/ER-0547T; U.S. Department of Energy, Office of Energy Research, Subsurface Science Program: Washington, DC, 1992.

2. National Research Council. In Situ Bioremediation. When Does it Work? National Academy Press: Washington, DC, 1993.

3. Fujita, Y.; Ferris, E. G.; Lawson, R. D.; Colwell, F. S.; Smith, R. W. Geomicrobiol. J. 2000, 17, 305-318.

4. Warren, L. A.; Maurice, P. A.; Parmar, N.; Ferris, F. G. Geomicrobiol. J. 2001, 18, 93-115.

5. Knutson, C. F.; McCormick, K. A.; Smith, R. P.; Hackett, W. P.; O'Brien, J. P.; Crocker, J. C. FY89 Report Radioactive Waste Management Complex vadose zone basalt characterization. 1990, EG\&G Idaho Report EGG-WM8949.

6. Morse, L. H.; McCurry, M. Genesis of Alteration of Quaternary Basalts within a Portion of the Eastern Snake River Plain Aquifer. In Geology, Hydrology, and Environmental Remediation; Link, P. K., and Mink, L. L., Eds.; Idaho National Engineering and Environmental Laboratory: Eastern Snake River Plain, Idaho, 2002; Special Paper 353; p 213-224.

7. Wright, R. T.; Hobbie, J. E. Ecology 1966, 47, 447-464.

8. Peters, G. T.; Colwell, F. S. Hydrobiologia 1989, 174, 79-87.

9. Britschgi, T. B.; Giovannoni, S. J. Appl. Environ. Microbiol. 1991, 57, 1313-1318.

10. Somerville, C. C.; Knight, I. T.; Straube, W. L.; Colwell, R. R. Appl. Environ. Microbiol. 1989, 55, 548-554.

11. Tyler, T. L.; Watwood, M. E.; Colwell, F. S. Characterization of Urease Genes in Subsurface Microbial Communities, Annual Meeting of the American Society for Microbiology, abstract, 2002.

12. Muyzer, G.; Hottentrager, S.; Teske, A.; Wawer, C. Denaturing Gradient Gel Electrophoresis of PCR-Amplified $16 \mathrm{~S}$ rDNA-A New Molecular Approach to Analyse the Genetic Diversity of Mixed Microbial 
Communities; Kluwer Academic Publishers: The Netherlands, 1996; Vol. 3.4.4, pp 1-23.

13. Bethke, C. M. The Geochemist's Workbench: A User's Guide to Rxn, Act2, Tact, React, and Gtplot; Release 4.0 ed.; Hydrogeology Program, University of Illinois: Urbana, IL, 2002.

14. Teng, H. H.; P.M., Dove; De Yoreo, J. J. Geochim. Cosmochim. Acta 2000, 64, 2255-2266.

15. McLing, T. L. The Pre-Anthropogenic Groundwater Evolution at the Idaho National Engineering Laboratory, Idaho; Idaho State University: Pocatello, ID, 1994; pp 62.

16. Alfreider, A.; Vogt, C.; Babel, W. Appl. Microbiol. 2002, 25, 232-240.

17. Teske, A.; Alm, E.; Regan, J. M.; Toze, S.; Rittmann, B. E.; Stahl, D. A. J. Bacteriol. 1994, 176, 6623-6630.

18. Loy, A.; Daims, H.; Wagner, M. Activated Sludge - Molecular Techniques for Determining Community Composition; Bitton, G., Ed.; Wiley: New York, 2002; Vol. 1, pp 26-43.

19. Madsen, E. L. Environ. Sci. Technol. 1991, 25, 1663-1673.

20. Madsen, E. L. Environ. Sci. Technol. 1998, 32, 429-439.

21. Wilson, M. S.; Bakermans, C.; Madsen, E. L. Appl. Environ. Microbiol. 1999, 65, 80-87. 


\section{Appendix B:}

Kinetics of calcite precipitation induced by ureolytic bacteria at 10 to 20 degrees $C$ in artificial groundwater.

By F.G. Ferris, V. Phoenix, Y. Fujita, and R.W. Smith.

In Geochimican et Cosmochimica Acta. 68:1701-1710 (2004). 


\title{
doi:10.1016/S0016-7037(00)00503-9
}

\section{Kinetics of calcite precipitation induced by ureolytic bacteria at 10 to $20^{\circ} \mathrm{C}$ in artificial groundwater}

\author{
F. G. Ferris, ${ }^{1} *$ V. Phoenix, ${ }^{1}$ Y. Fujtta,${ }^{2}$ and R. W. Smith $^{3}$ \\ ${ }^{1}$ Department of Geology, University of Toronto, 22 Russell Street, Toronto, Ontario, Canada, M5S 3B1 \\ ${ }^{2}$ Biotechnology Department, Idaho National Engineering and Environmental Laboratory, P.O. Box 1625, Idaho Falls, ID 83415-2107, USA \\ ${ }^{3}$ Biological and Agricultural Engineering Department, University of Idaho-Idaho Falls, Idaho Falls, ID 83402, USA
}

(Received February 17, 2003; accepted in revised form June 18, 2003)

\begin{abstract}
The kinetics of calcite precipitation induced in response to the hydrolysis of urea by Bacillus pasteurii at different temperatures in artificial groundwater (AGW) was investigated. The hydrolysis of urea by $B$. pasteurii exhibited a temperature dependence with first order rate constants of $0.91 \mathrm{~d}^{-1}$ at $20^{\circ} \mathrm{C}, 0.18$ $\mathrm{d}^{-1}$ at $15^{\circ} \mathrm{C}$, and $0.09 \mathrm{~d}^{-1}$ at $10^{\circ} \mathrm{C}$. At all temperatures, the $\mathrm{pH}$ of the $\mathrm{AGW}$ increased from 6.5 to 9.3 in less than $1 \mathrm{~d}$. Dissolved $\mathrm{Ca}^{2+}$ concentrations decreased in an asymptotic fashion after $1 \mathrm{~d}$ at $20^{\circ} \mathrm{C}$ and $15^{\circ} \mathrm{C}$, and $2 \mathrm{~d}$ at $10^{\circ} \mathrm{C}$. The loss of $\mathrm{Ca}^{2+}$ from solution was accompanied by the development of solid phase precipitates that were identified as calcite by X-ray diffraction. The onset of calcite precipitation at each temperature occurred after similar amounts of urea were hydrolyzed, corresponding to $8.0 \mathrm{mM} \mathrm{NH}{ }_{4}^{+}$. Specific rate constants for calcite precipitation and critical saturation state were derived from time course data following a second-order chemical affinity-based rate law. The calcite precipitation rate constants and critical saturation states varied by less than $10 \%$ between the temperatures with mean values of $0.16 \pm 0.01 \mu$ moles $\mathrm{L}^{-1} \mathrm{~d}^{-1}$ and $73 \pm 3$, respectively. The highest calcite precipitation rates (ca. $0.8 \mathrm{mmol} \mathrm{L}^{-1} \mathrm{~d}^{-1}$ ) occurred near the point of critical saturation. While unique time course trajectories of dissolved $\mathrm{Ca}^{2+}$ concentrations and saturation state values were observed at different temperatures, calcite precipitation rates all followed the same asymptotic profile decreasing with saturation state regardless of temperature. This emphasizes the fundamental kinetic dependence of calcite precipitation on saturation state, which connects the otherwise dissimilar temporal patterns of calcite precipitation that evolved under the different temperature and biogeochemical regimes of the experiments. Copyright (C) 2003 Elsevier Ltd
\end{abstract}

\section{INTRODUCTION}

In many surface and near-surface hydrogeochemical environments, the precipitation of calcite is mediated by metabolically active bacteria both through affecting an increase in saturation state and by serving as heterogeneous nucleation substrates for mineral formation (Fortin et al., 1997). The ability of bacteria to induce the formation of calcite is the key to a recently suggested bioremediation approach for aquifers in the western United States (Fujita et al., 2000; Warren et al., 2001), particularly where Department of Energy (DOE) operations have left groundwater contaminated with divalent metals or radionuclides (Riley and Zachara, 1992). Although pure carbonate phases may precipitate at high contaminant concentrations, at lower concentrations varying amounts of contaminant metals (e.g., $\mathrm{Pb}, \mathrm{Zn}, \mathrm{Ba}, \mathrm{Cd}$ ) and radionuclides (e.g., ${ }^{90} \mathrm{Sr}$, ${ }^{60} \mathrm{Co}$ ) can be immobilized in calcite through coprecipitation. The rate at which trace metals are incorporated into calcite is a function of precipitation kinetics, the adsorption interactions between the calcite surface and the trace metal in solution (Zachara et al., 1991), and the solid solution properties of the trace metal in calcite (Tesoriero and Pankow, 1996)).

Previous studies have established that calcite precipitation is an important process affecting groundwater chemistry at arid western sites, including the Snake River Plain Aquifer (SRPA) both regionally (Wood and Low, 1986) and locally at the DOE

* Author to whom correspondence should be addressed (ferris@geology.utoronto.edu).
Idaho National Engineering and Environmental Laboratory (Knobel et al., 1992). Furthermore, detailed investigations of SRPA calcite that were deposited in the vadose zone and now reside below the water table suggest calcite is stable for 10000 to $100000 \mathrm{yr}$, and that waste disposal activities have resulted in continued calcite precipitation (Tobin, 2000). These observations make the use of bacterial calcite precipitation to capture and immobilize contaminant radionuclides an attractive bioremediation strategy.

The production of ammonia and dissolved inorganic carbon (DIC) during decomposition of nitrogen-rich organic compounds by bacteria tends to increase both $\mathrm{pH}$ and alkalinity, which favor calcite precipitation (Ferris et al., 1996). Bacterial enzymatic hydrolysis of urea in particular is a promising option for in situ manipulation and acceleration of calcite precipitation rates (Fujita et al., 2000; Warren et al., 2001). The hydrolysis of urea in the presence of ureolytic bacteria proceeds according to the reaction:

$$
\mathrm{NH}_{2} \mathrm{CONH}_{2}+2 \mathrm{H}_{2} \mathrm{O}=2 \mathrm{NH}_{4}^{+}+\mathrm{CO}_{3}^{-}
$$

The reaction is catalyzed by urease, a heteropolymeric nickeldependent metalloenzyme, with a rate approximately $10^{14}$ times faster than the uncatalyzed rate (Jarbi et al., 1995; Benini et al., 1996). Production of urease allows bacteria to make use of urea as a nitrogen source (Nielsen et al., 1998; Swensen and Bakken, 1998) with evolved ammonium and carbonate (i.e., $\mathrm{NH}_{3}+\mathrm{H}^{+}=\mathrm{NH}_{4}{ }^{+}$and $\mathrm{CO}_{3}{ }^{2-}+\mathrm{H}^{+}=\mathrm{HCO}_{3}{ }^{-}$) buffering the acidity that stems from cell growth (Clancy and Burne, 1997). There is also some evidence that urea hydrolysis con- 
tributes to energy metabolism by promoting proton translocation across the cytoplasmic membrane with concomitant synthesis of ATP (Smith et al., 1993; Jahns, 1996).

Urea is an important organic nitrogen carrier in natural environments, and is commonly used as an agricultural fertilizer (Gillman et al., 1995; Nielsen et al., 1998). The ability to hydrolyze urea is widely distributed among indigenous bacteria present in soils and groundwater environments (Swensen and Bakken, 1998; Fujita et al., 2000). Because of these attributes, bacterial hydrolysis of urea has been adapted to actively precipitate carbonates as mineral plugging and cementing agents in porous geological media (Ferris and Stehmeier, 1992; Ferris et al., 1996; Stocks-Fisher et al., 1999). Bioremediation using ureolytic bacteria to cause an increase in $\mathrm{pH}$ is additionally preferable to direct addition of a basic solution because the gradual hydrolysis of urea is likely to promote a wider spatial distribution of calcite precipitation in the subsurface than the direct addition of base, which in contrast is likely to cause immediate precipitation only in the borehole.

There are numerous reports on bacterial precipitation of calcite and other carbonate minerals (Thompson and Ferris, 1990; Pentecost and Spiro, 1990; Ferris et al., 1994, 1995, 1996; Schultze-Lam and Beveridge, 1994; Fortin et al., 1997; Stocks-Fisher et al., 1999). Few of these studies have been conducted under circumstances that simulate or approach in situ conditions, and even fewer have specifically addressed precipitation kinetics. The goal of this study is to explore the kinetics of calcite precipitation induced by ureolytic bacteria in artificial SRPA groundwater. A fundamental dependence of bacterial induced calcite precipitation rates on saturation state, as anticipated by conventional chemical affinity-based rate laws (Teng et al., 2000), is demonstrated by taking into account the kinetics and temperature dependence of urea hydrolysis.

\section{MATERIALS AND METHODS}

\subsection{Growth and Preparation of Bacteria}

A pure culture of the gram-positive, spore-forming, urease positive bacteria Bacillus pasteurii (ATCC 11859) was used in this investigation to induce calcite precipitation in response to urea hydrolysis. The urease deficient species Bacillus subtilis 168 was used as a negative control. For experimental work, the bacteria were grown overnight at $30^{\circ} \mathrm{C}$ in Brain Heart Infusion broth supplemented with $2 \%(w / v)$ urea and harvested by centrifugation at $8500 \mathrm{~g}$ for $10 \mathrm{~min}$. After being washed twice in sterile ultra pure water (UPW) by centrifugation, cells were suspended in sterile UPW at an optical density of 0.14 at $600 \mathrm{~nm}$. These cell suspensions were subsequently used to inoculate the calcite precipitation experiments.

\subsection{Calcite Precipitation Experiments}

An artificial groundwater (AGW) medium was prepared in UPW based on the aqueous chemistry of the Snake River Plain Aquifer (SRPA) in the vicinity of the Idaho National Engineering and Environmental Laboratory, Idaho Falls, USA. Major anion and cation concentrations were representative of values from historical records of SRPA water quality (Knobel et al., 1992). Specific inorganic chemical constituents of the AGW included $\mathrm{KNO}_{3}(0.0403 \mathrm{mM}), \mathrm{MgSO}_{4}(0.448$ $\mathrm{mM}), \mathrm{CaCl}_{2}(1.75 \mathrm{mM}), \mathrm{NaNO}_{3}(0.044 \mathrm{mM}), \mathrm{NaHCO}_{3}(1.1 \mathrm{mM})$, and $\mathrm{KHCO}_{3}(0.0623 \mathrm{mM})$ to give an ionic strength of $0.01 \mathrm{~mol} / \mathrm{L}$. Organic carbon concentrations in pristine regions of the aquifer are generally less than $0.1 \mathrm{mmol} \mathrm{C} / \mathrm{L}$ (Knobel et al., 1992), so apart from the addition of $6.0 \mathrm{mM}$ urea (for $20^{\circ} \mathrm{C}$ experiments) and $25 \mathrm{mM}$ urea (for 10 and $15^{\circ} \mathrm{C}$ experiments), no organic carbon was added to the medium.

The AGW medium was initially constituted at double strength to be mixed in equal parts with the washed bacterial suspensions. Because a natural $\mathrm{pH}$ near 8.0 leaves SRPA groundwater close to saturation with respect to calcite (Knobel et al., 1992), the double strength AGW pH was adjusted to 6.5 with $1.0 \mathrm{~N} \mathrm{HCl}$ to avoid premature calcite precipitation. Sterilization of the double strength AGW was accomplished by filtration through autoclaved $0.2-\mu \mathrm{m}$-pore-size filters. Then $150 \mathrm{~mL}$ volumes were dispensed into autoclaved $500 \mathrm{~mL}$ glass bottles and inoculated with an equal volume of washed B. pasteurii suspension to give a final $\mathrm{OD}_{600}$ of 0.07 . Separate sets of bottles were inoculated with B. subtilis, or amended with sterile UPW, to serve as negative biotic and chemical controls, respectively. All experiments were run in triplicate with static incubation at $20^{\circ} \mathrm{C}, 15^{\circ} \mathrm{C}$ and $10^{\circ} \mathrm{C}$ for periods of $7 \mathrm{~d}$.

\subsection{Chemical and Mineralogical Analyses}

The changes in water chemistry including $\mathrm{pH}$, ammonium, dissolved magnesium, and dissolved calcium were analyzed at 1 to $2 \mathrm{~d}$ intervals during the experiments. The $\mathrm{pH}$ was measured using a Corning Model $250 \mathrm{pH}$ meter equipped with a Ross Sure-Flow combination electrode. Ammonium produced from the hydrolysis of urea by $B$. pasteurii during the experiment was determined by the Nessler method using a HACH DR-2000 spectrophotometer. Samples after being filtered through $0.2-\mu \mathrm{m}$ filters were analyzed for changes in dissolved calcium concentrations using a Perkin-Elmer 4000 flame atomic absorption spectrophotometer. Mineral precipitates that formed during incubation were collected at the end of the $7 \mathrm{~d}$ experiments, and identified by powder X-ray diffraction (XRD) using a Philips XRD system with a PW1830 HT generator, PW1050 goniometer, and PW3710 control unit. Samples were analyzed using $\mathrm{Cu} \mathrm{K} \alpha$ radiation, a step size of 0.020 at a rate of $0.85 \mathrm{~s} / \mathrm{step}$ from $2 \theta$ of $4^{\circ}$ to $90^{\circ}$.

\subsection{Kinetic Relationships and Data Analyses}

The hydrolysis of urea, as shown in Eqn. 1, gives rise to a mechanistic first order rate expression:

$$
\frac{d[\text { urea }]}{d t}=-k_{\text {urea }}[\text { urea }]
$$

Integration yields

$$
[\text { urea }]_{t}=[\text { urea }]_{0} e^{-k_{\text {ureat }}}
$$

where $[u r e a]_{t}$ is the concentration of urea remaining at time $t$, and [urea $_{0}$ is the initial urea concentration at $t=0$. Considering the stoichiometry of the reaction for urea hydrolysis (Eqn. 1), the amount of urea hydrolyzed at time $t$ is equivalent to one half of the corresponding dissolved $\mathrm{NH}_{4}{ }^{+}$concentration $\left[\mathrm{NH}_{4}{ }^{+}\right]_{t}$ Thus, the concentration of urea remaining at ${ }_{t}$ is described by the mass balance expression:

$$
[\text { urea }]_{t}=[\text { urea }]_{0}-\frac{1}{2}\left[\mathrm{NH}_{4}^{+}\right]_{t}
$$

Combining Eqns. 3 and 4 relates $\left[\mathrm{NH}_{4}^{+}\right]_{t},[\text { urea }]_{0}$, and $k_{\text {urea }}$ in a function permissive to the estimation of urea hydrolysis rate constants $\left(k_{\text {urea }}\right)$ from experimental measurements of dissolved $\mathrm{NH}_{4}{ }^{+}$concentrations over time:

$$
\left[\mathrm{NH}_{4}^{+}\right]_{t}=2[\text { urea }]_{0}\left(1-e^{-k_{\text {ureat }}}\right)
$$

The saturation state $(S)$ of a solution with respect to calcite is conventionally defined by:

$$
S=\frac{\left\{\mathrm{Ca}^{2+}\right\}\left\{\mathrm{CO}_{3}{ }^{2-}\right\}}{K_{S O}}
$$

where $\left\{\mathrm{Ca}^{2+}\right\}$ and $\left\{\mathrm{CO}_{3}{ }^{2-}\right\}$ represent the activities of dissolved $\mathrm{Ca}^{2+}$ and $\mathrm{CO}_{3}{ }^{2-}$, respectively, and $K_{\mathrm{so}}$ is the equilibrium calcite solubility product. Experimental $S$ values were calculated using the extended Debye-Hückel equation to determine activities of dissolved $\mathrm{Ca}^{2+}$ and $\mathrm{CO}_{3}{ }^{2-}$, with the corresponding $K_{s o}$ for each experimental temperature (Stumm and Morgan, 1996). Measured dissolved $\mathrm{Ca}^{2+}$ concentrations were used for the calculations, whereas $\mathrm{CO}_{3}{ }^{2-}$ concentrations were 
necessarily derived from speciation of the total dissolved inorganic carbon $\left(C_{T}\right)$ in solution:

$$
\left[\mathrm{CO}_{3}^{2-}\right]=\alpha_{2} C_{T}
$$

where the mole fraction $\left(\alpha_{2}\right)$ of $\mathrm{CO}_{3}{ }^{2-}$ is (Stumm and Morgan, 1996):

$$
\alpha_{2}=\left(\frac{\left[H^{+}\right]^{2}}{K_{1} K_{2}}+\frac{\left[H^{+}\right]}{K_{2}}+1\right)^{-1}
$$

The corresponding acidity constants $K_{1}$ and $K_{2}$ for each experimental temperature are given by Stumm and Morgan (1996), with $\left[\mathrm{H}^{+}\right]$ determined from measured $\mathrm{pH}$.

In the experiments, dissolved $C_{T}$ concentrations changed over time according to the mass balance relationship:

$$
C_{T}=C_{\text {Tinitial }}+C_{\text {Turea }}-C_{\text {Tcalcite }}
$$

where $\mathrm{C}_{\text {Tinitial }}$ equals the initial dissolved inorganic carbon concentration in the AGW, $\mathrm{C}_{\text {Turea }}$ is the dissolved inorganic carbon produced from urea hydrolysis (i.e., [urea $]_{0}-[\text { urea }]_{t}$ calculated using Eqns. 4 and 5 after determination of kurea), and $\mathrm{C}_{\text {Tcalcite }}$ is the dissolved inorganic carbon removed from solution owing to calcite precipitation (i.e., $\left[\mathrm{Ca}^{2+}\right]_{0}-\left[\mathrm{Ca}^{2+}\right]_{t}$ calculated using measured dissolved $\mathrm{Ca}^{2+}$ concentrations).

Following the onset of calcite precipitation from a saturated solution, the decrease in $S$ with respect to time is anticipated from mass action to be:

$$
\frac{d S}{d t}=-k_{s}\left(\frac{\left\{\mathrm{Ca}^{2+}\right\}\left\{C \mathrm{CO}_{3}^{2-}\right\}}{K_{S O}}\right)=-k_{S} S
$$

Integration yields:

$$
S_{t}=S_{0} e^{-k_{s} t}
$$

where $S_{t}$ is the saturation index at time $t, S_{0}$ is the apparent saturation index expected if precipitation started at $t=0$, and $k_{S}$ is a first order rate constant. In turn, the rate of $\mathrm{Ca}^{2+}$ precipitation in calcite is described by the kinetic relationship (Teng et al., 2000):

$$
\frac{d\left[\mathrm{Ca}^{2+}\right]}{d t}=-k_{p}(S-1)^{2}
$$

The kinetics of calcite precipitation has been investigated using a number of different approaches to interpret changes in solution composition data during crystal growth (Teng et al., 2000). Of the various kinetic models that have been advanced, nonlinear rate laws dependent on saturation state (i.e., affinity-based), such as the quadratic expression illustrated by Eqn. 12, are widely used at both ambient and elevated temperatures for nonequilibrium (i.e., $\mathrm{S}>2$ ) conditions (Reddy and Nancollar, 1971; House, 1981; Shiraki and Brantley, 1995; Zhang and Dawe, 1998; Zuddas and Mucci, 1998).

Combining Eqns. 10 and 12 yields:

$$
\frac{d\left[\mathrm{Ca}^{2+}\right]}{d S}=\frac{k_{P}(S-1)^{2}}{k_{S} S}=\frac{k_{P} S}{k_{S}}-\frac{2 k_{P}}{k_{S}}+\frac{k_{P}}{k_{S} S}
$$

The integral of Eqn. 13 becomes:

$$
\int_{\text {Casi }}^{\text {Cas }} d\left[\mathrm{Ca}^{2+}\right]=\frac{k_{P}}{k_{S}} \int_{S_{\text {critical }}}^{S} S d S-\frac{2 k_{P}}{k_{S}} \int_{S_{\text {critical }}}^{S} d S+\frac{k_{P}}{K_{S}} \int_{S_{\text {critical }}}^{S} \frac{d S}{S}
$$

Integration yields:

$$
\begin{aligned}
{\left[\mathrm{Ca}^{2+}\right]_{S}=\left(\frac{k_{P}}{k_{S}}\right)\left[S\left(\frac{S}{2}-2\right)-\right.} & S_{\text {critical }}\left(\frac{S_{\text {critical }}}{2}-2\right) \\
& \left.+\ln \left(\frac{S}{S_{\text {critical }}}\right)\right]+\left[\mathrm{Ca}^{2+}\right]_{\text {critical }}
\end{aligned}
$$

where $S_{\text {critical }}$ is the critical supersaturation at which calcite precipitation actually begins, and $\left[\mathrm{Ca}^{2+}\right]_{\text {Scritical }}$ is the dissolved $\mathrm{Ca}^{2+}$ concen- tration at $S_{\text {critical }}$, which is equivalent to the initial concentration of dissolved $\mathrm{Ca}^{2+}$ at time zero. To reduce the parameterization of Eqn. 15 to estimate $S_{\text {critical }}$ and $k_{p}$, values for $k_{S}$ were first determined independently (as described below) using Eqn. 11.

The experimental data was fit to integrated equations for urea hydrolysis (Eqn. 5), saturation state (Eqn. 11) and dissolved calcium concentrations (Eqn. 15) using unconstrained nonlinear regression and a quasi-Newton optimization routine for parameter estimation (STATISTICA $\vee 5.0$ ). Tests for false local minima were performed by varying the initial parameter estimates. The result with the highest correlation coefficient (i.e., $\mathrm{r}^{2}$ value) was accepted as the global minimum for the residual variance (i.e., sum of squared residuals) about the regression line. All analyses converged to the same final result, regardless of the initial parameter estimates, as expected for optimal minimization of the deviation between observed experimental and predicted values.

\section{RESULTS}

The production of ammonium over time from the hydrolysis of urea by B. pasteurii at different temperatures in artificial groundwater is shown in Figure 1 . At $20^{\circ} \mathrm{C}$, most of the urea present at an initial concentration of $6.0 \mathrm{mM}$ was subjected to hydrolysis and consumed within $7 \mathrm{~d}$ to limit ammonium production stoichiometrically to $12 \mathrm{mM}$ (i.e., $2 \mathrm{~mol} \mathrm{NH}_{4}^{+}$produced per mole of urea). Sustained ammonium production occurred at both 15 and $10^{\circ} \mathrm{C}$ when urea was incorporated into the artificial groundwater at an initial concentration of $25 \mathrm{mM}$; however, the total amount of ammonium produced over $7 \mathrm{~d}$ at $15^{\circ} \mathrm{C}$. $(35 \mathrm{mM})$ was almost double that which was produced at $10^{\circ} \mathrm{C}(20 \mathrm{mM})$. In terms of stoichiometric equivalents, approximately two-thirds of the available urea was hydrolyzed at $15^{\circ} \mathrm{C}$, whereas only one third was hydrolyzed at $10^{\circ} \mathrm{C}$. No ammonium was produced in the abiotic control (i.e., in the absence of bacteria), or in the negative control containing $B$. subtilis (i.e., bacteria incapable of hydrolyzing urea).

The first order kinetic expression expected for urea hydrolysis by B. pasteurii (Eqn. 5) yielded individual curves with correlation coefficients in excess of 0.90 (Fig. 1). Corresponding rate constants determined from the nonlinear optimization analyses of the experimental data are shown in Table 1, and exhibit a pronounced temperature dependence. Specifically, the urea hydrolysis rate constant $\left(k_{\text {urea }}\right)$ effective at $20^{\circ} \mathrm{C}(0.91$ $\left.\mathrm{d}^{-1}\right)$ was found to be 5 times greater than $k_{\text {urea }}$ at $15^{\circ} \mathrm{C}(0.18$ $\left.\mathrm{d}^{-1}\right)$, and 10 times greater than $k_{\text {urea }}$ at $10^{\circ} \mathrm{C}\left(0.09 \mathrm{~d}^{-1}\right)$. The initial $(\mathrm{t}=0)$ urea hydrolysis rates calculated in accordance with Eqn. 2 display a similar pattern of temperature dependence, ranging from a high value of $5.5 \mathrm{mmol} \mathrm{L}^{-1} \mathrm{~d}^{-1}$ at $20^{\circ} \mathrm{C}$ to a low of $2.2 \mathrm{mmol} \mathrm{L}^{-1} \mathrm{~d}^{-1}$ at $10^{\circ} \mathrm{C}$ (Fig. 1d). This apparent correlation with temperature was obscured quite rapidly as dissimilar urea hydrolysis rate profiles evolved over time in response to the different rate constants and initial urea concentrations. After only $1 \mathrm{~d}$, the rate of urea hydrolysis at $20^{\circ} \mathrm{C}$ had fallen below the $15^{\circ} \mathrm{C}$ rate to a level equivalent with the rate at $10^{\circ} \mathrm{C}$. The $20^{\circ} \mathrm{C}$ rates continued to decline rapidly with urea hydrolysis nearing completion after $5 \mathrm{~d}$. At the same time, a lesser decline in urea hydrolysis rates occurred at the two lower temperatures leading to a convergence of rate values near 1.6 mmol L ${ }^{-1} \mathrm{~d}^{-1}$ after $7 \mathrm{~d}$.

The production of ammonium and carbonate from the hydrolysis of urea by B. pasteurii (Eqn. 1) at all temperatures increased the $\mathrm{pH}$ of the AGW medium to 9.3 in less than $1 \mathrm{~d}$. This is consistent with a rapid onset of $\mathrm{NH}_{4}{ }^{+}=\mathrm{NH}_{3}+\mathrm{H}^{+}$and 
(a)

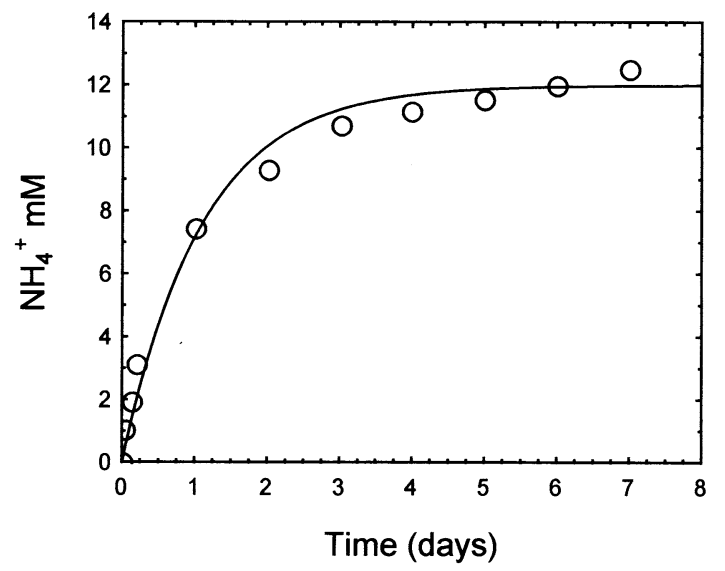

(c)

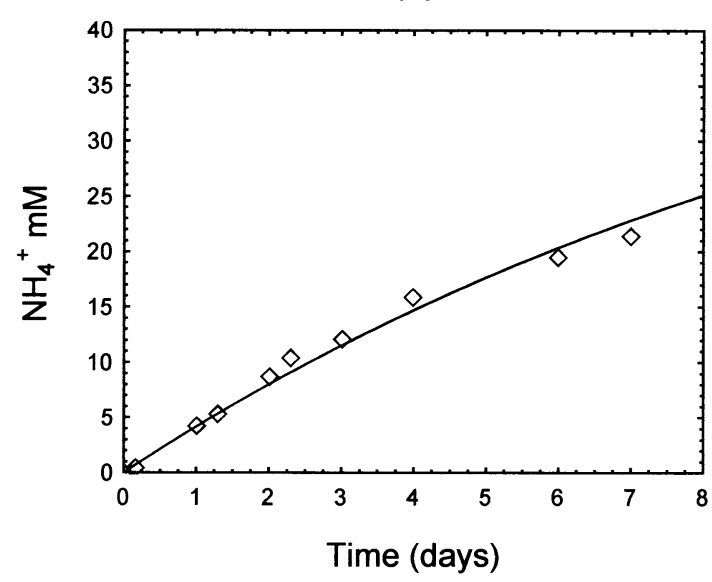

(b)

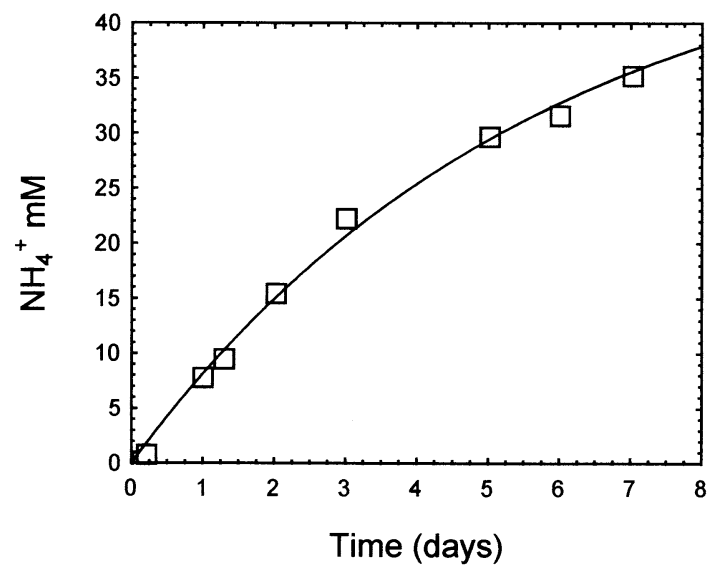

(d)

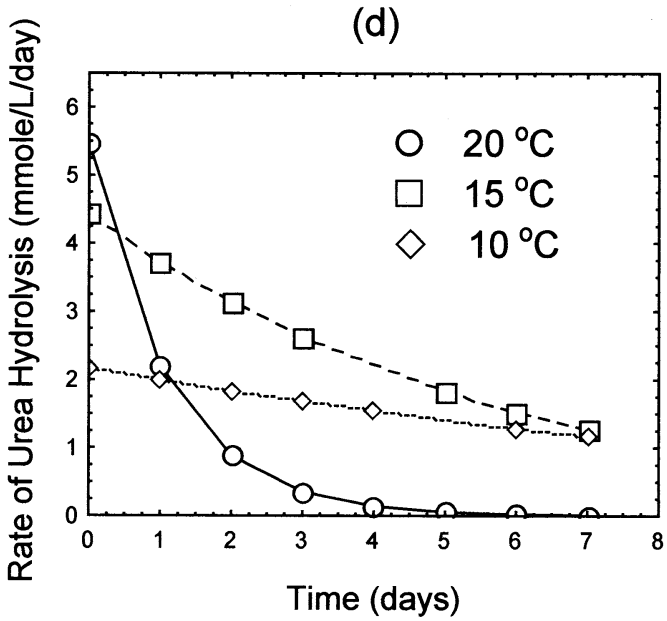

Fig. 1. Dissolved ammonium concentrations arising over time from the hydrolysis of urea by B. pasteurii at (a) $20^{\circ} \mathrm{C}$, (b) $15^{\circ} \mathrm{C}$, and (c) $10^{\circ} \mathrm{C}$. Individual data points are mean values of the triplicate experiments with standard deviations of $< \pm$ $10 \%$ while the curves are corresponding lines of best-fit $\left(\mathrm{r}^{2}\right.$ values of $\left.>0.90\right)$. (d) Calculated urea hydrolysis rates for each of the experimental temperatures.

$\mathrm{HCO}_{3}{ }^{-}=\mathrm{CO}_{3}{ }^{2-}+\mathrm{H}^{+}$buffering with $\mathrm{pK}_{\mathrm{a}}$ values near 9.3 and 10.4 (over the temperature range of the experiments), respectively (Stumm and Morgan, 1996). In the abiotic and $B$. subtilis controls, the $\mathrm{pH}$ drifted slowly upwards from 6.5 at the beginning of the experiments to near 7.2 at the end of the experiments.

Dissolved $\mathrm{Ca}^{2+}$ concentrations started to decrease in an

Table 1. Summary of kinetic parameters for urea hydrolysis $\left(k_{\text {urea }}\right)$, change in saturation state $\left(k_{\mathrm{S}}\right)$, calcite precipitation $\left(k_{p}\right)$, apparent critical saturation $\left(S_{0}\right)$, effective critical saturation $\left(S_{c r i t}\right)$, and delay time for calcite precipitation at different temperatures.

\begin{tabular}{cccccccc}
\hline $\begin{array}{c}\text { Temperature } \\
\left({ }^{\circ} \mathrm{C}\right)\end{array}$ & $\begin{array}{c}k_{\text {urea }} \\
\left(\mathrm{d}^{-1}\right)\end{array}$ & $\begin{array}{c}k_{S} \\
\left(\mathrm{~d}^{-1}\right)\end{array}$ & $\begin{array}{c}k_{p} \\
(\mu \mathrm{mol} / \mathrm{L} / \mathrm{d})\end{array}$ & $S_{0}$ & $S_{\text {crit }}$ & $\begin{array}{c}\text { Delay } \\
\text { time }\end{array}$ \\
\hline 10 & 0.09 & 0.27 & 0.17 & 121 & 72 & 1.89 \\
15 & 0.18 & 0.25 & 0.15 & 96 & 76 & 1.03 \\
20 & 0.91 & 0.26 & 0.16 & 90 & 70 & 0.79 \\
\hline
\end{tabular}

asymptotic fashion after $1 \mathrm{~d}$ at $20^{\circ} \mathrm{C}$ and $15^{\circ} \mathrm{C}$, and $2 \mathrm{~d}$ at $10^{\circ} \mathrm{C}$ (Fig. 2a). The progressive loss of $\mathrm{Ca}^{2+}$ from solution was accompanied by the development of solid phase precipitates that imparted a faint cloudiness to the otherwise transparent bacterial cultures. Analyses of the precipitates at the end of experiments by X-ray diffraction confirmed that the formation of calcite accounted for the observed depletion of dissolved $\mathrm{Ca}^{2+}$ at each of the investigated temperatures.

The most pronounced decrease in dissolved $\mathrm{Ca}^{2+}$ concentrations over time came about at $15^{\circ} \mathrm{C}$ (Fig. 2a). At $20^{\circ} \mathrm{C}$, the depletion of $\mathrm{Ca}^{2+}$ from solution was somewhat less rapid leaving more $\mathrm{Ca}^{2+}$ in solution at the end of the experiments than at $15^{\circ} \mathrm{C}$. On the other hand, an appreciable delay in $\mathrm{Ca}^{2+}$ precipitation was observed at $10^{\circ} \mathrm{C}$; however, once calcite precipitation started $\mathrm{Ca}^{2+}$ concentrations declined to at least the same extent as that which occurred at $15^{\circ} \mathrm{C}$ and $20^{\circ} \mathrm{C}$. While these trajectories of $\mathrm{Ca}^{2+}$ depletion over time do not appear to correlate directly with rates of urea hydrolysis at the different temperatures (Fig. 1d), plots of dissolved $\mathrm{Ca}^{2+}$ con- 
(a)

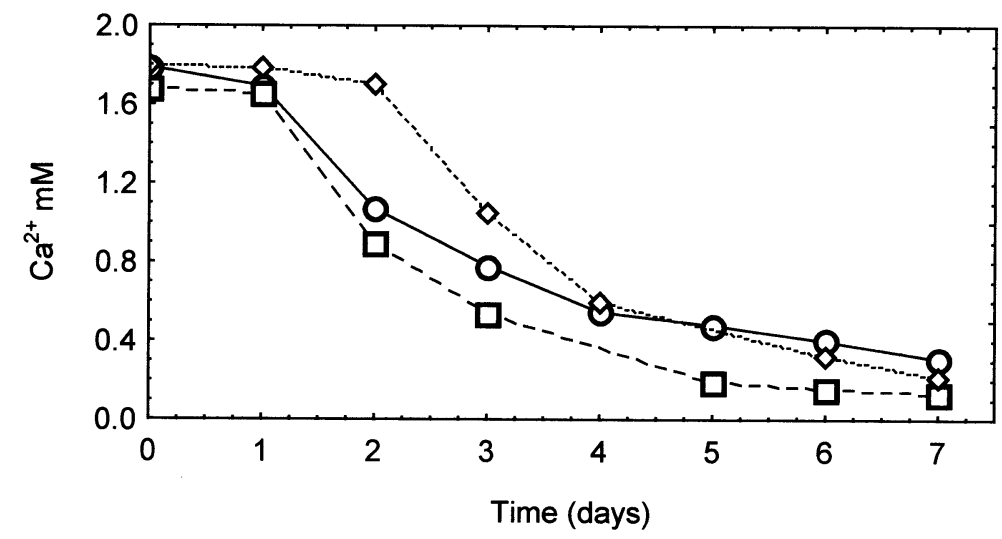

(b)

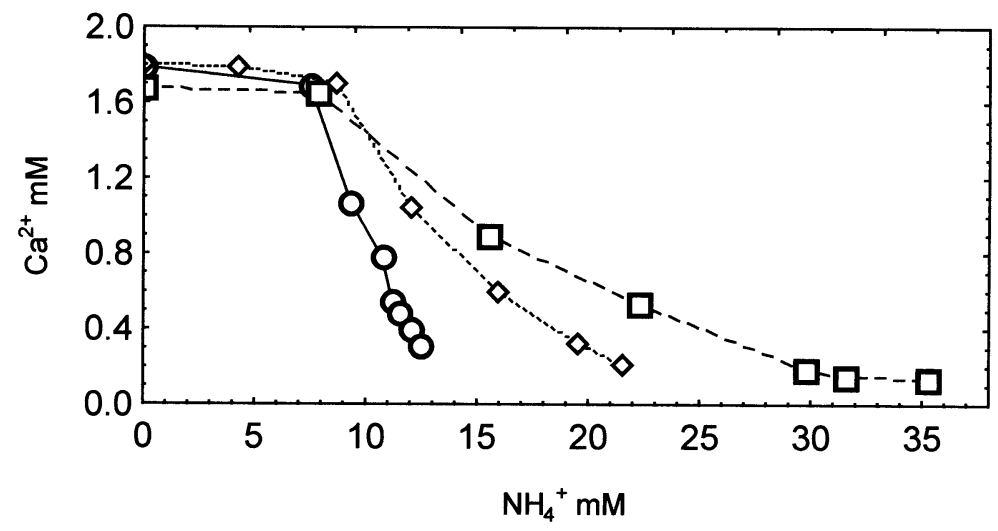

(c)

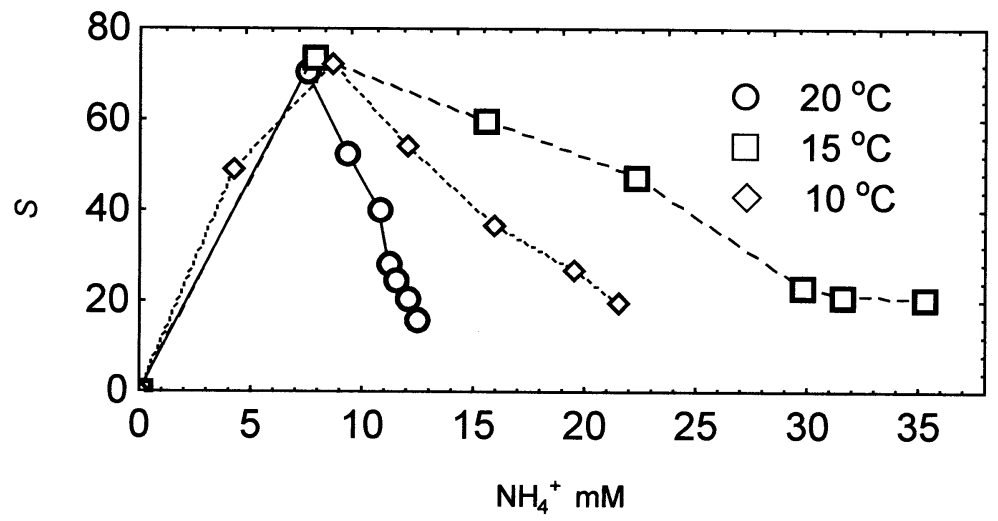

Fig. 2. Dissolved calcium concentrations as a function of (a) time and (b) dissolved ammonium concentrations arising from the hydrolysis of urea by $\mathrm{B}$. pasteurii at $20^{\circ} \mathrm{C}, 15^{\circ} \mathrm{C}$, and $10^{\circ} \mathrm{C}$. Individual data points are mean values of the triplicate experiments with standard deviations of $< \pm 10 \%$ (c) Calculated saturation index $(S)$ values as a function of ammonium concentrations for each of the experimental temperatures.

centrations as a function of produced ammonium (Fig. 2b) show clearly that calcite precipitation was initiated at similar (i.e., approximately $8.0 \mathrm{mM}$ ) concentrations of ammonium. Considering that the initial concentration of dissolved $\mathrm{Ca}^{2+}$ was fixed in the AGW medium, this indicates that calcite precipitation was triggered by approximately the same degree of oversaturation in each of the experiments; i.e., the ratio of the product of dissolved $\mathrm{Ca}^{2+}$ and $\mathrm{CO}_{3}{ }^{2-}$ activities (arising from the hydrolysis of urea by $B$. pasteurii) to the temperature dependent calcite solubility product (Eqn. 6; Stumm and Morgan, 1996). 
(a)

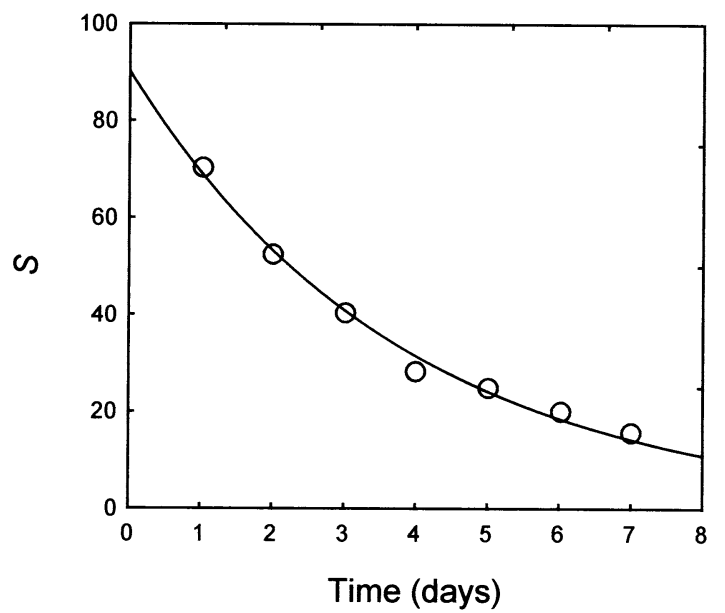

(c)

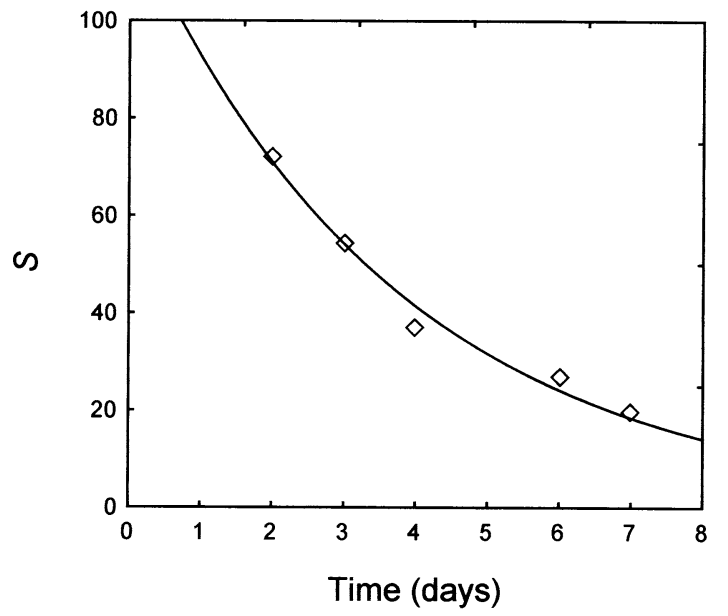

(b)

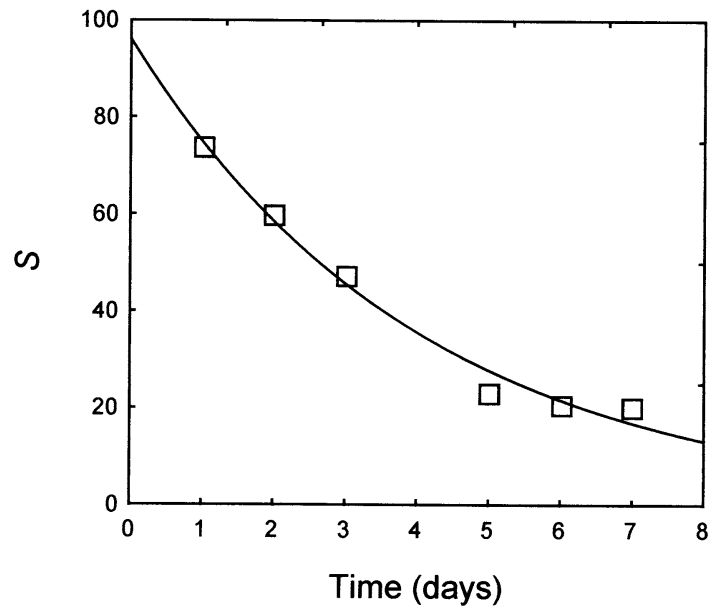

(d)

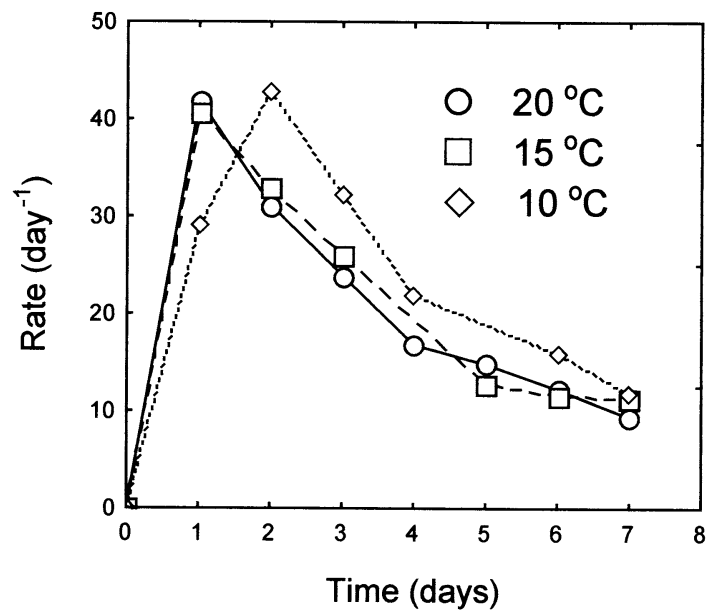

Fig. 3. Regression curves $\left(\mathrm{r}^{2}\right.$ values of $\left.>0.90\right)$ from nonlinear optimization analysis for the observed decrease in saturation index $(S)$ over time after the onset of calcite precipitation at (a) $20^{\circ} \mathrm{C}$, (b) $15^{\circ} \mathrm{C}$, and (c) $10^{\circ} \mathrm{C}$ with $(\mathrm{d})$ the corresponding rates of change in $S$.

The reason for the temporal displacement of $\mathrm{Ca}^{2+}$ precipitation is more precisely evident from plots of the calculated saturation state for the different experiments as a function of ammonium concentrations (Fig. 2c). Initially, saturation states increased rapidly to reach values nearly 80 times greater than the corresponding calcite solubility products (Stumm and Morgan, 1996). At the different temperatures, measured ammonium concentrations around $8.0 \mathrm{mM}$ yielded similar peak saturation state values. The subsequent removal of dissolved $\mathrm{Ca}^{2+}$ and $\mathrm{CO}_{3}{ }^{2-}$ from solution following the onset of calcite precipitation subsequently sustained a decrease in calculated saturation state values that was most evident at $20^{\circ} \mathrm{C}$, and least evident at $15^{\circ} \mathrm{C}$. These different trends can be traced to the greater extent of urea hydrolysis and production of $\mathrm{CO}_{3}{ }^{2-}$ at $15^{\circ} \mathrm{C}$ in comparison to $10^{\circ} \mathrm{C}$ and $20^{\circ} \mathrm{C}$ (Fig. 1).

The anticipated first order dependence for the decrease in saturation state in response to ongoing calcite precipitation over time (Eqn. 11) provided an accurate description (i.e., $r^{2}$ values $>0.90$ ) for experimental data acquired following the onset of
$\mathrm{Ca}^{2+}$ depletion from solution; specifically, $1 \mathrm{~d}$ in the case of $15^{\circ} \mathrm{C}$ and $20^{\circ} \mathrm{C}$, and $2 \mathrm{~d}$ in the case of $10^{\circ} \mathrm{C}$ (Fig. 3). Rate constants (i.e., $k_{S}$ values) determined from the nonlinear optimization were similar at all temperatures (Table 1), as expected given that saturation state values were calculated using temperature compensated calcite solubility products (Stumm and Morgan, 1996). In contrast, estimates for the apparent critical saturation state required for calcite precipitation at $t=0$ (i.e., $S_{O}$ values) increased as temperature decreased (Table 1). This observation is consistent with the increased temporal displacement witnessed in the onset of calcite precipitation at low temperature (Fig. 2); i.e., despite comparable $k_{S}$ values a longer period of time was needed to reach $S_{O}$ at $10^{\circ} \mathrm{C}$ than $15^{\circ} \mathrm{C}$ or $20^{\circ} \mathrm{C}$. In accordance with the estimates for $k_{S}$ and $S_{O}$, the trajectories for calculated rates of change in saturation state at $15^{\circ} \mathrm{C}$ and $20^{\circ} \mathrm{C}$ nearly overlap while a parallel trajectory displaced by $1 \mathrm{~d}$ is followed at $10^{\circ} \mathrm{C}$ (Fig. 3d).

The dissolved $\mathrm{Ca}^{2+}$ concentrations measured at each temperature following the onset of calcite precipitation are plotted 
(a)

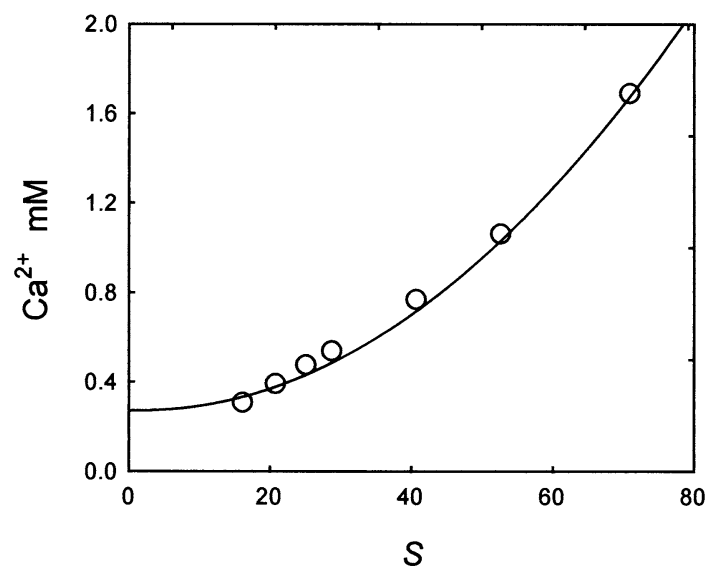

(c)

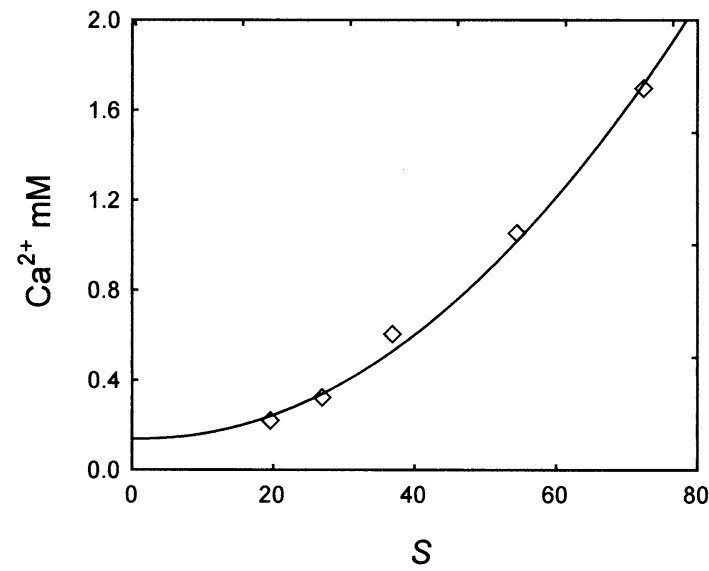

(b)

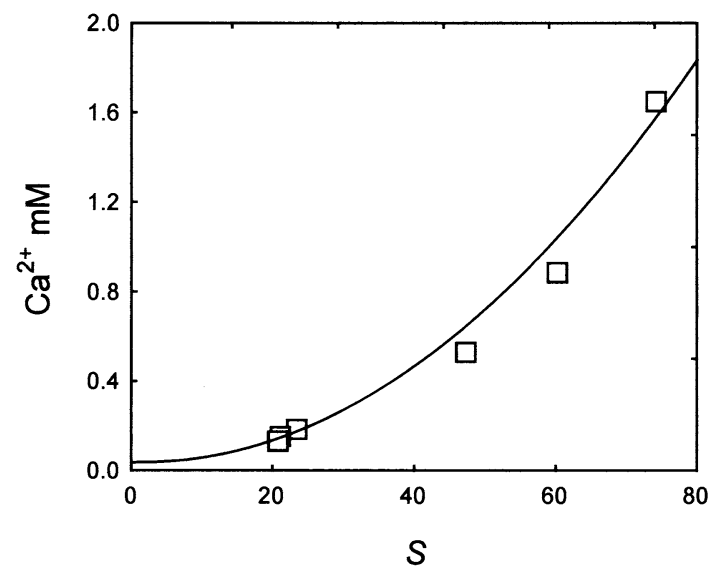

(d)

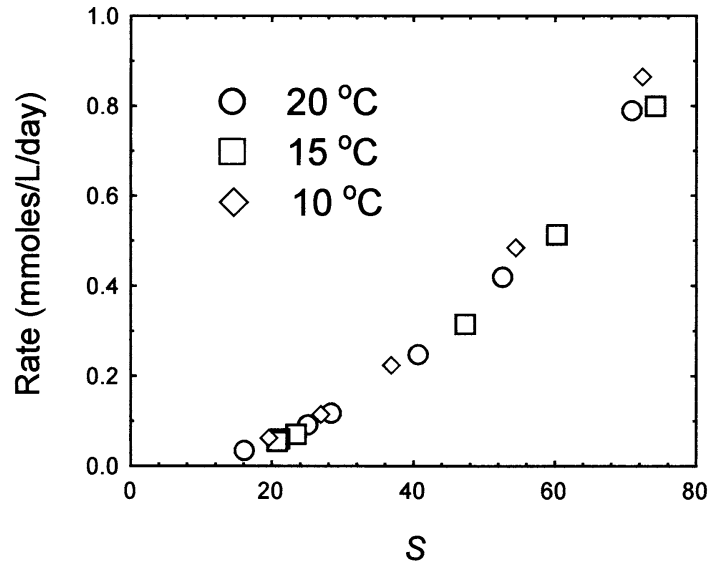

Fig. 4. Dissolved calcium concentrations as a function of saturation index $(S)$ at $20^{\circ} \mathrm{C}, 15^{\circ} \mathrm{C}$, and $10^{\circ} \mathrm{C}$. Individual data points are mean values of the triplicate experiments with standard deviations of $< \pm 10 \%$ while the curves are corresponding lines of best-fit ( $\mathrm{r}^{2}$ values of $>0.90$ ). (d) Calculated calcite precipitation rates as a function of $S$ for each of the experimental temperatures.

in Figure 4 as a function of corresponding saturation state values. Specific rate constants for calcite precipitation $\left(k_{p}\right)$ and effective critical saturation state $\left(S_{\text {critical }}\right)$ derived in accordance with Eqn. 15 from nonlinear optimization analyses (Table 1) yielded individual curves that explain greater than $90 \%$ of the variation in the dissolved $\mathrm{Ca}^{2+}$ concentration data (i.e., $\mathrm{r}^{2}$ values $>0.90$ ). The calcite precipitation rate constants and critical saturation states varied by less than $10 \%$ between the temperatures with mean values of $0.16 \pm 0.01 \mu$ moles $\mathrm{L}^{-1} \mathrm{~d}^{-1}$ and $73 \pm 3$, respectively. This apparent independence of $k_{p}$ and $S_{\text {critical }}$ to temperature is in keeping with the temperature dependency imparted by differences in calcite solubility over the temperature range of the experiments (Stumm and Morgan, 1996). Moreover, the similarity between estimated $S_{\text {critical }}$ values at the different temperatures parallels measurements of dissolved $\mathrm{Ca}^{2+}$ and $\mathrm{NH}_{4}^{+}$concentrations (Fig. 2b) which indicate that calcite precipitation was initiated, regardless of temperature, at equivalent concentrations of $\mathrm{NH}_{4}^{+}$(i.e., ca. 8 $\mathrm{mM}$ ). Substitution of $S_{\text {critical }}$ values into Eqn. 11 permitted further a more precise calculation the delay time for the onset of calcite precipitation in the experiments (Table 1); calculated times of $0.79\left(20^{\circ} \mathrm{C}\right), 1.02\left(15^{\circ} \mathrm{C}\right)$, and $1.89\left(10^{\circ} \mathrm{C}\right) \mathrm{d}$ match closely the delay period for calcite precipitation observed in the dissolved $\mathrm{Ca}^{2+}$ time course data (Fig. 2a).

The highest rates of calcite precipitation (ca. $0.8 \mathrm{mmol} \mathrm{L}^{-1}$ $\mathrm{d}^{-1}$ ), calculated by substitution of experimental $S$ values and corresponding rate constants (Table 1) into Eqn. 12, occurred near $S_{\text {critical }}$ (Fig. 4d). While unique time course trajectories of dissolved $\mathrm{Ca}^{2+}$ concentrations (Fig. 2) and $S$ values (Fig. 3) were observed at the different experimental temperatures, the calcite precipitation rates all follow the same asymptotic profile decreasing progressively with $S$ regardless of temperature (Fig. 4d). This emphasizes the fundamental kinetic dependence of calcite precipitation on $S$, which connects the otherwise dissimilar temporal patterns of calcite precipitation that evolved under the different temperature and biogeochemical regimes of the experiments.

\section{DISCUSSION}

The first-order kinetics of urea hydrolysis by B. pasteurii in the AGW match closely with results from other recent studies 
on ureolytic bacterial activity in soils. Specifically, Nielsen et al. (1998) determined rate constants of $0.01 \mathrm{~d}^{-1}$ to $0.11 \mathrm{~d}^{-1}$ for the hydrolysis of urea in bulk agricultural topsoil. In an examination of deeper vadose zone mineral subsoils, Swensen and Bakken (1998) measured urea hydrolysis rate constants extending from $0.09 \mathrm{~d}^{-1}$ to $1.68 \mathrm{~d}^{-1}$. The rate constants obtained with B. pasteurii fall directly within the range of values from these other investigations, indicating that natural levels of ureolytic bacterial activity were reasonably approximated in the AGW experiments.

The strong dependence of urea hydrolysis on temperature witnessed in the experiments is a common feature of chemical reactions that are advanced through a transient activated complex (Stumm and Morgan, 1996). In urease, the transitional state involves coordination of urea as well as water at the active catalytic site of the enzyme (Jarbi et al., 1995). Formation of such an activated complex tends to impart a greater temperature dependency on the absolute reaction rate than would be encountered if the reaction were mediated solely by collisions arising from molecular diffusion (Stumm and Morgan, 1996). Rates constants determined for urea hydrolysis in soils have thus been found to increase by as much at 18 times over a temperature range of $5^{\circ} \mathrm{C}$ to $20^{\circ} \mathrm{C}$ (Xu et al., 1993; Gillman et al., 1995; Nielsen et al., 1998; Swensen and Bakken, 1998). These observations compare favorably with the 10 -fold rate constant increase evident for urea hydrolysis between $10^{\circ} \mathrm{C}$ and $20^{\circ} \mathrm{C}$ in the $\mathrm{AGW}$ experiments

Investigation of the kinetic behavior of calcite precipitation is conventionally accomplished by either constant addition of reactants to maintain a fixed degree of oversaturation (Spanos and Koutsoukos, 1998; Zuddas and Mucci, 1998; Nilsson and Sternbeck, 1999), or mixing reactant solutions abruptly to predetermine the initial saturation state (Gómez-Morales et al., 1996; Lebron and Suarez, 1996; Zhang and Dawe, 1998). These approaches contrast with the present study in which calcite precipitation was induced in response to the hydrolysis of urea by $B$. pasteurii. The reaction sequence in the presence of the ureolytic bacteria included three distinct stages beginning with the development of an oversaturated solution, followed by nucleation at the point of critical saturation, and then spontaneous crystal growth on the stable nuclei.

The oversaturation of the AGW with respect to calcite was driven by the increase in $\mathrm{pH}$ and total DIC concentrations arising from the hydrolysis of urea by B. pasteurii (Ferris and Stehmeier, 1992; Ferris et al., 1996; Stocks-Fischer et al., 1999; Fujita et al., 2000; Warren et al., 2001); however, the onset of calcite precipitation first required that the point of critical saturation be attained as stable nuclei can only be formed after the nucleation activation (i.e., interfacial) free energy barrier has been surmounted (Stumm and Morgan, 1996). Because of the different urea hydrolysis rates over the temperature range of the experiments, up to $2 \mathrm{~d}$ were needed to reach critical saturation, emphasizing the fundamental importance of bacterial activity for the initiation of calcite precipitation.

Although different lengths of time transpired before nucleation and the onset of calcite precipitation at each temperature, estimates of the corresponding critical saturation points were the same within the variance of the nonlinear optimization analyses. This apparent insensitivity to temperature likely extends from the relatively modest increase in calcite solubility (ca. 7\%) that occurs between $20^{\circ} \mathrm{C}$ and $10^{\circ} \mathrm{C}$ (Stumm and Morgan, 1996). In addition, saturation state values in unseeded precipitation experiments (i.e., from 67-98) that span the critical saturation points realized in this study (Table1) have been shown to trigger spontaneous homogenous three-dimensional nucleation in solution (Gómez-Morales et al., 1996). More recently, Teng et al. (2000) demonstrated that when the saturation state of a solution exceeds approximately 6.3, twodimensional surface nucleation may occur on seed crystals (homogenous) or foreign particles (heterogeneous). Thus, it is reasonable to presume that calcite precipitation in the urea hydrolysis experiments was initiated by a combination of threedimensional nucleation in solution and two-dimensional nucleation on nascent crystals (Spanos and Koutsoukos, 1998), as well as bacterial cell surfaces (Fujita et al., 2000).

The order of nonlinear kinetic models has been used to infer specific mechanisms of crystal growth (e.g., spiral growth) over a broad range of saturation state (Gómez-Morales et al., 1996; Spanos and Koutsoukos, 1998); however, assumption of a general quadratic dependence of precipitation rate on saturation state is appropriate particularly for nonequilibrium (i.e., $S>$ 2.2) crystal growth sustained by a combination of spiral and surface nucleation mechanisms (Teng et al., 2000). Such conditions apply in this study where ongoing hydrolysis of urea by $B$. pasteurii maintained saturation state values in excess of 15 for the duration of the experiments.

Rates of calcite precipitation observed in other studies exceed those measured in the AGW experiments with $B$. pasteurii by one to two orders of magnitude for similar degrees of saturation (Zhang and Dawe, 1998; Zuddas and Mucci, 1998; Nilsson and Sternbeck, 1999); however, precipitation rates are well known to be inhibited to at least the same extent by the presence of water soluble organic ligands, as well as dissolved ions such as $\mathrm{Mg}^{2+}, \mathrm{Sr}^{2+}, \mathrm{Fe}^{2+}, \mathrm{Cu}^{2+}, \mathrm{Zn}^{2+}$, and $\mathrm{NH}_{4}^{+}$ (Sohnel et al., 1990; Gutjahr et al., 1996; Lebron and Suarez, 1996; Zhang and Dawe, 2000). Among these inhibitors, both $\mathrm{Mg}^{2+}\left(0.5 \mathrm{mM}\right.$ ) and $\mathrm{NH}_{4}^{+}$(up to $35 \mathrm{mM}$ ) were present in the AGW. The effect of such inhibitors is usually interpreted to arise from adsorption to and screening of active surface sites that participate in nucleation and crystal growth. Considering these observations, it is highly feasible that $\mathrm{Mg}^{2+}$ in the AGW, and $\mathrm{NH}_{4}{ }^{+}$produced by $\mathrm{B}$. pasteurii from the hydrolysis of urea, contributed to slower rates of calcite precipitation than might otherwise be expected.

The results presented here are for an idealized system that did not include aquifer minerals. As such, it is important to appreciate that the precipitation of calcite by ureolytic bacteria under in situ conditions will differ in two respects. First, the mineral matrix of an aquifer provides abundant sites for twodimensional heterogeneous, as well as homogenous in the case of preexisting calcite, nucleation and crystal growth of calcite. The maximum critical saturation value for calcite precipitation in an aquifer setting will thus be regulated not only by opposing rates of urea hydrolysis and calcite precipitation, which respectively cause $S$ to increase or decline, but also by an increased capacity for two-dimensional nucleation on matrix mineral surfaces; i.e., decrease in the interfacial activation energy barrier for nucleation (Stumm and Morgan, 1996). Second, aquifer minerals comprise a large reservoir of exchangeable divalent cations that are likely to participate in the precipitation process. 
Specifically, urea hydrolysis yields $\mathrm{NH}_{4}^{+}$, which may exchange with $\mathrm{Ca}^{2+}$ and other divalent cations associated with the mineral matrix of an aquifer. In a remediation application where the amount of exchangeable calcium is large relative to the amount of urea added, cation exchange processes will serve to limit the maximum concentration of $\mathrm{NH}_{4}{ }^{+}$in the groundwater and buffer the $\mathrm{Ca}^{2+}$ concentration. Additionally, exchangeable $\mathrm{Ca}^{2+}$ may foster the precipitation of additional calcite to result in near stoichiometric utilization of the hydrolyzed urea (Fujita et al., 2000). The investigation of ureolytic calcite precipitation in the presence of aquifer minerals is a subject of our ongoing numerical, laboratory, and field studies.

\section{CONCLUSIONS}

The rates and temperature dependence of urea hydrolysis measured in the experiments agree well with existing data on the kinetics of ureolytic bacterial activity in soils. This imparts some confidence to the prospect of paralleling the results of the AGW calcite precipitation experiments to potential behavior in groundwater environments. In AGW, bacterial urea hydrolysis is effective at promoting the development of an oversaturated solution, from which calcite precipitation occurs spontaneously when $S_{\text {critical }}$ is finally attained. Once initiated, calcite precipitation rates exhibit a fundamental kinetic dependence on $S$, which is subject to modulation by depletion of $\mathrm{Ca}^{2+}$ from solution and ongoing bacterial urea hydrolysis. Moreover, the comparatively slow rates of calcite precipitation observed in $\mathrm{AGW}$ indicate that inhibitory ions like $\mathrm{Mg}^{2+}$ and $\mathrm{NH}_{4}{ }^{+}$impart additional kinetic constraints, emphasizing the ongoing need for studies under circumstances that simulate natural conditions as closely as possible. This consideration is particularly important for the development of in situ bioremediation scenarios where knowledge of bacterially induced calcite precipitation rates is required to accurately gauge performance.

Acknowledgments-This work was supported by grant DE-FG0799ER15025 from the U.S. Department of Energy, Office of Energy Research, Environmental Management Science Program.

Associate editor: J. Amend

\section{REFERENCES}

Benini S., Gessa C., and Ciurli S. (1996) Bacillus pasteurii urease: A heteropolymeric enzyme with a binuclear nickel active site. Soil Biol. Biochem. 28, 819-821.

Clancy A. and Burne R. A. (1997) Construction and characterization of a recombinant ureolytic Streptococcus mutans and its use to demonstrate the relationship of urease activity to $\mathrm{pH}$ modulating capacity. FEMS Microbiol. Lett. 151, 205-211.

Ferris F. G. and Stehmeier L. G. (1992) Bacteriogenic mineral plugging. Patent 5,143,155. Washington, D.C.: U.S. Patent Office.

Ferris F. G., Wiese R. G., and Fyfe W. S. (1994) Precipitation of carbonate minerals by microorganisms: Implications for silicate weathering and the global carbon dioxide budget. Geomicrobiol. J. 12, $1-13$.

Ferris F. G., Fratton C. M., Gerits J. P., Schultze-Lam S., and Sherwood Lollar B. (1995) Microbial precipitation of a strontium calcite phase at a groundwater discharge zone near Rock Creek, Br. Columbia, Canada. Geomicrobiol. J. 13, 57-67.

Ferris F. G., Stehmeier L. G., Kantzas A., and Mourits F. M. (1996) Bacteriogenic mineral plugging. J. Can. Petrol. Technol. 35, 56-61.

Fortin D., Ferris F. G., and Beveridge T. J. (1997) Surface-mediated mineral development by bacteria. Rev. Mineral. 35, 161-180.
Fujita Y., Ferris F. G., Lawson R. D., Colwell F. S., and Smith R. W. (2000) Calcium carbonate precipitation by ureolytic subsurface bacteria. Geomicrobiol. J. 17, 305-318.

Gillman E., Morgan M. A., and Sherwood M. (1995) Urease activity in Irish soils at $6^{\circ}$ C. Biol. Environ. Proc. R. Irish Acad. 95B, 19-26.

Gómez-Morales J., Torrent-Burgués J., and Rodríguez-Clemente R. (1996) Nucleation of calcium carbonate at different initial $\mathrm{pH}$ conditions. J. Crystal Growth 169, 331-338.

Gutjahr A., Dabringhaus H., and Lacmann R. (1996) Studies of the growth and dissolution kinetics of the $\mathrm{CaCO} 3$ polymorphs calcite and aragonite II. The influence of divalent cation additives on the growth and dissolution rates. J. Crystal Growth 158, 310-315.

House W. (1981) Kinetics of crystallization of calcite from calcium bicarbonate solutions. J. Chem. Soc. Faraday Trans. 77, 341-359.

Jahns T. (1996) Ammonium/urea-dependent generation of a proton electrochemical potential and synthesis of ATP in Bacillus pasteurii. J. Bacteriol. 178, 403-409.

Jarbi E., Carr M. B., Hausinger R. P., and Karplus P. A. (1995) The crystal structure of urease from Klebsiella aerogenes. Science $\mathbf{2 6 8}$, 998-1004.

Knobel L. L., Bartholomay R. C., Cecil L. D., Tucker B. J. and Wegner S. J. (1992) Chemical constituents in the dissolved and suspended fractions of ground water from selected sites, Idaho National Engineering Laboratory and vicinity, Idaho, 1989. Open-File Report 92-51. Idaho Falls, U.S. Geological Survey.

Lebron I. and Suarez D. L. (1996) Calcite nucleation and precipitation kinetics as affected by dissolved organic matter at $25^{\circ} \mathrm{C}$ and $\mathrm{pH}>$ 7.5. Geochim. Cosmochim. Acta 60, 2765-2776.

Nielsen T. H., Bonde T. A., and Sørensen J. (1998) Significance of microbial urea turnover in $\mathrm{N}$ cycling of three Danish agricultural soils. FEMS Microbiol. Ecol. 25, 147-157.

Nilsson Ö. and Sternbeck J. (1999) A mechanistic model for calcite crystal growth using surface speciation. Geochim. Cosmochim. Acta 63, 217-225.

Pentecost A. and Spiro B. (1990) Stable carbon and oxygen isotope composition of calcites associated with modern freshwater cyanobacteria and algae. Geomicrobiol. J. 8, 17-26.

Reddy M. M. and Nancollas G. H. (1971) The crystallization of calcium carbonate I. Isotopic exchange and kinetics. J. Colloid Interface Sci. 36, 166-172.

Riley R. G. and Zachara J. M. (1992) Chemical Contaminants on DOE Lands and Selection of Contaminant Mixtures for Subsurface Science Research. DOE/ER-0547T, U.S. Department of Energy, Office of Energy Research, Washington, D.C.

Schultze-Lam S. and Beveridge T. J. (1994) Nucleation of celestite and strontianite on a cyanobacterial S-layer. Appl. Environ. Microbiol. 60, 447-453.

Shiraki R. and Brantley S. L. (1995) Kinetics of near-equilibrium calcite precipitation at $100^{\circ} \mathrm{C}$ : An evaluation of elementary reactionbased and affinity based rate laws. Geochim. Cosmochim. Acta 59, 1457-1471.

Smith D. G., Russell W. C., Ingledew W. J., and Thirkell D. (1993) Hydrolysis of urea by Ureaplasma urealyticum generates a transmembrane potential with resultant ATP synthesis. J. Bacteriol. 175, 3253-3258.

Sohnel O., Handlirova M., and Macenauer J. (1990) Kinetics of growth of calcite crystals in presence of ammonium ions. Crystal Res. Technol. 25, 1367-1373.

Spanos N. and Koutsoukos P. G. (1998) Kinetics of precipitation of calcium carbonate in alkaline $\mathrm{pH}$ at constant supersaturation. Spontaneous and seeded growth. J. Phys. Chem. B 102, 6679-6684.

Stocks-Fisher S., Galinat J. K., and Bang S. S. (1999) Microbiological precipitation of CaCO3. Soil Biol. Biochem. 31, 1563-1571.

Stumm W. and Morgan J. J. (1996) Aquatic Chemistry 3rd ed. Wiley. Swensen B. and Bakken L. R. (1998) Nitrification potential and urease activity in a mineral subsoil. Soil Biol. Biochem. 30, 1333-1341.

Teng H. H., Dove P. M., and De Yoreo J. J. (2000) Kinetics of calcite growth: Surface processes and relationships to macroscopic rate laws. Geochim. Cosmochim. Acta 64, 2255-2266.

Tesoriero A. J. and Pankow J. F. (1996) Solid Solution Partitioning of $\mathrm{Sr}^{2+}, \mathrm{Ba}^{2+}$, and $\mathrm{Cd}^{2+}$ to Calcite. Geochim. Cosmochim. Acta $6 \mathbf{0}$, 1053-1063. 
Thompson J. G. and Ferris F. G. (1990) Cyanobacterial Precipitation of Gypsum, Calcite, and Magnesite from Natural Alkaline Lake Water. Geology 18, 995-998.

Tobin K. J., Colwell F. S., Onstott T. C., and Smith R. (2000) Recent calcite spar in an aquifer waste plume: A possible example of contamination driven calcite precipitation. Chem. Geol. 169, 449460.

Warren L. A., Maurice P. A., Parmar N., and Ferris F. G. (2001) Microbially mediated calcium carbonate precipitation: Implications for interpreting calcite precipitation and for solid phase capture of inorganic contaminants. Geomicrobiol. J. 18, 93-115.

Wood W. W. and Low L. H. (1986) Aqueous geochemistry and diagenesis in the Eastern Snake River Plain aquifer system, Idaho. Geol. Soc. Am. Bull. 97, 1456-1466.
Xu J. G., Heeraman D. A., and Wang Y. (1993) Fertilizer and temperature effects on urea hydrolysis in undisturbed soil. Biol. Fertil. Soils 16, 63-65.

Zachara J. M., Cowan C. E., and Resch C. T. (1991) Sorption of divalent metals on calcite. Geochim. Cosmochim. Acta 55, 15491562.

Zhang Y. and Dawe R. (1998) The kinetics of calcite precipitation from a high salinity water. Appl. Geochem. 13, 177-184.

Zhang Y. and Dawe R. (2000) Influence of $\mathrm{Mg}^{2+}$ on the kinetics of calcite precipitation and calcite crystal morphology. Chem. Geol. 163, 129-138.

Zuddas P. and Mucci A. (1998) Kinetics of calcite precipitation from seawater: II. The influence of the ionic strength. Geochim. Cosmochim. Acta 62, 757-766. 


\section{Appendix C:}

Strontium incorporation into calcite generated by bacterial ureolysis.

By Y. Fujita, G.D. Redden, J.A. Ingram, M.M. Cortez, and R.W. Smith.

In Geochimica et Cosmochimica Acta. 68:3261-3270 (2004). 
doi:10.1016/j.gca.2003.12.018

\title{
Strontium incorporation into calcite generated by bacterial ureolysis
}

\author{
Yoshiko Fujtta, ${ }^{1} *$ George D. Redden, ${ }^{1}{ }^{\text {Jani C. Ingram, }}{ }^{2}$ Marnie M. Cortez, ${ }^{1}$ F. Grant Ferris,${ }^{3}$ and Robert W. Smith ${ }^{4}$ \\ ${ }^{1}$ Idaho National Engineering and Environmental Laboratory, P.O. Box 1625, Idaho Falls, ID 83415, USA \\ ${ }^{2}$ Northern Arizona University, Flagstaff, AZ 86011, USA \\ ${ }^{3}$ University of Toronto, Toronto, Ontario, Canada M5S 3B1 \\ ${ }^{4}$ University of Idaho-Idaho Falls, Idaho Falls, ID 83402, USA
}

(Received July 1, 2003; accepted in revised form December 2, 2003)

\begin{abstract}
Strontium incorporation into calcite generated by bacterial ureolysis was investigated as part of an assessment of a proposed remediation approach for ${ }^{90} \mathrm{Sr}$ contamination in groundwater. Urea hydrolysis produces ammonium and carbonate and elevates $\mathrm{pH}$, resulting in the promotion of calcium carbonate precipitation. Urea hydrolysis by the bacterium Bacillus pasteurii in a medium designed to mimic the chemistry of the Snake River Plain Aquifer in Idaho resulted in a $\mathrm{pH}$ rise from 7.5 to 9.1. Measured average distribution coefficients $\left(\mathrm{D}_{\mathrm{EX}}\right)$ for $\mathrm{Sr}$ in the calcite produced by ureolysis $(0.5)$ were up to an order of magnitude higher than values reported in the literature for natural and synthetic calcites $(0.02-0.4)$. They were also higher than values for calcite produced abiotically by ammonium carbonate addition (0.3). The precipitation of calcite in these experiments was verified by X-ray diffraction. Time-of-flight secondary ion mass spectrometry (ToF SIMS) depth profiling (up to $350 \mathrm{~nm}$ ) suggested that the Sr was not merely sorbed on the surface, but was present at depth within the particles. X-ray absorption near edge spectra showed that $\mathrm{Sr}$ was present in the calcite samples as a solid solution. The extent of $\mathrm{Sr}$ incorporation appeared to be driven primarily by the overall rate of calcite precipitation, where faster precipitation was associated with greater $\mathrm{Sr}$ uptake into the solid. The presence of bacterial surfaces as potential nucleation sites in the ammonium carbonate precipitation treatment did not enhance overall precipitation or the $\mathrm{Sr}$ distribution coefficient. Because bacterial ureolysis can generate high rates of calcite precipitation, the application of this approach is promising for remediation of ${ }^{90} \mathrm{Sr}$ contamination in environments where calcite is stable over the long term. Copyright (C) 2004 Elsevier Ltd
\end{abstract}

\section{INTRODUCTION}

The partitioning of trace elements into calcite has long been of interest for inferring the diagenetic history of authigenic carbonates. More recently, partitioning of metals in carbonates has also generated interest as a means for immobilizing toxic radionuclide or metal contaminants (e.g., ${ }^{90} \mathrm{Sr},{ }^{60} \mathrm{Co}, \mathrm{Cd}$ ) in the subsurface (e.g., Davis et al., 1987; Tesoriero and Pankow, 1996; Curti, 1999). Partitioning may occur passively, resulting in remediation analogous to "natural attenuation" as described for several organic pollutants (Wiedemeier et al., 1999), but enhancement of the process could also occur as part of an active remediation strategy. One intriguing approach is to exploit microbial activities to accelerate coprecipitation of trace metals in calcite. Carbonate mineral precipitation by microorganisms has been known for many years (Ehrlich, 1996; Castanier et al., 1999), and several different mechanisms for extracellular carbonate precipitation have been identified. Ehrlich (1996) lists five conditions that can result in solid carbonate production when appropriate cations are available, including: (1) aerobic and anaerobic oxidation of organic compounds in a well buffered neutral or alkaline environment; (2) aerobic or anaerobic oxidation of organic nitrogen compounds to produce ammonia and $\mathrm{CO}_{2}$ in unbuffered environments; (3) reduction of gypsum to $\mathrm{CaS}$ by sulfate-reducing bacteria using organic electron donors; (4) the hydrolysis of urea; and (5) removal of $\mathrm{CO}_{2}$ from bicarbonate-containing solutions.

Among the aforementioned mechanisms for microbial car-

* Author to whom correspondence should be addressed (fujiy@inel.gov). bonate precipitation, the hydrolysis of urea is an especially promising approach for inducing calcite precipitation for the purpose of immobilizing contaminants in the subsurface. Urea hydrolysis results in the production of ammonium and bicarbonate, and an increase in $\mathrm{pH}$ (Eqn. 1). The increased alkalinity favors carbonate mineral precipitation. Eqn. 2 shows the calcite precipitation reaction at circum-neutral $\mathrm{pH}$.

$$
\begin{gathered}
\mathrm{H}_{2} \mathrm{NCONH}_{2}+2 \mathrm{H}_{2} \mathrm{O}+\mathrm{H}+\rightarrow 2 \mathrm{NH}_{4}{ }^{+}+\mathrm{HCO}_{3}{ }^{-} \\
\mathrm{Ca}^{2+}+2 \mathrm{HCO}_{3}{ }^{-} \rightarrow \mathrm{CaCO}_{3}(\mathrm{~s})+\mathrm{CO}_{2}+\mathrm{H}_{2} \mathrm{O}
\end{gathered}
$$

In systems where $\mathrm{CO}_{2}$ removal occurs (e.g., in a phreatic aquifer, or a vadose zone), precipitation is further enhanced. Urea hydrolyzing bacteria are widespread in the environment (Mobley and Hausinger, 1989; Fujita et al., 2000), and therefore an in situ remediation scheme based on urea hydrolysis is not likely to require the introduction of foreign microorganisms. The subsurface hydrolysis of urea offers the additional benefit of producing ammonium which can exchange for sorbed strontium and other metals (as well as calcium) on aquifer solids, resulting in their enhanced susceptibility to subsequent capture via a more permanent immobilization mechanism, in this case coprecipitation in calcite.

Ureolytically driven calcite precipitation has been previously investigated for manipulation of fluid flow in porous media (Ferris and Stehmeier, 1992; Ferris et al., 1996), for crack remediation in concrete, granite or other media (Stocks-Fischer et al., 1999; Ramachandran et al., 2001), and for calcium removal from wastewater (Hammes et al., 2003), but thus far there has been only one report on its application for contami- 
nant remediation (Warren et al., 2001). Warren et al. (2001) observed that strontium uptake into calcite generated by bacterial ureolysis was significant and rapid, uranyl partitioning occurred to a lesser extent and was reversible, and copper uptake into calcite was also limited, apparently due to the toxicity of the $\mathrm{Cu}$ to the microorganisms (Bacillus pasteurii). They concluded that calcite precipitation induced by urea hydrolyzing microorganisms was a promising approach for ${ }^{90} \mathrm{Sr}$ remediation in aquifers rich in calcium carbonate.

The primary aim of the research presented here was to extend the findings of Warren et al. (2001), by examining more closely the effect of bacterial ureolysis on the uptake of strontium during calcite precipitation. Specifically, we wanted to quantify the distribution coefficient of $\mathrm{Sr}$ in calcite generated by bacterial ureolysis, and compare it to values reported for $\mathrm{Sr}$ in natural calcites or calcites generated synthetically by methods other than ureolysis. We hypothesized that the distribution coefficients for $\mathrm{Sr}$ in ureolytically generated calcites would be higher than in typical natural calcites, since rapid calcite precipitation can be induced by ureolysis (Stocks-Fischer et al., 1999; Fujita et al., 2000; Warren et al., 2001). Previous researchers have linked greater $\mathrm{Sr}$ incorporation to faster calcite precipitation (see following section), and we wanted to know whether this correlation was also applicable to ureolytically generated calcite. We also sought to characterize the mode of $\mathrm{Sr}$ incorporation into ureolytically generated calcite, to aid in the prediction of the long-term behavior of $\mathrm{Sr}$ immobilized by this mechanism.

Another motivation for this work was the need to evaluate the potential for this remediation approach in a geochemical system more closely resembling natural groundwater, unlike the artificial microbiological media used in previous studies (Fujita et al., 2000; Warren et al., 2001). In this case we were specifically interested in conditions relevant to the Snake River Plain Aquifer (SRPA), which underlies the Idaho National Engineering and Environmental Laboratory (INEEL). ${ }^{90} \mathrm{Sr}$ is a significant aquifer and vadose zone contaminant at the INEEL, as well as at a number of DOE facilities across the U.S. (Riley and Zachara, 1992). The SRPA is already supersaturated with respect to calcite (Wood and Low, 1986), and for this reason represents an ideal location for testing the application of accelerated calcite precipitation for sequestration of ${ }^{90} \mathrm{Sr}$. Following a return to premanipulation conditions, carbonate precipitates formed in the SRPA during an engineered remediation scheme should be stable. We have previously reported the ability of groundwater microorganisms isolated from the SRPA to link urea hydrolysis and calcite precipitation in the laboratory (Fujita et al., 2000). For the experiments described here, we used Bacillus pasteurii, a well-characterized bacterium known for high urease activity and previously shown to induce calcite precipitation in urea-amended medium (Stocks-Fischer et al., 1999; Fujita et al., 2000; Warren et al., 2001). We also assessed the effect of adding bacterial cells when precipitation was driven by abiotic ammonium carbonate addition, in the absence of ureolysis. Specifically, we were interested in whether cell surfaces could themselves exert a physical control on the coprecipitation process, by aiding nucleation. We hypothesized that the addition of nucleation sites could lead to an increase in the overall nucleation rate, leading to the formation of many small crystals rather than the growth of larger crystals, as well as to more rapid precipitation. As discussed below, both factors have been implicated in increasing Sr partitioning into calcite. All experiments were conducted in synthetic groundwater designed to mimic the chemistry of the SRPA. The carbonate precipitates were analyzed for metal composition, morphology, elemental depth, and $\mathrm{Sr}$ bonding characteristics.

\section{BACKGROUND: Sr PARTITIONING IN CALCITE}

For a solid solution of $\mathrm{Sr}$ in calcite, at equilibrium the amount of $\mathrm{Sr}$ in the solid phase is related to the composition of the aqueous phase by

$$
\begin{gathered}
\mathrm{CaCO}_{3}+\mathrm{Sr}^{2+} \Leftrightarrow \mathrm{Ca}^{2+}+\mathrm{SrCO}_{3} \\
\mathrm{~K}_{\mathrm{EX}}=\frac{\mathrm{K}_{\mathrm{CaCO}_{3}}}{\mathrm{~K}_{\mathrm{SrCO}_{3}}}=\frac{\lambda_{\mathrm{SrCO}_{3}} \cdot \chi_{\mathrm{SrCO}_{3}} \cdot \gamma_{\mathrm{Ca}^{2+}} \cdot \mathrm{m}_{\mathrm{Ca}^{2+}}}{\lambda_{\mathrm{CaCO}_{3}} \cdot \chi_{\mathrm{CaCO}_{3}} \cdot \gamma_{\mathrm{Sr}^{2+}} \cdot \mathrm{m}_{\mathrm{Sr}^{2+}}} \\
\frac{\mathrm{K}_{\mathrm{CaCO}_{3}} \cdot \lambda_{\mathrm{CaCO}_{3}} \cdot \gamma_{\mathrm{Sr}^{2+}}}{\mathrm{K}_{\mathrm{SrCO}_{3}} \cdot \lambda_{\mathrm{SrCO}_{3}} \cdot \gamma_{\mathrm{Ca}^{2+}}}=\frac{\chi_{\mathrm{SrCO}_{3}} \cdot \mathrm{m}_{\mathrm{Ca}^{2+}}}{\chi_{\mathrm{CaCO}_{3}} \cdot \mathrm{m}_{\mathrm{Sr}^{2+}}}
\end{gathered}
$$

where $\mathrm{K}_{\mathrm{EX}}$ is the equilibrium constant for the exchange reaction, $\mathrm{K}_{\mathrm{CaCO} 3}$ and $\mathrm{K}_{\mathrm{SrCO} 3}$ are solubility products for pure calcite and $\mathrm{SrCO}_{3}$ (with the calcite structure), respectively, $\gamma_{\mathrm{i}}$ and $\mathrm{m}_{\mathrm{i}}$ are the activity coefficient and molality of the subscripted aqueous species, and $\chi_{\mathrm{i}}$ and $\lambda_{\mathrm{i}}$ are the mole fraction and solid phase activity coefficients for the subscripted solid phases. In this case, $\chi_{\mathrm{SrCO} 3}=\left(1-\chi_{\mathrm{CaCO} 3}\right)$. In principle the equilibrium partitioning of $\mathrm{Sr}$ in calcite could be calculated from thermodynamic considerations. However, because of difficulties associated with determining solid phase activity coefficients and the solubility product of $\mathrm{SrCO}_{3}$ in the calcite structure, an empirical distribution coefficient is generally used to describe $\mathrm{Sr}$ partitioning in calcite. The empirical distribution coefficient is given by an expression similar to Eqn. 5 in which the left-hand side is replaced with a constant that is dependent upon the physicochemical condition of the system:

$$
\mathrm{D}_{\mathrm{EX}}=\frac{\chi_{\mathrm{SrCO}_{3}} \cdot \mathrm{m}_{\mathrm{Ca}^{2+}}}{\chi_{\mathrm{CaCO}_{3}} \cdot \mathrm{m}_{\mathrm{Sr}^{2+}}}
$$

In batch system experiments such as those described here, the logarithmic law of Doerner and Hoskins (1925) is used to derive values of $\mathrm{D}_{\mathrm{EX}}$ solely from changes in the compositions of the aqueous phase

$$
\ln _{\text {init }} \frac{m_{\mathrm{Sr}^{2+}}}{\mathrm{m}_{\mathrm{Sr}^{2+}}}=\mathrm{D}_{\mathrm{EX}} \ln _{\text {init }_{\mathrm{Ca}^{2+}}}
$$

where ${ }^{\text {init }} \mathrm{m}_{\mathrm{i}}$ is the initial aqueous concentration of the subscripted species. Inspection of Eqn. 7 indicates that an average value of $\mathrm{D}_{\mathrm{EX}}$ can be derived from measurements of the initial and final solution compositions. The slope of $\ln \left(\mathrm{m}_{\mathrm{Sr}}{ }^{2+} \mu^{\text {init }} \mathrm{m}_{\mathrm{Sr}}{ }^{2+}\right)$ plotted vs. $\ln \left(\mathrm{m}_{\mathrm{Ca}}{ }^{2+} \mu^{\text {init }} \mathrm{m}_{\mathrm{Ca}}{ }^{2+}\right)$ yields the value for $\mathrm{D}_{\mathrm{EX}}$.

However, previous experimental work has shown that the $\mathrm{D}_{\mathrm{EX}}$ for $\mathrm{Sr}$ in calcite is not necessarily a constant, but is a function of precipitation rate (Lorens, 1981; Pingitore and Eastman, 1986; Tesoriero and Pankow, 1996), with higher values of $\mathrm{D}_{\mathrm{EX}}$ associated with higher precipitation rates. Lorens (1981) offered an explanation related to coordination of the $\mathrm{Sr}$ on the calcite surface. When $\mathrm{Sr}$ sorbs to the growing calcite surface it is initially only partially coordinated to carbonate 
oxygens, but if precipitation is slow there is time for equilibration such that only fully coordinated $\mathrm{Sr}$ is maintained, and the resulting distribution coefficient is close to the equilibrium value. At faster precipitation rates there is less time for equilibration, and so more $\mathrm{Sr}$ is trapped in the calcite lattice in partial coordination (Lorens, 1981). Pingitore and Eastman (1986) proposed another possible mechanism for the rate effect, based on the assumption that $\mathrm{Sr}$ can occupy both the normal lattice position of $\mathrm{Ca}$ and nonlattice defect sites in calcite. At higher degrees of supersaturation (e.g., faster precipitation rate), the number of crystal defects increases because surface nucleation rather than step flow is the dominant growth mechanism (Teng et al., 2000), and therefore there are more potential locations for $\mathrm{Sr}$ incorporation. Rimstidt et al. (1998) point out another potential contributing factor for higher $\mathrm{Sr}$ incorporation at faster precipitation rates. As calcite precipitation proceeds, the ratio of $\mathrm{Sr}: \mathrm{Ca}$ in solution increases. At high precipitation rates, a concentration gradient develops, such that the solution boundary layer nearest the growing calcite surface has a higher $\mathrm{Sr}: \mathrm{Ca}$ ratio than the bulk solution (Rimstidt et al., 1998). The higher concentration of Sr near the surface can then be trapped in the calcite, through either of the two mechanisms described above.

The observations that fast precipitation can be associated with increased $\mathrm{Sr}$ partitioning suggest a possible explanation for reports that microbiologically produced calcites have high (as compared to predictions based on equilibrium considerations) distribution coefficients for $\mathrm{Sr}$ and other trace metals (Schultzelam and Beveridge, 1994; Ferris et al., 1995). Microbial activities can alter the saturation indices for carbonate minerals, and cell surfaces can serve as nucleation sites (Ferris et al., 1987; Mcgenity and Sellwood, 1999). Both of these factors can serve to increase the rate of precipitation, and thereby increase the partitioning of $\mathrm{Sr}$ into calcite. Another possible factor that has been suggested is that the fine grained minerals typically formed during biomineralization (Buczynski and Chafetz, 1991) tolerate lattice substitutions more readily than larger grained minerals (Ferris et al., 1995). An objective of this research was to consider these possibilities with respect to ureolytically driven calcite precipitation.

\section{MATERIALS AND METHODS}

\subsection{Materials}

All chemicals, unless noted otherwise, were ACS reagent grade, purchased from Sigma (St. Louis, MO), Aldrich (Milwaukee, WI), Fisher (Pittsburgh, PA), J. T. Baker (Phillipsburg, NJ) or Fluka (Buchs, Switzerland).

\subsection{Synthetic Groundwater}

The composition of the synthetic water developed for use in the laboratory experiments was based on typical water chemistry data for the Snake River Plain Aquifer in the vicinity of the INEEL (Knobel et al., 1992). The synthetic groundwater contained $\mathrm{KNO}_{3}(0.040 \mathrm{mM})$, $\mathrm{MgSO}_{4}(0.45 \mathrm{mM}), \mathrm{CaCl}_{2}(1.8 \mathrm{mM}), \mathrm{NaNO}_{3}(0.040 \mathrm{mM}), \mathrm{NaHCO}_{3}$ $(1.1 \mathrm{mM})$, and $\mathrm{KHCO}_{3}(0.062 \mathrm{mM})$. Strontium was added at $0.1 \mathrm{mM}$, as $\mathrm{SrNO}_{3}$. The salts were dissolved in nanopure water $(\geq 16+$ megohms-cm; Barnstead, Dubuque, IA). For the experiments including urea, $33 \mathrm{mmol}$ of reagent grade urea was added per liter of synthetic groundwater, and the medium was filter-sterilized $(0.2 \mu \mathrm{m})$. The synthetic groundwater was prepared at $2 \times$ strength before the start of the experiments.

\subsection{Coprecipitation Experiments}

Bacillus pasteurii (ATCC 11859) was grown overnight in Brain Heart Infusion (BHI) broth (BD/Difco, Baltimore, MD) amended with $2 \%$ urea. Bacillus subtilis strain 186 (ATCC 23857) was grown overnight in tryptic soy broth (BD/Difco). Cells were harvested by centrifugation $(13,000 \times g)$, washed three times in sterile synthetic groundwater, and resuspended in sterile nanopure water at a fixed optical density $\left(\mathrm{OD}_{600}=0.2\right)$ immediately before use in the experiments. The resulting optical density $\left(\mathrm{OD}_{600}=0.1\right)$ in the reconstituted synthetic groundwater corresponded to an approximate cell density of $3.4 \pm 1.2$ $\times 10^{7}$ cells $/ \mathrm{mL}$ (Acridine Orange direct count; Kepner and Pratt, 1994). At the beginning of the experiments, equal volumes $(200 \mathrm{~mL})$ of cell suspension or sterile nanopure water (for the ammonium carbonate experiment) and sterile $2 \times$ synthetic groundwater ( $\mathrm{pH}$ adjusted to 7.5 ) were mixed together, and continuous $\mathrm{pH}$ monitoring was initiated. The reaction vessel was maintained at $20{ }^{\circ} \mathrm{C}$ with a water bath and loosely covered, but still open to the laboratory atmosphere. The solution was continuously stirred over the course of the 8-h experiment. For the abiotic precipitation experiments, an ammonium carbonate solution was used to induce calcite precipitation. Commercial ammonium carbonate is available only as a variable mixture of ammonium carbonate and ammonium bicarbonate. Alkalinity and $\mathrm{pH}$ measurements suggested that our ammonium carbonate (Fisher ACS) was approximately 98.5\% ammonium bicarbonate and $1.5 \%$ ammonium carbonate. A stock solution of the ammonium (bi)carbonate was added to the medium over the course of the first $15 \mathrm{~min}$ of the abiotic precipitation experiments to yield an estimated addition of approximately 34.6 $\mathrm{mEq} / \mathrm{L}$ ammonium. At predefined intervals, sample aliquots were removed from the experimental flasks for $\mathrm{Ca}$ and $\mathrm{Sr}$ measurement $(5 \mathrm{~mL})$ and for urea measurement $(1 \mathrm{~mL})$, if applicable. All sample aliquots were immediately filtered $(0.2 \mu \mathrm{m})$ and stored at $4{ }^{\circ} \mathrm{C}$ or frozen until analysis. At the end of the $8 \mathrm{~h}$ experiment, precipitates were collected by centrifugation.

Saturation indices $(\log \mathrm{Q} / \mathrm{K}$ where $\mathrm{Q}$ is the ion activity product and $\mathrm{K}$ is the corresponding equilibrium constant) were calculated for calcite and strontianite using The Geochemist Workbench (GWB) Software package (Release 4.0, Rockware Inc., Denver, CO; Bethke, 2002) and the supplied Lawrence Livermore National Laboratory (LLNL) thermodynamic database. The GWB package calculates activity coefficients using the B-dot extension of the Debye-Hückel method of Helgeson (1969). Initial conditions for the experiments were undersaturated (saturation index $\leq 0$ ) with respect to both calcite and strontianite.

\subsection{Measurement of Urea}

Urea was measured by an adaptation of the spectrophotometric method reported by Knorst et al. (1997). Briefly, a filtered sample (1 $\mathrm{mL}$ ) containing urea was reacted with $0.25 \mathrm{~mL}$ of an ethanolic solution of $p$-dimethylaminobenzaldehyde ( $4 \% \mathrm{w} / \mathrm{v})$ and sulfuric acid ( $4 \% \mathrm{w} / \mathrm{v})$. After $5 \mathrm{~min}$, the colored product was measured by UV spectrophotometry (Shimadzu UV-1601, Shimadzu Corporation, Kyoto, Japan) at 422 $\mathrm{nm}$. Samples were compared with external standards prepared in nanopure water; previous experience indicated that calibration curves for standards in nanopure water and in the synthetic groundwater were identical.

\subsection{Measurement of $\mathrm{Ca}, \mathrm{Sr}$ by ICP-AES}

$\mathrm{Ca}$ and $\mathrm{Sr}$ were measured in both solid and aqueous samples by inductively coupled plasma with atomic emission spectrophotometric detection (ICP-AES). Precipitates were initially dissolved in nitric acid. Filtered aqueous samples were acidified with nitric acid $(\mathrm{pH}<2)$. The metal concentrations were measured on a Thermo Jarrell Ash Iris II system (Thermo Elemental, Franklin, MA, USA). The instrument was operated and calibrated in accordance with the manufacturer's instructions. A sample spike and replicate analyses were performed to assure accuracy and precision of the analysis. Calibration standards were prepared from commercial stock solutions. An internal standard of yttrium was spiked to each sample and all standards at $2 \mathrm{ppm}$ to correct for any matrix problems. A continuing calibration verification standard and a continuing calibration blank were analyzed throughout the anal- 
ysis to monitor instrument performance. The wavelengths used for analysis were $317.933,346.446$, and $371.030 \mathrm{~nm}$ for $\mathrm{Ca}, \mathrm{Sr}$, and Y, respectively.

\subsection{XRD}

For X-ray diffraction (XRD) analyses of the precipitates, the material was hand-ground and mounted on glass slides. The samples were analyzed with a Bruker D-8 Advance X-ray Diffractometer (Bruker AXS, Congleton, Cheshire, UK) with a $\mathrm{Cu}$ tube source $(30 \mathrm{~mA}-40$ $\mathrm{kV}$ ), single Gobels mirror and a scintillation detector. Bruker "Eva" software was used to evaluate the samples.

\subsection{ESEM and EDS}

Direct examination and elemental analysis of the precipitates produced during the experiments were conducted with environmental scanning electron microscopy (ESEM) and energy dispersive X-ray spectroscopy (EDS). Images were collected with a Philips XL30 ESEM equipped with a LAB6 electron source (FEI Co., Hillsboro, OR, USA). Within the ESEM sample chamber, samples were maintained at $3{ }^{\circ} \mathrm{C}$ with a Peltier cooling stage. The wet samples were deposited onto 6 $\mathrm{mm}$ stainless steel coupons (polished to $6 \mu \mathrm{m}$ ) designed to fit into the metal cup supplied with the Peltier stage. The cells were not fixed. Water vapor pressure was varied from 5.9 to 4.1 torr, corresponding to relative humidity in the sample chamber of 100 to $73 \%$, respectively. Relative humidity was varied during imaging in attempts to improve visualization of individual bacterial cells. Accelerating voltages were varied from $7 \mathrm{keV}$ to $10 \mathrm{keV}$.

To image bacterial cells, $B$. pasteurii cells deposited on a stainless steel coupon were placed under vacuum in a Hummer V sputter coater (Technics, Inc., Advanced Technologies, San Diego, CA, USA) fitted with a gold target and coated with $\sim 10 \mathrm{~nm}$ of gold. The sample was then imaged in high vacuum mode at $10 \mathrm{keV}$.

The ESEM was equipped with a Princeton Gamma-Tech EDS system (Princeton Gamma-Tech, Princeton, NJ, USA) capable of detecting light elements. The system allows determination of bulk elemental composition as well as estimates of relative atomic proportions within the sample utilizing standardless quantitative analysis. X-ray collection was performed at $15 \mathrm{keV}$ accelerating voltage with an Ultra Thin Window to obtain total counts of 100,000 to 150,000 (2-5\% dead time) with good spectral resolution.

\subsection{ToF-SIMS Analysis and Determination of Sputter Depth by AFM}

To characterize $\mathrm{Sr}$ incorporation with depth into the precipitates, time-of-flight secondary ion mass spectrometry (ToF-SIMS) analyses were performed using a Charles Evans \& Associates instrument (Schueler et al., 1990), in the user facility at the Image and Chemical Analysis Laboratory at Montana State University. The solid particles were pressed into indium foil and coated with $10 \mathrm{~nm}$ of gold before mounting in the sample holder to prevent charging. The sample was then admitted to the analysis chamber and analyzed at a base pressure of $\sim 5 \times 10^{-9}$ torr. The primary ion was a microfocused $\mathrm{Ga}^{+}$gun operated at $\sim 1 \mathrm{nA}$ dc current at $+15 \mathrm{keV}$ energy. The sample was held at $3 \mathrm{keV}$ potential; hence, the impact energy of the primary ions was 12 $\mathrm{keV}$. The mass resolution $(\mathrm{m} / \Delta \mathrm{m} \sim 1200)$ was sufficient to distinguish inorganic from organic ions. The analytical protocol consisted of collecting a positive ion mass spectrum, sputtering the sample, and then repeating the processes. The sample was sputtered for 2.5, 5.0, 7.5, 10, $12.5,15,20,35$, and $50 \mathrm{~min}$, resulting in a total of 10 mass spectra at 10 different depths. During the depth profiling $2 \times 10^{-6}$ torr oxygen was leaked into the chamber and an $80 \times 80 \mu \mathrm{m}$ area was sputtered employing the primary beam previously described. Care was exercised to maintain the emission current of the liquid metal ion gun during sputtering. The instrument was pumped down to $\sim 5 \times 10^{-9}$ torr before analysis, and within each sputtered zone only a $12 \times 12 \mu \mathrm{m}$ area was analyzed.

Atomic force microscopy (AFM; Digital Instruments Dimension 3100, Santa Barbara, CA, USA) was used to determine sputter depth for sputter depth profiling. A calcite crystal spar (Iceland Calcite $46 \mathrm{E}$ 1438; Ward's Natural Science, Rochester, NY) was used for the de-

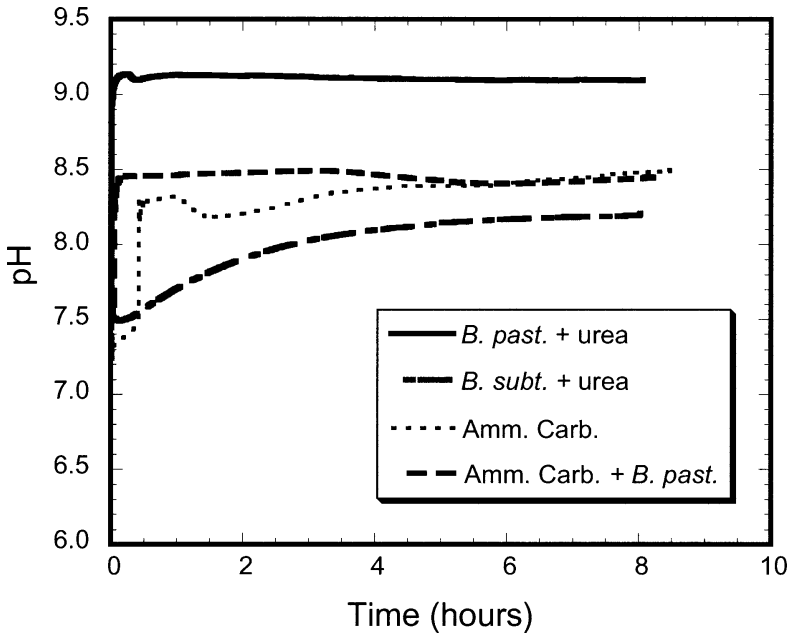

Fig. 1. $\mathrm{pH}$ trends in calcite precipitation experiments. Experiments conducted at $20^{\circ} \mathrm{C}$.

termination due to its flatness. The sample was sputtered for $10 \mathrm{~min}$ under the same conditions used for SIMS analysis, then imaged by AFM.

\subsection{X-ray Absorption Near-Edge Spectroscopy (XANES)}

X-ray absorption analysis was performed at Argonne National Laboratory's Advanced Photon Source on beamline 20 with bending magnet X-rays (PNC-CAT line 20-BM). A Si (111) double-crystal monochromator was used with a slit of approximately $1 \mathrm{~mm} \times 10 \mathrm{~mm}$ at $50 \mathrm{~m}$ from the source, detuned by $50 \%$ to reduce harmonics. Energy resolution was 3.5-4 eV. Detectors were custom ion chambers filled with $\mathrm{Ar} / \mathrm{N}_{2}$ gas mixtures (approx. 1:1 for transmission, and 1:0 for fluorescence).

Powdered strontium carbonate and strontium nitrate reference solids, and test samples were mounted as approximately $1 \mathrm{~mm}$ layers using Kapton tape. Beam alignment was based on use of fluorescent film and maximum fluorescence/absorbance at 16,200 $\mathrm{eV}$ ( $\mathrm{Sr}$ absorption edge is $16,105 \mathrm{eV})$. A zirconium metal foil was used for monochromator calibration (first absorption inflection point at 17,998 eV; Bearden and Burr, 1967). Four to five scans were collected and averaged for each sample. Pre-edge background subtraction and XANES normalization were performed by fitting linear polynomials separately to the pre-edge and post-edge regions.

\section{RESULTS AND DISCUSSION}

\subsection{Solution Chemistry Changes}

Upon introduction of the $B$. pasteurii to the synthetic groundwater containing urea, the $\mathrm{pH}$ rose to approximately 9.1 within the first quarter hour, and remained at that level for the duration of the experiment (Fig. 1). Urea measurements indicated that $30 \mathrm{mM}$ was hydrolyzed within the first hour; urea concentrations did not change over the next $7 \mathrm{~h}$ of the experiment (data not shown). The change in $\mathrm{pH}$ was correlated with the changes in $\mathrm{Ca}$ and $\mathrm{Sr}$; solution concentrations for both ions dropped dramatically within the first hour and remained at approximately the same concentrations for the rest of the experimental time period (Fig. 2). The saturation index for calcite at the end of the experiment was 1.1, as compared to an initial value of -0.2 . The production of white solids was visually observed within the first hour. In contrast, in the experimental system with $B$. subtilis no decrease in urea concentration was detected. 
(a)

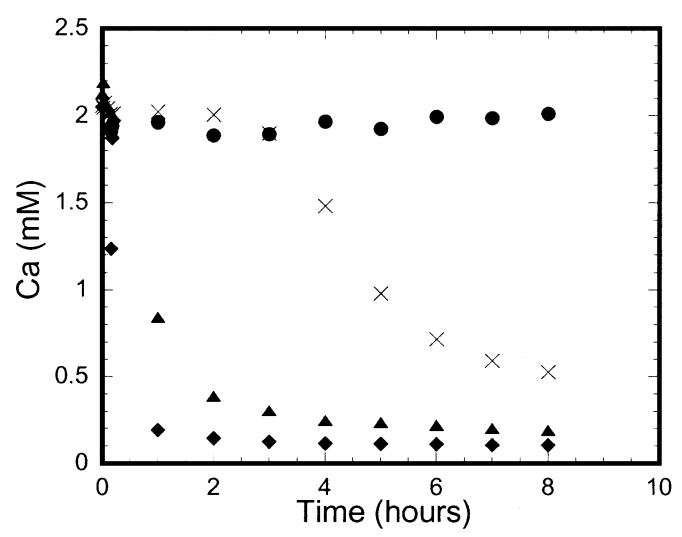

(b)

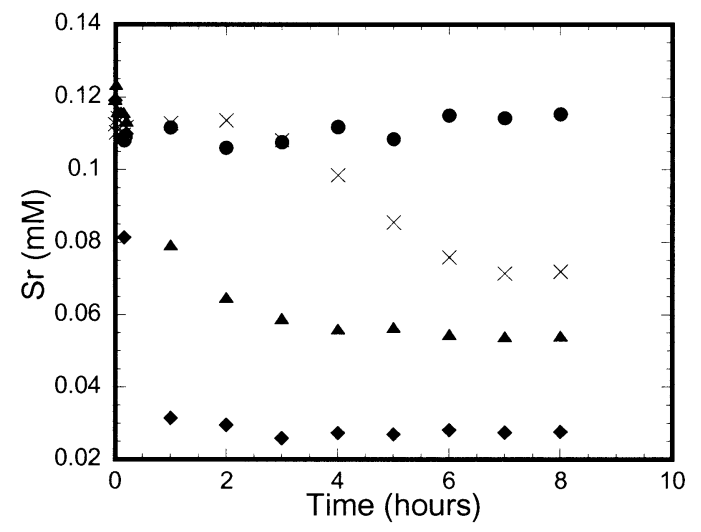

\section{- B. past. + urea $\quad$ B. Subt. + urea $\Delta$ Amm. carb. $\times$ Amm. carb. + B. past.} $20{ }^{\circ} \mathrm{C}$.

Although physiologic information (Atkinson and Fisher, 1991) and genomic information (Cruz-Ramos et al., 1997) confirm the presence of urease and urease genes in B. subtilis 186, this organism did not exhibit ureolytic activity under the conditions of these experiments, and therefore was a suitable nonureolytic control. The initial drop in $\mathrm{pH}$ observed with the $B$. subtilis may have been attributable simply to the initial mixing of the experimental solutions; the $B$. subtilis cell suspension was at $\mathrm{pH} 6.5$ before mixing with the $2 \times$ synthetic groundwater. And although a gradual increase in $\mathrm{pH}$ to a final value of 8.2 was observed (Fig. 1), no decreases in $\mathrm{Ca}$ and $\mathrm{Sr}$ concentrations were observed over the course of the experiment (Fig. 2), and no visible precipitates were formed after $8 \mathrm{~h}$.

Because pure "ammonium carbonate" was not available, it was not possible to precisely simulate the urea hydrolysis experiment in the abiotic precipitation experiments. The amount of inorganic carbon that was added in the abiotic experiments was similar to the increase that resulted from urea hydrolysis by $B$. pasteurii. However, the increase in alkalinity (and ammonium) was only half that of the urea hydrolysis experiment. Consequently our main goal was to compare the two abiotic treatments to each other, evaluating the effect of adding non-urea hydrolyzing cell surfaces. In addition, the ammonium carbonate experiments allowed us to extend the range of precipitation rates examined for their effect on $\mathrm{Sr}$ partitioning (see section 4.5). In both ammonium carbonate treatments the $\mathrm{pH}$ eventually rose to approximately 8.5 (Fig. 1) and dissolved $\mathrm{Ca}$ and $\mathrm{Sr}$ decreased (Fig. 2). In both cases $\mathrm{Ca}$ and $\mathrm{Sr}$ removal occurred at a slower rate than with urea hydrolysis, as would be expected given that the alkalinity increase was approximately one half (i.e., $\mathrm{HCO}_{3}{ }^{-}$rather than $\mathrm{CO}_{3}{ }^{2-}$ ) of that which resulted from urea hydrolysis. However, in the presence of the $B$. pasteurii cells, the onset of $\mathrm{Ca}$ and $\mathrm{Sr}$ removal was delayed and the overall removal of the ions from solution after $8 \mathrm{~h}$ was reduced relative to the case without cells (Fig. 2). Final calcite saturation indices for the ammonium carbonate and ammonium carbonate + cells treatments were 1.0 and 1.4 , respectively. One might have expected that the addition of bacterial cell surfaces, which are known to have high binding capacities for metals (Douglas and Beveridge, 1998) and can serve as mineral nucleation sites (Ehrlich, 1999), would enhance the precipitation rate, but we did not observe any such enhancement. Friis et al. (2003) reported that $B$. subtilis cells caused decreased calcite saturation indices due to uptake of Ca on cell wall functional groups (Friis et al., 2003). This process could explain our observations, although the cell densities that Friis et al. (2003) reported to have an effect, on the order of $10^{11}$ cells $/ \mathrm{mL}$, were more than three orders of magnitude higher than what was tested here. Organic biomolecules associated with the cells may have suppressed calcite precipitation. LeBron and Suarez (1996) reported that dissolved organic carbon at concentrations $>0.05 \mathrm{mM}$ inhibits calcite growth (Lebron and Suarez, 1996). In the case of urea hydrolyzing $B$. pasteurii, it is possible that the active metabolism creates such strong gradients at the cell surface that the inhibiting effects of organic moieties are overcome.

\subsection{ESEM, EDS, and XRD of Precipitates}

Samples of the white solids that formed in the reaction vessels were examined by ESEM. The precipitates produced during bacterial ureolysis were roughly rhombohedral in shape, and generally $5-10 \mu \mathrm{m}$ on a side. Indentations and holes that correlated with the size and shape of the bacteria were clearly evident throughout the precipitates (Fig. 3a). The bacteria themselves were difficult to image with the sample preparation technique utilized for the ESEM of the crystals; gold coating of the bacteria and subsequent imaging (Fig. 3b) showed that the $B$. pasteurii cells were indeed of the size to match the observed holes in the precipitates. Apparently the precipitation occurred directly on and in the immediate vicinity of the cells, suggesting that the cells served as nucleation sites. In contrast, the crystals produced in the ammonium carbonate experiments without cells (Fig. 3c) showed no evidence of the holes, although the crystals were similar in overall size and shape to the ones generated by ureolysis. When the $B$. pasteurii cells were 


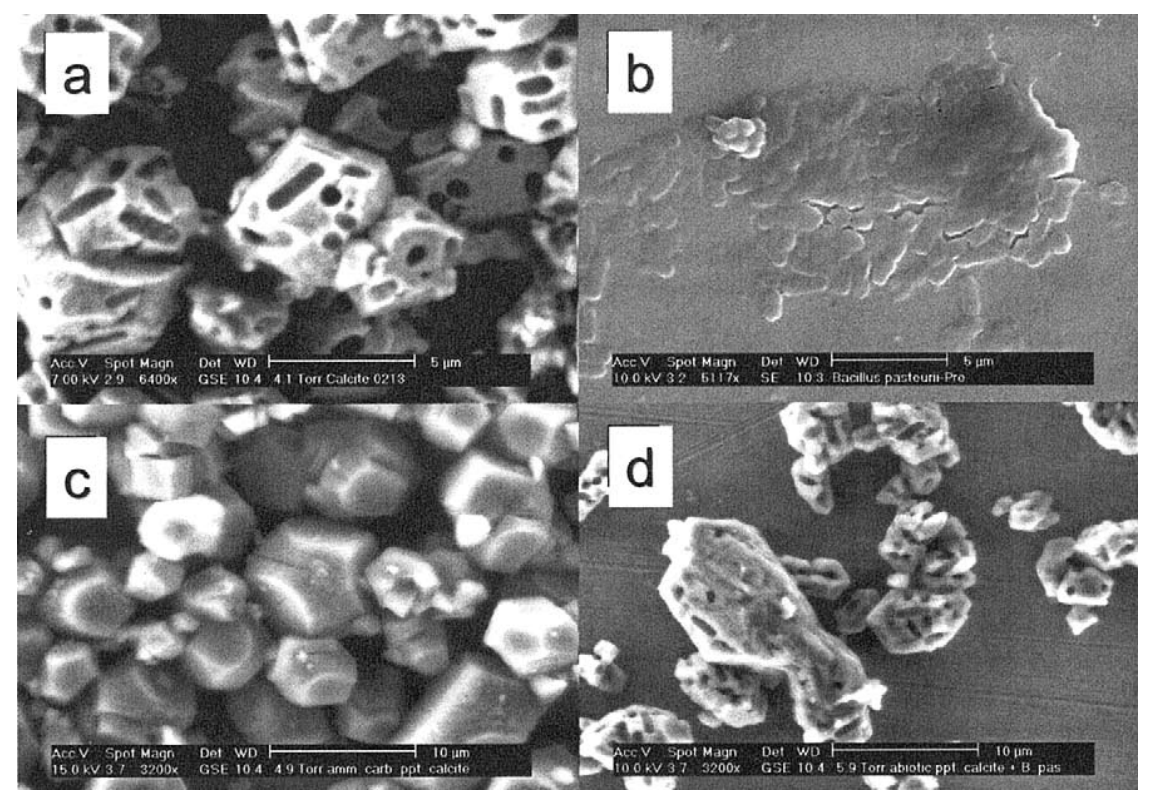

Fig. 3. Scanning electron micrographs of (a) calcite produced by $B$. pasteurii hydrolyzing urea, (b) gold coated $B$. pasteurii cells, (c) calcite produced by the addition of ammonium carbonate in the absence of cells, and (d) calcite produced by the addition of ammonium carbonate in the presence of $B$. pasteurii, but in the absence of urea.

added to the ammonium carbonate samples, in the absence of urea, similar holes were seen in the precipitates but the morphology of the precipitates was not as regular (Fig. 3d). The size range of the particles however was similar to the other precipitates, with dimensions generally on the order of 5-10 $\mu \mathrm{m}$. EDS spectra of all three types of precipitates were similar, clearly showing a large Ca peak and a smaller Sr peak (data not shown). XRD analyses of all of the precipitates indicated only the presence of calcite in the samples, although calculated saturation indices for strontianite at the conclusion of the precipitate-producing experiments were 3.3 to 3.5 .

\subsection{Sr:Ca Ratios in Precipitates}

Sputter depth profiling with ToF SIMS was used to determine whether the Sr concentration varied as a function of depth in the calcite crystals. The $\mathrm{Sr}: \mathrm{Ca}$ ratios shown in Figure 4 were calculated from the ion intensities for $m / z, 88(\mathrm{Sr})$ and $m / z, 40$ (Ca). The ratios were corrected for the mass selectivity of the detector, but not for the natural isotopic abundances of the elements; consequently the values are true isotopic ratios, rather than elemental ratios. The elemental ratios would be higher, by a factor of 1.17 . The depth into the precipitates was estimated from ToF SIMS experiments with reference calcite and AFM. In these studies, $10 \mathrm{~min}$ of sputtering time was correlated to a depth of $710 \AA$. In all three treatments, Sr was present at depth within the calcite, and was not just present as a surface phase. The $B$. pasteurii and urea treatment exhibited a consistently higher $\mathrm{Sr}$ :Ca ratio throughout the depth investigated (up to $\sim 350 \mathrm{~nm}$ ) as compared to the particulates generated by ammonium carbonate addition. In particular, the $\mathrm{Sr}: \mathrm{Ca}$ ratio appeared to be elevated near the surface of the particles. This result is consistent with precipitation in a batch system at low temperature, where the composition of the aqueous phase changes as precipitation proceeds (in this case, the solution becomes progressively enriched in $\mathrm{Sr}$ ), and ionic solid state diffusion is slow, hindering reequilibration of the solid with the aqeuous phase (Prieto et al., 1997). It is likely that this effect was most pronounced in the $B$. pasteurii + urea treatment because it resulted in the most calcite precipitation, and thus the solution composition changed to the greatest extent. The inclusion of $B$. pasteurii cells in the ammonium carbonate treatment did not significantly affect the near surface $\mathrm{Sr}$ :Ca ratios.

Elemental Sr:Ca ratios for the bulk precipitates were measured following acidic digestion and analysis by ICP-AES (Table 1). These data also demonstrate the enhanced uptake of

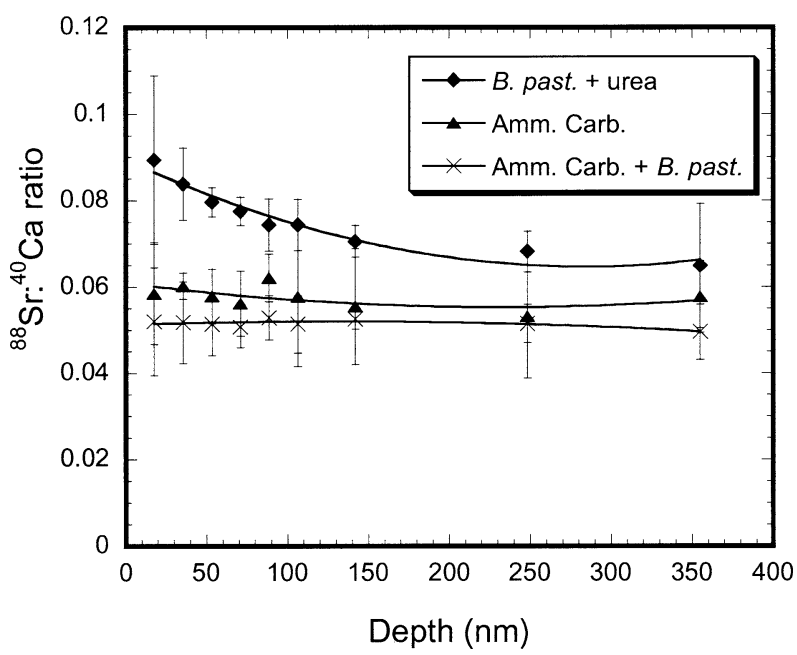

Fig. 4. Isotopic ratio of $\mathrm{Sr}$ :Ca with depth into the calcite precipitates, determined by ToF SIMS. Ratios were calculated from the ion intensities for $\mathrm{m} / z 88(\mathrm{Sr})$ and $\mathrm{m} / \mathrm{z} 40(\mathrm{Ca})$ 
Table 1. Sr:Ca ratios in precipitates measured by ICP-AES after acidic digestion.

\begin{tabular}{lc}
\hline \multicolumn{1}{c}{ Sample generated by: } & Sr:Ca \\
\hline B. pasteurii + urea & 0.044 \\
Ammonium carbonate & 0.032 \\
Ammonium carbonate + B. pasteurii & 0.027 \\
\hline
\end{tabular}

Sr into the precipitates generated by $B$. pasteurii and urea, relative to the ammonium carbonate generated samples. The precipitate generated by ammonium carbonate addition in the presence of $B$. pasteurii had a slightly lower Sr:Ca ratio than the ammonium carbonate treatment alone, but this lower ratio is likely due to the slower precipitation rate observed for the former system (discussed in section 4.5). For all three of the sample types, comparison with the ToF SIMS data shows that the bulk Sr:Ca ratios of the solids were considerably lower than the estimated ion ratios in the near surface, indicating that the ion ratio must have dropped significantly with increasing depth into the particles. As the particles were on the order of 5-10 $\mu \mathrm{m}$ in depth, and the ToF SIMS data were only acquired for approximately the outer $350 \mathrm{~nm}$ of the particles, only the outer $\sim 5-10 \%$ of the particles were analyzed by ToF SIMS. As previously noted, this outer layer represents calcite grown during the later stages of precipitation, when the $\mathrm{Sr}: \mathrm{Ca}$ ratio in solution is highest.

\subsection{Sr Coordination in Calcite}

Figure 5 shows X-ray absorption spectra for the experimental precipitates, along with reference spectra for $\mathrm{SrCO}_{3}$ and $\mathrm{Sr}\left(\mathrm{NO}_{3}\right)_{2}$ solids. The primary absorption edge inflection points for $\mathrm{SrCO}_{3}$ and $\mathrm{Sr}\left(\mathrm{NO}_{3}\right)_{2}$ were at $16,110 \mathrm{eV}$. Edge inflection points for the experimental samples were all at $16,111 \mathrm{eV}$. The reported standard value for the $\mathrm{Sr}$ absorption edge is $16,105 \mathrm{eV}$ (Bearden and Burr, 1967). Spectra for the experimental samples were essentially identical to each other, and clearly differ-

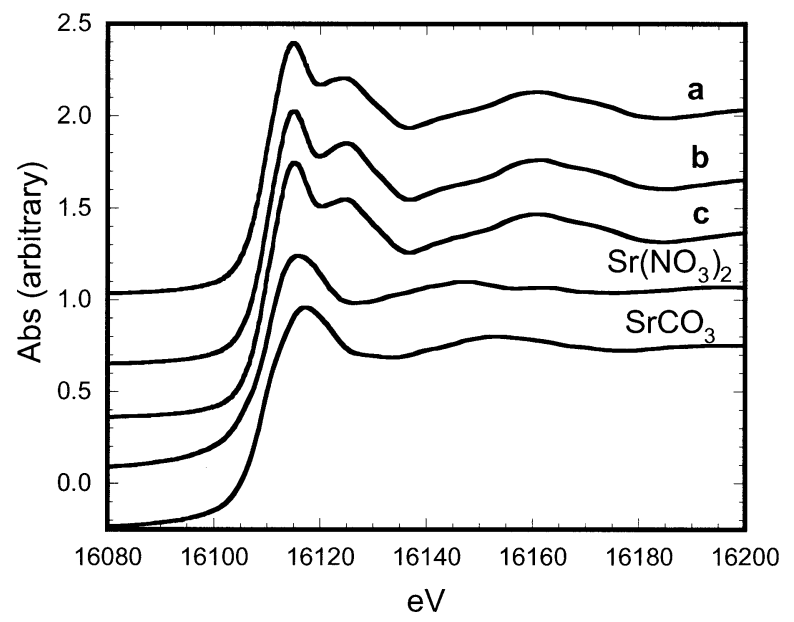

Fig. 5. Sr K-edge XANES of calcites generated in experimental treatments (a) B. pasteurii + urea, (b) ammonium carbonate, and (c) ammonium carbonate $+B$. pasteurii, compared to reference spectra for $\mathrm{SrCO}_{3}$ and $\mathrm{Sr}\left(\mathrm{NO}_{3}\right)_{2}$.

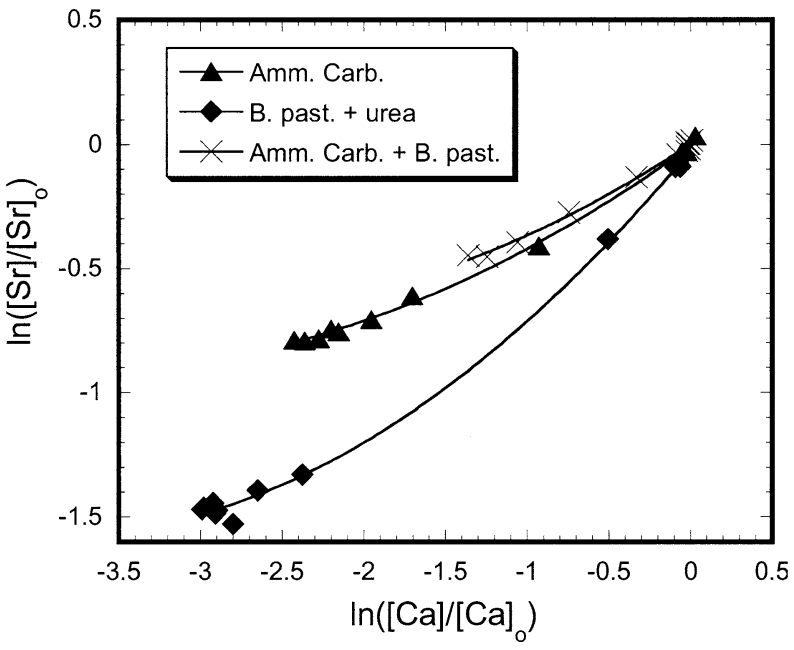

Fig. 6. Plot of $\ln \left(\mathrm{m}_{\mathrm{Sr}}{ }^{2+} j^{\mathrm{int}} \mathrm{m}_{\mathrm{Sr}}{ }^{2+}\right)$ vs. $\ln \left(\mathrm{m}_{\mathrm{Ca}}{ }^{2+} j^{\mathrm{int}} \mathrm{m}_{\mathrm{Ca}}{ }^{2+}\right)$ for the experimental treatments that resulted in calcite precipitation.

ent from the reference spectra for $\mathrm{SrCO}_{3}$ and $\mathrm{Sr}\left(\mathrm{NO}_{3}\right)_{2}$. Single peaks at approximately $16,118 \mathrm{eV}$ are seen in the XANES region $(0-30 \mathrm{eV}$ above the absorption edge) for strontianite and strontium nitrate, while the spectra for the experimental treatments all show two peaks at approximately 5 and $14 \mathrm{eV}$ above the absorption edge. In addition, peaks in the EXAFS region, above approximately $16,150 \mathrm{eV}$, can be discerned in the experimental treatments, and there are no equivalent features for the strontianite sample. Solutions of $\mathrm{Sr}$ salts were not analyzed in this project, however a spectrum for $100 \mathrm{mM} \mathrm{SrCl} \mathrm{m}_{2}$ was reported by Parkman et al. (1998). This spectrum also shows a single peak in the XANES region, indicating that $\mathrm{Sr}$ is not present as a hydrated ion in the experimental samples.

Our spectra were similar to those reported by Pingitore et al. (1992) in their study of $\mathrm{Sr}$ incorporation into natural and synthetic calcites. Pingitore et al. (1992) interpreted their spectra as evidence for $\mathrm{Sr}$ substitution at $\mathrm{Ca}$ structural sites. In an EXAFS analysis of calcite, strontianite, and samples of $\mathrm{Sr}$ coprecipitated with $\mathrm{CaCO}_{3}$, Parkman et al. (1998) verified an approximately hexacoordinate structure for strontium in the calcite lattice. Overall, the most logical interpretation for the $\mathrm{Sr}$ coprecipitated with $\mathrm{CaCO}_{3}$ in these experiments is that $\mathrm{Sr}$ is present predominantly as a substitution in the calcite lattice. This interpretation is consistent with the results of the ToF SIMS analyses, which showed Sr present in the interior of the calcite, rather than present only as a sorbed surface phase.

\subsection{Strontium Distribution Coefficients}

Plots of $\ln \left(\mathrm{m}_{\mathrm{Sr}}{ }^{2+} \rho^{\text {init }} \mathrm{m}_{\mathrm{Sr}}{ }^{2+}\right)$ vs. $\ln \left(\mathrm{m}_{\mathrm{Ca}}{ }^{2+} \rho^{\mathrm{init}} \mathrm{m}_{\mathrm{Ca}}{ }^{2+}\right)$ for the 3 experiments in which calcite precipitation occurred are nonlinear, indicating that $\mathrm{D}_{\mathrm{EX}}$ is not constant (Fig. 6). These results show that in general the $B$. pasteurii plus urea experiment was associated with greater partitioning of $\mathrm{Sr}$ into calcite (overall slope $=0.49$, based on $\mathrm{t}=0$ and $\mathrm{t}=8$ concentrations) than either of the nonureolytic controls (overall slope $=0.33$ ), and the distribution coefficient decreased over time.

One of the goals of this study was to assess whether $\mathrm{Sr}$ partitioning in calcite precipitated as a result of ureolytic ac- 


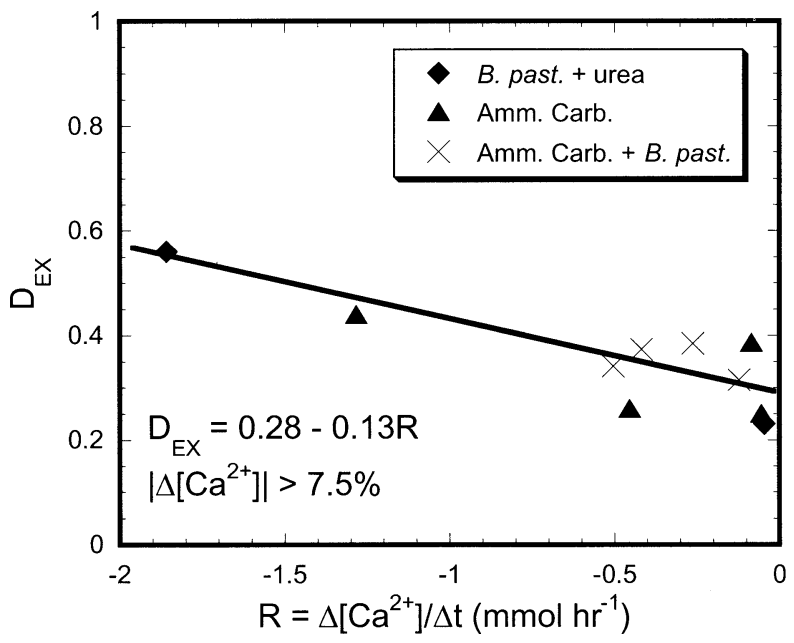

Fig. 7. Values of $D_{\text {Ex }}$ plotted as a function of the average precipitation rate for the calcite precipitation experiments. Precipitation rates were estimated by evaluating the changes in solution concentration of $\mathrm{Sr}$ and $\mathrm{Ca}$ that occurred between hourly samplings of the solution over the $8 \mathrm{~h}$ course of the experiments. Values of $\mathrm{D}_{\mathrm{EX}}$ and precipitation rates for which there was less than $7.5 \%$ change in the concentration of calcium were excluded, because the uncertainty in our determination of individual concentrations was estimated to be $3 \%$ and differences between measurements of less than $\sim 6 \%$ are insignificant.

tivity is fundamentally different from $\mathrm{Sr}$ partitioning in calcite precipitated by abiotic processes or if urea hydrolysis influences $\mathrm{Sr}^{2+}$ partitioning solely by its effects on the rate of calcite precipitation. As previously discussed, high rates of precipitation are known to result in greater $\mathrm{Sr}$ partitioning into calcite. Figure 7 shows values of $\mathrm{D}_{\mathrm{EX}}$ plotted as a function of the average precipitation rate for the experiments shown in Figure 6. Precipitation rates were estimated by evaluating the changes in $\mathrm{Ca}$ concentration that occurred between hourly samplings of the solution phase. The results shown in Figure 7 suggest that all of the experiments can be described by a single trend and support the hypothesis that biotic urea hydrolysis influences $\mathrm{Sr}^{2+}$ partitioning primarily through the precipitation rate, rather than through a structural effect related to the bacterial surface or particulars of metabolism. The addition of bacterial cell surfaces to the ammonium carbonate treatment did not appear to enhance $\mathrm{Sr}$ uptake, through either an increased precipitation rate or some other mechanism, although the appearance of the crystals did suggest that the cells served as nucleation sites. The apparent primary dependence of $\mathrm{Sr}$ partitioning on the precipitation rate is in contrast to the findings of Roden et al. (2002), where Sr partitioning into biogenic siderite was greater than into abiotically generated siderite even when the respective precipitation rates were comparable. One potential explanation offered for that result was that the reduced proton activity engendered by bacterial iron reduction could have increased the tendency for $\mathrm{Sr}^{2+}$ to sorb to reactive sites on the siderite surfaces, thereby promoting surface enrichment and entrapment of $\mathrm{Sr}$ during crystal growth. It is possible that this mechanism may have also been operative during our experiments with the alkalinity-producing urea hydrolysis reaction, but its effect was overwhelmed by the high rates of precipitation generated in our experiments. In our experiments, extensive precipitation occurred over the course of a few hours; in the Roden et al. (2002) experiments, Sr uptake into solids occurred over the course of weeks.

Extrapolation of the trend shown in Figure 7 to very slow precipitation rates yields a value of $D_{\mathrm{EX}}$ of 0.28 . This value is much higher than the values $(0.02-0.1)$ reported in the summary of Rimstidt et al. (1998) and at the higher end of the range reported by Curti (1999). The high value (0.40) of Curti (1999) is taken from Mucci and Morse (1983) who reported results of $\mathrm{Sr}^{2+}$ partitioning into calcite with significant amounts of $\mathrm{Mg}$ and is probably not applicable to the current study. The large discrepancy between our value of $\mathrm{D}_{\mathrm{EX}}$ and previous studies may be due to the mode of calcite precipitation. Previous studies have focused on the growth of calcite on preexisting calcite seed crystals. In this study the dominant mode of precipitation was nucleation in a system free of preexisting calcite. Reeder et al. (1999) found that divalent trace metal ions both smaller and larger than calcium substitute into calcium sites within the calcite structure with varying degrees of local distortion. The smaller crystal sizes associated with nucleated calcite may more readily accommodate the distortion than larger crystals and permit more extensive substitution. Lebron and Suarez (1996) suggest that for many subsurface waters the concentration of dissolved organic carbon may be high enough to effectively eliminate crystal growth as a precipitation mode, leaving nucleation as the most important precipitation mode. If nucleation is indeed the most important mode of calcite precipitation in soil and groundwater, the higher values of $D_{E X}$ reported in the current study may not be so extreme, when considering potential distribution coefficients that could be achieved in an engineered system. Whether in fact nucleation is the dominant mode of precipitation in natural groundwater is however unclear. Tobin et al. (2000) reported Sr concentrations of 40 to $50 \mathrm{ppm}$ for calcites collected from the SRPA in eastern Idaho. If these calcite compositions are representative of partitioning with current groundwater $\left(\mathrm{Sr}^{2+}: \mathrm{Ca}^{2+}\right.$ ratios of 0.00285 , unpublished data), a much lower value (0.02) of $\mathrm{D}_{\mathrm{EX}}$ is suggested. This lower value is consistent with the ranges reported by Curti (1999) and Rimstidt et al. (1998), and argues against nucleation as the dominant precipitation mode for the SRPA. However, the current groundwater may not have the same composition as that responsible for the precipitated calcite (Tobin et al., 2000).

\section{CONCLUSIONS}

To develop a remediation approach based on the in situ immobilization of a contaminant in a solid phase, it is necessary to maximize the sequestration of the contaminant, verify that it is stable over the long-term, and be able to control the process in time and place. The research reported here contributes to initial efforts to address the first two needs with respect to $\mathrm{Sr}$ coprecipitation in calcite. The results support earlier suggestions that enhanced $\mathrm{Sr}$ uptake is associated with carbonates generated by biotic processes (Ferris et al., 1995; Warren et al., 2001), in particular by bacterial ureolysis. Our data indicate that this enhanced uptake is primarily due to the high precipitation rates that can be generated by bacterial ureolysis. Work is currently underway in our laboratories to investigate this phenomenon more rigorously, with detailed kinetic analysis 
and modeling. The effects on the strontium partitioning of any physical controls exerted by the cell surfaces appear to be negligible. The main role of the ureolytic cells appears to be in changing the solution geochemistry. XANES analyses indicate that the $\mathrm{Sr}$ incorporated into calcite through the activity of urea hydrolyzing organisms is present in the form of a solid solution, ensuring the relative stability of ${ }^{90} \mathrm{Sr}$ immobilized in calcite through this mechanism. As Pingitore et al. (1992) point out, "no significant alteration of the strontium in geological calcites should occur, barring the actual dissolution of the material." This robustness bodes well for the potential application of the proposed remediation approach as a long-term containment and stabilization strategy for ${ }^{90} \mathrm{Sr}$ in environments such as the SRPA where calcite is stable.

Acknowledgments - We thank B. White, C. Watkins and A. Erickson at the INEEL for assistance with the ICP-AES, ESEM/EDS and XRD analyses respectively, and R. Avci of the Image and Chemical Analysis Laboratory at Montana State University for assistance with the ToFSIMS and AFM analyses. We are grateful to C. Palmer and also to three anonymous reviewers for their constructive comments. Funding for this work was provided by the INEEL through the U.S. Department of Energy contract DE-AC07-99ID13727, and by the U.S. DOE Environmental Management Science Program through award DE-FG0799ER 15025. Use of the Advanced Photon Source was supported by the U.S. DOE, Office of Science, Office of Basic Energy Sciences, under Contract No. W-31-109-Eng-38. Access to the beamlines managed by the Pacific Northwest Consortium Collaborative Access Team (PNCCAT) was made available and facilitated with the expertise, advice, and generous assistance of S. Heald and R. Gordon of the Argonne National Laboratory. The beamline is supported by US DOE Office of Science grant no. DE-FG03-97ER45628.

\section{Associate editor: P. A. Maurice}

\section{REFERENCES}

Atkinson M. R. and Fisher S. H. (1991) Identification of genes and gene-products whose expression is activated during nitrogen-limited growth in Bacillus subtilis. J. Bacteriol. 173, 23-27.

Bearden J. A. and Burr A. F. (1967) Reevaluation of X-ray atomic energy levels. Rev. Mod. Phys. 39, 125-142.

Bethke C. M. (2002) The Geochemist's Workbench: A User's Guide to Rxn, Act2, Tact, React, and Gtplot (Release 4.0). University of Illinois, Urbana, IL.

Buczynski C. and Chafetz H. S. (1991) Habit of bacterially induced precipitates of calcium-carbonate and the influence of medium viscosity on mineralogy. J. Sediment. Petrol. 61, 226-233.

Castanier S., Le Metayer-Levrel G., and Perthuisot J. P. (1999) Cacarbonates precipitation and limestone genesis-The microbiogeologist point of view. Sediment. Geol. 126, 1-4 9-23.

Cruz-Ramos H., Glaser P., Wray L., Jr., and Fisher S. (1997) The Bacillus subtilis ureABC operon. J. Bacteriol. 179, 3371-3373.

Curti E. (1999) Coprecipitation of radionuclides with calcite: Estimation of partition coefficients based on a review of laboratory investigations and geochemical data. Appl. Geochem. 14, 433-445.

Davis J. A., Fuller C. C., and Cook A. D. (1987) A model for trace-metal sorption processes at the calcite surface-Adsorption of $\mathrm{Cd}^{2+}$ and subsequent solid-solution formation. Geochim. Cosmochim. Acta 51, 1477-1490.

Doerner H. A. and Hoskins W. M. (1925) Co-precipitation of radium and barium sulfates. J. Am. Chem. Soc. 47, 662-675.

Douglas S. and Beveridge T. J. (1998) Mineral formation by bacteria in natural microbial communities. FEMS Microbiol. Ecol. 26, 79-88.

Ehrlich H. L. (1996) Geomicrobiology. Marcel Dekker.

Ehrlich H. L. (1999) Microbes as geologic agents: Their role in mineral formation. Geomicrobiol. J. 16, 135-153.

Ferris F. G. and Stehmeier L. G. (1992) U.S. Patent, Pat. No. 5,143,155. Bacteriogenic Mineral Plugging.
Ferris F. G., Fratton C. M., Gertis J. P., Schultzelam S., and Lollar B. S. (1995) Microbial precipitation of a strontium calcite phase at a groundwater discharge zone near Rock Creek, British Columbia, Canada. Geomicrobiol. J. 13, 57-67.

Ferris F. G., Stehmeier L. G., Kantzas A., and Mourits F. M. (1996) Bacteriogenic mineral plugging. J. Can. Petrol. Technol. 35, $56-61$.

Ferris F. G., Fyfe W. S., and Beveridge T. J. (1987) Bacteria as nucleation sites for authigenic minerals in a metal-contaminated lake sediment. Chem. Geol. 63 (3-4), 225-232.

Friis A. K., Davis T. A., Figueira M. M., Paquette J., and Mucci A. (2003) Influence of Bacillus subtilis cell walls and EDTA on calcite dissolution rates and crystal surface features. Environ. Sci. Technol. 37, 2376-2382.

Fujita Y., Ferris F. G., Lawson D. L., Colwell F. S., and Smith R. W. (2000) Calcium carbonate precipitation by ureolytic subsurface bacteria. Geomicrobiol. J. 17, 305-318.

Hammes F., Seka A., de Kniff S., and Verstraete W. (2003) A novel approach to calcium removal from calcium-rich industrial wastewater. Water Res. 37, 699-704.

Helgeson H. C. (1969) Thermodynamics of hydrothermal systems at elevated temperatures and pressures. Am. J. Sci. 267, 729-804.

Kepner R. L. and Pratt J. R. (1994) Use of fluorochromes for direct enumeration of total bacteria in environmental-samples-Past and present. Microbiol. Rev. 58, 603-615.

Knobel L. L., Bartholomay R. C., Cecil L. D., Tucker B. J., and Wegner S. J. (1992) Chemical Constituents in the Dissolved and Suspended Fractions of Ground Water from Selected Sites, Idaho National Engineering Laboratory and Vicinity, 1989. U.S. Geological Survey, Idaho.

Knorst M. T., Neubert R., and Wohlrab W. (1997) Analytical methods for measuring urea in pharmaceutical formulations. J. Pharm. Biomed. Anal. 15, 1627-1632.

Lebron I. and Suarez D. L. (1996) Calcite nucleation and precipitation kinetics as affected by dissolved organic matter at $25^{\circ} \mathrm{C}$ and $\mathrm{pH}$ >7.5. Geochim. Cosmochim. Acta 60, 2765-2776.

Lorens R. B. (1981) Sr, Cd, Mn and Co distribution coefficients in calcite as a function of calcite precipitation rate. Geochim. Cosmochim. Acta 45, 553-561.

McGenity T. J. and Sellwood B. W. (1999) New approaches to studying the microbial precipitation of carbonate minerals. Sediment. Geol. $126(1-4), 5-8$.

Mobley H. L. and Hausinger R. P. (1989) Microbial ureases: Significance, regulation, and molecular characterization. Microbiol Rev. 53, $85-108$.

Mucci A. and Morse J. W. (1983) The incorporation of $\mathrm{Mg}^{2+}$ and $\mathrm{Sr}^{2+}$ into calcite overgrowths-Influences of growth-rate and solution composition. Geochim. Cosmochim. Acta 47, 217-233.

Parkman R. H., Charnock J. M., Livens F. R., and Vaughan D. J. (1998) A study of the interaction of strontium ions in aqueous solution with the surfaces of calcite and kaolinite. Geochim. Cosmochim. Acta 62, $1481-1492$.

Pingitore N. E. and Eastman M. P. (1986) The coprecipitation of $\mathrm{Sr}^{2+}$ with calcite at $25{ }^{\circ} \mathrm{C}$ and 1 atm. Geochim. Cosmochim. Acta 50, 2195-2203.

Pingitore N. E., Lytle F. W., Davies B. M., Eastman M. P., Eller P. G., and Larson E. M. (1992) Mode of incorporation of $\mathrm{Sr}^{2+}$ in calciteDetermination by X-ray absorption-spectroscopy. Geochim. Cosmochim. Acta 56, 1531-1538.

Prieto M., Fernandez Gonzalez A., Putnis A., and Fernandez Diaz L. (1997) Nucleation, growth, and zoning phenomena in crystallizing $(\mathrm{Ba}, \mathrm{Sr}) \mathrm{CO}_{3}, \mathrm{Ba}\left(\mathrm{SO}_{4}, \mathrm{CrO}_{4}\right),(\mathrm{Ba}, \mathrm{Sr}) \mathrm{SO}_{4}$, and $(\mathrm{Cd}, \mathrm{Ca}) \mathrm{CO}_{3}$ solid solutions from aqueous solutions. Geochim. Cosmochim. Acta 61, 3383-3397.

Ramachandran S. K., Ramakrishnan V., and Bang S. S. (2001) Remediation of concrete using micro-organisms. ACI Mater. J. 98, 3-9.

Reeder R. J., Lamble G. M., and Northrup P. A. (1999) XAFS study of the coordination and local relaxation around $\mathrm{Co}^{2+}, \mathrm{Zn}^{2+}, \mathrm{Pb}^{2+}$, and $\mathrm{Ba}^{2+}$ trace elements. Am. Miner. 84 (7-8), 1049-1060. 
Riley R. G. and Zachara J. M. (1992) Chemical Contaminants on DOE Lands and Selection of Contaminant Mixtures for Subsurface Science Research. U.S. Department of Energy, Office of Energy Research.

Rimstidt J. D., Balog A., and Webb J. (1998) Distribution of trace elements between carbonate minerals and aqueous solutions. Geochim. Cosmochim. Acta 62, 1851-1863.

Roden E. E., Leonardo M. R., and Ferris F. G. (2002) Immobilization of strontium during iron biomineralization coupled to dissimilatory hydrous ferric oxide reduction. Geochim. Cosmochim. Acta 66, 2823-2839.

Schueler B., Sander P., and Reed D. A. (1990) A time-of-flight secondary ion microscope. Vacuum 41 (7-9), 1661-1664.

Schultzelam S. and Beveridge T. J. (1994) Nucleation of celestite and strontianite on a cyanobacterial S-layer. Appl. Environ. Microbiol. 60, 447-453.

Stocks-Fischer S., Galinat J. K., and Bang S. S. (1999) Microbiological precipitation of $\mathrm{CaCO}_{3}$. Soil Biol. Biochem. 31, 1563-1571.
Teng H. H., Dove P. M., and De Yoreo J. J. (2000) Kinetics of calcite growth: Surface processes and relationships to macroscopic rate laws. Geochim. Cosmochim. Acta 64, 2255-2266.

Tesoriero A. J. and Pankow J. F. (1996) Solid solution partitioning of $\mathrm{Sr}^{2+}, \mathrm{Ba}^{2+}$, and $\mathrm{Cd}^{2+}$ to calcite. Geochim. Cosmochim. Acta 60, 1053-1063

Tobin K. J., Colwell F. S., Onstott T. C., and Smith R. (2000) Recent calcite spar in an aquifer waste plume: A possible example of contamination driven calcite precipitation. Chem. Geol. 169 (3-4), 449-460.

Warren L. A., Maurice P. A., Parmar N., and Ferris F. G. (2001) Microbially mediated calcium carbonate precipitation: Implications for interpreting calcite precipitation and for solid-phase capture of inorganic contaminants. Geomicrobiol. J. 18, 93-115.

Wiedemeier T. H., Rifai H. S., Newell C. J. and Wilson J. T. (1999) Natural Attenuation of Fuels and Chlorinated Solvents. Wiley.

Wood W. W. and Low W. H. (1986) Aqueous geochemistry and diagenesis in the Eastern Snake River plain aquifer system, Idaho. Geol. Soc. Am. Bull. 97, 1456-1466. 


\section{Appendix D:}

\section{Design and validation of ureC-based primers for groundwater detection of urea- hydrolyzing bacteria.}

By T.L.T. Gresham, P.P. Sheridan, M.E. Watwood, Y. Fujita, and F.S. Colwell.

In Geomicrobiology Journal. 24:353-364 (2007). 


\title{
Design and Validation of ureC-based Primers for Groundwater Detection of Urea-Hydrolyzing Bacteria
}

\author{
Tina L. T. Gresham and Peter P. Sheridan \\ Department of Biological Sciences, Idaho State University, Pocatello, ID, USA
}

Mary E. Watwood

Department of Biological Sciences, Northern Arizona University, Flagstaff, AZ, USA

Yoshiko Fujita

Biotechnology Department, Idaho National Laboratory, Idaho Falls, ID, USA

\author{
Frederick S. Colwell \\ College of Oceanic and Atmospheric Sciences, Oregon State University, Corvallis, OR, USA
}

\begin{abstract}
Polymerase chain reaction primers based on the ure $\mathrm{C}$ gene are described for use in detecting diverse groundwater ureahydrolyzing bacteria. Six degenerate primers were designed and evaluated for their ability to detect the gene encoding the large catalytic subunit of urease, ureC. Five combinations of these primers were tested pair-wise and displayed an overlapping detection range for bacterial isolates. Pair $\mathrm{L} 2 \mathrm{~F} / \mathrm{L} 2 \mathrm{R}$ exhibited the greatest detection range for described bacterial species and for bacterial isolates from groundwater samples belonging to the bacterial divisions Firmicutes, Actinobacteria, and the $\alpha, \beta$, and $\gamma$ subdivisions of Proteobacteria. Primers L2F/L2R exhibited a greater detection range than previously described ure $\mathrm{C}$-specific primers, and amplified novel ure $\mathrm{C}$ sequences from groundwater isolates in the genera Hydrogenophaga, Acidovorax, Janthinobacterium, and Arthrobacter. A comparative phylogenetic analysis of ure $\mathrm{C}$ and 16S rRNA genes was performed to determine the utility of groundwater ure $\mathrm{C}$ sequence information as a phylogenetic marker for ureolytic species. Our results were consistent with previous analyses of urease genes which demonstrated that the ure $\mathrm{C}$ gene has undergone lateral transfer and is not a robust phylogenetic marker. However, the ureC-specific primers, L2F/L2R, demonstrate a broad detection range for ureolytic species, and can serve to enhance functional diversity analyses of ureolytic bacteria.
\end{abstract}

Received 20 February 2006; accepted 17 May 2007.

Special thanks to David Reed for helpful discussions pertaining to this research and for reviewing and revising this manuscript. Many thanks to Erin O'Leary-Jepsen and Michelle Andrews of the ISU Molecular Research Core Facility for their assistance with DNA sequencing. The U.S. Department of Energy (DOE) Environmental Management Science Program (EMSP) provided funding for this work. Research at the INL is performed under the DOE Idaho Operations Office Contract DE-AC07-99ID13727.

Address correspondence to Tina L.T. Gresham, Department of Biological Sciences, Idaho State University, Pocatello, ID 83209-8007. E-mail: Tina.Gresham@aphis.usda.gov
Keywords bioremediation, groundwater, molecular ecology, primer design

\section{INTRODUCTION}

Decades of nuclear energy production and research has resulted in soil and groundwater contamination by toxic metals and radionuclides at many Department of Energy (DOE) sites (Riley et al. 1992). A remediation approach for slowing the transport of metals and divalent radionuclides ( $\operatorname{such}$ as ${ }^{90} \mathrm{Sr}^{2+}$ ) by sequestration within carbonate minerals was recently proposed and evaluated (Fujita et al. 2000, 2004). The remediation strategy involves stimulating native subsurface microbial communities to generate chemical conditions favoring carbonate mineral precipitation and co-precipitation of ${ }^{90} \mathrm{Sr}^{2+}$. Subsurface amendment with urea can stimulate in situ bacterial urea hydrolysis (producing ammonium and carbonate ions) and promote carbonate precipitation and co-precipitation of divalent metal cations and radionuclides. This method represents an effective strategy for immobilizing contaminants in the calcium-dominated aquifers of the arid western United States (Fujita et al. 2000; Warren et al. 2001; Fujita et al. 2004).

In such a remediation strategy, it is essential to monitor the progression of in situ ureolysis and subsequent generation of alkaline conditions. This is problematic because the products of urea hydrolysis have many potential fates in the subsurface. Ammonium and carbonate may become assimilated into microbial biomass, irretrievably sorbed to the aquifer matrix, blended indiscernibly into the background chemistry of the subsurface system, or lost due to groundwater flow away from monitoring wells. Therefore, molecular-based methods that measure urease gene copy number, or quantify urease gene expression rates in groundwater samples, can be indicative of 
how the ureolytic bacterial community is responding during field-scale experimentation.

Molecular characterization of a functional gene in mixed environmental samples requires specific and efficient detection of the target sequence. This study describes a PCR-based method for detecting urease genes in diverse environmental bacterial species. ure $\mathrm{C}$ was chosen as the target gene for these analyses because it is the largest of the genes coding for urease functional subunits and because it contains several regions of highly conserved sequence that are suitable as PCR priming sites. ure $\mathrm{C}$-specific PCR primers have been previously described (Collier et al. 1999; Morou-Bermudez and Burne 1999; Reed 2001; Koper et al. 2004), however, these primers were designed to target a single species or a narrow range of bacterial species. The primers described in this study were designed to maximize the detection range of bacterial ure $\mathrm{C}$ sequences that might be present in an aquifer environment selected for urea hydrolysisbased remediation research. In addition, these primers were used to obtain ureC gene sequence data from bacterial groundwater isolates, which were used in a comparative phylogenetic analysis with 16S rDNA sequences for the purpose of determining the utility of inferring species identity based on ureC sequence data. To our knowledge, this is the first report of a urease-specific PCR-based method for broad species-range detection of environmentally relevant bacteria.

\section{METHODS}

Groundwater Sampling. Groundwater samples were collected from 2 wells that access the Snake River Plain aquifer (SRPA) in southeastern Idaho. Samples from the Second Owsley well $\left(43^{\circ} 48^{\prime} \mathrm{N}, 112^{\circ} 38^{\prime} \mathrm{W}\right)$ were collected in June 2001 from an interval between 82.6 and 94.4 meters below land surface (mbls). Water temperature and $\mathrm{pH}$ at this interval averaged $14.0^{\circ} \mathrm{C}$ and $8.0^{\circ} \mathrm{C}$ respectively. Samples from the UP- 1 well $\left(43^{\circ} 31^{\prime} \mathrm{N}\right.$, $112^{\circ} 03 \mathrm{~W}$ ) were collected in September 2002 from an interval between 82.3 and 84.4 mbls. Water temperature and $\mathrm{pH}$ averaged $12.9^{\circ} \mathrm{C}$ and $7.0^{\circ} \mathrm{C}$, respectively. General SRPA water chemistry has been previously described (Knobel et al. 1992; Link and Mink 2002). Groundwater samples were collected in sterile Pyrex media bottles and stored on ice for no more than 6 hours prior to processing.

Bacterial Cultivation and Isolation from Groundwater Samples. Groundwater samples were serially diluted and spread onto R2A agar (Difco, Sparks, MD) and trypticase soy agar (TSA; BBL, Cockeysville, MD). Plates were incubated at room temperature $\left(\sim 22^{\circ} \mathrm{C}\right)$ for 3 weeks. Visibly unique bacterial colonies were selected and restreaked to achieve isolated cultures. Isolated cultures were stored at $-20^{\circ} \mathrm{C}$ in Miller LB broth (Difco) containing 15\% (vol./vol.) glycerol.

Urease-Positive and -Negative Bacterial Control Strains. Type strains from the American Type Culture Collection (Manassas, VA) were used as urease-positive and -negative controls in culture-based and molecular-based urease assays.
Urease positive strains: Sporosarcina pasteuri ATCC 11859, Corynebacterium glutamicum ATCC 13032, Streptococcus salivarius ATCC 13419, Bacillus subtilis ATCC 6051, Rhizobium meliloti ATCC 10310, Pseudomonas aeruginosa ATCC 10145, Proteus vulgaris ATCC 13315, and Staphylococcus aureus ATCC 12600. Urease-negative strain: Escherichia coli ATCC 25922.

Urease Activity Assays. Isolates and type strains were tested for the ability to hydrolyze urea using urea agar (Difco), a colorimetric $\mathrm{pH}$ indicator medium that changes color in response to ammonia evolution (resulting from ureolysis). Petri plates were sealed with parafilm (to avoid diffusion of ammonia between plates) and incubated at room temperature for 3 weeks. Cultures were scored positive for urease activity if the agar color changed from pale orange $(\sim \mathrm{pH} 6.9)$ to pink or fuchsia $(\sim \mathrm{pH}$ 7.6 or higher). Cultures were scored negative for urease activity if the agar color did not change (from pale orange) or if the agar turned yellow ( $\sim \mathrm{pH} 6.6$ or below).

DNA Isolation. Cultures of groundwater isolates were prepared as described previously. ATCC strains were cultured using ATCC suggested protocols, except for Sporosarcina pasteuri, which was grown overnight at $37^{\circ} \mathrm{C}$ in brain-heart infusion broth (BHI) containing $2 \%$ urea (wt./vol., Acros, NJ, USA). Genomic DNA was isolated from each pure culture using the Qiagen DNeasy tissue lysis kit (Valencia, CA) following manufacturer protocols.

ureC-Specific PCR Primer Design. The following ureC gene sequences from the GenBank database at NCBI 〈http://www.ncbi.nlm.nih.gov〉 were used to create deduced amino acid and nucleic acid alignments (with conserved codon positions) (MegAlign, DNAStar, Madison, WI): Actinobacillus pleuropneumoniae U89957, Actinomyces naeslundii AF056321, Bacillus halodurans AP001507, Sporosarcina pasteuri X78411, Bacillus sp. D14439, Bacillus subtilis Z99122, Bordetella bronchiseptica AF000579, Corynebacterium glutamicum AJ251883, Klebsiella aerogenes M36068, Lactobacillus fermentum D10605, Mycobacterium tuberculosis AE007047, Prochlorococcus marinus AF242489, Proteus mirabilis M31834, Pseudomonas aeruginosa PAO1 AE004900, Rhodobacter sphaeroides AF195122, Sinorhizobium meliloti AL591790, Staphylococcus xylosus X74600, Streptococcus salivarius U35248, Streptomyces coelicolor A3(2) AL939108, Synechococcus sp. PCC 7002 AF035751, Synechocystis sp. PCC 6803 D90903, Vibrio parahaemolyticus AB038238, Yersinia enterocolitica L24101, and Yersinia pestis AF095636. Degenerate PCR primers were designed in forward and/or reverse directions to target conserved regions within the aligned sequences.

Amplification, Cloning, and Sequencing of ureC Genes from Bacterial Groundwater Isolates. ureC-targeted primers were evaluated for functionality in PCR with genomic DNA extracts (as template DNA) from urease-positive and -negative control strains and groundwater isolates. Each reaction contained 1X PCR buffer, $1.5 \mathrm{mM} \mathrm{MgCl} 2,1.25$ units Taq DNA polymerase (Promega, Madison, WI), $0.25 \mathrm{mM}$ each dNTP (Roche 
Molecular Biochemicals, Indianapolis, IN), 400 to $800 \mathrm{ng}$ nonacetylated bovine serum albumin (Sigma Chemical Company, St. Louis, MO), $1.5 \mu \mathrm{M}$ each forward and reverse primer, and 10 to $20 \mathrm{ng}$ of genomic DNA template. General cycling parameters were: initial denaturation for $5 \mathrm{~min}$ at $94^{\circ} \mathrm{C} ; 30$ cycles of denaturation for $1 \mathrm{~min}$ at $94^{\circ} \mathrm{C}$, annealing for $1.5 \mathrm{~min}$ at 45 to $57^{\circ} \mathrm{C}$, extension for $2 \mathrm{~min}$ at $72^{\circ} \mathrm{C}$; and final extension for $15 \mathrm{~min}$ at $72^{\circ} \mathrm{C}$. Amplifications were performed a minimum of 2 times.

The QIAquick Spin kit (Qiagen) was used to purify PCR products prior to cloning. Purified PCR products were ligated and cloned using the TOPO TA Cloning kit with pCR 2.1-TOPO vector and TOP10 One Shot competent Escherichia coli cells (Invitrogen, Carlsbad, CA). Plasmid DNA was extracted and purified using the QIAprep Miniprep kit (Qiagen) and subsequently used as template in sequencing reactions. Primers M13F (-20) and M13R were used to sequence cloned inserts. Sequencing reactions were prepared using the ABI Big Dye Terminator v. 3.0 Cycle Sequencing Ready Reaction Kit with AmpliTaq DNA polymerase, with FS chemistry. Sequences were determined using an ABI Prism automated sequencer model 377 (Applied Biosystems, Foster City, CA) at the Molecular Research Core Facility at Idaho State University (Pocatello, ID). Both strands of PCR amplicons were completely sequenced. Contiguous sequences were assembled and proofread for ambiguous base calls using the BioEdit software package (version 5.0.6). Accession numbers for ureC sequences are given in Figures 2 and 3.

Amplification and Sequencing of $16 S$ rRNA Genes from Bacterial Groundwater Isolates. 16S rRNA gene amplicons were obtained by PCR for ten of the bacterial isolates used in this study. Each reaction contained: 1X PCR buffer, $1.5 \mathrm{mM}$ $\mathrm{MgCl}_{2}, 1.25$ units Taq DNA polymerase (Promega), $0.25 \mathrm{mM}$ each dNTP (Roche), 0.05\% IgePal (Sigma), $1.0 \mu \mathrm{M}$ each primer $8 \mathrm{~F}$ and $1492 \mathrm{R}$, and 10 to $20 \mathrm{ng}$ of genomic DNA template. Cycling parameters were as follows: initial denaturation for $5 \mathrm{~min}$ at $94^{\circ} \mathrm{C} ; 30$ cycles of denaturation for $1 \mathrm{~min}$ at $94^{\circ} \mathrm{C}$, annealing for $1.5 \mathrm{~min}$ at $53^{\circ} \mathrm{C}$, extension for $2 \mathrm{~min}$ at $72^{\circ} \mathrm{C}$; and a final extension for $7 \mathrm{~min}$ at $72^{\circ} \mathrm{C}$. Sequencing reactions for each isolate were prepared with primers 8F, 907R, 704F, and 1492R (Pace et al. 1986; Weisburg et al. 1991). Sequencing was performed as described here, however PCR amplicons were not cloned prior to sequencing. Accession numbers for 16S rRNA gene sequences are given in Figure 1.

ureC Phylogenetic Analyses. Seventy bacterial ureC sequences (or putative ure $\mathrm{C}$ sequences) spanning the entire length of the gene were retrieved from the GenBank database or the bacterial unfinished genomes site at NCBI 〈http://www.ncbi.nlm.nih.gov〉. Putative ure C sequences from unfinished genome sequencing projects were retrieved by performing BLAST (Altschul et al. 1990) searches against individual unfinished genomes using known ureC sequences. An additional 8 partial $u r e C$ sequences ( $~ 389$ bases long) were obtained from groundwater bacterial isolates by PCR using primers $\mathrm{L} 2 \mathrm{~F}$ and $\mathrm{L} 2 \mathrm{R}$. Sequences were used to create deduced amino acid alignments (with conserved codon positions) (MegAlign).
Two independent data sets were created; one set containing full-length sequences from GenBank, and the other containing the full-length sequences from GenBank and the ure $\mathrm{C}$ gene sequence fragments (minus primer sequences) from the groundwater isolates. In the latter data set, all full-length sequences were cropped to match the approximate size and position of the ure $\mathrm{C}$ gene sequence amplicons from the groundwater isolates. Alignments were analyzed with PAUP (Phylogenetic Analysis Using Parsimony, version 4.0b10, Sinauer Associates, 2002) to examine the phylogenetic relationships between sequences. Phylogenetic analyses of each data set were based on alignments of 599 amino acid positions (full-length sequences) and 137 amino acid positions (cropped sequences). Distance analyses were performed by PAUP using the neighbor-joining algorithm (using mean character distances), with Jukes Cantor (with equal rates), HKY 85, and Kimura 2 and 3 parameter correction models. The resultant trees were rooted by designating all cyanobacterial sequences as a monophyletic out-group.

16S rRNA Gene Phylogenetic Analysis. Seventy-seven 16S rRNA gene sequences retrieved from the GenBank database and 8 16S rRNA sequences from groundwater isolates (minus primer sequences) were collected for alignment using MegAlign. The alignment, based on 1286 nucleotide positions, was analyzed using PAUP. A distance analysis was performed using the neighbor-joining algorithm and Jukes Cantor (with equal rates) HKY 85, and Kimura 2 and 3 parameter correction models. The resultant trees were rooted by designating all cyanobacterial sequences as a monophyletic out-group. Species selected for the 16S rRNA analysis represent the same group of taxa used in the ure $\mathrm{C}$ phylogenetic analyses.

\section{RESULTS AND DISCUSSION}

Culture Isolation and Urease Assays. Unique colonies were picked from spread plates inoculated with groundwater from the Second Owsley or UP-1 wells. Fifty-one unique colony types were isolated on spread plates containing either TSA or R2A. Isolates were determined to be unique based on gel electrophoresis profiles produced by the ERIC-PCR method (Versalovic et al. 1991) (data not shown). There were twice as many unique colony types observed on R2A than on TSA, probably because the lower-nutrient R2A formulation better simulated the oligotrophic conditions of the aquifer (Reasoner and Geldreich 1985).

The isolates were screened for urease activity using a colorimetric urea agar method. Urea hydrolysis was not determined for 4 isolates that were unable to grow on this medium. Thirty of the remaining 47 isolates were scored as urease-positive and 17 isolates were scored as urease-negative (Table 1). Urea agar is routinely used for determining urease activity in rapidly growing bacterial species that are constitutively expressing urease or that are capable of hydrolyzing urea at a high rate (Difco Manual, Difco Laboratories, Sparks, MD). For example, ureolysis by Proteus, Shigella, and Salmonella species is apparent within 


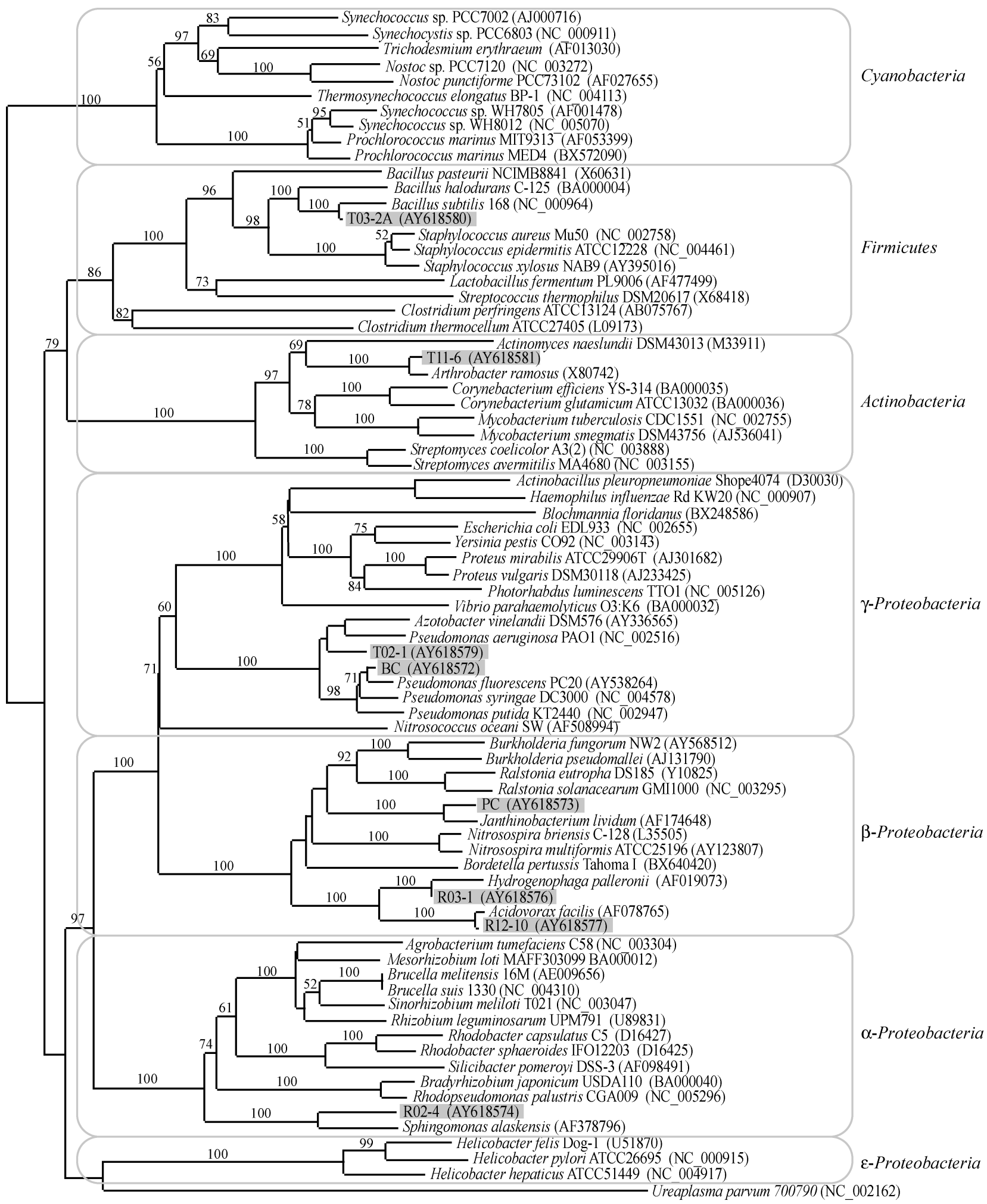

0.01 substitutions/site

FIG. 1. Phylogeny of 16S rRNA gene sequences belonging to known ureolytic strains and bacterial isolates from the Snake River Plain Aquifer, estimated by distance analysis using the neighbor-joining algorithm (Jukes Cantor correction) in PAUP. GenBank accession numbers are given parenthetically. Gray boxes indicate sequences obtained from groundwater isolates. Numbers at nodes indicate bootstrap values based on 1,000 resamplings; values less than 50\% are not shown. Scale bar indicates $1 \%$ nucleotide substitutions. 
TABLE 1

Urease-positive and -negative bacterial strains obtained from culture collections and the Snake River Plain aquifer, and PCR conditions used to test ureC-specific degenerate PCR primers

\begin{tabular}{|c|c|c|c|c|c|c|c|c|}
\hline \multirow[b]{5}{*}{ Isolate: } & \multirow[b]{5}{*}{ Urease $^{d}$} & \multicolumn{7}{|c|}{ PCR results with degenerate primer pairs ${ }^{b}$} \\
\hline & & Forward primer & $\mathrm{L} 2 \mathrm{~F}$ & $\mathrm{SF}$ & SF & SF-3 & SF-3 & ureC-F \\
\hline & & Reverse primer & L2R & SR & SR-2 & SR & SR-2 & ureC-R \\
\hline & & Amplicon size (base pairs) ${ }^{a}$ & 394 & 451 & 580 & 277 & 406 & 323 \\
\hline & & Optimal annealing temp $\left({ }^{\circ} \mathrm{C}\right)$ & 57 & 53 & 53 & 57 & 45 & 50 \\
\hline Sporosarcina pasteuri & + & & + & + & + & + & + & + \\
\hline Bacillus subtilis & + & & - & + & + & + & + & + \\
\hline Streptococcus salivarius & + & & + & + & + & + & + & + \\
\hline Corynebacterium glutamicum & + & & + & + & + & + & + & + \\
\hline Staphylococcus aureus & + & & + & + & + & - & - & - \\
\hline Rhizobium meliloti & + & & + & - & + & - & + & + \\
\hline Pseudomonas aeruginosa & + & & + & + & + & + & + & + \\
\hline Proteus vulgaris & + & & + & + & + & + & + & + \\
\hline Escherichia coli & - & & - & - & - & - & - & - \\
\hline $\mathrm{PC}^{c}($ Janthinobacterium sp.) & + & & + & - & - & - & - & + \\
\hline $\mathrm{BC}^{c}$ (Pseudomonas sp.) & + & & + & - & - & - & - & - \\
\hline $\mathrm{R} 01-2$ & + & & - & - & - & - & - & - \\
\hline $\mathrm{R} 01-3$ & + & & + & - & + & - & - & + \\
\hline $\mathrm{R} 02-2$ & + & & + & - & + & + & - & + \\
\hline $\mathrm{R} 02-4$ & + & & + & - & - & - & - & + \\
\hline R02-6 & + & & + & - & + & + & - & + \\
\hline $\mathrm{R} 02-7$ & + & & + & - & + & + & + & + \\
\hline R03-1 (Hydrogenophaga sp.) & + & & + & - & + & - & + & + \\
\hline R11-3 & + & & + & - & - & - & - & - \\
\hline R11-4 & + & & - & - & - & - & - & - \\
\hline R12-1 & + & & + & - & + & - & - & + \\
\hline $\mathrm{R} 12-3$ & + & & - & - & + & - & + & + \\
\hline R12-4 & + & & - & - & - & - & - & - \\
\hline R12-5 & + & & + & - & - & - & - & - \\
\hline R12-7 & + & & - & - & + & - & + & + \\
\hline R12-9 & + & & + & - & - & - & - & - \\
\hline R12-10 (Acidovorax sp.) & + & & + & - & + & - & - & + \\
\hline R13-5 & + & & + & - & - & - & - & + \\
\hline R21-1 & + & & + & - & - & - & - & - \\
\hline T01-13 & + & & + & - & - & + & + & + \\
\hline T01-15 & + & & + & - & + & + & + & + \\
\hline T02-1 (Pseudomonas sp.) & + & & + & - & - & - & - & + \\
\hline T02-12 & + & & - & + & - & + & + & - \\
\hline T03-1 & + & & + & - & - & - & - & + \\
\hline T03-2A & + & & + & - & - & - & - & - \\
\hline T03-2B & + & & + & - & - & - & + & + \\
\hline T11-6 & + & & + & + & + & + & - & + \\
\hline T12-2 & + & & + & ND & ND & ND & ND & ND \\
\hline T31-1 & + & & - & - & - & - & + & + \\
\hline R01-4 & - & & - & - & - & - & - & - \\
\hline R01-5 & - & & - & - & - & - & - & - \\
\hline R02-3 & - & & - & - & - & - & - & - \\
\hline R02-5 & - & & - & - & - & - & - & - \\
\hline
\end{tabular}

(Continued on next page) 
TABLE 1

Urease-positive and -negative bacterial strains obtained from culture collections and the Snake River Plain aquifer, and PCR conditions used to test ureC-specific degenerate PCR primers (Continued)

\begin{tabular}{|c|c|c|c|c|c|c|c|c|}
\hline \multirow[b]{2}{*}{ Isolate: } & \multirow[b]{2}{*}{ Urease $^{d}$} & \multicolumn{7}{|c|}{ PCR results with degenerate primer pairs ${ }^{b}$} \\
\hline & & $\begin{array}{l}\text { Forward primer } \\
\text { Reverse primer } \\
\text { Amplicon size (base pairs })^{a} \\
\text { Optimal annealing temp }\left({ }^{\circ} \mathrm{C}\right)\end{array}$ & $\begin{array}{c}\mathrm{L} 2 \mathrm{~F} \\
\mathrm{~L} 2 \mathrm{R} \\
394 \\
57\end{array}$ & $\begin{array}{c}\text { SF } \\
\text { SR } \\
451 \\
53\end{array}$ & $\begin{array}{c}\text { SF } \\
\text { SR-2 } \\
580 \\
53\end{array}$ & $\begin{array}{l}\text { SF-3 } \\
\text { SR } \\
277 \\
57\end{array}$ & $\begin{array}{c}\text { SF-3 } \\
\text { SR-2 } \\
406 \\
45\end{array}$ & $\begin{array}{l}\text { ure } \mathrm{C}-\mathrm{F} \\
\text { ure } \mathrm{C}-\mathrm{R} \\
323 \\
50\end{array}$ \\
\hline $\mathrm{R} 02-8$ & - & & - & - & - & - & - & - \\
\hline R11-2 & - & & - & - & - & - & - & - \\
\hline R11-6 & - & & - & - & - & - & - & - \\
\hline R12-2 & - & & - & - & - & - & - & - \\
\hline R13-4 & - & & - & - & - & - & - & - \\
\hline R43-1 & - & & - & - & - & - & - & - \\
\hline R52-2 & - & & - & - & - & - & - & - \\
\hline T01-4 & - & & - & - & - & - & - & - \\
\hline T01-6 & - & & - & - & - & - & - & - \\
\hline T02-3 & - & & ND & - & - & - & - & - \\
\hline T02-5 & - & & - & - & - & - & - & - \\
\hline T02-8 & - & & - & - & - & - & - & - \\
\hline T32-1 & - & & - & - & - & - & - & - \\
\hline
\end{tabular}

${ }^{a}$ Refers to the predicted length (in nucleotides) of PCR-targeted DNA fragment (including primer sequences), based on ureC sequence of Sporosarcina pasteuri.

${ }^{b}$ Predicted amplicon was produced (+); predicted amplicon was not produced (-).

${ }^{c}$ Cultures isolated from UP-1 groundwater (other unknown isolates were from Owsley-2 well).

${ }^{d}$ Indicated by alkalinity production on urease agar.

ND (not determined).

minutes to hours. The groundwater isolates grew and hydrolyzed urea relatively slowly, as evidenced by the longer time period required for color change to occur in the urea medium (days to weeks). A false-positive result, due to spontaneous protein hydrolysis within the medium, was theoretically possible (Difco Manual), but not observed in uninoculated controls or ureasenegative controls using Escherichia coli. In addition, urea agar observations were corroborated by DNA-based assays for urease genes. For example, ure $\mathrm{C}$ genes were not detected in any of the isolates that were scored as urease-negative by the urea agar method (Table 1).

ureC Primer Design and Testing. From ure $\mathrm{C}$ sequence alignments, 5 conserved regions were identified as potential priming sites and appeared to be unique to urease when compared to the GenBank database by BLAST. These highly conserved regions contained, or were located near, key amino acid residues involved in catalysis and substrate binding, or were ligands to the urease nickel metallocenter (Mobley et al. 1995). Six PCR primers (3 forward and 3 reverse) were designed from these 5 conserved regions; nucleic and deduced amino acid sequences for each primer are shown in Table 2 . Table 1 provides data for 5 combinations of these primers that were tested in PCR using genomic DNA from control strains and groundwater isolates. Primer combinations not presented did not produce amplified products or produced abundant non-specific products. Optimal annealing temperatures were determined empirically for each primer pair and are reported in Table 1, along with the expected amplicon size, and the results of PCR with each control strain or isolate.

The urease-positive and -negative control strains included species from $\alpha$ - and $\gamma$-Proteobacterial subdivisions, and from the divisions Firmicutes and Actinobacteria. Each primer pair exhibited different detection efficiency for the urease-positive control strains (Table 1). The pair SF/SR-2 amplified the expected ure $\mathrm{C}$ fragment from all 8 urease-positive control strains, while the other pairs amplified it ureC from 6 or 7 of the 8 ureasepositive control strains (Table 1). Each of the 5 new primer pairs produced the expected amplicon when tested with genomic DNA from some, but not all, urease-positive groundwater isolates. None of the primer pairs were able to amplify the ureC target from every urease-positive strain tested, and the primer pairs demonstrated overlapping detection efficiency. The use of a suite of ure $\mathrm{C}$ primers together, or in separate reactions is an alternative approach to increasing the diversity of ure $\mathrm{C}$ targets detected in an environmental sample.

No PCR amplicons were produced when tested with DNA from the urease-negative control strain (Escherichia coli) or urease-negative groundwater isolates (Table 1). These results 
TABLE 2

ure $\mathrm{C}$ Gene-specific PCR primers designed in this study and by others

\begin{tabular}{lllccll}
\hline Primer & Direction & \multicolumn{1}{c}{ Primer sequence $^{a}$} & Position $^{b}$ & Degeneracy $^{c}$ & Amino acid $^{d}$ & Reference $^{2}$ \\
\hline SF & Forward & CAYGARGAYTGGGGWKCBAC & $661-680$ & 96 & HEDWGA & This study \\
SF-3 & Forward & GGYGGBGGMCAYGCHCCNGA & $835-854$ & 288 & GGGHAP & This study \\
SR & Reverse & TCWCCDACDCGBCCCATBGC & $1112-1093$ & 162 & AMGRVG & This study \\
SR-2 & Reverse & GCHGGRTTRATBGTRTAYTT & $1241-1222$ & 144 & KYTINP & This study \\
L2F & Forward & ATHGGYAARGCNGGNAAYCC & $286-305$ & 384 & IGKAGN & This study \\
L2R & Reverse & GTBSHNCCCCARTCYTCRTG & $680-661$ & 576 & HEDWGX & This study \\
ureC-F & Forward & TGGGCCTTAAAATHCAYGARGAYTGGG & $647-673$ & 24 & GLKIHEDW & (Reed 2001) \\
ureC-R & Reverse & GGTGGTGGCACACCATNANCATRTC & $970-946$ & 32 & DMXMVCHH & (Reed 2001) \\
- & Forward & AAGSTSCACGAGGACTGGGG & $655-674$ & 4 & KXHEDW & (Collier 1999) \\
- & Reverse & AGGTGGTGGCASACCATSAGCAT & $971-949$ & 4 & MLMVCHH & (Collier 1999) \\
\hline
\end{tabular}

${ }^{a}$ Primer sequence given in the $5^{\prime}$ to $3^{\prime}$ direction.

${ }^{b}$ Position numbering relative to the ure $\mathrm{C}$ sequence of Sporosarcina pasteuri.

${ }^{c}$ Represents the total number of possible primer sequence combinations when the degeneracy of the genetic code is considered.

${ }^{d}$ Amino acid sequence given in the $\mathrm{N}$ terminus to $\mathrm{C}$ terminus direction.

substantiate the efficacy of the colorimetric urea agar method for determining the absence of urease activity in these organisms. However, from our collection of urease positive isolates, 3 did not produce a ureC PCR amplicon with any of the novel primer pairs. Additional experiments were not performed to further investigate this finding; however, several possible explanations are plausible, including (1) the ure $\mathrm{C}$ target was not detected by the novel primers, (2) an alternative mechanism for urea hydrolysis exists in these species, such as the novel prokaryotic urea carboxylase (UCA) (Kanamori et al. 2004), or (3) the urease genes were plasmid-borne, as described for other ureolytic species (D’Orazio and Collins 1993a; Dupuy et al. 1997), and were not co-purified with the genomic DNA.

The detection range of the ure $\mathrm{C}$ primers designed in this study was compared to previously published ure $\mathrm{C}$ primers, ure $\mathrm{C}$ $\mathrm{F} /$ ure C-R (Reed, 2001). The ure $\mathrm{C}-\mathrm{F} /$ ure $\mathrm{C}-\mathrm{R}$ primers were considerably less degenerate (Table 2 ) and were based on an alignment of fewer species (Reed 2001). ure C-F/ureC-R primers amplified a ure $\mathrm{C}$ fragment from $70 \%$ of the ureolytic species included in this study, compared to the novel primer pair L2F/L2R, which amplified ure $\mathrm{C}$ from $79 \%$ of species tested. More importantly, the extra $9 \%$ of species detected by $\mathrm{L} 2 \mathrm{~F} / \mathrm{L} 2 \mathrm{R}$ were from groundwater isolates and represent previously undescribed putative ure $\mathrm{C}$ sequences. Although the primer pair L2F/L2R is highly degenerate, it demonstrates specificity and fidelity in amplifying ure C. L2F/L2R-generated amplicons from Sporosarcina pasteuri and Proteus vulgaris were an exact match to their respective ure $\mathrm{C}$ sequences in GenBank. L2F/L2R-generated amplicons from 10 groundwater isolates also produced highly significant sequence matches to previously reported ure $\mathrm{C}$ sequences. In addition, the L2F/L2R primers were evaluated in PCR using total community DNA extracted from groundwater, resulting in amplicons with high sequence similarity to known ure $\mathrm{C}$ genes (data not shown).
16S rRNA gene sequences from the same ten isolates (given parenthetically) revealed that they are closely related to the following known species: Acidovorax facilis (R12-10), Hydrogenophaga palleronii (R02-6), Hydrogenophaga taeniospiralis (R03-1), Janthinobacterium lividum (PC), Pseudomonas corrugata (BC), Pseudomonas anguilliseptica (T02-1), Pseudomonas saccharophila (R21-1), Sphingomonas xenophaga (R02-4), Arthrobacter ramosus (T11-6), and Bacillus licheniformis (T03-2A). None of these species have been previously reported to contain urease genes.

$16 S$ rRNA Gene Phylogenetic Analysis. 16S rRNA-based phylogenetic analysis was used to determine the relative phylogenetic affiliation of isolates compared to other known ureolytic bacterial species. The resulting neighbor-joining tree, using the Jukes Cantor correction model, was consistent with the accepted 16S rRNA-based phylogeny for prokaryotes (Figure 1). Bootstrap values were not significantly affected by other correction models, such as HKY 85 and Kimura 2 and 3 parameter models. The misgrouping of Ureaplasma urealyticum (Firmicutes) with the $\varepsilon$-Proteobacteria (bootstrap value $68 \%$ ) is likely due to the uneven coverage of species and the vast phylogenetic distance represented by the taxa in this analysis.

ureC Gene Phylogenetic Analyses. A neighbor-joining tree of ure $\mathrm{C}$ genes (Jukes Cantor correction model), translated and aligned with respect to amino acid codons, was constructed for the same group of species that was analyzed in the 16S rRNA phylogeny. Bootstrap values were not significantly affected by other correction models, as described here. The choice of Cyanobacteria as outgroup taxa (an ancestral ureolytic clade based on $16 \mathrm{~S}$ rRNA), was supported by a $97 \%$ bootstrap value (Figure 2).

In general, the analysis demonstrated that ure $\mathrm{C}$ genes do not exhibit a strict congruence with the $16 \mathrm{~S}$ rRNA-based phylogeny. The ingroup taxa divided into 2 groups, each with relatively high 


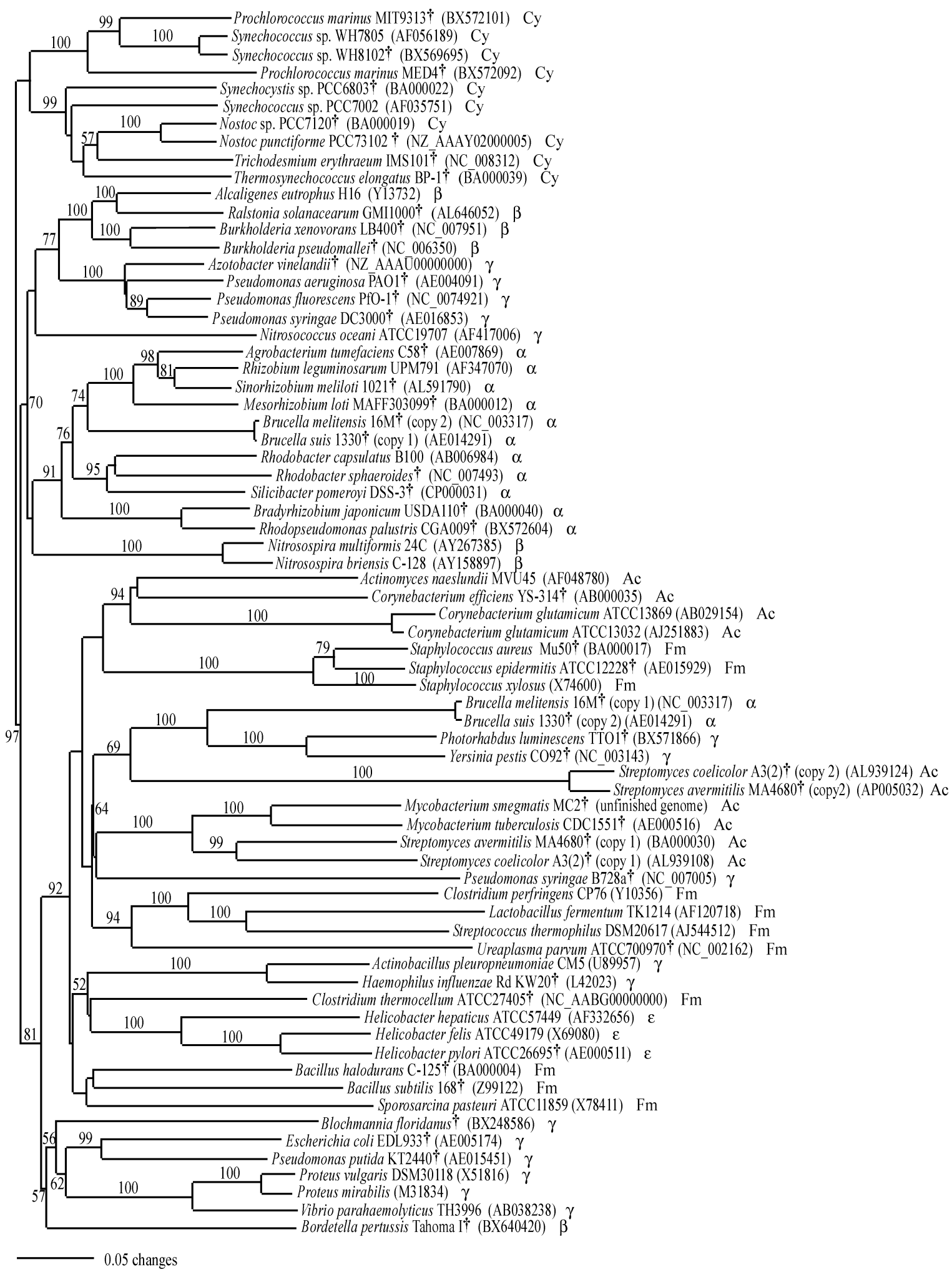

FIG. 2. Phylogeny of ureolytic bacterial species previously described in the GenBank database (accession numbers are given parenthetically), using full-length ure $\mathrm{C}$ sequences, translated and aligned with respect to codon positions. Phylogenetic relationships were estimated using PAUP, as described in Figure 1. Abbreviations to the right of taxa labels are as follows: $\mathrm{Cy}$, cyanobacteria; Fm, firmicutes; Ac, actinobacteria; $\alpha, \beta, \gamma$, and $\varepsilon$ refer to the sub-divisions of Proteobacteria. Numbers at nodes are as described in Figure 1. $\dagger$ indicates putative $u r e \mathrm{C}$ sequences identified by genome sequencing projects. Scale bar indicates $5 \%$ amino acid substitutions. 
bootstrap support. One group, supported at $70 \%$ bootstrap value, contained sequences from proteobacterial (Gram-negative) taxa, while the other group, supported at $81 \%$ bootstrap value, contained sequences belonging to the divisions Actinobacteria and Firmicutes (Gram-positive), plus an additional 17 sequences belonging to proteobacterial taxa. Seven of the 17 proteobacterial sequences (Blochmannia floridanus, Escherichia coli, Pseudomonas putida, Proteus vulgaris, Proteus mirabilis, Vibrio parahaemolyticus, and Bordetella pertussis) formed a weakly supported clade at $57 \%$ bootstrap value.

Due to the relatively weak bootstrap support for this clade, as well as the very short branch length leading to it, the reliability of this placement with the Gram-positive taxa is questionable. The other 10 proteobacterial sequences (Brucella melitensis copy 1, Brucella suis copy 2, Photorhabdus luminescens, Yersinia pestis, Pseudomonas syringae, Actinobacillus pleuropneumoniae, Haemophilus influenzae, Helicobacter hepaticus, Helicobacter felis, and Helicobacter pylori) grouped with the Gram-positive taxa in a strongly supported clade at $92 \%$ bootstrap value. These 10 proteobacterial sequences could possibly represent multiple independent transfer events from Grampositive to proteobacterial species. Similar results were reported in a study describing the phylogenetic orientation of ure $\mathrm{C}$ genes in ammonia oxidizing bacteria (Koper et al. 2004).

The presence of multiple urease gene copies within a single genome had not been revealed prior to the availability of numerous bacterial genome sequences, although native gel electrophoresis and activity staining of urease enzymes previously demonstrated that multiple urease isoforms commonly exist in bacteria (Burne and Chen 2000). The presence of 2 different copies of ure $\mathrm{C}$ has been identified by genome sequencing of at least 4 bacterial species (Streptomyces avermitilis, Streptomyces coelicolor, Brucella suis, and Brucella melitensis). Each of the two copies of ure $\mathrm{C}$ from Brucella suis and Brucella melitensis grouped within distinctly separate clades in the ure $\mathrm{C}$ trees (Figure 2), suggesting the presence of 2 independently evolving ureases, one of which was acquired more recently by lateral transfer. Possible mechanisms for urease lateral gene transfer include insertion sequence-mediated movement (Park et al. 2000) or movement by plasmid transfer. Plasmid borne ureases have been previously described for at least 2 species, Clostridium perfringens (Dupuy et al. 1997) and Escherichia coli (D'Orazio and Collins 1993b).

To further investigate the possibility that some ure $\mathrm{C}$ genes have been laterally transferred, we examined ure $\mathrm{C}$ gene $\mathrm{GC}$ content and indel patterns (nucleotide insertion-deletion) within the ure $\mathrm{C}$ gene alignment. ure $\mathrm{C}$ genes from genome-sequencing projects were examined and their GC content was compared to the GC content of their respective genomes (data not shown). No obvious discrepancies in GC content between genes and genomes were observed. The ure $\mathrm{C}$ gene alignment displayed patterns of indels that did, however, support the conclusions drawn from the phylogenetic analysis. An indel 9nt long was observed in the ure $\mathrm{C}$ sequences from the divisions Firmicutes and Actinobacillus, in addition to the 10 proteobacterial sequences that grouped within the Firmicutes and Actinobacillus. This indel was not observed in any other sequences examined in this analysis (data not shown).

Although the ureC full-length sequence phylogeny demonstrated an inexact adherence to the 16S rRNA-based phylogeny, some information regarding phylogenetic affiliation of ure $\mathrm{C}$ genes is available. For example, ure $\mathrm{C}$ sequences from taxa belonging to the $\alpha-, \beta$-, and $\gamma$-Proteobacteria formed distinct clades with high bootstrap support in the upper portion of the tree.

Therefore, it was of interest to determine how the groundwater isolates' partial ure $\mathrm{C}$ sequences would group among the other ure $\mathrm{C}$ sequences and whether or not they formed close phylogenetic associations with these taxa. A second analysis of ure $\mathrm{C}$ sequences was repeated as described here, except that cropped sequences about $\sim 137$ amino acids long were used. This sequence fragment represents the size and location of PCR amplicons theoretically generated by primers $\mathrm{L} 2 \mathrm{~F} / \mathrm{L} 2 \mathrm{R}$. The general topography of the cropped-sequence tree remained the same as the full-sequence tree; however, bootstrap support for the major nodes decreased (data not shown). A significant branch rearrangement was observed involving 7 proteobacterial sequences that formed the poorly supported clade $(57 \%)$ in the predominantly Gram-positive part of the full-length sequence phylogeny (Figure 2). In the cropped sequence analysis, these 7 taxa moved up to the predominantly proteobacterial part of the tree. The other 10 proteobacterial sequences remained intermingled with the Gram-positive taxa as seen in Figure 2.

In a third iteration of the ure $\mathrm{C}$ phylogenetic analysis, eight $\mathrm{PCR}$-amplified ure $\mathrm{C}$ sequences from groundwater isolates were added (Figure 3). The topography of this tree was essentially the same as the cropped sequence tree without isolate sequences. ure $\mathrm{C}$ cropped sequences from isolates $\mathrm{PC}, \mathrm{BC}, \mathrm{T} 02-1, \mathrm{R} 02-4$, and $\mathrm{T} 03-2 \mathrm{~A}$ grouped with $u r e \mathrm{C}$ sequences from closely related taxa in clades with bootstrap support ranging from 65 to $76 \%$. Isolates T11-6, R03-1, and R12-10, belonging to the genera Arthrobacter, Hydrogenophaga, and Acidovorax, respectively (Figure 1), did not form statistically relevant groupings with other known ure $\mathrm{C}$ sequences, primarily because the tree did not contain previously described ure $\mathrm{C}$ sequences for these genera. Most importantly, none of the isolate sequences appear to be significantly related to ure $\mathrm{C}$ sequences that were apparently obtained through a gene transfer event as described here (Figure 2).

It was concluded that the ure $\mathrm{C}$-based phylogeny for the bacterial species used in this study displays partial congruence to the universal $16 \mathrm{~S}$ rRNA-based phylogeny for bacteria. Similar conclusions were drawn from comparative phylogenetic analyses of 16S rRNA and other bacterial functional genes such as the dissimilatory sulfite reductase (Klein et al. 2001), adenosine-5' phosphosulfate reductase (Friedrich 2002), ammonia monooxygenase (Aakra et al. 2001), and nitrate and nitrous oxide reductases (Delorme et al. 2003). Partial congruence with the $16 \mathrm{~S}$ rRNA phylogeny was observed in these comparative studies; 


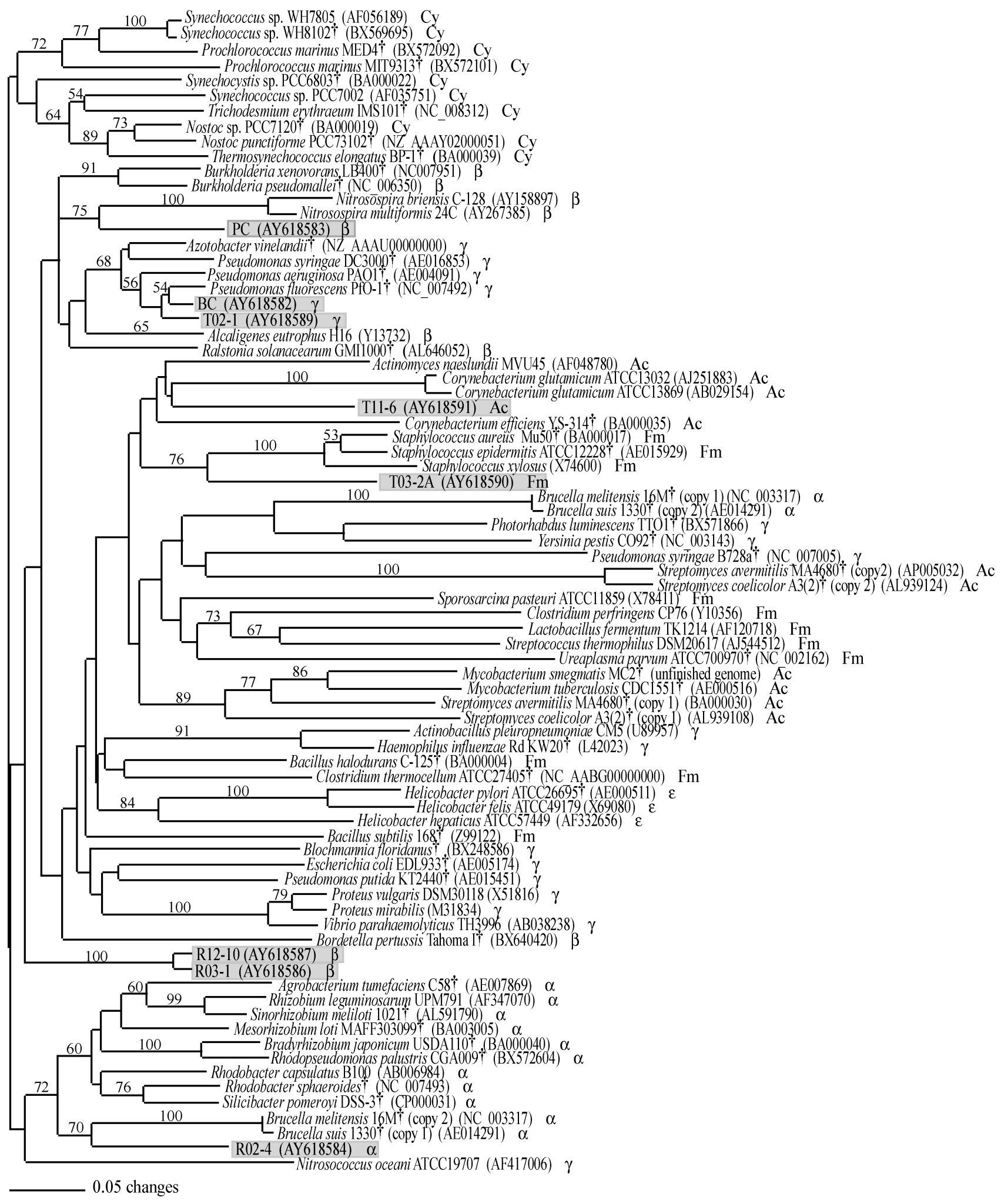

FIG. 3. Phylogeny of ureC gene sequences translated and aligned with respect to codon positions. Gray boxes indicate groundwater isolates; all others are previously described $u r e \mathrm{C}$ sequences from the GenBank database (accession numbers are given parenthetically). Phylogenetic relationships were estimated using PAUP, as described in Figure 1. All sequences were cropped to match the approximate length and location of ure C PCR amplicons generated with the L2F/L2R primer pair ( $\sim 390$ bases; 130 amino acids). Abbreviations to the right of taxa labels are as described in Figure 2. Numbers at nodes are as described in Figure 1. $\dagger$ indicates putative $u r e \mathrm{C}$ sequences identified by genome sequencing projects. Scale bar indicates $5 \%$ amino acid substitutions. 
however, evidence for lateral transfers among these genes was revealed as well. Initially, evidence for frequent lateral transfers of genes encoding essential metabolic enzymes was unexpected (Klein et al. 2001); however, there is mounting evidence that lateral gene transfer is a powerful force in the process of prokaryotic evolution, and far more genes are subject to lateral transfer than previously thought (Lawrence 1999; Garcia-Vallve et al. 2000).

Although $u r e C$ gene sequences are not robust phylogenetic markers for bacteria, the data presented here suggest that environmental $\operatorname{ureC}$ sequence data obtained with the L2F/L2R primers can provide other useful information about ureolytic populations. For example, environmental ureC PCR amplicons could be analyzed using denaturing gradient gel electrophoresis (DGGE) to examine population and diversity changes over time or in response to variable environmental conditions, such as urea amendment during a field remediation procedure. In addition, these primers can be used in quantitative-PCR or reversetranscriptase-PCR to quantify urease gene copy or expression rates in environmental samples. Despite the incongruency of ure $\mathrm{C}$ with $16 \mathrm{~S}$ rRNA genes, analysis of ure $\mathrm{C}$ gene sequences provides a snapshot of diversity with respect to a relevant functional gene rather than overall community diversity, as is observed with $16 \mathrm{~S}$ rDNA analyses.

PCR-based molecular analytical techniques were evaluated in this study for their ability to convey meaningful information about microbial community structure with respect to a specific enzymatic function. While conclusions drawn from such analyses should be cautionary, these methods are important for broadening our ability to assess microbial communities beyond the 16S rRNA gene so that we may begin to understand the contribution of community members in regards to a specific enzymatic activity. Though often less robust than 16S rRNA analysis, phylogenetic assessment of functional genes is particularly important when the functional gene of interest is not tightly associated with a distinct phylogenetic group. It is important to recognize that the methods and experimental approach described in this study can be adapted to predictive models for other functional genes.

This study demonstrated that the degenerate primer pair L2F/L2R successfully targeted ure $\mathrm{C}$ genes in diverse bacterial species, particularly those isolated from groundwater environments, and detected novel putative ure $\mathrm{C}$ sequences from groundwater isolates in the genera Hydrogenophaga, Acidovorax, Janthinobacterium, and Arthrobacter. The degeneracy of primers $\mathrm{L} 2 \mathrm{~F} / \mathrm{L} 2 \mathrm{R}$ allowed for broader detection of bacterial isolates than previously described $u r e \mathrm{C}$-specific primers, while maintaining high amplification fidelity. These primers enable investigations of a wide range of ureolytic bacterial species and exploration of their relative diversity in the environment. The novel ure $\mathrm{C}$-targeted degenerate $\mathrm{PCR}$ primers were useful in verifying the presence of native urease genetic potential in the groundwater environment, and provide a framework for future molecular studies concerning the response of the ureolytic bacterial community to in situ bioremediation strategies.

\section{REFERENCES}

Aakra Å, Utåker JB, Nes IF. 2001. Comparative phylogeny of the ammonia monooxygenase subunit A and 16S rRNA genes of ammonia-oxidizing bacteria. FEMS Microbiol Lett 205:237-242.

Altschul SF, Gish W, Miller W, Myers EW, Lipman DJ. 1990. Basic local alignment search tool. J Mol Biol 215:403-410.

Burne RA, Chen Y-YM. 2000. Bacterial ureases in infectious diseases. Microbes Infect 2:533-542.

Collier JL, Brahamsha B, Palenik B. 1999. The marine cyanobacterium Synechococcus sp. WH7805 requires urease (urea amidohydrolase, EC 3.5.1.5) to utilize urea as a nitrogen source: Molecular-genetic and biochemical analysis of the enzyme. Microbiology 145:447-459.

D'Orazio SEF, Collins CM. 1993a. The plasmid-encoded urease gene cluster of the family Enterobacteriaceae is positively regulated by UreR, a member of the AraC family of transcriptional activators. J Bacteriol 175:34593467.

D'Orazio SEF, Collins CM. 1993b. Characterization of a plasmid-encoded urease gene cluster found in members of the family Enterobacteriaceae. J Bacteriol 175:1860-1864.

Delorme S, Philippot L, Edel-Hermann V, Deulvot C, Mougel C, Lemanceau P. 2003. Comparative genetic diversity of the nar G, nosZ, and 16S rRNA genes in fluorescent pseudomonads. Appl Environ Microbiol 69:10041012.

Dupuy B, Daube G, Popoff MR, Cole ST. 1997 Clostridium perfringens urease genes are plasmid borne. Infect Immun 65:2313-2320.

Friedrich MW. 2002. Phylogenetic analysis reveals multiple lateral transfers of adenosine- $5^{\prime}$-phosphosulfate reductase genes among sulfate-reducing microorganisms. J Bacteriol 184:278-289.

Fujita Y, Ferris FG, Lawson RD, Colwell FS, Smith RW. 2000. Calcium carbonate precipitation by ureolytic subsurface bacteria. Geomicrobiol J 17:305318.

Fujita Y, Ingram JA, Cortez MM, Redden GD, Ferris FG, Smith RW. 2004. Strontium incorporation into calcite generated by bacterial ureolysis. Geochim Cosmochim Acta 68:3261-3270.

Garcia-Vallve S, Romeu A, Palau J. 2000. Horizontal gene transfer in bacterial and archaeal complete genomes. Genome Res 10:1719-1725.

Kanamori T, Kanou N, Atomi H, Imanaka T. 2004. Enzymatic characterization of a Prokaryotic urea carboxylase. J Bacteriol 186:2532-2539.

Klein M, Friedrich M, Roger AJ, Hugenholtz P, Fishbain S, Abicht H, Blackall LL, Stahl DA. 2001. Multiple lateral transfers of dissimilatory sulfite reductase genes between major lineages of sulfate-reducing prokaryotes. J Bacteriol 183:6028-6035.

Knobel LL, Bartholomay RC, Cecil LD, Tucker BJ, Wegner SJ. 1992. Chemical constituents in the dissolved and suspended fractions of ground water from selected sites, Idaho National Engineering Laboratory and vicinity, Idaho, 1989. Idaho Falls, U.S. Geological Survey. Report no. 92-51.

Koper TE, El-Sheikh AF, Norton JM, Klotz MG. 2004. Urease-encoding genes in ammonia-oxidizing bacteria. Appl Environ Microbiol 70:2342-2348.

Lawrence JG. 1999. Gene transfer, speciation, and the evolution of bacterial genomes. Curr Opin Microbiol 2:519-523.

Link PK, Mink LL. 2002. Geology, hydrogeology, and environmental remediation: Idaho National Engineering and Environmental Laboratory, Eastern Snake River Plain, Idaho, vol. Special Paper 353. Boulder, CO: Geological Society of America.

Mobley HTL, Island MD, Hausinger RP. 1995. Molecular biology of microbial ureases. Microbiol Rev 59:451-480.

Morou-Bermudez E, Burne RA. 1999. Genetic and physiologic characterization of urease of Actinomyces naeslundii. Infect Immun 67:504-512.

Pace NR, Stahl DL, Lane DJ, Olsen GJ. 1986. The analysis of natural microbial populations by ribosomal RNA sequences. In: Marshall KC, editor. Advances in Microbial Ecology, New York: Plenum. p 1-55.

Park K-S, Iida T, Yamaichi Y, Oyagi T, Yamamoto K, Honda T. 2000. Genetic characterization of DNA region containing the trh and ure genes of Vibrio parahaemolyticus. Infect Immun 68:5742-5748. 
Reasoner DJ, Geldreich EE. 1985. A new medium for the enumeration and subculture of bacteria from potable water. Appl Environ Microbiol 49:1-7.

Reed KE. 2001. Restriction enzyme mapping of bacterial urease genes: using degenerate primers to expand experimental outcomes. Biochem Mol Biol Educ 29:239-244.

Riley RG, Zachara JM, Wobber FJ. 1992. Chemical contaminants on DOE lands and selection of contaminant mixtures for subsurface science research. Washington, DC: U.S. Department of Energy Research Subsurface Science Program. DOE/ER-0547T.
Versalovic J, Koeuth T, Lupski JR. 1991. Distribution of repetitive DNA sequences in eubacteria and application to fingerprinting of bacterial genomes. Nucleic Acids Res 19:6823-6831.

Warren LA, Maurice PA, Parmar N, Ferris FG. 2001. Microbially mediated calcium carbonate precipitation: Implications for interpreting calcite precipitation for solid phase capture of inorganic contaminants. Geomicrobiol J 18:93-115.

Weisburg WG, Barns SM, Pelletier DA, Lane DJ. 1991. 16S Ribosomal DNA amplification for phylogenetic study. J Bacteriol 173: 697-703. 


\section{Appendix E:}

A preliminary assessment of the feasibility of a novel in situ remediation approach using ureolytic organisms for the immobilization of ${ }^{90} \mathrm{Sr}$ at Hanford 100-N Area.

By Y. Fujita, J.T. Taylor, L. Petzke, M. Taylor, D. Reed and R.W. Smith

In preparation for submission to a peer-reviewed journal 


\title{
A preliminary assessment of the feasibility of a novel in situ remediation approach using ureolytic organisms for the immobilization of ${ }^{90} \mathrm{Sr}$ at Hanford 100-N Area
}

\author{
Yoshiko Fujita, Joanna Taylor, Lynn Petzke, Matthew Taylor, David Reed and \\ Robert W. Smith
}

\section{Introduction}

The 100-N Area on the U. S. Department of Energy's Hanford Reservation in Washington is the site of nine former plutonium production reactors; eight were shutdown in 1971 and the last one in 1987. Disposal of the cooling water into unlined trenches and cribs has resulted in extensive vadose zone and groundwater contamination by many contaminants including ${ }^{90} \mathrm{Sr},{ }^{137} \mathrm{Cs}$, and ${ }^{238} \mathrm{Pu}$ (Hartman, 2007). Currently ${ }^{90} \mathrm{Sr}$ is the primary groundwater contaminant of concern at the site with groundwater concentrations as high as $10,000 \mathrm{pCi} \mathrm{L}^{-1}$ (Hartman, 2007). Groundwater in the 100-N Area discharges into the Columbia River through several springs located along the shoreline. Aquifer tubes were used to collect groundwater next to the rivers edge, where greater than $1000 \mathrm{pCi} \mathrm{L}^{-1}{ }^{90} \mathrm{Sr}$ has been observed (Hartman, 2007). The spring water tends to have lower ${ }^{90} \mathrm{Sr}$ activity than the aquifer water collected in the tubes, but above the U.S. Environmental Protection Agency maximum contaminant level of $8 \mathrm{pCi} / \mathrm{L} .{ }^{90} \mathrm{Sr}$ is a major health concern; it can accumulate in the bone and cause bone tumors and tumors of blood-cell forming organs such as bone marrow, spleen, and liver (Strontium, 2006).

Because radionuclide and metal contaminants such as ${ }^{90} \mathrm{Sr}$ cannot be chemically destroyed, remediation approaches are limited to either extraction/removal schemes, or methods that rely on in situ stabilization. Pump and treat has been used as a remediation tool for ${ }^{90} \mathrm{Sr}$ in the $100-\mathrm{N}$ area and only 1.8 Ci has been removed from 1995 to 2006, therefore pump and treat has been discontinued because of its ineffectiveness (Hartman, 2007). The major drawback of the 100-N Area pump and treat scheme, and indeed the major drawback for many groundwater pump and treat systems, for many common contaminants, is that most of the contaminant is associated with the solid phase rather than the water phase that is extracted (Mackay, 1989). Simple mass balance calculations using distribution coefficients for site-specific Hanford materials (Serne, 1996) suggest that greater than $99 \%$ of the ${ }^{90} \mathrm{Sr}$ is sorbed to the solid phase. Because this sorbed fraction is a potential continuing source for groundwater contamination, an effective remediation strategy for ${ }^{90} \mathrm{Sr}$ should treat both the dissolved and sorbed contaminant fractions. The importance of the sorbed ${ }^{90} \mathrm{Sr}$ being released into the water phase is particularly evident with the spike in ${ }^{90} \mathrm{Sr}$ as the water table rises (Hartman, 2007).

In the wake of the discontinued pump and treat operation, in 2006 DOE contractors at the $100-\mathrm{N}$ Area commenced a pilot-scale study of a potential immobilization scheme based on precipitation of the ${ }^{90} \mathrm{Sr}$ in apatite (Hartman, 2007). The particular approach for inducing precipitation relies on microbial activity to liberate the calcium necessary for apatite formation (Moore, 2004 and 2006). In the study reported here, we evaluated another potential biogeochemical approach for in situ ${ }^{90} \mathrm{Sr}$ immobilization at the Hanford 
100-N Area site: co-precipitation in calcite, refer to the main document for a detailed description of the reaction.

This study was a preliminary assessment of the feasibility at the 100-N Area for a novel in situ remediation approach for ${ }^{90} \mathrm{Sr}$, where microbial urea hydrolysis is used to drive the precipitation of calcite and the co-precipitation of strontium in the calcite. Water quality data from the 100-N Area indicate that geochemical conditions at the site are conducive to stable calcite precipitation, and therefore groundwater and sediment samples from the site were examined to assess the urea hydrolyzing capabilities of the planktonic and attached native microbial populations. Groundwater samples from shallow wells near the Columbia River and sediment samples collected during the installation of one of the wells were characterized for ureolytic activity using culture-dependent and cultureindependent methods. The occurrence of ureolytic organisms was assessed by a quantitative PCR assay for ureolytic genes and in situ ureolytic rate estimates using a ${ }^{14} \mathrm{C}$ method.

\section{Sample Collection and Handling}

Groundwater was collected from three monitoring wells (199-N-119, $199-\mathrm{N}-120$ and 199-N-121) located on the edge of the Hanford 100-N Area, on the shore of the Columbia River, Figure 1. The 4" $(10 \mathrm{~cm})$ i.d. (stainless steel casing) wells are located approximately $9.8 \mathrm{ft}(3 \mathrm{~m})$ apart. The screened intervals for the wells are $15-22 \mathrm{ft}(199-\mathrm{N}-119), 25-$ $29 \mathrm{ft}(199-\mathrm{N}-120), 36-49 \mathrm{ft}$ (199-N121). Water levels fluctuate at this location, but at the time of sampling the water table was approximately $10 \mathrm{ft}$ below land surface. Triplicate water samples $(\sim 10 \mathrm{~L}$ each) were collected from each well and shipped in coolers with ice to the Idaho National Laboratory (INL). The samples from well 199-N-120 were received the next day, with intact ice. Due to weather-related shipping delays, samples from wells 199-N-119 and 199-N-121 were not received at the INL until 3 days after sample collection; the samples were cool to the touch but the ice was melted. All water samples were

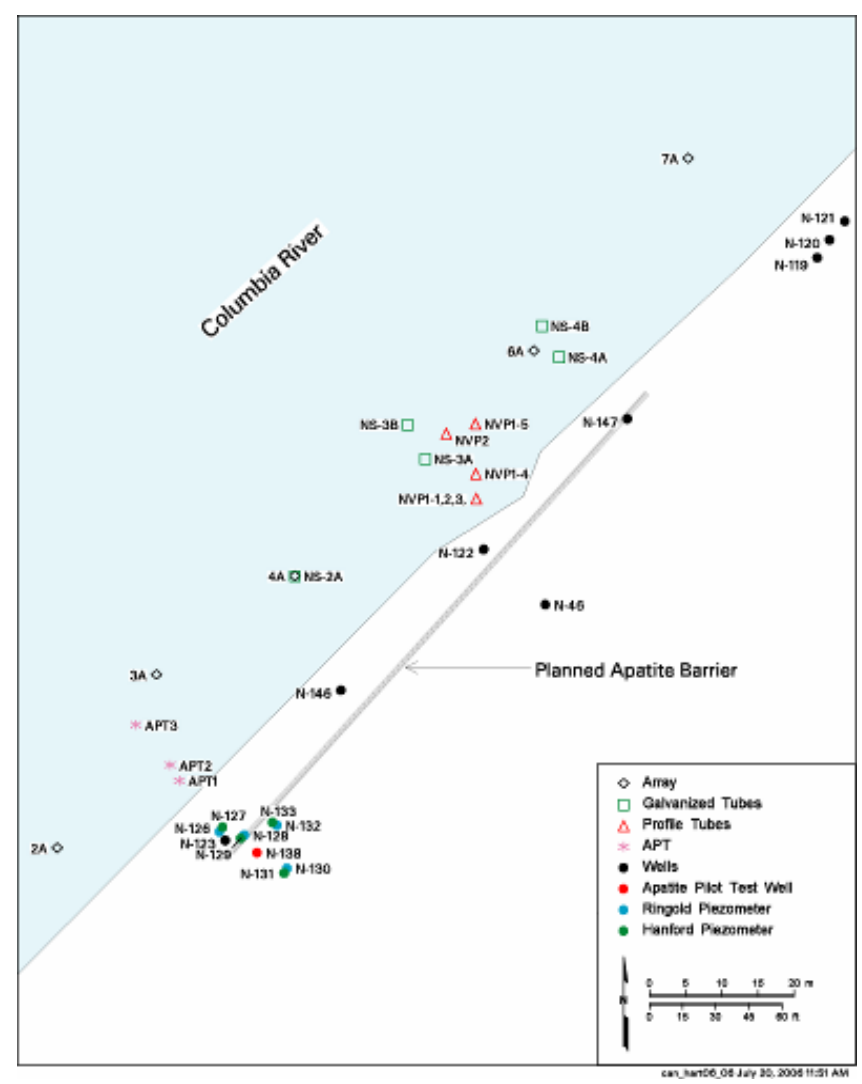

Figure 1. Groundwater samples collected from the three wells identified in the red circle (199-N-119, 199-N-120, and 199-N-121) and sediment core collected from 199$\mathrm{N}-121$ are located on the edge of Hanford 100-N Area next to Columbia River. 
processed immediately upon receipt at the INL.

Core samples were collected aseptically during the installation of well 199-N-121, and stored at $4^{\circ} \mathrm{C}$. Eleven subsamples ( $\sim 50 \mathrm{~g}$ each) were shipped overnight to the INL in ice packed coolers. The depths from which the core samples received at the INL came from are shown in Table 1. Immediately upon receipt in Idaho Falls, $1 \mathrm{~g}$ portions of sediment were preserved for cell counts by addition of $5 \mathrm{ml}$ of $3.7 \%$ formaldehyde and stored at $4^{\circ} \mathrm{C}$ until fluorescent staining and counting, which was completed within one month. Other portions of the core samples were stored at $4^{\circ} \mathrm{C}$ until processing for DNA extraction and ureolytic rate estimation. DNA extraction of the sediments was completed within one month of receipt; ureolytic rates were measured at the University of IdahoIdaho Falls within 2.5 months of receipt. Neither the core nor water samples contained ${ }^{90} \mathrm{Sr}$ at actionable levels.

Table 1. Core from Borehole 199-N-121.

\begin{tabular}{|c|c|}
\hline core $\#$ & depth (feet below land surface) \\
\hline 1 & 5 to 10 \\
\hline 2 & 10 to 10.5 \\
\hline 8 & 13 to 13.5 \\
\hline 12 & 15 to 15.5 \\
\hline 14 & 16 to 16.5 \\
\hline 17 & 17.5 to 18 \\
\hline 22 & 20 to 20.5 \\
\hline 32 & 25 to 25.5 \\
\hline 42 & 30 to 30.5 \\
\hline 52 & 35 to 35.5 \\
\hline 65 & 41.5 to 42 \\
\hline
\end{tabular}

\section{Results}

\section{DNA extraction results}

Genomic DNA from groundwater samples was visibly detectable in an agarose gel; however, genomic DNA from sediment samples was not visibly detectable.

\section{Cell enumeration}

Total cell numbers ranged between $1 \times 10^{5}$ and $4 \times 10^{6} \mathrm{~g}^{-1}$ for sediment samples (Figure 2) and 1 x $10^{5}$ and $8 \times 10^{5} \mathrm{ml}^{-1}$ for groundwater samples (Figure 3). 


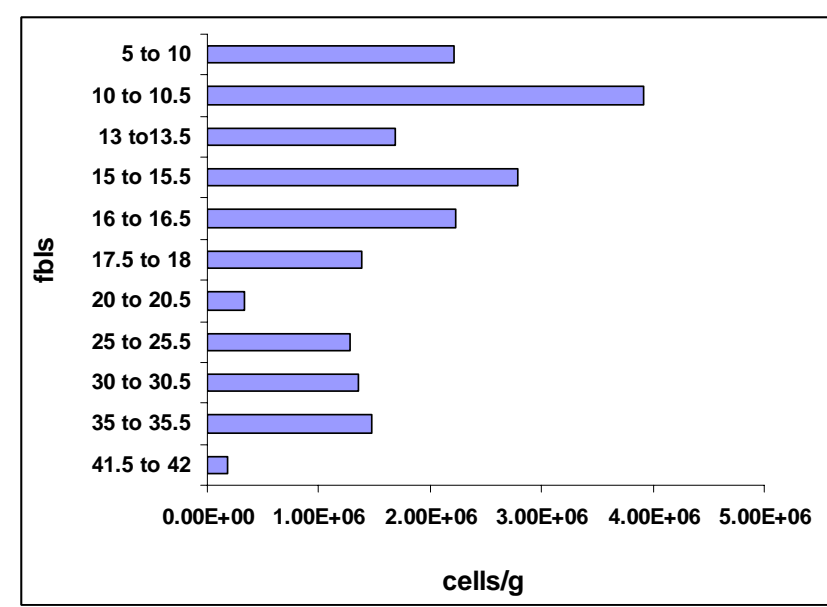

Figure 2. The total number of cells per gram of sediment collected from core 199-N-121 feet below land surface (fbls).

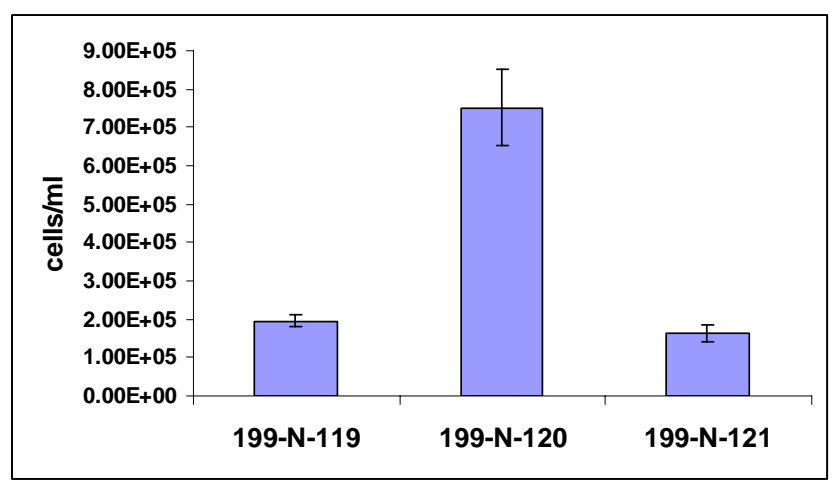

Figure 3. The total number of cells per milliliter of groundwater from wells 199-N-119, 199-N120 , and 199-N-121.

\section{MPN result}

Groundwater samples had approximately 70 ureolytic cells $\mathrm{ml}^{-1}$ in well 199-N-119, 800 ureolytic cells $\mathrm{ml}^{-1}$ in well 199-N-120, and 1,100 ureolytic cells $\mathrm{ml}^{-1} 1$ in well $199-\mathrm{N}-121$ according to the MPN estimates, refer to Figure 4. MPN estimates were not conducted for sediment samples.

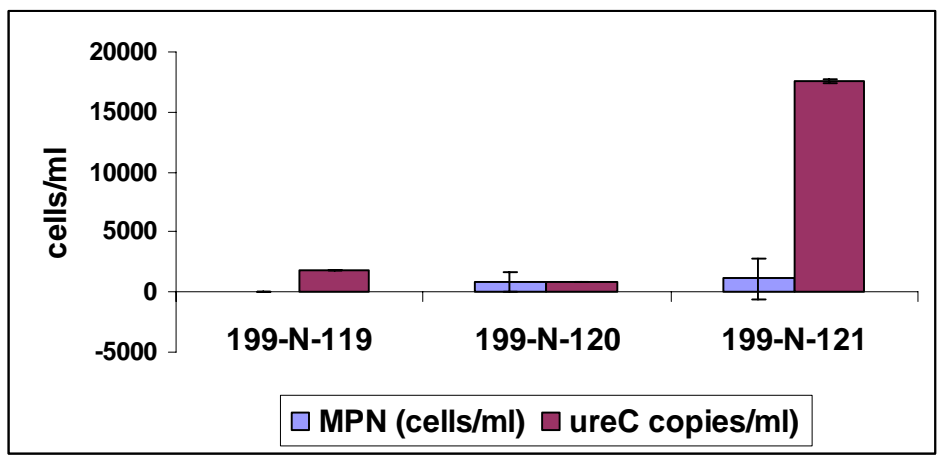

Figure 4. The number of ureolytic cells per milliliter measured by most probable number (MPN) and number of copies ureC per milliliter, error bars represent one standard deviation.

\section{Quantification of ureC Genes in Groundwater and Sediment}

The lowest $S$. pasteurii standard quantified in the assay represented 660 ureC gene copies. The reaction efficiencies were 0.82 for the groundwater sample reaction and 0.83 for the sediment sample reaction. The qPCR assay detected PCR products corresponding to 1,821 (well 199-N119), 852 (well 199-N-120), and 17,562 (well 199-N-121) ureC gene copies per ml of groundwater (Figure 4). Sediment samples obtained from the coring of the 199-N-121 well indicate that ureC genes were also present in the sediment. The qPCR assay detected PCR products corresponding to ure $\mathrm{C}$ genes in seven of the eleven core intervals with numbers ranging from roughly 374 to 124,400 copies of ureC per gram of sediment. No inhibition was detected in sediment samples that were spiked with $S$. pasteurii. 
The attached ureolytic microbial activities were measured from the sediment samples and the planktonic communities were measured in the ground water samples. Ureolytic activity was seen in all sediment samples. Core from 17.5 to $18 \mathrm{fbls}$ showed highest rates (Figure 5), consistent with the ureC quantification results (Figure 6), representing the attached ureolytic communities.

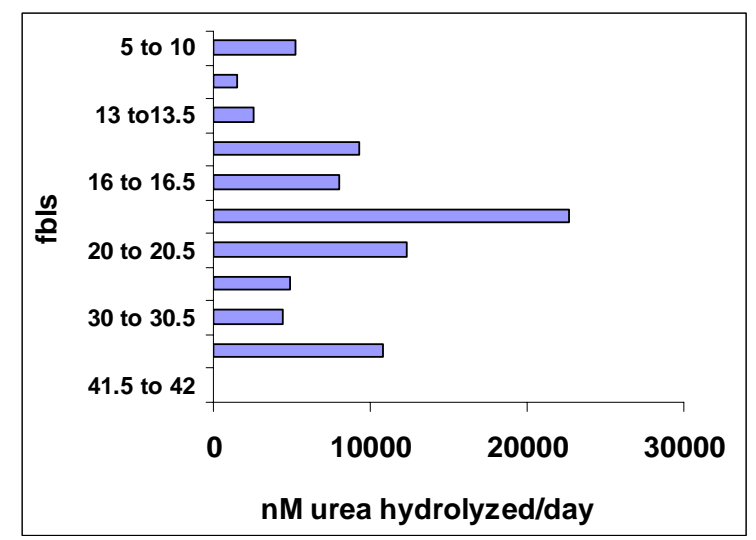

Figure 5. Ureolytic activity measured in sediments collected at different depths (feet below land surface) form core sample 199-N-121.

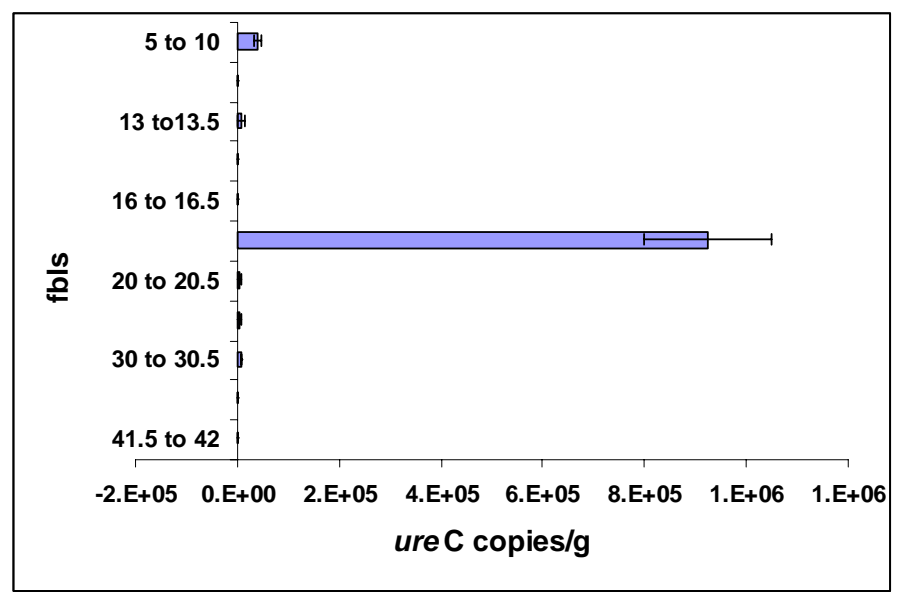

Figure 6. The number of ureC copies per gram of sediment collected from core 199-N-121 at different depth (feet below land surface, fbls), error bars represent one standard deviation.

Ureolytic activity was the highest in ground water sample for 199-N-119, representing the planktonic ureolytic communities. Ureolytic activity in samples $199-\mathrm{N}-120$ and $199-\mathrm{N}-121$ were low $(1.80 \mathrm{E}-6$ and $2.23 \mathrm{E}-3 \mathrm{nM}$ urea hydrolyzed/day), however they where above the blank (filter synthetic groundwater, no microbes; Figure 7).

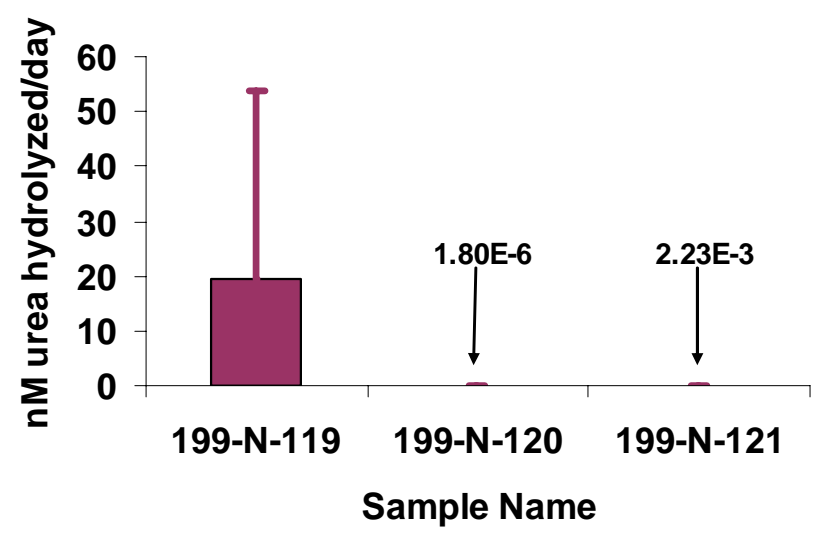

Figure 7. Ureolytic activity measured from groundwater collected from three different wells, error bars represent $95 \%$ confident interval. 


\section{Conclusions}

The intent of this research was to determine if an indigenous population of ureolytic bacteria existed at the Hanford site and could be called upon to encourage the co-precipitation of ${ }^{90} \mathrm{Sr}$ with calcite. Results from MPN estimates, qPCR assay, and in situ ureolytic rate estimates indicated that ureolytic bacteria are present in the ground water in 100-N Area at Hanford and in situ ureolytic rate estimates detected activity in all sediment samples, while the qPCR assay detected ureC genes in 6 of 11 sediment samples for core 199-N-121 in 100-N Area at Hanford. In the interval between 17.5 and 18 feet below land surface, there was a large surge in estimated ureolytic rates and ure $\mathrm{C}$ genes. In situ ureolytic rate estimates were 1000x higher for the sediment samples than the ground water samples, indicating the majority of ureolytic activity is attributed to the attached communities. Therefore, our results indicated that significant microbial ureolysis activity does occur at the 100-N Area, and that engineered calcite precipitation is a potential option for remediation.

\section{Acknowledgments}

Tyler Gilmore, Donald Mendoza, Mary Hartman, Mark Freshley at PNNL. Funding provided by Department of Energy, Environmental Management Science Program, Project Number 87016.

\section{References}

Hartman, M.J., L.F. Morasch, W.D. Webber. 2007. Hanford site groundwater monitoring for fiscal year 2006. PNNL-16346.

Mackay, D.M., J.A. Cherry. 1989. Groundwater contamination: Pump-and-treat remediation. Environmental Science and Technology. 23 (6) 630-636.

Moore, R. C., C. Sanchez, K. Holt, P.C. Zhang, H. F. Xu, G.R. Choppin. 2004. Formation of hydroxyapatite in soils using calcium citrate and sodium phosphate for control of strontium migration. Radiochimica Acta. 92 (9-11) 719-723.

Moore, R.C., J. Szecsody, M. Truex, K. Kelean, R. Bontchev, C. Ainsworth. 2006. Formation of nanosize apatite crystals in sediments for containment and stabilization of contaminants. In Nanoscale Technologies for Remediation, Burns, F., Ed. CRC Press.

Serne, R. J. V.L LeGore. 1996. Strontium-90 adsorption-desorption properties and sediment characterization at the 100 N-Area; PNL-10899,; Pacific Northwest National Laboratory,: Richland, WA.

Strontium. 2006. Argonne National Laboratory, EVS. Human Health Fact Sheet. http://www.ead.anl.gov/pub/doc/Strontium.pdf. 


\section{Appendix F:}

Testing the specificity of primers to environmental ammonia monooxygenase (AMOA) genes in groundwater treated with urea to promote calcite precipitation.

$$
\text { By Freeman, S., D.W. Reed, and Y. Fujita. }
$$

In U.S. Department of Energy Journal of Undergraduate Research. 6:114-118 (2006). 
tephanie Freeman graduated with an honors B.S. in chemical engineering $\checkmark$ from the University of Arizona in December of 2005. During the summer before her final semester she participated in the Science Undergraduate Laboratory Internships (SULI) program at Idaho National Laboratory in Idaho Falls, Idaho. Her SULI project involved investigating the use of nucleotide primers designed for the ammonia monooxygenase gene in detection of ammonia oxidizing bacteria in environmental samples. She is an incoming graduate student at Massachusetts Institute of Technology (MIT) in the MS of chemical engineering practice program and is currently completing an independent research project on perchlorate reducing bacteria at Wageningen University in The Netherlands. She will graduate in August 2007 and hopes for a PhD position afterward.

$\mathrm{D}$ avid W. Reed is a scientist in the Biological Sciences Department at the Idaho National Laboratory in Idaho Falls, Idaho. He received a B.S. in microbiology) and M.S. in zoology from Brigham Young University and a subsequent $\mathrm{PhD}$ in microbiology, molecular biology and biochemistry from the University of Idaho. He has more than twelve years of experience using molecular methods to probe environments for microbial activity and diversity, characterizing microbial enzymatic and metabolic systems, and conducting comparative proteomic and genome analysis in microbial systems. He is experienced working with anaerobes, hyperthermophiles, sulfate reducers, and industrially relevant bacteria. He is an affliate faculty member in biological sciences at Idaho State University and in environmental science at the University of Idaho. He is published in peer-reviewed journals and has given numerous presentations.

$\mathrm{Y}$ oshiko Fujita is a researcher in the Biological Sciences Department at the Idaho National Laboratory (INL) in Idaho Falls, Idaho. She received a B.A. in chemistry from Williams College, and M.S. and PhD degrees in civil and environmental engineering from Stanford University. Her primary research focus has been the characterization of microbial activity in subsurface environments using cultivation-based and molecular techniques, and examining the associated effects on contaminant fate and transport. She also has expertise in the identification of metabolic products and intermediates, and is interested in changes in organic water quality that occur during aquifer recharge with reclaimed water. Recently she has been interested in the interactions between microorganisms and minerals, and on the coupling between hydrologic transport and microbially induced mineralization in porous media.

\title{
TESTING THE SPECIFICITY OF PRIMERS TO ENVIRONMENTAL AMMONIA MONOOXYGENASE (AMOA) GENES IN GROUNDWATER TREATED WITH UREA TO PROMOTE CALCITE PRECIPITATION
}

\author{
Stephanie Freeman, David W. Reed, and Yoshiko Fujita
}

\begin{abstract}
Bacterial ammonia monooxygenase (amoA) genes in DNA isolated from microorganisms in groundwater were characterized by amplification of amoA DNA using polymerase chain reaction (PCR), Restriction Fragment Length Polymorphism (RFLP) analysis, and sequencing. The amoA gene is characteristic of ammonia oxidizing bacteria (AOB). The DNA extracts were acquired from an experiment where dilute molasses and urea were sequentially introduced into a well in the Eastern Snake River Plain Aquifer (ESRPA) in Idaho to examine whether such amendments could stimulate enhanced ureolytic activity. The hydrolysis of urea into ammonium and carbonate serves as the basis for a potential remediation technique for trace metals and radionuclide contaminants that can co-precipitate in calcite. The ammonium ion resulting from ureolysis can promote the growth of $A O B$. The goal of this work was to investigate the effectiveness of primers designed for quantitative PCR of environmental amoA genes and to evaluate the effect of the molasses and urea amendments upon the population diversity of groundwater AOB. PCR primers designed to target a portion of the $a m o A$ gene were used to amplify amoA gene sequences in the groundwater DNA extracts. Following PCR, amplified gene products were cloned and the clones were characterized by RFLP, a DNA restriction technique that can distinguish different DNA sequences, to gauge the initial diversity. Clones exhibiting unique RFLP patterns were subjected to DNA sequencing. Initial sequencing results suggest that the primers were successful at specific detection of amoA sequences and the RFLP analyses indicated that the diversity of detected amoA sequences in the ESRPA decreased with the additions of molasses and urea.
\end{abstract}

\section{INTRODUCTION}

One of the crucial steps in the nitrogen cycle is the oxidation of ammonia to nitrite. The ammonia monooxygenase (amoA) gene has been identified as an integral gene in the conversion of ammonia to hydroxylamine, the first step in overall ammonia oxidation [1]. The amoA gene codes for the catalytic subunit of the ammonia monooxygenase enzyme. The amoA gene is present in all nitrosifying bacteria that take part in this critical step of the global nitrogen cycle [2]. This gene was previously thought to be unique to bacteria, but recent research has identified ammonium oxidizing 
archaeal species that have a similar archaeal amoA gene and that may play an important role in marine nitrogen cycling [3].

Along with collaborators, Idaho National Laboratory (INL) is currently investigating a remediation technique for radioactive strontium-90 $\left({ }^{90} \mathrm{Sr}\right)$ contamination of aquifers based on the incorporation of strontium into calcite (calcium carbonate, $\mathrm{CaCO}_{3}$ ). In calcite-saturated aquifers such as the Eastern Snake River Plain Aquifer (ESRPA) in Idaho, co-precipitated strontium in calcite is expected to remain stable for hundreds of years. The specific remediation method under investigation is greatly dependent upon the acceleration of calcite precipitation by native groundwater microorganisms' hydrolysis of urea:

$$
\begin{gathered}
\mathrm{H}_{2} \mathrm{NCONH}_{2}+2 \mathrm{H}_{2} \mathrm{O} \rightarrow 2 \mathrm{NH}_{4}^{+}+\mathrm{CO}_{3}^{2-} \\
\text { (Urea + Water } \rightarrow \text { Ammonium + Carbonate) }
\end{gathered}
$$

The carbonate ion reacts with metals to form carbonate minerals, while the ammonium can serve to displace metal cations (such as $\mathrm{Ca}^{2+}$ and $\mathrm{Sr}^{2+}$ ) from ion exchange sites on aquifer solids, making them available for reaction with the carbonate. However, the ammonium could also serve as an electron donor for ammonia oxidizing bacteria $(\mathrm{AOB})$ present in the aquifer.

At INL, a quantitative Polymerase Chain Reaction (qPCR) technique is being developed to evaluate the effect of urea additions on native $\mathrm{AOB}$ populations present in groundwater. This $\mathrm{qPCR}$ method utilizes primers designed to specifically target the amoA gene in environmental microbial communities. Methods based on the presence of the amoA gene for detection and quantification of AOB species have been previously developed based on conventional Polymerase Chain Reaction (PCR) [4], competitive PCR (c-PCR) [5] and real-time PCR [6]. In this work, we used real-time PCR primers originally developed by others $[4,6]$ with slight modifications in an effort to capture more environmental amoA genes and exclude sequences for the similar pmoA gene, a subunit of the membrane bound methane monooxygenase gene (pMMO). Parts of the pmoA gene have high sequence similarity to $a m o \mathrm{~A}$ and non-specific priming is common [6].

The specific objective of the work reported here was to test the effectiveness of these primers in targeting amoA genes in environmental samples and to characterize the diversity of genes that could be detected. The primers were applied to genomic DNA extracts collected previously as part of a field experiment in the ESRPA where dilute molasses and urea were added to the aquifer in order to stimulate ureolytic activity. After amplification of genomic DNA with these primers, initial diversity was observed through the use of Restriction Fragment Length Polymorphism (RFLP) analysis. Sequencing was then performed in order to compare these environmental amoA gene sequences with amoA sequences reported by others for clones and known $\mathrm{AOB}$ species.

\section{MATERIALS AND METHODS}

Sample Origin: Genomic DNA extracts from microorganisms in groundwater samples taken during the course of a 2002 field experiment using an ESRPA well located at University Place, Idaho

\begin{tabular}{|c|c|c|c|}
\hline Primer Name & Direction & Sequence & Ref. \\
\hline A189 & Forward & 5' - GGHGACTGGGAYTTCTGG - 3' & [8] \\
\hline A189 DR & Forward & 5' - GGNGACTGGGAYTTCTGG - 3' & [9] \\
\hline amoA-2R' & Reverse & 5' - CCTCKGSAAAGCCTTCTTC - 3' & [4] \\
\hline amoA-2R' DR & Reverse & 5' - CCCCTSBGSSRAAVCCTTYYTTC - 3' & [9] \\
\hline
\end{tabular}
Falls, ID, were used as PCR templates during this study. During
Table 1. amoA primers. Primers $\mathrm{A} 189$ and amoA-2R' are shown along with the primers used in this study, A189 DR and amoA-2R' DR. Primers were designed from alignments of sequences of amoA genes from Nitrosomonas and Nitrosospira genera. Changes made to the standard amoA primers are indicated with bold and underlined typeface. Sequences, given from 5' to $3^{\prime}$ end, include degeneracies represented by $B, H, K, N, R, S, Y$, and V. B represents CGT (implying a C, G, or $T$ at that position). Similarly, $\mathrm{H}$ represents ATC, K represents GT, N represents ACGT, $R$ represents AG, S represents CG, $Y$ represents $\mathrm{CT}$, and $\mathrm{V}$ represents ACG.

the first phase of the field experiment, Pre-Treatment, groundwater samples were taken prior to the addition of experimental amendments to establish the background conditions. Dilute molasses $(0.00075 \%)$ was delivered into the well during the second phase (two weeks in duration), known as Post-Molasses, and urea (and no molasses) was added in the third and final phase (also a two week period), known as Post-Urea. Groundwater samples were collected periodically throughout the experiment and DNA was extracted from cells collected on filters (20 L filtered per extract) [7] using conventional methods. A more detailed description of the field experiment and the DNA extractions is provided in Tyler (2004) [7].

amoA Gene Specific Primers: Primers A189 DR and amoA2R' DR were used for the PCR amplification (Table 1). The primers were based on primers A189 and amoA-2R' developed in previous studies $[4,8]$. Primer A189 DR targets both bacterial amoA and pmoA genes while the amoA-2R' DR primer is designed to target the amoA gene only, excluding the amoA gene present in Nitrosococcus species [9].

PCR Amplification: The optimized PCR reaction mixture consisted of Taq2000 Polymerase (1U, Stratagene, La Jolla, California, USA), 1X Taq2000 buffer, dNTPs $(0.2 \mathrm{mM}$; Roche Applied Science, Indianapolis, Indiana, USA), BSA $(0.2 \mu \mathrm{g} / \mathrm{mL}$; Roche Applied Science), A189 DR forward primer (900 nM), amoA-2R' DR reverse primer $(300 \mathrm{nM})$, and DNA template $(2 \mu \mathrm{L})$. Genomic DNA from Nitrosomonas europaea was used as template for a positive control reaction. Multiple negative reactions used either no added genomic DNA (water) or genomic DNA extracts from Escherichia coli and Methylococcus capsulatus. The reactions were performed on a GeneAmp PCR System 9700 thermocycler (Applied Biosystems, Foster City, California, USA) using the following thermal program: $94^{\circ} \mathrm{C}(4 \mathrm{mins})$, then 38 cycles of $94^{\circ} \mathrm{C}$ ( 45 secs), $57^{\circ} \mathrm{C}(60$ secs $)$, and $72^{\circ} \mathrm{C}(60$ secs $)$, with a final hold of $72^{\circ} \mathrm{C}$ (5 minutes). PCR products were verified for correct size (670bp) and purity by electrophoresis on an ethidium bromide stained $1.3 \%$ agarose gel.

Cloning: Prior to cloning, PCR products derived from multiple samples taken from each of the three phases of the field experiment were pooled (five products for Pre-Treatment, three products from Post-Molasses, and two products for Post-Urea) and then purified by affinity column and gel purification (Qiagen PCR Purificaiton 
and Q1Aquick Gel Extraction Kits; Qiagen, Valencia, California, USA). Cloning reactions were performed using the $\mathrm{TOPO}^{\circ} \mathrm{TA}$ Cloning system (Invitrogen, Carlsbad, California, USA) following the manufacturer's directions. Cloning reactions were performed on the pooled PCR products from the three different phases, as well as a positive control (N. europaea) and a negative control (only the reaction with no DNA template), resulting in the generation of 5 separate clone libraries. PCR products were ligated and added to 50 $\mu \mathrm{L}$ of One Shot ${ }^{\oplus}$ TOP10 Escherichia coli competent cells (Invitrogen, Carlsbad, California, USA) for transformation. The transformed cells were plated on LB agar plates containing S-Gal, ITPG, and kanamycin $(50 \mu \mathrm{g} / \mathrm{mL}$; Sigma-Aldrich Corp., St. Louis, Missouri, USA), and grown overnight at $37^{\circ} \mathrm{C}$. For each treatment phase clone library, 50 colonies were transferred to new LB agar kanamycin plates, grown overnight, and stored for further analysis.

Restriction Fragment Length Polymorphism (RFLP): Clones from each library were analyzed using RFLP. Individual colonies from each library were re-suspended in $10 \mu \mathrm{L}$ of sterile water and lysed for 10 mins at $99^{\circ} \mathrm{C}$. The lysed cells' DNA was used as template for PCR as described previously, after which the PCR product $(20 \mu \mathrm{L})$ was used for the restriction analysis. The restriction reaction also contained enzymes HinP1 and MsPI (0.4 U each; New England Biolabs, Ipswich, Massachusetts, USA) in 1X NEBuffer 2, and Triton X-100 (1\%; Promega, Madison, Wisconsin, USA). The restriction mixture was incubated at $37^{\circ} \mathrm{C}$ for 4.5 hours. RFLP products were analyzed by electrophoresis on a $3 \%$ MetaPhor ${ }^{\circ}$ agarose (Cambrex, East Rutherford, New Jersey, USA) gel and stained with ethidium bromide.

Plasmid Purification and Sequencing: After RFLP analysis, plasmid purification was performed on the clones selected for sequencing. Plasmids were extracted from the E. coli cells using the QIAprep Spin Miniprep Kit (Qiagen, Valencia, California, USA) according to manufacturer's instructions. Each purified plasmid (50-100 ng) was subjected to cycle sequencing (10 $\mu \mathrm{L}$ reaction) with $2 \mu \mathrm{L} 2.5 \mathrm{X}$ sequencing buffer and $1 \mu \mathrm{L}$ BigDye, both part of the BigDye ${ }^{\circ}$ Terminator Cycle Sequencing Kit (Applied Biosystems, Foster City, California, USA), and $1 \mu \mathrm{L}$ primer (T7, M13F, and M13R; Operon Technologies, Huntsville, Alabama, USA). The

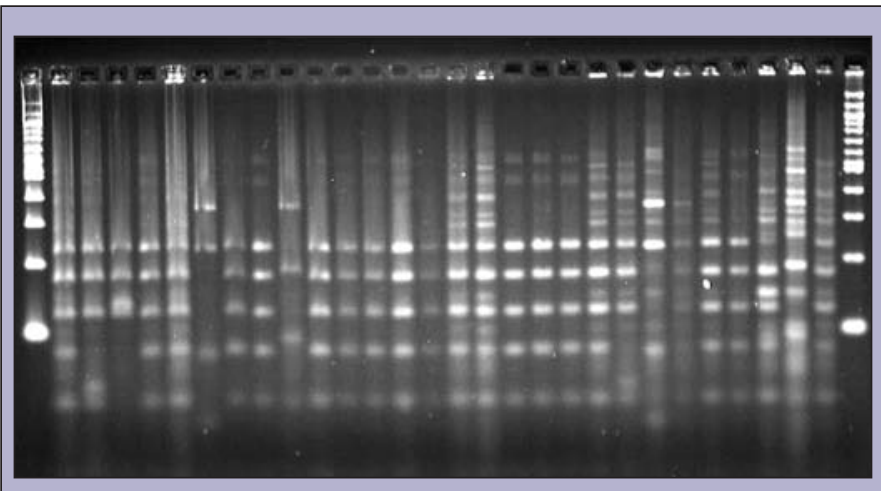

Figure 1. Example of an RFLP gel from Pre-treatment groundwater sample. The outer lanes contain $100 \mathrm{bp}$ DNA ladder (New England Biolabs, Ipswich, Massachusetts, USA) while the inner 28 lanes contain clones from the Pre-treatment groundwater sample. Samples were digested with HinP1 and MsP1 restriction enzymes and were electrophoresed on a $3 \%$ agarose gel and stained with ethidium bromide. sequencing reaction products were purified using a MultiScreen ${ }_{384^{-}}$ SEQ filter plate (Millipore, Billerica, Massachusetts, USA). The reactions were subsequently washed with $0.3 \mathrm{mM}$ EDTA, $\mathrm{pH}$ 7.8 and re-suspended in $0.3 \mathrm{mM}$ EDTA, $\mathrm{pH}$ 7.8. Sequencing was performed in an ABI Prism Model 3700 sequencer (Applied Biosystems, Foster City, California, USA).

\section{RESULTS}

The diversity of the amoA sequences detected in the UP-1 groundwater samples was characterized using RFLP. The RFLP gels (see for example Figure 1) were analyzed visually to identify unique banding patterns. Initially, PCR products with a common RFLP banding pattern within each library were assigned to the same RFLP group (A through BB; Table 3). Then, patterns were compared between the libraries to see if similar RFLP patterns were found in more than one clone library. In this way, some patterns were found in multiple libraries and resulted in more than one RFLP group label. RFLP analysis of the Pre-Treatment clones showed 12 unique banding patterns from the 50 clones of that library whereas RFLP analysis of the second library, Post-Molasses, and the third library, Post-Urea, showed 8 and 7 unique banding patterns respectively. Two unique banding patterns, namely RFLP Groups $\mathrm{A} / \mathrm{J}_{1}-\mathrm{J}_{2} / \mathrm{Q}$

\begin{tabular}{|ccc|}
\hline Primer Name & Direction & Sequence \\
\hline T7 & Forward & 5' - TAATACGACTCACTATAGGG - 3' \\
M13F (-20) & Forward & 5' - GTAAAACGACGGCCAG - 3' \\
M13R & Reverse & 5' - CAGGAAACAGCTATGAC - 3' \\
\hline
\end{tabular}

Table 2. Primers used in sequencing reaction. The oligonucleotide sequences complementing these primers are all found on the TOPO TA vector used during cloning. A majority of the clones chosen for sequencing after RFLP were sequenced with at least two of the primers listed above.

and $C / L / R$, were found in all three samples. This may indicate that the bacterial species represented in these patterns were present throughout the course of the UP-1 experiment. There was also one common pattern found in the Pre-Treatment and Post-Molasses libraries, RFLP Groups G/P, and one pattern present in only the Pre-Treatment and Post-Urea libraries, RFLP Groups E/V. All other banding patterns from each library appeared to be unique.

Sequencing was performed on unique RFLP clones and the clones derived from the PCR control reactions. The positive control reaction used a $N$. europaea genomic DNA template while the negative control reaction used no added DNA template in the initial PCR reaction. All of the clones were sequenced using at least two of the three sequencing primers (Table 2) and the majority of clone sequences were visually analyzed to confirm the accuracy of the automatically generated sequence produced by the sequencing software. The sequences were manually fitted if necessary and both the primer sites and vector nucleotides were removed. Since multiple sequences were obtained for each clone, a consensus sequence was generated for each clone. Consensus sequences were compared to the NCBI (National Center of Biotechnology Information) database 


\begin{tabular}{|c|c|c|c|c|}
\hline \multirow{2}{*}{$\begin{array}{l}\text { RFLP } \\
\text { Group }\end{array}$} & \multirow{2}{*}{$\begin{array}{c}\text { Common } \\
\text { RFLP } \\
\text { Patterns }\end{array}$} & \multicolumn{3}{|c|}{ Number of clones assigned to each RFLP Group } \\
\hline & & $\begin{array}{c}\text { Pre- } \\
\text { Treatment }\end{array}$ & Post-Molasses & Post-Urea \\
\hline A & \multirow{2}{*}{$\mathrm{J}_{1}-\mathrm{J}_{2}, \mathrm{Q}$} & 32 & 35 & 41 \\
\hline B & & 2 & 0 & 0 \\
\hline C & \multirow[t]{2}{*}{$L, R$} & 1 & 7 & 4 \\
\hline D & & 2 & 0 & 0 \\
\hline E & \multirow[t]{2}{*}{ V } & 2 & 0 & 1 \\
\hline $\mathrm{F}_{1}-\mathrm{F}_{2}$ & & 3 & 0 & 0 \\
\hline G & \multirow[t]{3}{*}{$P$} & 1 & 1 & 0 \\
\hline H & & 1 & 0 & 0 \\
\hline I & & 1 & 0 & 0 \\
\hline K & \multirow[t]{12}{*}{0} & 0 & 2 & 0 \\
\hline M & & 0 & 1 & 0 \\
\hline $\mathrm{N}$ & & 0 & 1 & 0 \\
\hline$S$ & & 0 & 0 & 1 \\
\hline $\mathrm{T}$ & & 0 & 0 & 1 \\
\hline U & & 0 & 0 & 1 \\
\hline W & & 1 & 0 & 0 \\
\hline$x$ & & 1 & 0 & 0 \\
\hline$Y$ & & 1 & 0 & 0 \\
\hline Z & & 0 & 1 & 0 \\
\hline AA & & 0 & 1 & 0 \\
\hline $\mathrm{BB}$ & & 0 & 0 & 1 \\
\hline \multicolumn{2}{|c|}{$\begin{array}{l}\text { Number of Unique } \\
\text { RFLP Patterns }\end{array}$} & 12 & 8 & 7 \\
\hline \multicolumn{5}{|c|}{$\begin{array}{l}\text { Table 3. Comparison of RFLP groups found after cloning UP-1 } \\
\text { groundwater samples. The three UP-1 clone libraries, Pre-Treatment, } \\
\text { Post-Molasses, and Post-Urea all had varying numbers of unique RFLP } \\
\text { banding patterns, decreasing in number from Pre-Treatment to Post- } \\
\text { Urea. The Common RFLP Patterns column indicates the RFLP patterns } \\
\text { that are common between different clone libraries. RFLP groups were } \\
\text { first assigned for each library and then compared between the different } \\
\text { libraries, resulting in multiple labels in some instances. }\end{array}$} \\
\hline
\end{tabular}

using BLAST (Basic Local Alignment Search Tool) [10] to observe how the sequences obtained were related to known amoA gene sequences.

As expected, BLAST analysis of the gene sequences obtained for the positive controls (clones Pos 1 and Pos2) indicated a very close relationship to $N$. europaea (complete genome, NCBI ascension number |BX321863.1|). Although only a very faint band of DNA was visualized in the ethidium bromide gel from the negative control sample, the DNA was cloned (clones Neg1 and Neg2), and the sequences closely matched a portion of the $N$. europaea genome, indicating that contamination of the negative control from the positive control might have occurred during PCR amplification. For the clones derived from environmental samples, data was not obtained for 5 groups (RFLP pattern A, L, S, T, and X clones) because of inefficient sequencing reactions that produced unreadable outputs. The remaining 25 clones were submitted to BLAST for analysis. A majority of the sequenced clones, 14 in total (representing RFLP groups B, C, F1, F2, G, I, J1, J2, N, P, Q, R, Z, and BB), matched most closely to the amoA gene from two unidentified bacteria (isolate E-207M, NCBI ascension number |AJ317947| and clone W10 6827 (DQ008439|). With respect to known isolated bacteria, the output from the BLAST search indicated that the sequence from the clones matched most closely to the amoA gene of Nitrosomonas sp. AL212 (NCBI ascension number |AF327918|).
Three additional clones were very similar to those obtained for the positive control. The BLAST analysis of these clones $\mathrm{E}, \mathrm{H}$, and $\mathrm{V}$ indicated that the highest similarity was to the amoA gene region of $N$. europaea,. The remaining 8 clone sequences $(\mathrm{D}, \mathrm{K}, \mathrm{M}, \mathrm{O}$, U, W, Y, and AA) were similar in size to the expected amoA PCR products yet the sequencing suggested improper priming during the sequencing reaction.

\section{DISCUSSION AND CONCLUSIONS}

Analysis of the RFLP screening results showed differences between the banding patterns of the clones obtained from the three UP-1 experimental treatment phases. The RFLP diversity of the amoA gene fragments apparently decreased over the course of the experiment with the first experimental period, Pre-Treatment, having the greatest number of unique banding patterns. It is possible that some species might have been more responsive than others in this changing environment and dominated the AOB community during the different phases of the experiment. Only two banding patterns were common in all three clone libraries, while only two other patterns were found in multiple clone libraries. The other banding patterns were unique to the sample library in which each was found. As a majority of the banding patterns were changing with each sample, with only a few being maintained throughout the various samples, the RFLP analysis seems to indicate that the molasses and urea amendments have a large impact on the subsurface microbiological community.

Sequence data for three of the four RFLP groups with the most common RFLP pattern $\left(\mathrm{J}_{1}, \mathrm{~J}_{2}\right.$, and Q; unfortunately the sequencing reaction for the clone representing group A did not provide a usable sequence) matched closely with the sequence of the amoA gene of known AOB species. Additionally, clones that represented eleven other RFLP banding patterns indicated a close match with this same, known $\mathrm{AOB}$ species. Because a majority of the clone sequences were found to closely match known AOB species, it appears that our primers successfully detected bacterial amoA genes in the environment. The fact that at least 14 clones shared a similar BLAST output suggests that one particular species or closely related AOB may dominate the nitrosifying subsurface microbial community of the ESRPA. However, potential biases in DNA extraction, PCR, and cloning mandate caution in extrapolating results from clone libraries to the extant microbial communities [11].

The correlation of the gene sequences of RFLP groups $\mathrm{E}, \mathrm{H}$, and $V$ to that of $N$. europaea and the finding of this same sequence in the negative control suggested that contamination might have occurred during PCR. Another possibility is that the subsurface community in the ESRP aquifer did in fact naturally contain $N$. europaea or closely related organisms.

In summary, preliminary sequencing results indicate that the primers used in this study were selective for the amoA gene region of various AOB. This finding supports the use of these primers to gauge the effect of urea addition on both the quantity and composition of the AOB community of the subsurface. However, further work is needed to elucidate the relationships between the gene sequences obtained here and the amoA gene sequences of known AOB species. 


\section{ACKNOWLEDGEMENTS}

This work was conducted at the Idaho National Laboratory in Idaho Falls, Idaho, USA. I would especially like to thank the Department of Energy and the SULI program for allowing me the opportunity to complete this work and gain valuable research experience. Special thanks go to Dr. David Reed for his instruction and assistance during every step of my project. Also, I would like to acknowledge Dr. Yoshiko Fujita, my mentor, who offered valuable advice throughout the project and Lynn Petzke for her technical assistance and Tina Tyler for DNA samples.

\section{REFERENCES}

[1] T. C. Hollocher, M. E. Tate, and D. J. D. Nicholas, "Oxidation of ammonia by Nitrosomonas europea: definitive 180tracer evidence that hydroxylamine formation involves a monooxygenase," in The Journal of Biological Chemistry, Vol. 256, No. 21, pp. 10834-10836, Nov. 1981.

[2] C. D. Sinigalliano, D. N. Kuhn, and R. D. Jones, "Amplification of the amoA Gene from Diverse Species of Ammonium-Oxidizing Bacteria and from an Indigenous Bacterial Population from Seawater," in Applied Environmental Microbiology, Vol. 61, No. 7, pp. 2702-2706, July 1995.

[3] C. A. Francis, K. J. Roberts, J. M. Bemen, A. E. Santoro, and B. B. Oakley, "Ubiquity and Diversity of Ammonia-oxidizing Archaea in Water Columns and Sediments of the Ocean," in PNAS, Vol. 102, No. 41, pp. 14683-14688.

[4] J. H. Rotthauwe, K. P. Witzel, W. Liesack, "The Ammonia Monooxygenase Structural Gene amoA as a Functional Marker: Molecular Fine-Scale Analysis of Natural Ammonia-Oxidizing Populations," in Applied Environmental Microbiology, Vol. 63, No. 12, pp. 4704-4712, Dec. 1997.

[5] G. Harms, A. C. Layton, H. M. Dionisi, I. R Gregory, V. M. Garrett, S. A. Hawkins, K. G. Robinson, and G. S. Sayler, "Real-Time PCR Quantification of Nitrifying Bacteria in a Municipal Wastewater Treatment Plant," in Environmental Science and Technology, Vol. 31, No. 2, pp. 343-351, 2003.

[6] A. J. Holmes, A. Costello, M. E. Lidstrom, and J. C. Murrell, "Evidence that particulate methane monooxygenase and ammonia monooxygenase may be evolutionarily related," in FEMS Microbiology Letters, Vol. 132, No. 3, pp. 203-208, October 1995.

[7] T. L. Tyler, "Detection and Characterization of Urease Genes in Groundwater Bacterial Communities," Ph.D. thesis, Department of Biology, Idaho State University, Pocatello, Idaho, 2004.
[8] Y. Okano, Y. R. Hristova, C. M. Leutenegger, L. E. Jackson, R. F. Denison, B. Gebreyesus, D. Lebauer, and K. M. Scow, "Application of Real-Time PCR To Study Effects of Ammonium on Population Size of Ammonia-Oxidizing Bacteria in Soil," in Applied Environmental Microbiology, Vol. 70, No 2, pp. 1008-1016, Feb. 2004.

[9] D. W. Reed, S. Freeman, L. M. Petzke, and Y. Fujita, "Quantification of Ammonia Oxidizing Bacteria in Groundwater Treated With Urea to Promote Calcite Precipitation," poster presented at the 2005 International Symposia for Subsurface Microbiology and Environmental Biogeochemistry, August 14th-19th, 2005, Jackson Hole, Wyoming, USA.

[10] "BLAST Database (Basic Local Alignment Search Tool)", Online document, Version BLAST 2.2.11 released, National Center for Biotechnology Information, National Library of Medicine, and National Institutes of Health. http://www.ncbi. nlm.nih.gov/BLAST/

[11] F. von Wintzingerode, U. B. Gobel, and E. Stackebrandt, "Determination of microbal diversity in environmental samples: Pitfalls of PCR-based rRNA analysis", in FEMS Microbiology Reviews, Vol. 21, pp. 213-229, November 1997. 